Nellemann, C., E. Corcoran (eds). 2010. Dead Planet, Living Planet - Biodiversity and Ecosystem Restoration for Sustainable Development. A Rapid Response Assessment. United Nations Environment Programme, GRID-Arendal. www. grida.no

ISBN: 978-82-7701-083-0

Printed by Birkeland Trykkeri AS, Norway

\section{Disclaimer}

The contents of this report do not necessarily reflect the views or policies of UNEP or contributory organisations. The designations employed and the presentations do not imply the expressions of any opinion whatsoever on the part of UNEP or contributory organisations concerning the legal status of any country, territory, city, company or area or its authority, or concerning the delimitation of its frontiers or boundaries.

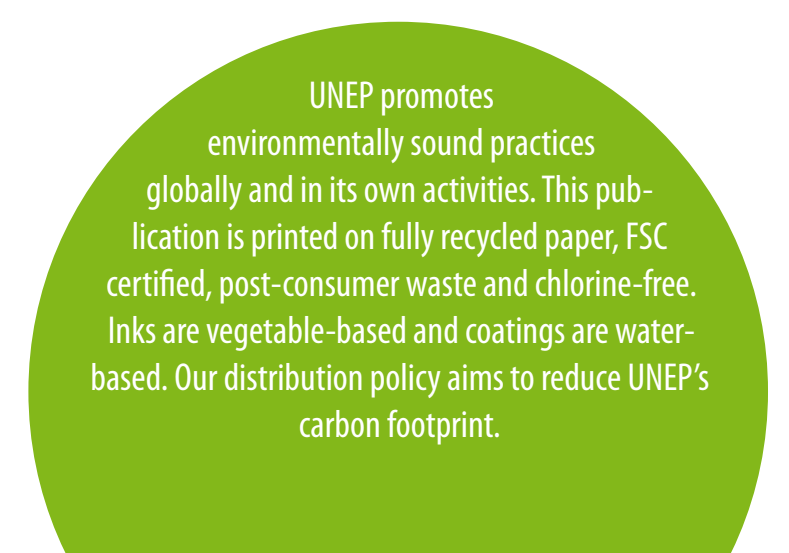



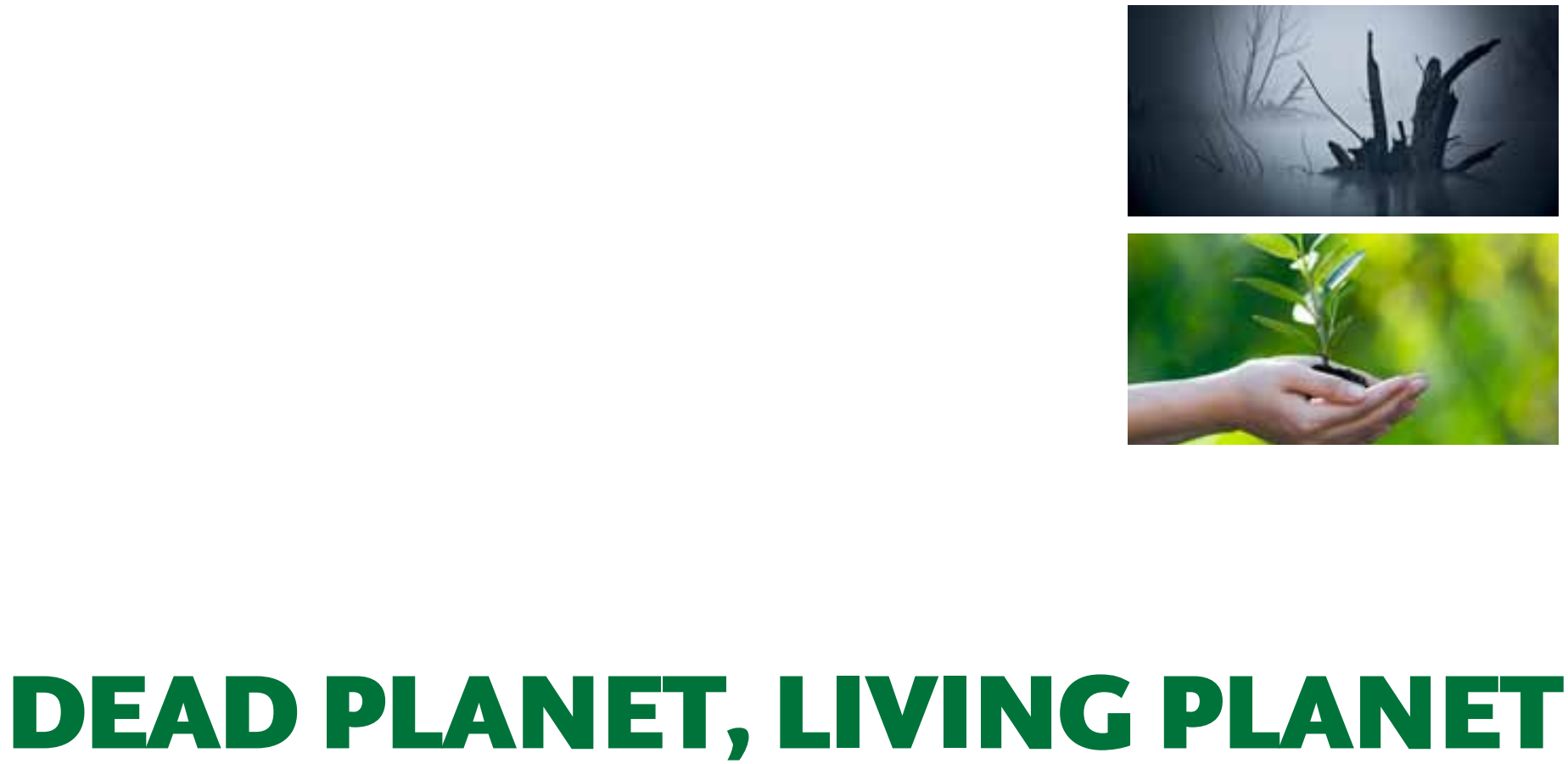
BIODIVERSITY AND ECOSYSTEM RESTORATION FOR SUSTAINABLE DEVELOPMENT

A RAPID RESPONSE ASSESSMENT

Christian Nellemann (Editor in chief) Emily Corcoran 


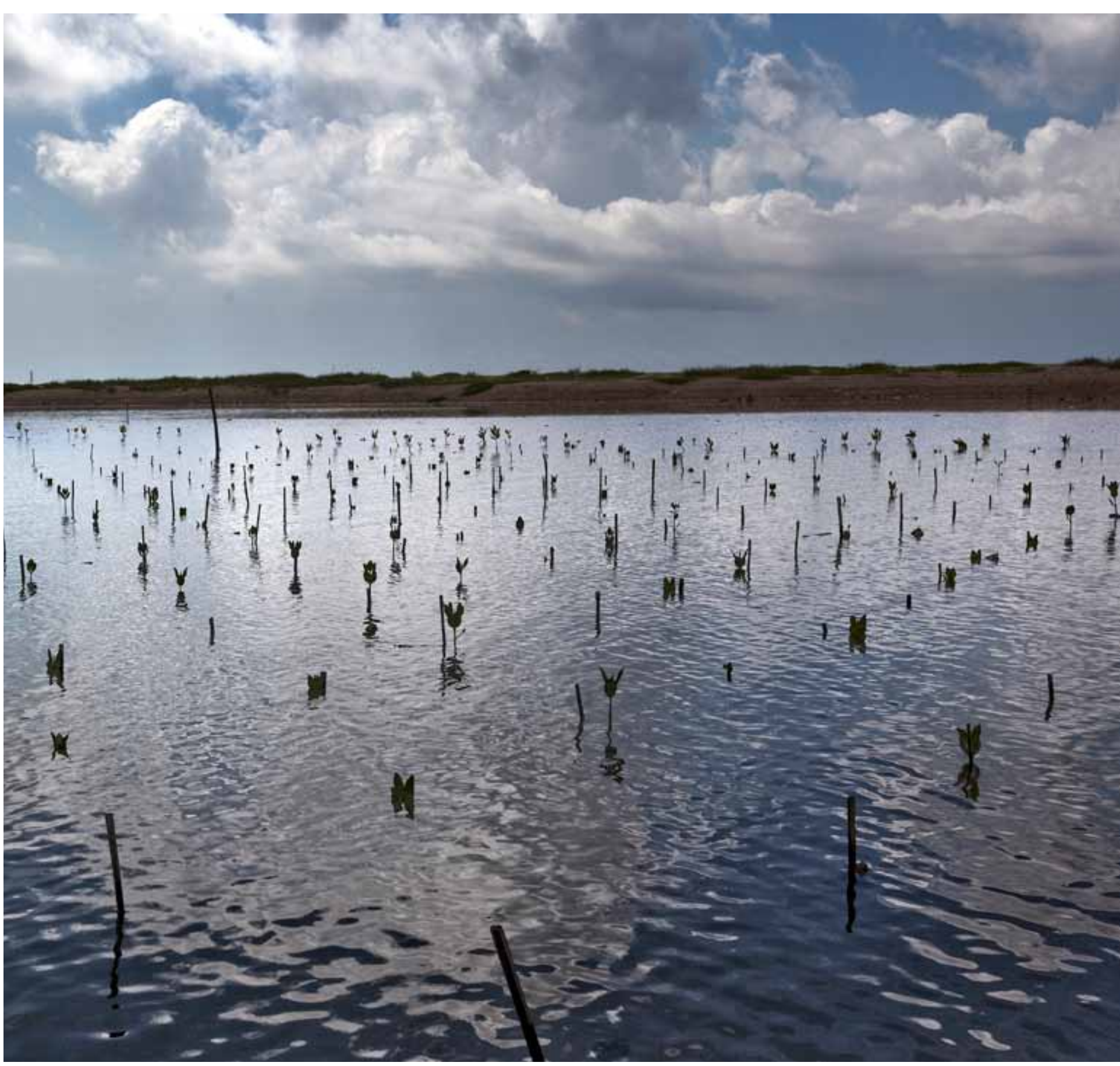




\section{Ecosystems, from forests and freshwater to coral reefs and soils, deliver essential services to humankind estimated to be worth over USD 72 trillion a year - comparable to World Gross National Income. Yet in 20I0, nearly two-thirds of the globe's ecosystems are con- sidered degraded as a result of damage, mismanagement and a failure to invest and re- invest in their productivity, health and sustainability.}

The loss of ecosystems and the biodiversity underpinning them is a challenge to us all. But a particular challenge for the world's poor and thus for the attainment of the UN's Millennium Development Goals.

Wetlands provide services of near USD 7 trillion every year. Forested wetlands treat more wastewater per unit of energy and have up to 22 fold higher cost-benefit ratios than traditional sand filtration in treatment plants. Many of the world's key crops such as coffee, tea and mangoes are dependent on the pollination and pest control services of birds and insects. By some estimates projected loss of ecosystem services could lead to up to $25 \%$ loss in the world's food production by 2050 increasing the risks of hunger. The loss of mangroves, wetlands and forests increases vulnerability and is a contributory factor as to why as many as 270 million people annually are being affected by natural disasters. Ecosystems, such as sea-grasses; tidal marshes and tropical forests, are also important in removing greenhouse gases from the atmosphere: their steady decline may accelerate climate change and aggravate further countries and communities' vulnerability to its impacts.

It is high time that governments systematically factored not only ecosystem management but also restoration into national and regional development plans.

This report is a contribution to the UN's International Year of Biodiversity and is a complement to the UNEP-hosted Econom- ics of Ecosystems and Biodiversity (TEEB) which is bringing visibility to the wealth of the world's natural capital. It documents over 30 successful case studies referencing thousands of restoration projects ranging from deserts and rainforests to rivers and coasts. The report confirms that restoration is not only possible but can prove highly profitable in terms of public savings; returns and the broad objectives of overcoming poverty and achieving sustainability. It also provides important recommendations on how to avoid pitfalls and how to minimize risks to ensure successful restoration.

Dead planet, living planet: Biodiversity and ecosystem restoration for sustainable development is part of UNEP's evolving work on the challenges but also the inordinate opportunities from a transition to a low carbon, resource efficient Green Economy.

The ability of six billion people, rising to over nine billion by 2050, to thrive let alone survive over the coming decades will in part depend on investments in renewable energies to efficient mobility choices such as high speed rail and bus rapid transport systems. But as this report makes clear, it will equally depend on maintaining; enhancing and investing in restoring ecological infrastructure and expanding rather than squandering the planet's natural capital.

\section{Achim Steiner}

UN Under-Secretary General and UNEP Executive Director 


\section{Biodiversity and ecosystems deliver crucial services to humankind - from food security to keeping our waters clean, buffering against extreme weather, providing medicines to recreation and adding to the foundation of human culture. Together these services have been estimated to be worth over $2 \mathrm{I}-72$ trillion USD every year - comparable to the World Gross National Income of 58 trillion USD in 2008.}

Human society is however living well beyond the carrying capacity of the planet and currently over $60 \%$ of ecosystem services and their biodiversity are degrading, compromising sustainability, well being, health and security. Environmental degradation is augmenting the impact of natural disasters such as floods, droughts and flash floods affecting 270 million people annually and killing some 124,000 people worldwide every year, $85 \%$ in Asia, and is, in some cases, even a primary cause of disasters. Degrading and polluted ecosystems are also a chief component in over 900 million lacking access to safe water. Poor management of activities on land and sea is further exacerbated by changing climatic conditions. In some scenarios loss of ecosystem services are depicted to result in up to $25 \%$ loss in the world's food production by 2050 along with hunger and spread of poverty in many regions.

Restoring degraded ecosystems is a key challenge. Ecological restoration is a critical component in the application of an ecosystem approach to management. It is the process of assisting the recovery of an ecosystem that has been degraded, damaged, or destroyed. It involves attempting to re-establish the ecosystem itself as well as targeting restoration of its services, such as clean water, to humankind.

Effective conservation is the cheapest and most optimal option for securing services, costing only from tens to a few hundred USD per hectare. However, protected areas cover only $13 \%, 6 \%$ and $<\mathrm{I} \%$ of the planets land, coastal, and ocean area, respectively, and many are not under effective management. Of the remaining $80-90 \%$ of the planet, almost one-third of the world's ecosystems are already directly converted for human activities such as for agriculture and cities, and another one-third have been degraded to some extent. With such levels of degradation, it is apparent that major improvements and efforts are needed to restore and manage ecosystems also outside protected areas at a much greater scale than today. Indeed, restoration costs range from hundreds to thousands, or even hundreds of thousands of USD for every hectare restored, or over io fold that of effectively managed protected areas. These numbers, however, are dwarfed compared to the long-term estimated costs of loosing these ecosystem services.

Well planned, appropriate restoration, compared to loss of ecosystem services, may provide benefit/cost ratios of 3-75 in return of investments and an internal rate of return of $7-79 \%$, depending on the ecosystem restored and its economic context, thus providing in many cases some of the most profitable public investments including generation of jobs directly and indirectly related to an improved environment and health. Ecological restoration can further act as an engine of economy and a source of green employment.

A world wide survey of studies looking at restoration and conservation of ecosystem services shows us that conservation and restoration provides a highly profitable, low-cost investment for maintaining ecosystem services. Increases in biodiversity and ecosystem service measures after restoration are positively related. Restoration actions focused on enhancing biodiversity should support increased provision of ecosystem services, particularly in tropical terrestrial biomes. Conversely, these results suggest that ecosystem restoration focused mainly on improving services should also have a primary aim at restoring biodiversity.

Challenges of waste water management in rural areas, which produce over half of the organic contamination of waste wa- 
ter, can best be met by restoring ecosystem catchments, riparian zones and wetlands, the latter providing services of an estimated 6.62 trillion USD annually. Challenges of disaster mitigation and prevention from floods and storms are most effectively met by reducing deforestation of catchments, restoring wetlands, mangroves and coral reefs. Coastal wetlands in the US which currently provide storm protection services have been valued at 23 billion USD annually. In India, mangroves serving as storm barriers have been noted to reduce individual household damages from 153 USD/household to an average of $33 \mathrm{USD} /$ household in areas with intact mangroves.

Challenges of land degradation, erosion, overgrazing and loss of soil fertility, pollination and natural pest control can be met through more sustainable land use practices and restoration. Exotic species infestations can in many case be addressed by restoration, including re-establishing more organic based farming systems. Organic farming systems have been estimated to provide at least $25 \%$ higher ecosystems services than conventional.

Improving the health and subsequent labor productivity of people suffering from water related diseases, currently filling nearly half of the Worlds hospital beds, can in part be met through restoration of catchments and improved waste water management. Restoration of wetlands to help filter certain types of wastewater can be a highly viable solution to wastewater management challenges. Forested wetlands treat more wastewater per unit of energy and have a 6-22 fold higher benefit-cost ratio than traditional sand filtration in treatment plants. Indeed, in New York, payments to maintain water purification services in the Catskills watershed (USD I-I.5 billion) were assessed at significantly less than the estimated cost of a filtration plant (USD 6-8 billion plus USD 300-500 million/year operating costs).

Climate change mitigation and carbon sequestration can partially be met through conservation and restoration of carbon sinks such as forests, more sustainable agriculture and marine ecosystems. The proposed REDD+ (Reducing Emissions from Deforestation and Forest Degradation) could lead to an estimated halving of deforestation rates by 2030 , cutting emissions by $\mathrm{I} .5^{-2.7} \mathrm{Gt} \mathrm{CO}_{2}$ per year at a cost of USD I7.2 billion to USD 33 billion/year, but with a long term benefits estimated at USD 3.7 trillion in present value terms. At a global scale, $\mathrm{CO}_{2}$ emission from peatland drainage in Southeast Asia is contributing the equivalent of $\mathrm{I} .3 \%$ to $3 . \mathrm{I} \%$ of current global $\mathrm{CO}_{2}$ emissions from the combustion of fossil fuel. Conservation, restoration and reforestation of peatlands drained and logged for palmoil, timber or cropland are, along with restoration of mangroves and seagrass communities, important climate mitigation measures.

A set of guidelines are recommended to avoid pitfalls of restoration projects. These pitfalls include among others I) Unrealistic goals or changes in restoration targets in the process; 2) Improper and partial restoration which creates monocultures with little ecosystem service capacity compared to reference sites; 3 ) Un-intended transplant of non-native invasive pests or species; 4) Lack of monitoring to ensure that restoration results in rising biodiversity and services in restored ecosystems; 5) Lack of reduction in the pressures that lead to the loss of ecosystems in the first place; 5) Lack of adequate integration of stakeholders and socio-economic issues.

However, as long as these pitfalls are given adequate attention, evidence from a diversity of ecosystem restoration projects across the world reveal positive results, typically restoring $25-44 \%$ of the original services and biodiversity provided in comparable ecosystems. Restoration can therefore together with conservation clearly improve damaged or previously lost ecosystem services with major positive effects on primary development goals in nations worldwide.

Surveys of user and public attitudes also reveal high payment willingness and public support to restoration projects. Restoration should therefore be considered an important component and in some cases partial solution to major societal challenges of development including poverty alleviation, labor productivity, generation of jobs and prosperity, health and disaster mitigation and prevention. 
1) Prioritize to protect biodiversity and ecosystem service hotspots, even when partially degraded, to halt further degradation and allow for restoration planning to commence. Conservation, within the context of spatial planning, provides by far the most cost efficient way to secure ecosystem services. This is particularly critical for areas with high degree of land pressures and development.

2) Ensure that investments in restoration are combined with long-term ecosystem management in both restored and in surrounding areas to ensure gradual recovery. Overseas Development Agencies, International finance agencies and other funders including regional development banks and bilateral agencies should factor ecosystem restoration into development support; job generation and poverty alleviation funding.

3) Infrastructure projects that damage an ecosystem should set aside funds to restore a similar degraded ecosystem elsewhere in a country or community. Payments for Ecosystem Services should include a proportion of the payment for the restoration and rehabilitation of damaged and degraded ecosystems. One percent of GDP should be considered a target for investments in conservation and restoration.

4) Apply a multidisciplinary approach across stakeholders in order to make restoration investments successful. Wise investments reduce future costs and future public expenses, but it is imperative that the driving forces and pressures behind the initial degradation are addressed in order to secure progressive recovery and that local stakeholders become involved and benefit from the restoration process.

5) Ensure that restoration projects take into account the changing world: Ecosystem restoration should be implemented in consideration of scenarios for change in a continually changing world, including climate change and land pressures. Changes in surrounding areas or in the prevailing environmental conditions will influence both the rate of recovery and ultimate restoration success.

6) Restoration needs to address a range of scales from intense hotspot restoration to large-scale restoration to meet regional changes in land degradation. Degree of biodiversity restored is often linked to quality of services obtained and is intrinsically linked to successful outcome.

7) Ensure that ecosystem restoration is implemented, guided by experiences learned to date, to ensure that this tool is used appropriately and without unexpected consequences, such as the unintended introduction of invasive species and pests and sudden abandonment of restoration targets in the process.

8) Apply ecosystem restoration as an active policy option for addressing challenges of health, water supply and quality and wastewater management by improving watersheds and wetlands, enhancing natural filtration.

9) Apply ecosystem restoration as an active policy option for disaster prevention and mitigation from floods, tsunamis, storms or drought. Coral reefs, mangroves, wetlands, catchment forests and vegetation, marshes and natural riparian vegetation provide some of the most efficient flood and storm mitigation systems available and restoration of these ecosystems should be a primary incentive in flood risk and disaster mitigation planning.

10) Enhance further use of ecosystem restoration as a mean for carbon sequestration, adaptation to and mitigation of climate change. The restoration targets for sequestration includes among other forests, wetlands, marine ecosystems such as mangroves, seagrasses and salt marshes, and other land use practices. 
11) Improve food security through ecosystem restoration. Given the significance of food production and its relations to biodiversity and ecosystems loss, expanded recommendations are presented:

a. Strengthen natural pest control: Restoration of field edges, crop diversity and wild crop relatives, forests and wetlands is a tool for improving natural weed, pest and disease control in agricultural production. This should be combined with biological control including establishment and facilitation of natural predator host plants and insects, enzymes, mites or natural pathogens.

b. Improve and restore soil fertility: Research and Development funds into agriculture should become a primary investment source for financing restoration of lost and degraded soils, improve soil fertility and water catchment capacity, by investing in small-scale eco-agricultural, agro-forestry- and intercropping systems

c. Support more diversified and resilient agricultural systems that provide critical ecosystem services (water supply and regulation, habitat for wild plants and animals, genetic diversity, pollination, pest control, climate regulation), as well as adequate food to meet local and consumer needs. This includes managing extreme rainfall and using inter-cropping to minimize dependency on external inputs like artificial fertilizers, pesticides and blue irrigation water. Support should also be provided for the development and implementation of green technology for small-scale farmers.

d. Improve irrigation systems and reduce evapo-transpiration in intercropping and green technology irrigation or rainfall capture systems.

e. Improve water supply and quality and wastewater management in rural, peri-urban, and urban areas through restoration of field edges, riparian zones, forest cover in catchments, extent of green areas and wetland restoration.
5 PREFACE

6 SUMMARY

11 INTRODUCTION - ECOSYSTEM SERVICES

17 GLOBAL LANDUSE CHANGE AND SCENARIOS OF BIODIVERSITY LOSS

21 ECOSYSTEM RESTORATION FOR BIODIVERSITY CONSERVATION

24 A FOCUS ON FORESTS

37 ECOSYSTEM RESTORATION FOR WATER SUPPLY

43 ECOSYSTEM RESTORATION FOR HEALTH AND WASTE WATER MANAGEMENT

51 ECOSYSTEM RESTORATION FOR FOOD SECURITY

59 ECOSYSTEM RESTORATION FOR CLIMATE CHANGE MITIGATION

69 ECOSYSTEM RESTORATION FOR DISASTER PREVENTION AND MITIGATION

73 THE FINANCIAL BENEFITS OF ECOSYSTEM RESTORATION - GREEN ECONOMY

78 RESTORATION AND RECOVERY OF ERODED AND OVERGRAZED ARID GRASS AND SHRUBLANDS

82 ECOSYSTEM RESTORATION AND REHABILITATION LESSONS LEARNT

90 RESTORATION OF A DEPLETED CRAYFISH FISHERY IN EUROPE - LESSONS LEARNT

95 CONCLUSIONS AND RECOMMENDATIONS

98 GLOSSARY

99 ACRONYMS

100 CONTRIBUTORS

102 REFERENCES 


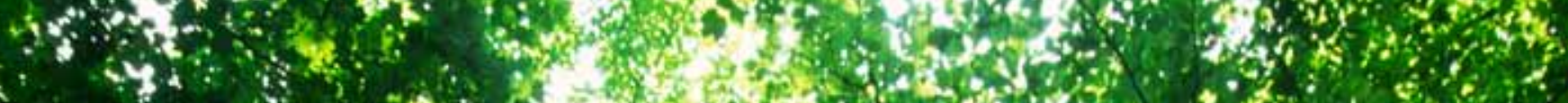

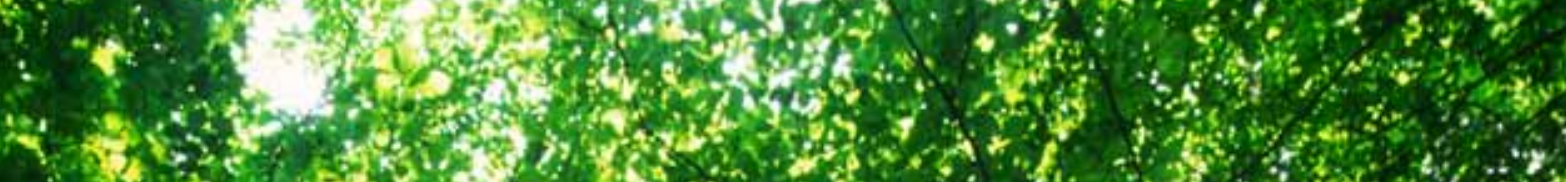

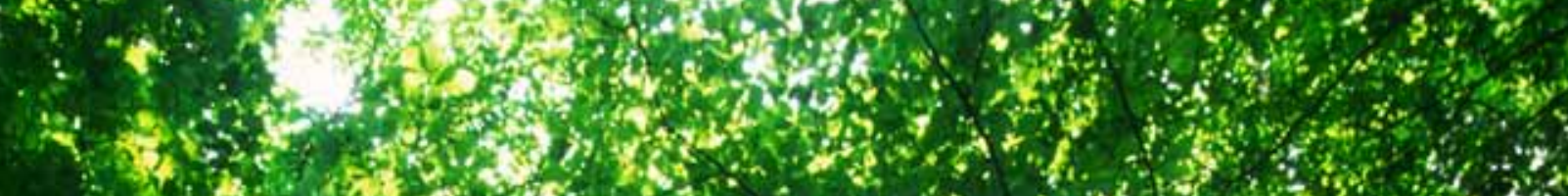
$\because 2 \%$ ond

s.

is

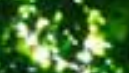

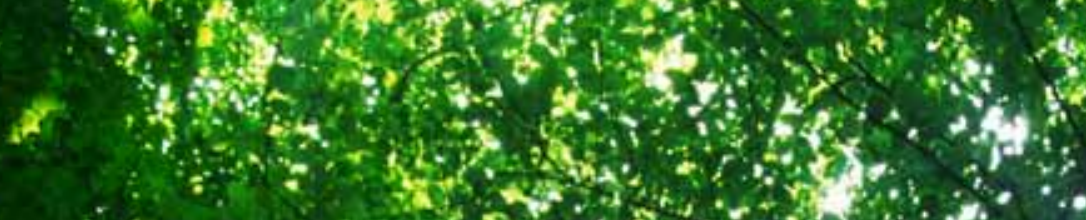

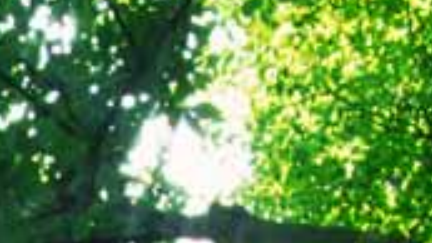

. 340

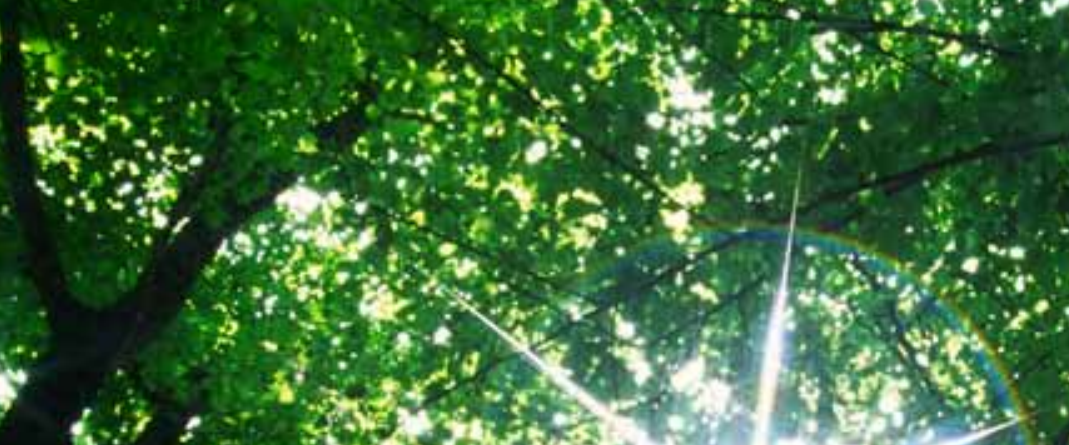

ats

(2)

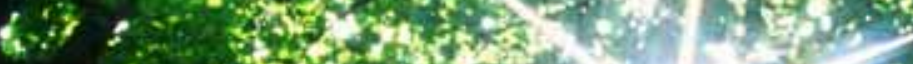

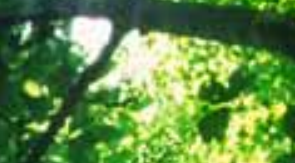

1.6.

s.

$+3, \infty$ - 3

8

* 18

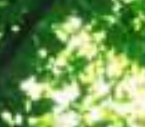

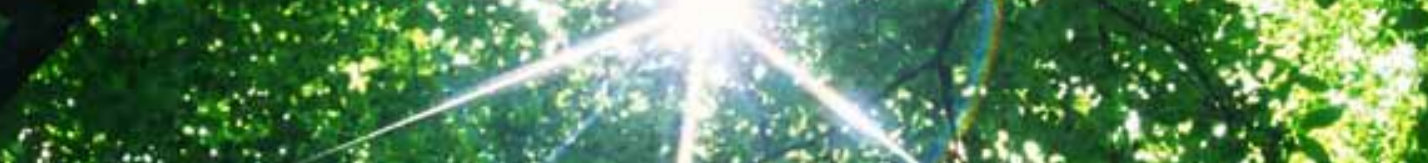

3

sotes

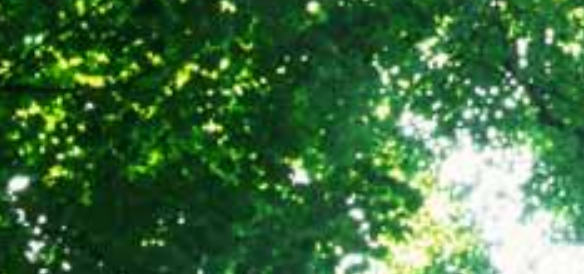

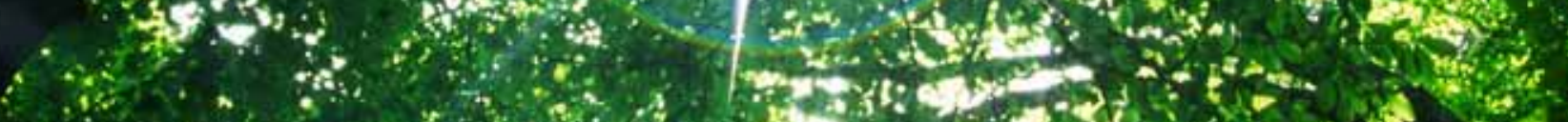

$x^{2}$

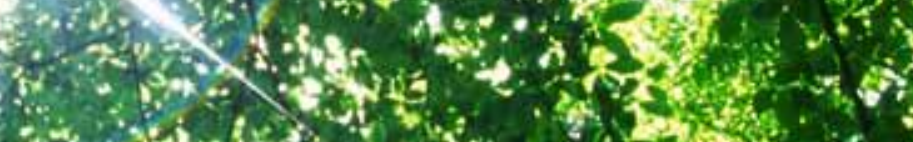

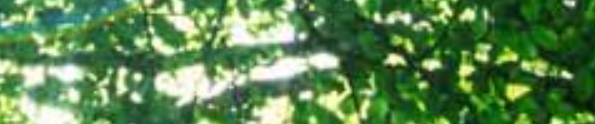

M.

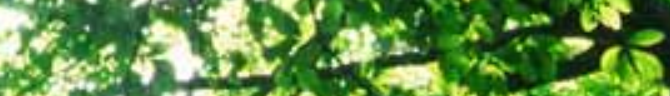

$x+5$
$+\infty$

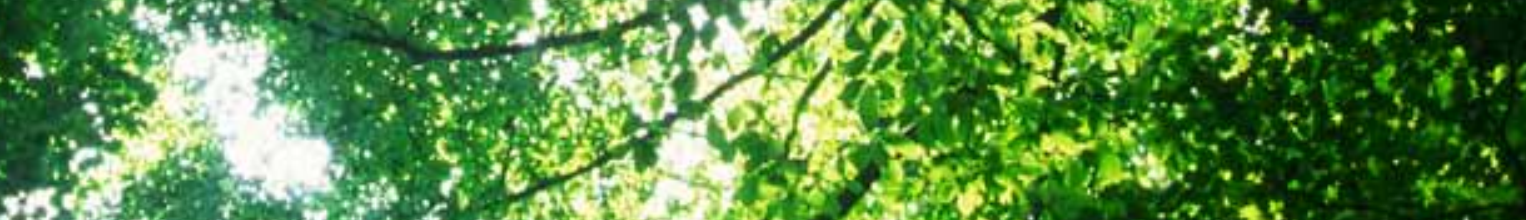

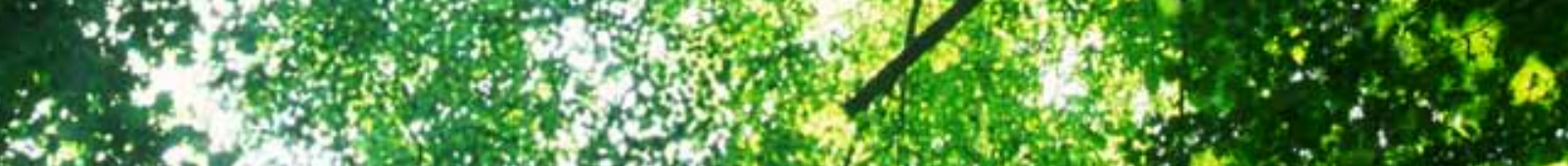

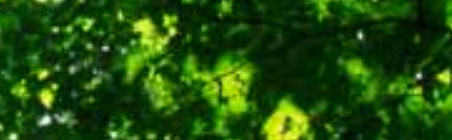

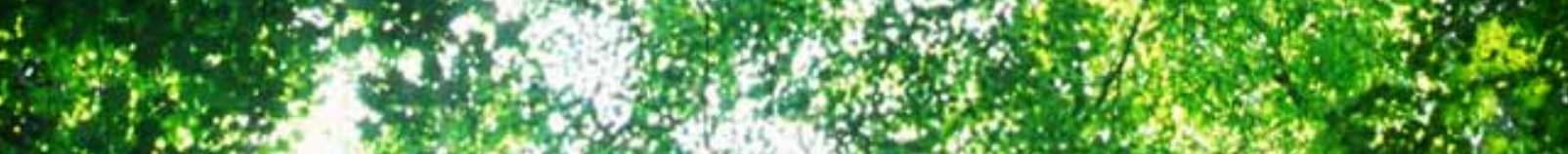
1.062

.

$42,7, x, 2,8 x$ $x^{3}$

사 $x$ the

$x^{-4}+8$ - $x$ 
Ecosystems and our natural environment constitute the platform upon which our entire existence is based (Costanza et al., I997). The services on which we depend include not only the air that we breathe and the joy of wildlife, but form the very basis of our food production, freshwater supply, natural filtering of pollution, buffers against pests and diseases and buffers against disasters such as floods, hurricanes and tsunamis. The MA (2005) described four catagories of services, provisioning, regulating, supporting and cultural.

An Ecosystem is the dynamic complex of plant, animal and micro-organism communities and the nonliving environment interacting as a functional unit. It assumes that people are an integral part of ecosystems (MA, 2005). Ecosystem Services are the benefits that people obtain from ecosystems. They can be described as provisioning services (e.g. food, water, timber); regulating services (e.g. regulation of climate, floods, disease, waste and water quality); cultural services (e.g. recreational, aesthetic and spiritual) and supporting services (e.g. soil formation, photosynthesis and nutrient cycling) (MA, 2005).

Ecosystems ensure pollination, so crucial for agricultural production (Allenwardell et al., et al., I998; Brown and Paxton, 2009; Jaffe et al., 2010), estimated at I53 billion USD in 2005 (Gallai et al., 2009) and it includes supply of water not only for irrigation and household use, but also for cooling in industrial processes, dilution of toxic substances and a transportation route (UNEP, 20IO). It is also critical to health, not only through water supply and quality and through natural filtering of wastewater (UNEP, 20IO). $80 \%$ of people in developing countries rely on traditional plant-based medicines for basic healthcare (Farnsworth et al., I985) and three-quarters of the world's top-selling prescription drugs include ingredients derived from plant extracts" (Masood, 2005), providing a string of services from rich to poor alike, but with particular value to the impoverished (Sodhi et al., 20I0; UNEP, 2009).

Pest control is another key ecosystem service underpinned by biodiversity; it seems to be greatly determined by the abun-

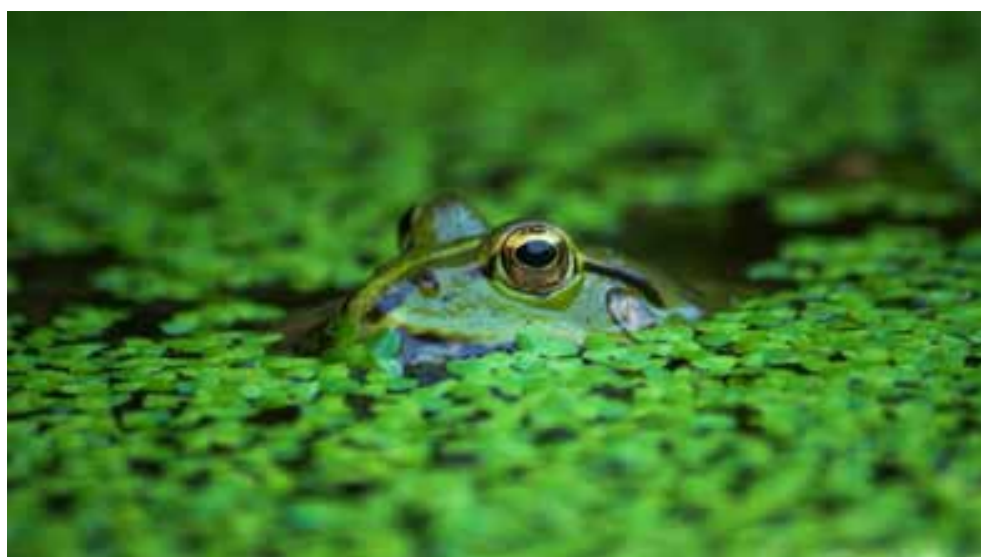

dance of natural enemies present to counter the pest species involved, such as in coffee production (Batchelor et al., 2005; Johnson et al., 2010). Although biological systems are complex, improved pest control is often founded on a diversity of natural predators, and non-crop habitats are fundamental for the survival and presence of these biological control agents (predators, parasitoids) (Zhang et al. 2007). Landscape diversity or complexity, and proximity to semi-natural habitats tends to produce a greater abundance and species richness of natural enemies (Balmford et al. 2008, Bianchi et al. 2006; Kremen \& ChaplinKramer 2007; Tscharntke et al. 2007).

Global change will alter the supply of ecosystem services that are vital for human well-being (Schröter et al., 2005). Without 


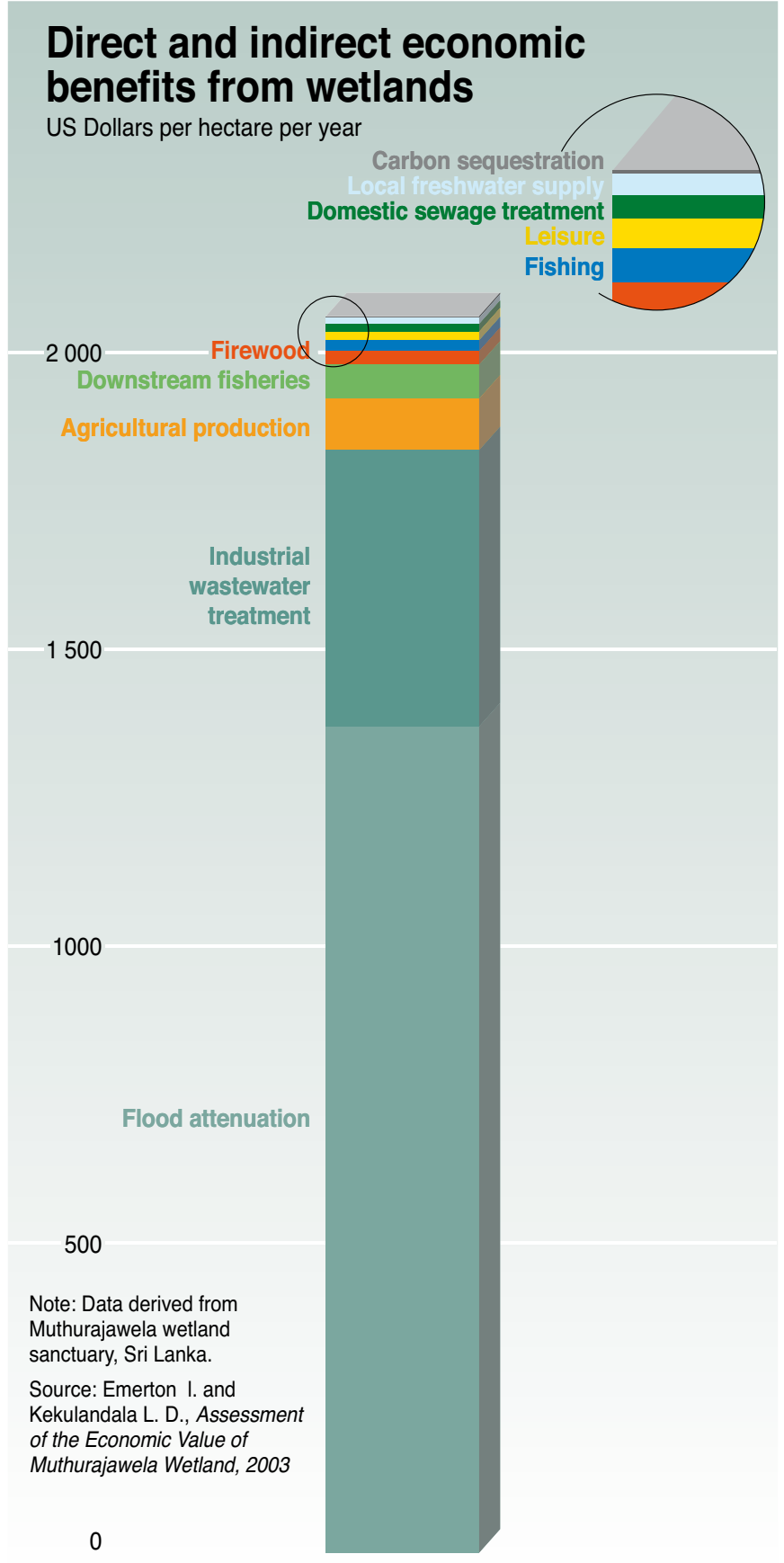

Figure 1: Benefits from wetlands.

\section{Why is ecosystem restoration needed?}

As ecosystems are removed or degraded through acute one off events, or more often as a result of chronic contamination, degradation from development and other human activities - not only does this lead to direct costs over time but also to problems such as lowered productivity, food insexurity and health problems, thus threatening sustainable development.

functioning natural ecosystems, water supply for the world's food production would collapse, not only causing economic collapse and crisis in the entire financial system, it would also endanger health and lives of billions, and, hence, ultimately our survival (UNEP, 2009). The economic value of these ecosystem services were estimated at $\mathrm{I} 6-54$ trillion USD annually already in 1997 or corresponding to ca. 2I-72 trillion USD in 2008 (CPI/inflation adjusted) compared to an estimated World Gross National Income (Atlas method, Worldbank) in 2008 of 58 trillion USD (Costanza et al., I997). (N.B. Please note that there is substatial uncertainty with regard to these numbers. Updated figures are expected to be available by $2010 / \mathrm{II})$.

At the same time, almost one third of the worlds ecosystems has been transformed or destroyed, and another third heavily fragmented and disturbed, and the last third already suffering from invasive species and pollution (UNEP, 200I; www.globio.info). Over $60 \%$ of the ecosystems services are considered degraded (MA, 2005). The big five human threats to the environment in the form of I) habitat loss and fragmentation; 2) unsustainable harvest; 3) pollution; 4) climate change; and 5) introduction of exotic invasive species, are combined or individually rapidly not only destroying and degrading our ecosystems, they are also depleting and ruining the very services from them upon which we base our health and prosperity.

It is the vast and rapid loss of these ecosystems, and our dependence on these services, that require us to consider their restoration and rehabilitation. In this report, UNEP together with partners address the ultimate challenge to sustainable development, namely ensuring that ecosystems will continue to support human prosperity and well-being on a diverse planet.

The objective of this report is to provide an overview of some of the most crucial services rendered by natural ecosystems to humankind and how they can be restored as part of policy development to partially resolve key challenges of water, health, 


\section{Ecosystem connectivity and impacts on ecosystem services from human activities}
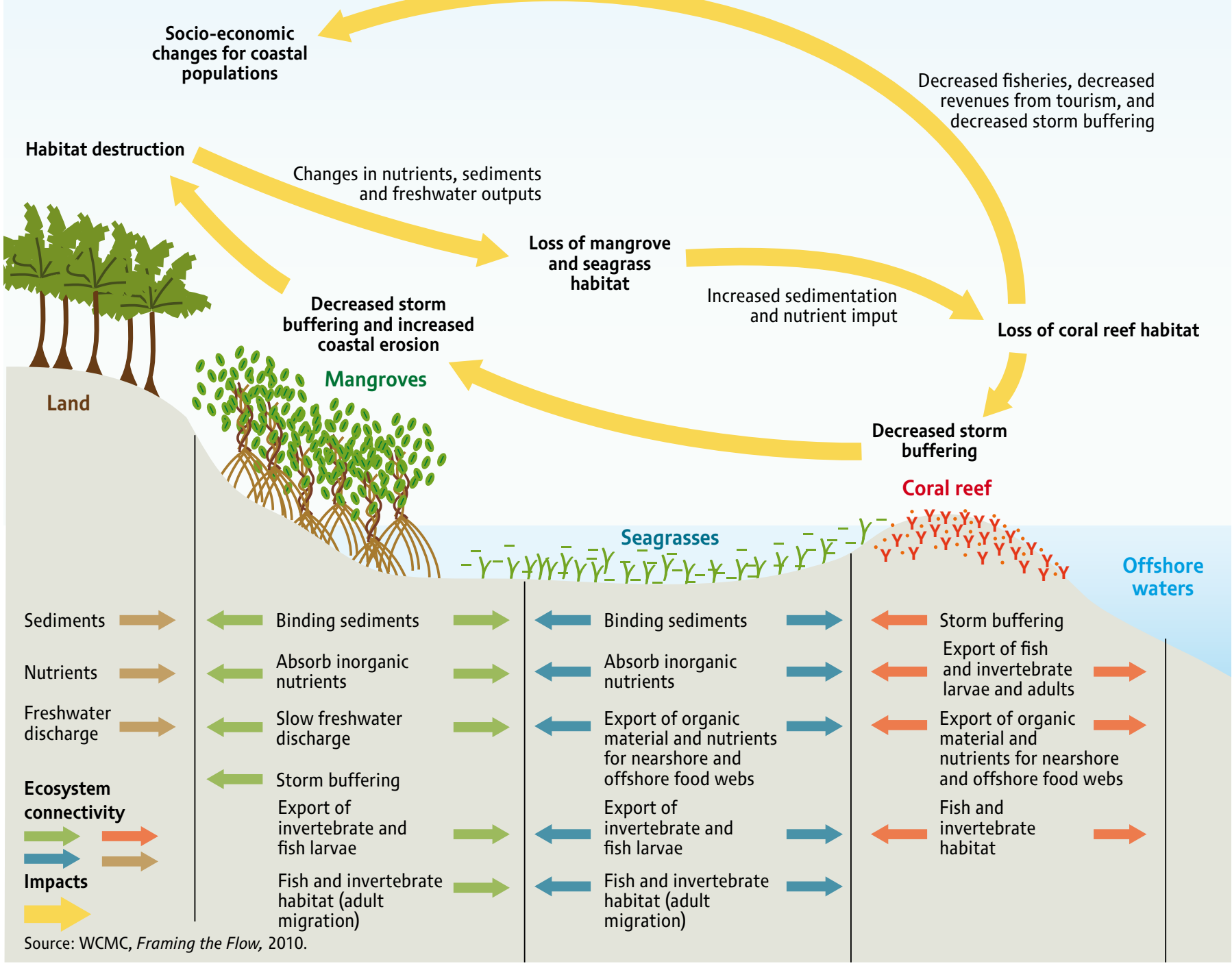

Figure 2: Ecosystem connectivity and impacts on ecosystem services from human activities.

environment, food security and disaster mitigation. It also addresses the key financial benefits involved in conservation, ecosystem restoration or ultimate loss of ecosystems and their role in sustainable development. This includes not only the com- plexities of ecological restoration, but also the importance of integrating the multistaker community involved, influencing and influenced by the initial degradation and in the benefits of restoration (Brander et al., 2006; Granek et al., 2010). 


\section{Corta Alloza and Utrillas coal mine restoration, Spain}

Before (1995, top) and after (2005, bottom) restoration views of surface coal mine Corta Alloza (Andorra, Teruel, NE Spain). An ecosystem restoration approach was applied to this case to reestablish the connectivity between terrestrial and aquatic habitats and to provide ecossytems services for the human populations living in the municipality.

Project and photos credit: Endesa S.A. \& Francisco A. Comin, Instituto Pirenaico de Ecologia-CSIC
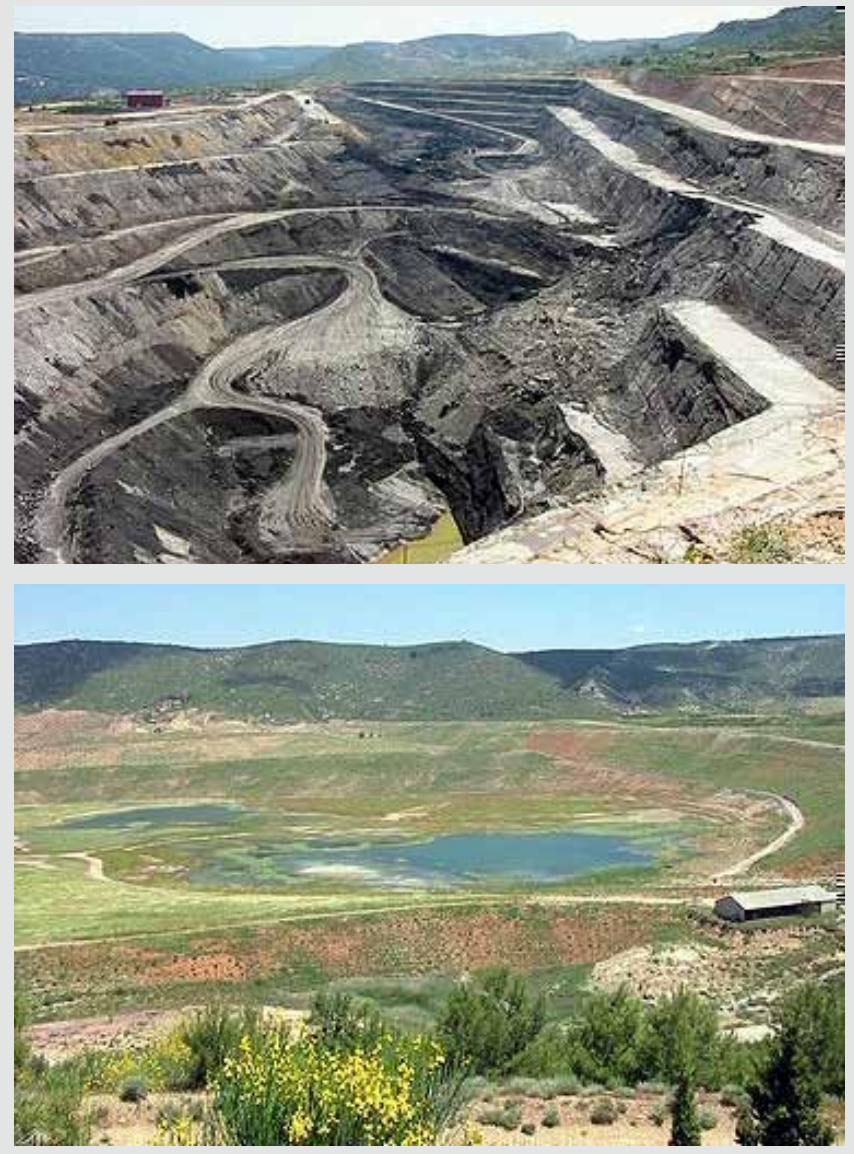

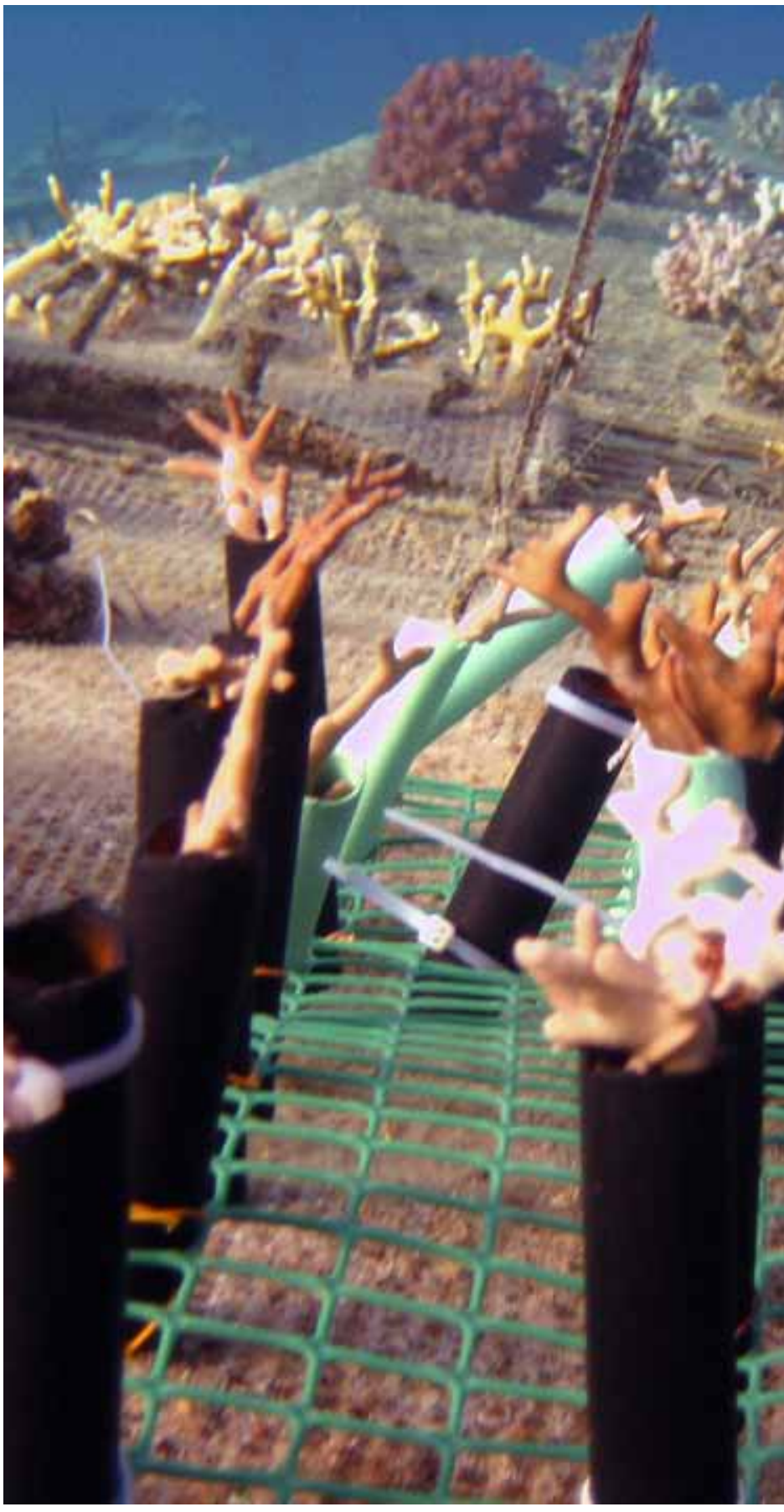




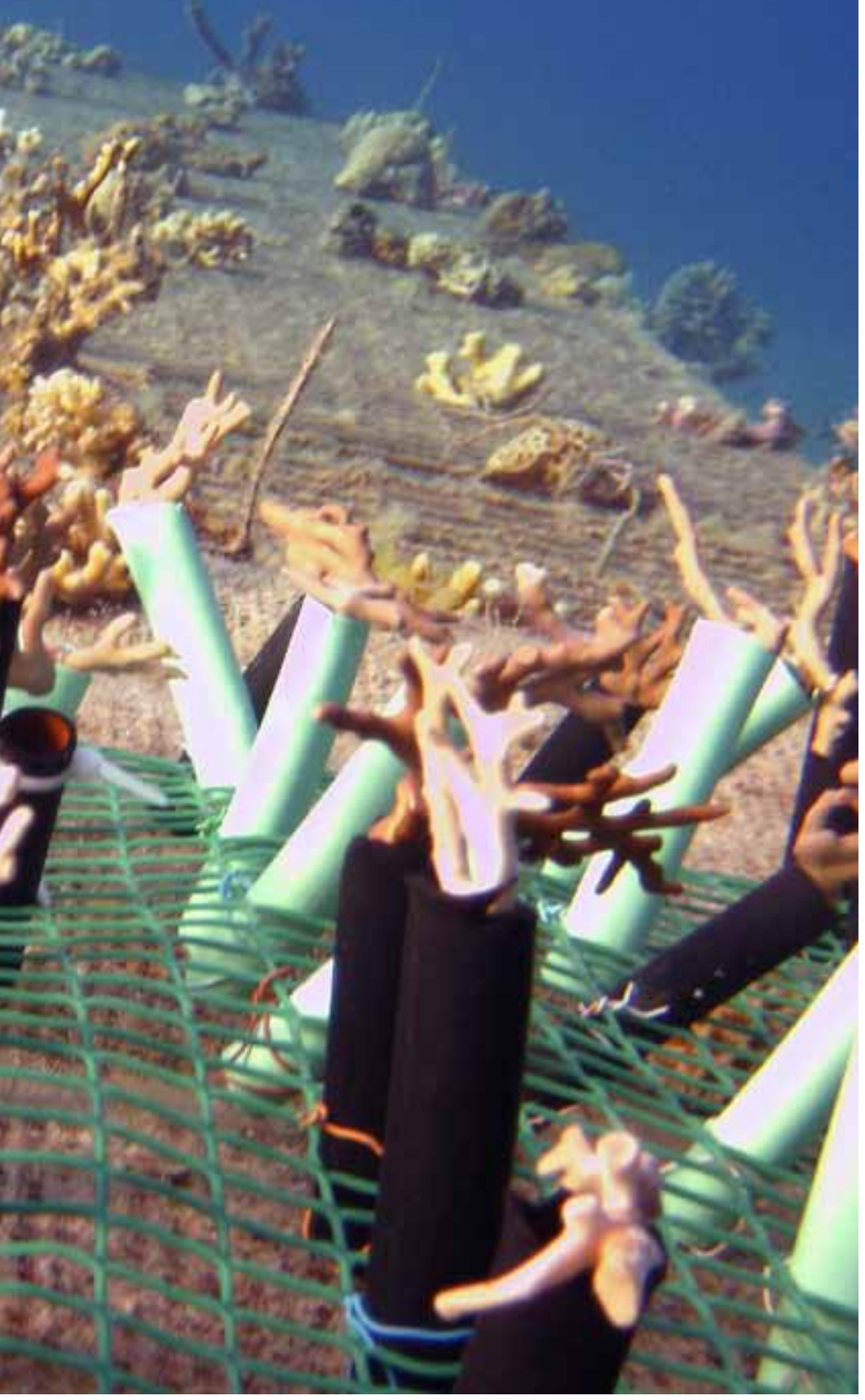

What is ecosystem restoration?

Restoration can be defined as re-establishing the presumed structure, productivity and species diversity that was originally present at a site that has been degraded, damaged or destroyed. In time, the ecological processes and functions of the restored habitat will closely match those of the original* habitat (SER, 2004; FAO, 2005).

The concept of landscape restoration tackles the broader range of issues and needs via a landscape-scale approach, "a planned process that aims to regain ecological integrity and enhance human wellbeing in deforested or degraded landscapes" (WWF International 2007).

Reclamation aims to recover productivity (but little of the original biodiversity) at a degraded site. In time, the protective function and many of the original* ecological services may be re-established. Reclamation is often done with exotic species but may also involve native species. (WWF/IUCN 2000)

The objective of rehabilitation is to re-establish the productivity and some, but not necessarily all, of the plant and animal species thought to be originally* present at a site. (For ecological or economic reasons the new habitat might also include species not originally present at the site). In time, the protective function and many of the ecological services of the original habitat may be re-established (FAO 2005).

Regeneration is often viewed as the growth or re-emergence of the native species in a place after it has been destroyed or degraded, resulting from the protection of an area from biotic interference. Regeneration may come about naturally or result from human intervention (CFIOR websites).

Recovery of a habitat is linked to the ecological succession of a site. That is the site returning naturally to the state it had been before it had been degraded or destroyed without any intervention from humans (CFIOR websites).

* While restoration-related definitions often focus on 'original' habitat cover, it may be more appropriate in the future to focus on restoring resilient natural habitats, for example through paying attention to connectivity and dispersal, rather than assuming that all 'original' species will persist under changed conditions. From this point of view, 'potential' would be substituted for 'original' in the above definitions. 


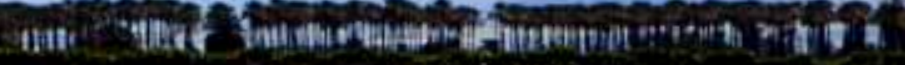

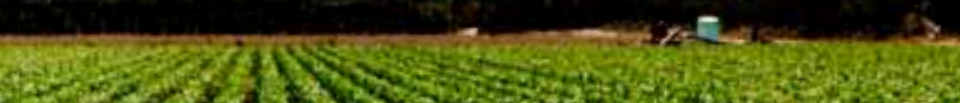

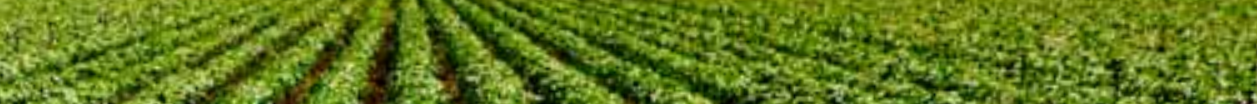

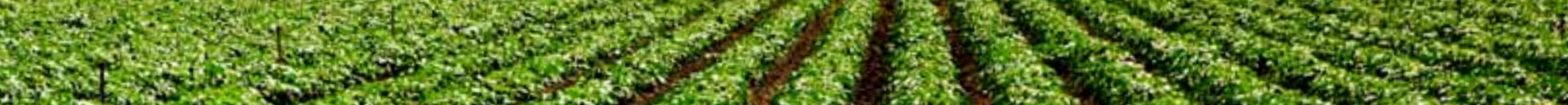

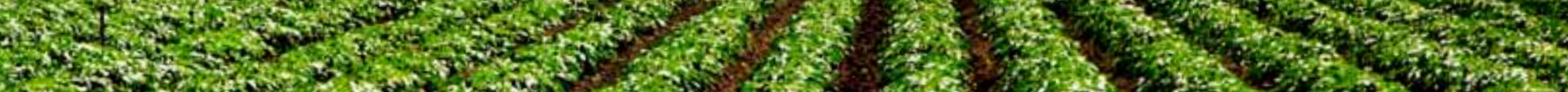

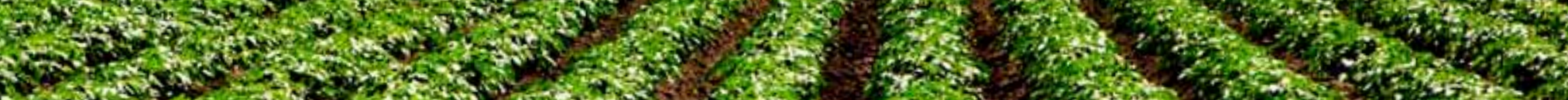

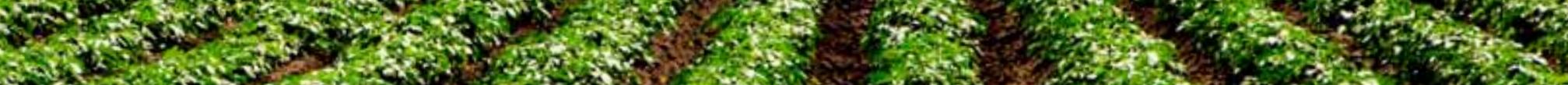

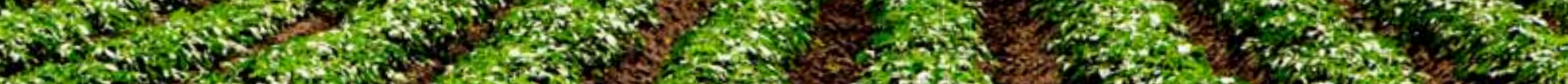

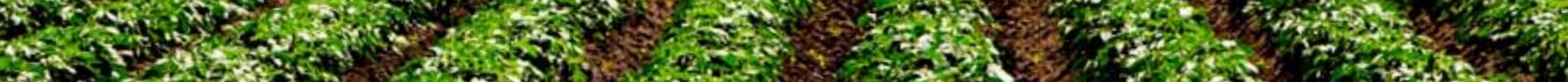

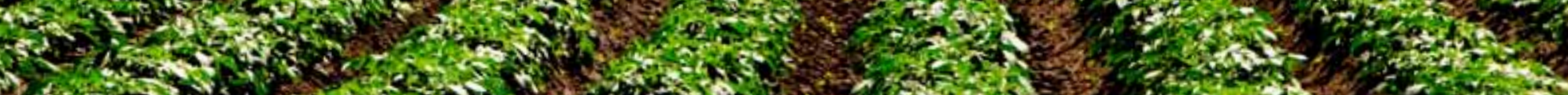

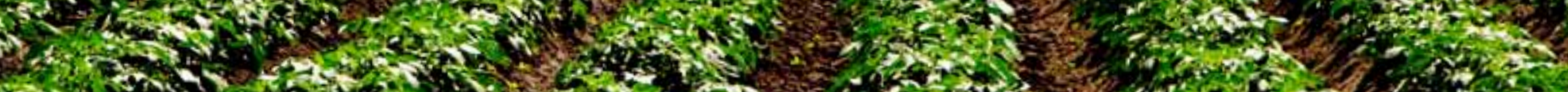
S. Notion Hon

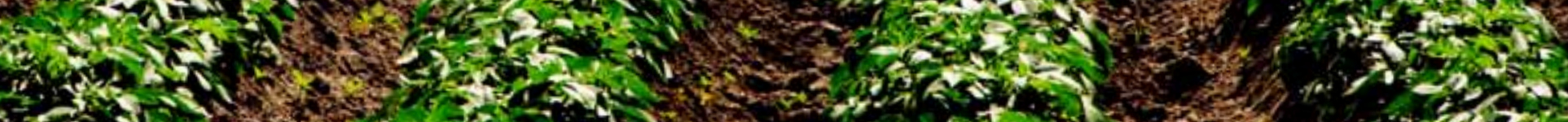
(1)

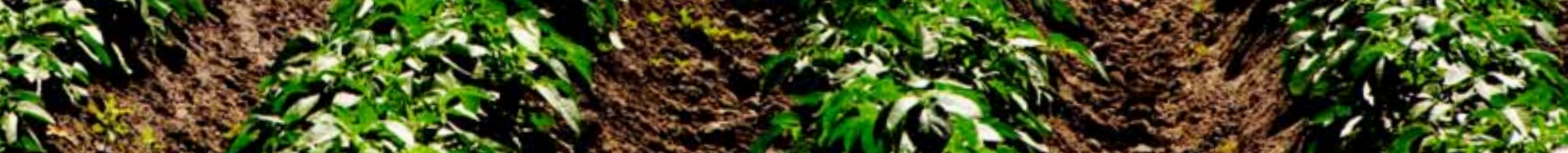

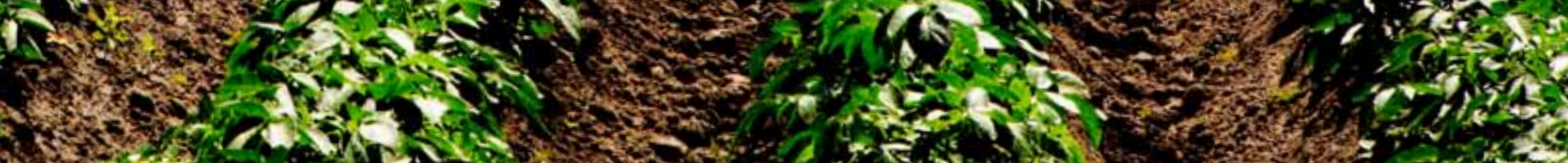

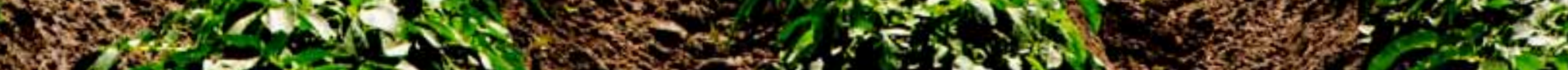

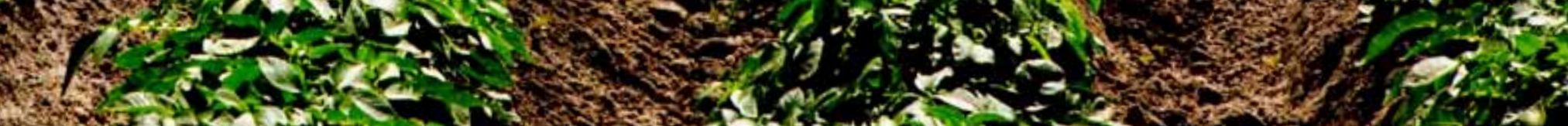

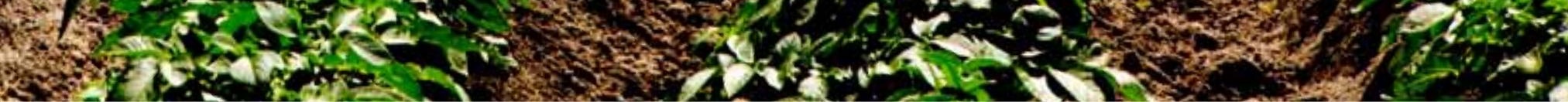




\section{GLOBAL LANDUSE CHANGE AND SCENARIOS OF BIODIVERSITY LOSS}

Modern agricultural methods and technologies brought spectacular increases in food production, but are also a primary cause of habitat loss and ecosystem destruction (Tilman et al., 2002). Clearance for cropland or permanent pasture has already reduced the extent of natural habitats on agriculturally usable land by more than $50 \%$ (Green et al 2005), and much of the rest has been altered by temporary grazing (Groombridge and Jenkins, 2002). Habitat modification already affects more than $80 \%$ of globally threatened mammals, birds and plants (Groombridge and Jenkins, 2002), with implications for ecosystem services and human well-being. Of the world's land, cosatal and ocean area, only $13 \%, 6 \%$ and less than I\%, respectively, are within protcted areas (WDPA, 20I0).

\begin{abstract}
Despite its crucial role for providing ecosystem services agriculture remains the largest driver of genetic erosion, species loss and conversion of natural habitats (MA, 2005). Globally over 4,000 assessed plant and animal species are threatened by agricultural intensification (IUCN, 2008). A central component in avoiding loss of biodiversity and ecosystem services, such as water, from expanding agricultural production and resource extraction is to limit the trade-off between economic growth and biodiversity by stimulating to agricultural productivity and more efficient land use.
\end{abstract}

Most global scenarios project increased use of land for arable crops and grazing. Scenarios from the Global Environmental Outlook, The Millennium Assessment and the Global Biodiversity Outlook all show increases of land use as a result of a growing population and increased economic development.

Further enhancement of agricultural productivity ('closing the yield gap') and reduction of post harvest losses are key factors in reducing the increased need for land and, consequently, the rate of biodiversity loss (CBD, 2008). These options should be implemented carefully in order not to cause new undesired negative effects, such as emissions of nutrients and pesticides, as well as risks of land degradation. An increase in protected areas and change towards more eco-agricultural cropping systems and sustainable meat production could have immediate positive effects on both biodiversity and water resource management, while increasing revenues from tourism.

A reduction of crop- and pasture land can only be achieved if drastic changes in diets are assumed. Some of these more extreme scenarios are presented by Wise et al. (2009) and Stehfest et al., (2009). They suggest that if enhanced agricultural productivity is assumed and the consumption of meat is greatly reduced then large areas will become available for forest and natural grassland recovery. Some scenarios also predict a shift of agricultural production towards different regions, resulting in a reduction of agricultural land in, for example, Europe. Recovery of biodiversity is possible on abandoned land, but the rate and quality depend on actions taken on these lands. In models like GLOBIO this factor is not yet incorporated at this stage. Autonomous recovery is a slow process and is represented by the land use category 'secondary forest' in GLOBIO (Alkemade et al., 2009). Restoration activities for example plantations may speed up the recovery process, but are not included in the GLOBIO model. 


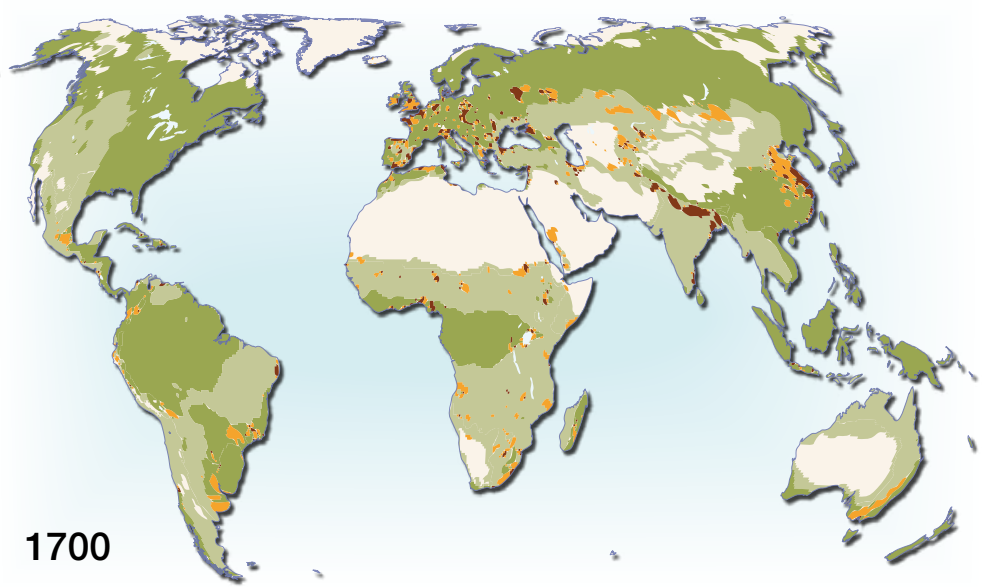

\section{Landuse and agriculture}

\section{Agricultural land}

Extensive grasslands (incl pasture)

Regrowth after use

\section{Forests}

Grasslands

$\downarrow$ Non-productive land

Figure 3: Projected landuse changes 17002050. Loss of biodiversity with continued agricultural expansion, pollution, climate change and infrastructure development (GLOBIO) (Alkemade et al., 2009)
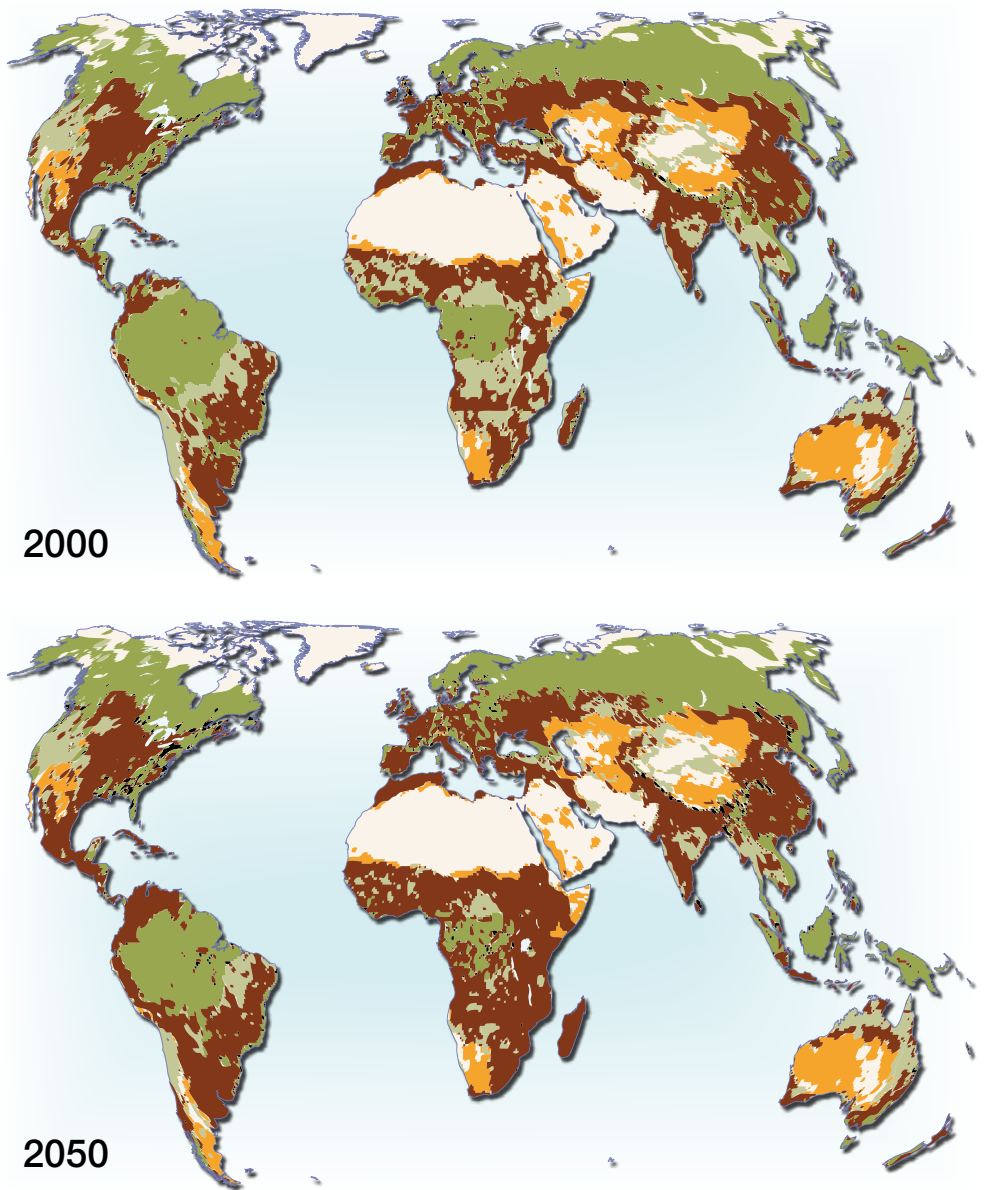

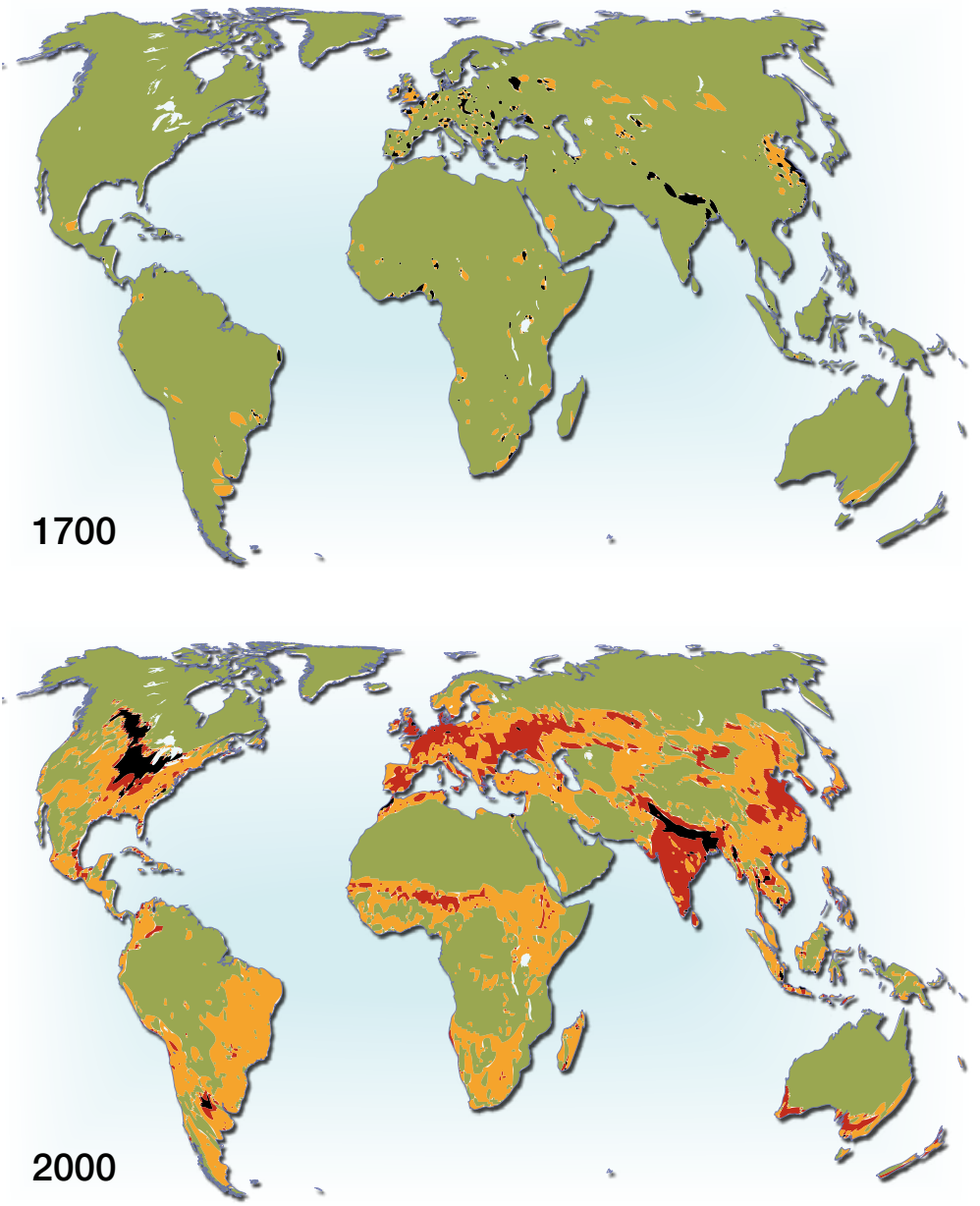

Biodiversity, as ratio of species abundance before human impacts

$\begin{array}{lcl}\text { High impacts } & 0-25 \\ \text { High-medium impacts } & 25-50 \\ \text { Medium-low impacts } & 50-75 \\ \text { Low impacts } & 75-100 \%\end{array}$

Mean species abundance (\%)

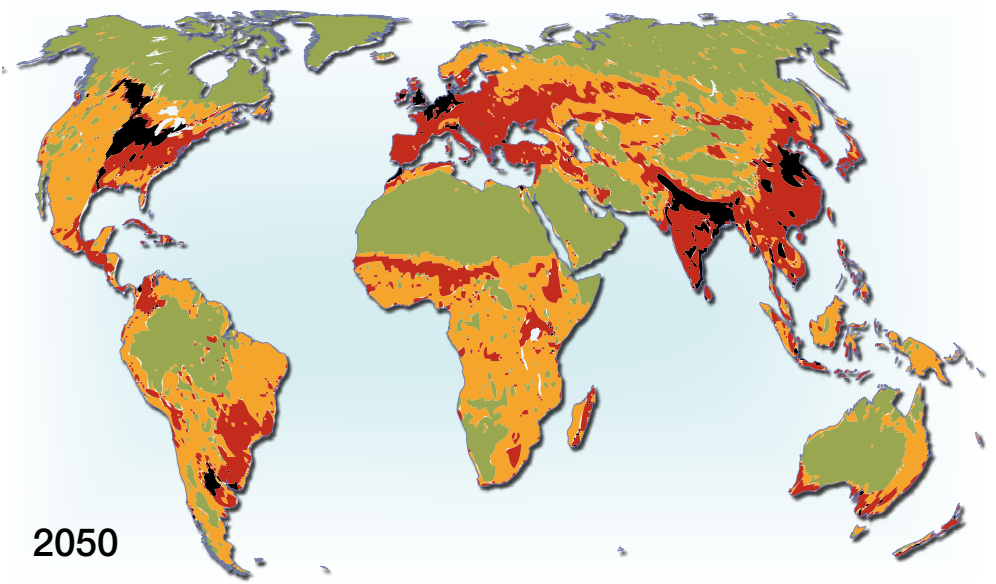




\section{ECOSYSTEM RESTORATION FOR BIODIVERSITY CONSERVATION}

The conservation of biodiversity is recognised as important due to the role biodiversity plays in underpinning many of the ecosystem services which humans depend upon form their well-being (MA 2005). Furthermore, it is well documented globally that habitat loss is a direct driver of species loss, and one mechanism to bring species diversity back to a site is through restoration of the ecosystem or habitat (SER 20I0). And while it has been documented that restoration does not necessary achieve the same value of biodiversity or ecosystem services found in intact ecosystems (Benayas et al 2009), there are many good examples of were informed ecological restoration programmes have been able to deliver biodiversity, including the recovery of threatened species and ecosystems (Lindenmayer et al. In press).

The services humankind receives from complex ecosystems include regulation of water supplies and water quality, maintenance of soil fertility, carbon sequestration, climate change mitigation and enhanced food security, to mention a few. Provision of these services is dependent upon the functioning of ecosystems, which is characterized by complex interactions between organisms and their biological and chemical environments. The environmental degradation that has occurred in many parts of the world has a negative impact on such functioning, and can reduce the provision of services on which human livelihoods depend.

Ecological restoration is increasingly being used to reverse the environmental degradation caused by human activities. One of the key objectives of such restoration is to improve the functioning of degraded ecosystems, to increase both biodiversity and the ecosystem services provided to humankind.
Although ecological restoration is now being undertaken throughout the world, evidence regarding the effectiveness of such activities has been lacking. However, a systematic metaanalysis of 89 restoration assessments was recently published in the journal Science, integrating the results obtained from restoration actions in a wide range of ecosystem types from throughout the world. Results indicated that ecosystem restoration was consistently effective in improving ecosystem services (Banayas et al., 2009).

From the 89 studies, 526 quantitative measures of variables relating to biodiversity and ecosystem services were extracted and incorporated into a database. The ecosystem services were classified according to the scheme developed by the Millennium Ecosystem Assessment (MA, 2005), which distinguishes four categories: I) supporting (e.g., nutrient cycling and primary production), (2) provisioning (e.g., timber, fish, food crops), 


\section{Correlations between response ratios for biodiversity and for provision of ecosystem services}

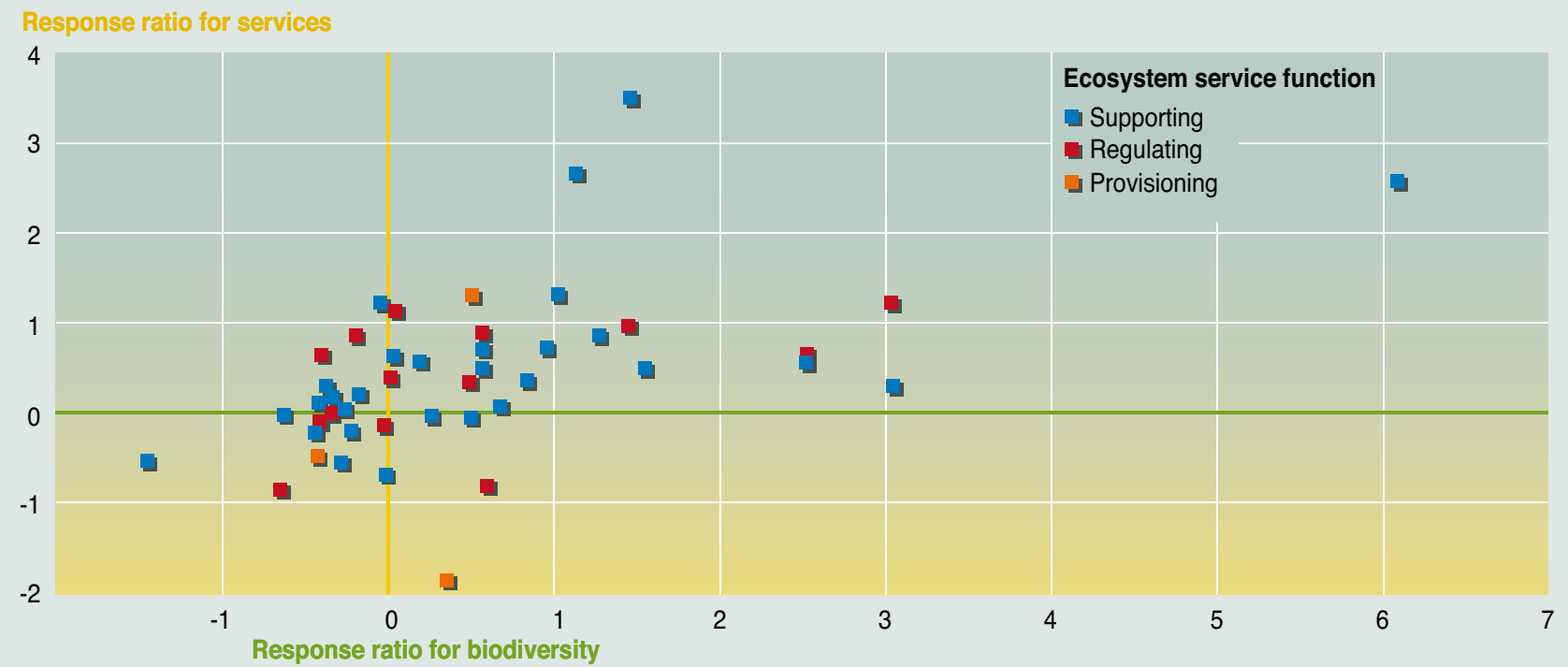

Source: Benayas, et al. Enhancement of Biodiversity and Ecosystem Services by Ecological Restoration: A Meta-Analysis, Science, 2009.

Figure 4: The relationship between biodiversity and degree of ecosystem service restored.

(3) regulating (e.g., of climate, water supply, and soil characteristics), and (4) cultural (e.g., aesthetic value). In the study only the first three services were assessed, because cultural services were not measured explicitly in any of the studies addressed. Measures of biodiversity were typically related to the abundance, species richness, diversity, growth, or biomass of organisms present.

The study revealed that ecological restoration increased provision of biodiversity and ecosystem services by 44 and $25 \%$, respectively across the 89 studies of different restoration projects. However, values of both remained lower in restored versus intact reference ecosystems, underlining the challenges and timescales required to fully restore a degraded ecosystem. Ecological restoration was particularly effective in tropical terrestrial areas, which hold the largest amounts of biodiversity and are usually subject to high levels of human pressure.
The meta-analysis revealed another crucial finding: increases in biodiversity and ecosystem service measures after restoration were positively correlated. This indicates that restoration actions focused on enhancing biodiversity should support increased provision of ecosystem services, particularly in tropical terrestrial biomes. Conversely, these results suggest that ecosystem restoration focused mainly on improving services should also have a primary aim at restoring biodiversity, as ecosystem services and biodiversity are intrinsically linked.

Ecological restoration can act as an engine of economy and a source of green employment, so the results of this research give policymakers an extra incentive to restore degraded ecosystems.

Figure 5: Ecosystem service response to restoration in different biomes. 


\section{Ecosystem services responses to restoration for different biomes}

Median response ratio for analysed surveys

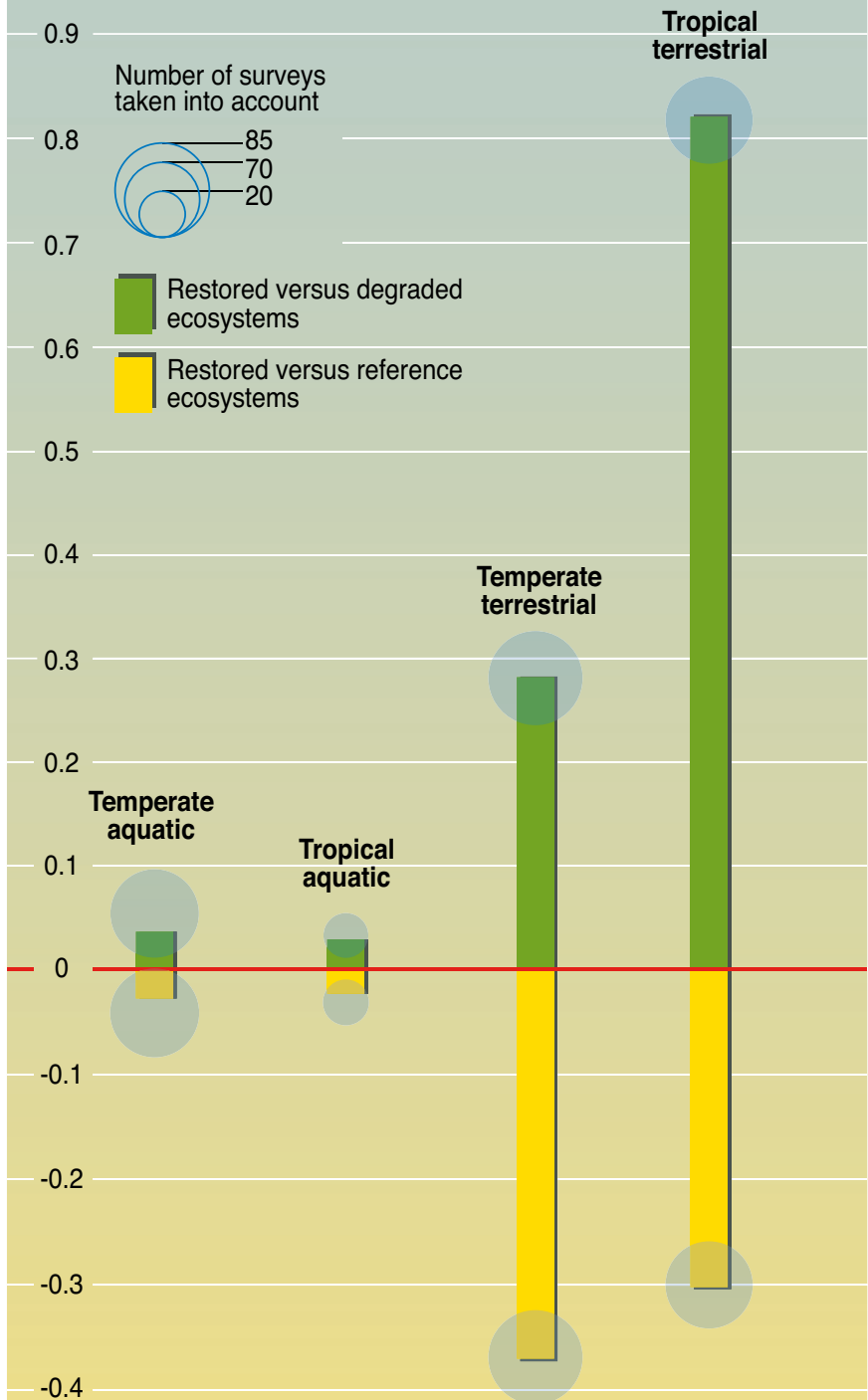

Source: Benayas, et al. Enhancement of Biodiversity and Ecosystem Services by Ecological Restoration: A Meta-Analysis, Science, 2009.

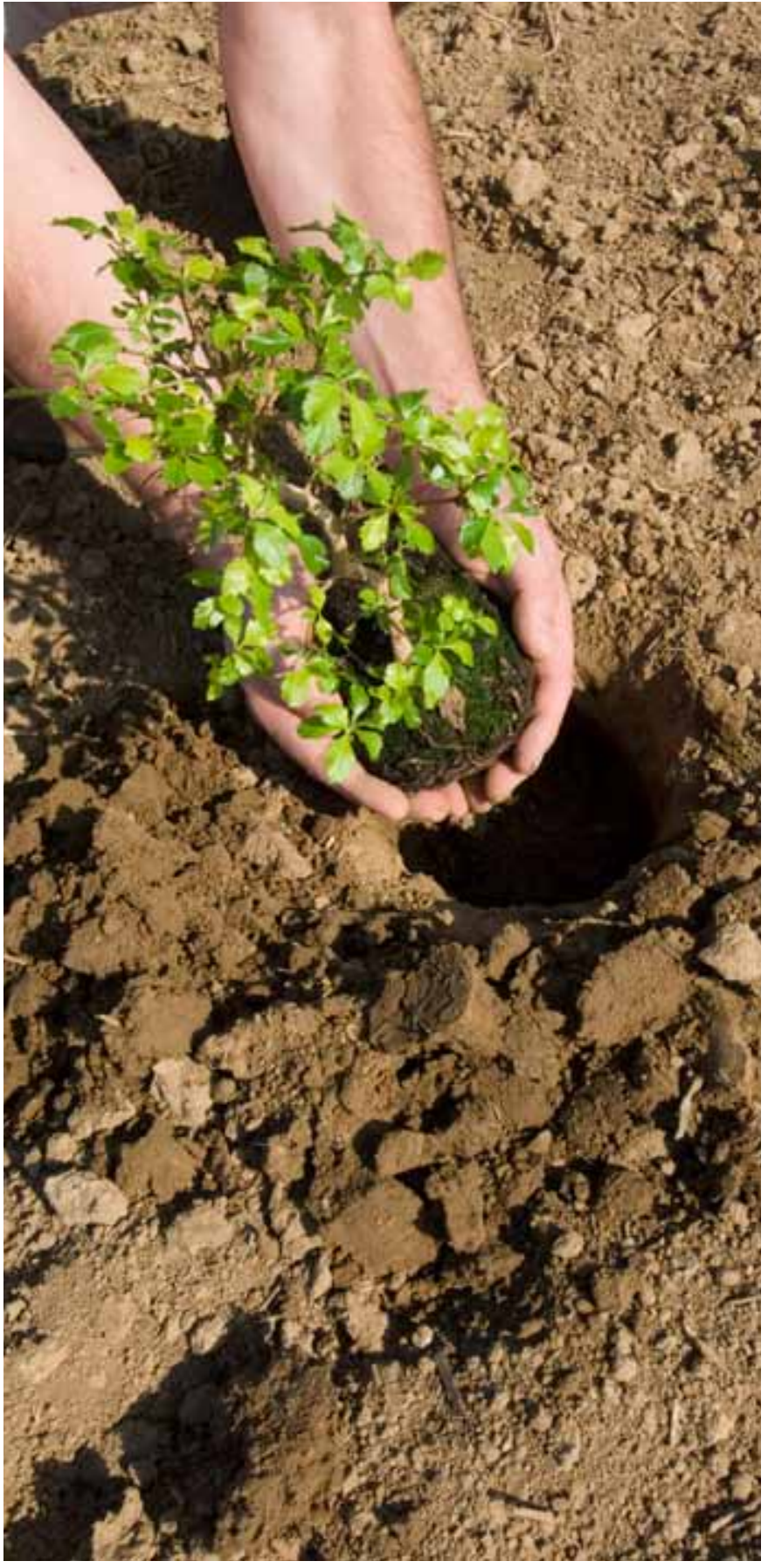




\section{A FOCUS ON FORESTS}

Extensive and ongoing deforestation during the past fifty years has lead to loss of biodiversity and decline in the goods and services for rural people (TEEB, 2008). Forests provide an array of benefits, from clean water, regulation of climate and biodiversity protection to sources of income, fuel and food (Kaimowitz, 2003; Chazdon, 2008). An estimated I.6 billion people in the world rely heavily on forest resources for their livelihoods (WRI, 2005; Chomitz, 2007). They range from multinational companies to rural farmers. In a time of widespread global poverty, increasing population and degraded ecosystems, these benefits are increasingly important. However, the ability of forests to deliver the economic, environmental and social benefits we all need to survive and prosper is serious under threat (Chomitz, 2007). Intensive exploitation coupled with the rapid

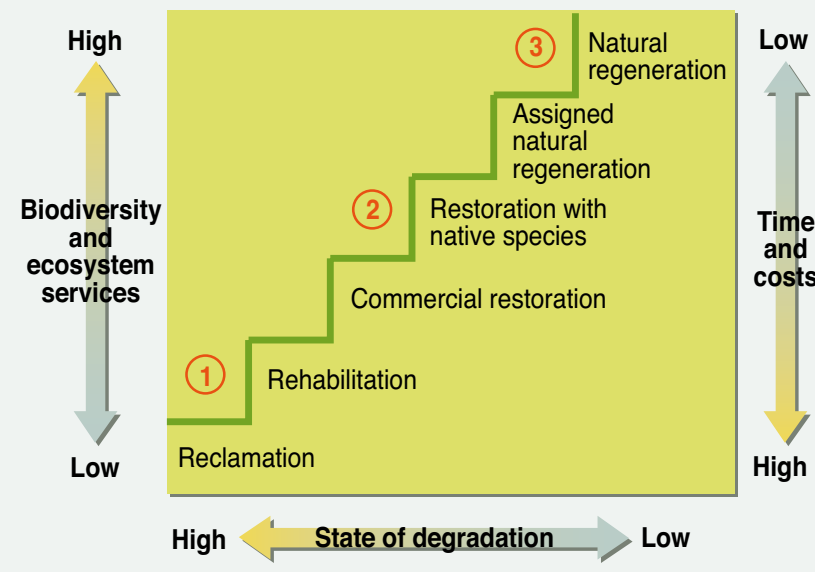

Depending on the state of degradation of an ecosystem, a range of management approaches can at least partially restore levels of

biodiversity and ecosystem services given adequate time (years) and financial investment (capital, infrastructure and labour). Outcomes of particular restoration approaches are:

\footnotetext{
1 restoration of soil fertility for supporting ecosystems;

2 production of some products such as timber; or

3 recovery of biodiversity and ecosystem services
}

Source: adapted from Chazdon et al., Beyond Deforestation: Restoring Forests and Ecosystem Services on Degraded Lands, Science 2008 growth of population, consumption patterns, development of agriculture, urban construction and other related disturbances as well as improper forest management, have resulted in large and expanding areas of degraded forest ecosystems (Wenhua, 2004, TEEB, 2008). This trend can be reversed through restoration and rehabilitation forests of degraded forest ecosystems.

In both developed and developing countries, assisted restoration and unassisted forest regeneration are gaining momentum (Sayer et al, 2004; Chazdon, 2008). Forests are being restored for many purposes in many ways and at increasing rates by local communities, non-governmental organisations and private agencies, as well as through state and national programmes. The projects and programmes have differed in scale, objectives,

\section{Some of the benefits of forest restoration}

- Increased and higher quality habitats for animals and plants;

- A secure and high-quality supply of water;

- Prevention and reduction of land degradation;

- A secure source of biomass and biofuel energy;

- Environmentally sound and socially acceptable carbon sequestration;

- Adequate and sustainable income and employment opportunities for rural communities;

- Sustainable source of timber for forest industries and local communities;

- Sound return on investment for forestry investors;

- Increased resilience and resistance to climate change;

- Additional sources of non-timber forest products such as medicinal plants and marketable goods;

- Recreation and tourism opportunities;

- Increased property values near restored areas;

- Enhanced economic and environmental security and mitigation of risk form global economic and environmental change.

Source: Global Partnership on Forest Landscape Restoration (GPFLR), http://www.ideastransformlandscapes.org

Figure 6: The restoration staircase. 
Economic worldwide benefits coming from biodiversity

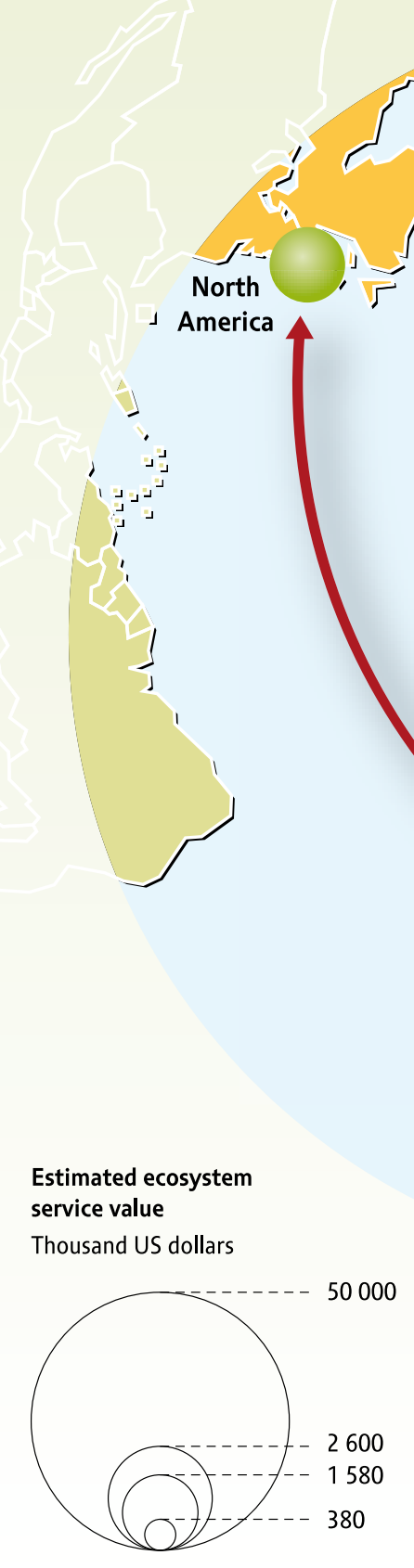

Figure 7: Worldwide benefits from biodiversity in Madagascar.
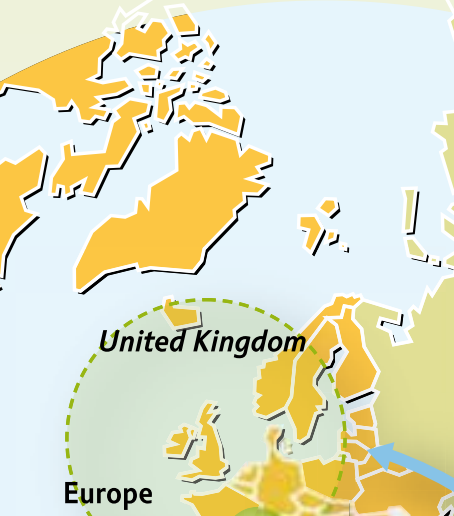

Europe

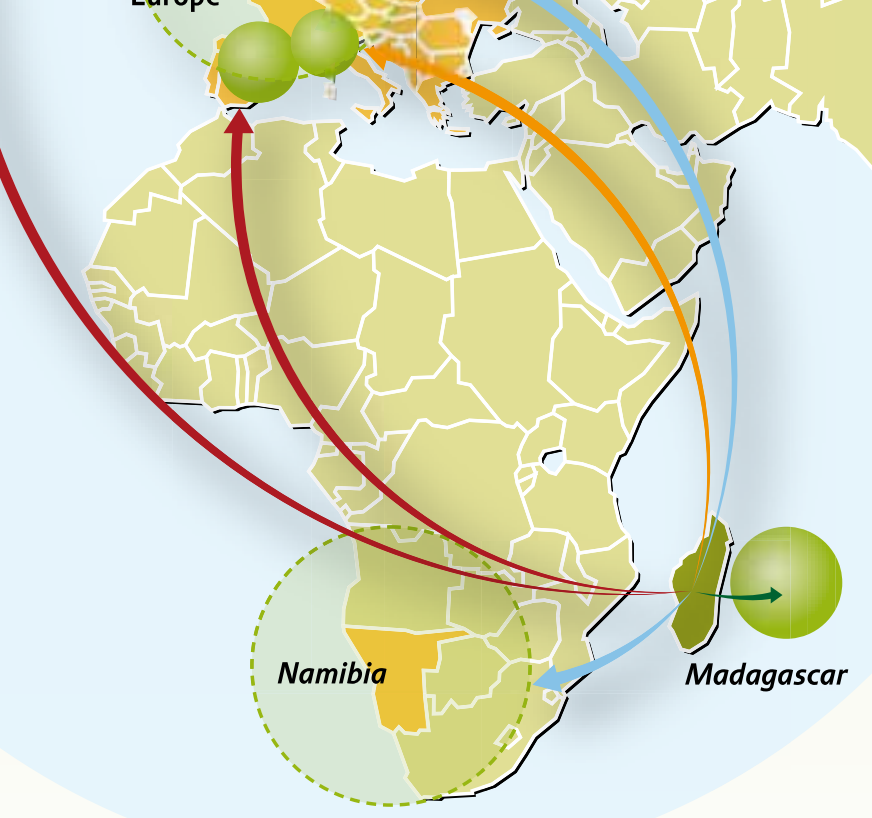

000

Source: TEEB, 2008.
Service provided

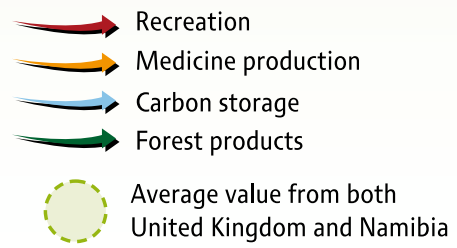


implementation strategies, duration, and in how much they considered socio-economic and institutional aspects, which are essential for successful restoration (CIFOR, 2002). Forest restoration can restore many ecosystem functions and recover many components of the original biodiversity. Approaches to restoring functionality in forest ecosystems depend strongly on the initial state of forest or land degradation and the desired outcome, time frame, and financial constraints (Fig. 6).

In many deforested, degraded and fragmented forest habitats investments in restoration and rehabilitation forests can yield high biodiversity conservation and livelihood benefits (Sayer et al, 2003, Chazdon, 2008; TEEB, 2009; TEEB, 2009).

\section{WHAT ARE THE BENEFITS TO BIODIVERSITY/CONSERVATION FROM FOREST RESTORATION?}

Restoration in densely settled tropical areas can have more impact on biodiversity than further extension of "paper parks" in remote, pristine forests and can also deliver important forest goods and services to a wider range of stakeholders (Sayer et al, 2003). Retention of even small fragments of natural vegetation is justified by their great potential value in providing the building blocks for future restoration programmes. Restored forests can improve ecosystem services and enhance biodiversity conservation (Chazdon, 2008). Along the Mata Atlantica in Brazil a non-profit organization named Instituto Terra undertakes active restoration of degraded stands of Atlantic Forest by establishing tree nurseries to replant denuded areas (Instituto Terra 2007). Benefits include biodiversity enhancement, water regulation, carbon storage and sequestration as well as preventing soil erosion. In Vietnam, forest restoration thorough planting indigenous tree species and fostering natural regeneration has lead to increased water supply as well as increased and higher quality habitats for animals and plants as shown in case study 2 (Poffenberger, 2006). Restoring eucalyptus woodlands and dry forests on land used for intensive cattle farming in southeast Australia was found to yield numerous benefits including reversing the loss of biodiversity, halting land degradation due to dryland salinisation and thereby increasing land productivity (Dorrough and Moxham, 2005).

\section{CASE STUDY \#2}

\section{Restoration of limestone forests in Phuc Sen in Northwestern Vietnam}

In Son La District in Northwestern Vietnam, Tai and Hmong communities have managed upland forests for generations. Forests are classified according to function including old growth protected areas ( $\mathrm{Pa}$ Dong), younger secondary forests that are part of long rotation swiddens ( $\mathrm{Pa} \mathrm{Kai}$ ), early regenerating forests ( $\mathrm{Pa} \mathrm{Loa}$ ) and bamboo forests $(\mathrm{Pa})$. The lands are held under communal tenure and allow for a well-managed landscape that supports considerable biodiversity. In Cao Bang Province, to the North the Nung an ethnic community found that their limestone forests had degraded because of the growing fuelwood and timber extraction pressures from State Forest Enterprises and local villages. After biodiversity and hydrology began to deteriorate in the 1960s andig7os, the communities in Phuc Sen organised to divide forest protection among the 12 villages. A combination of planting with indigenous pioneering tree species like mac, rac and more valuable timber species, combined with natural regeneration, has led to the reforestation of many of the limestone hillocks in the area. The restoration of the limestone forests has facilitated the reestablishment of spring flows that provide water for the lowland rice fields. It has also allowed for the return of many indigenous mammal species, including five endemic and 26 rare species. The process is currently being replicated through a Community Forest Network operating at the district and provincial level (Dzung et al., 2004). In many parts of upland Southeast Asia, communities are organising to protect threatened upland forests. Part of these initiatives deal with outside pressures from private sector timber enterprises as well as from the expansion and commercialisation of agriculture. The emergence of community forestry networks is apparent in upland areas of Indonesia, Vietnam, Thailand and Cambodia.

Source: Poffenberger, 2006 pg. 11 


\section{WHAT ARE THE HUMAN LIVELIHOODS/ HUMAN WELL-BEING IMPACTS OF FOREST RESTORATION?}

Forest restoration can also play crucial role in livelihood improvements and human well-being. These benefits include enhancing adaptation capacity, contributing to food security and improving the livelihoods of people depended on forest ecosystems, community empowerment among other things (CIFOR, 2002) .For example, in the Shinyanga region of Tanzania, the HASHI program helped local people from 833 villages to restore 350,000 ha of acacia and miombo woodland through traditional pastoralist practices in only I 8 years. The benefits to people livelihoods have been significant. Ecological restoration can also improve productivity, livelihoods and economic opportunities through reducing soil degradation, desertification and water loss. Experience from these and other forest restoration projects, show that in most cases it is of paramount importance that local communities are placed in the centre of attention (i.e. considered as the key actors and involved in decision-making processes). Crucial issues to consider when implementing forest restoration are land tenure, incentives, access to resources and to management rights, natural versus exotic species, and appropriate monitoring and evaluation instruments (CIFOR, 2002; WRI, 2005; Chazdon, 2008). Additionally, enabling conditions are always strongly policy-related. Sometimes they may have to be simple set-ups which strongly facilitate decision-making and implementation processes. Economic push and pull mechanisms are needed to launch a policy dialogue, involving both government representatives and the poorest

\section{CHALLENGES}

There are many challenges to successful forest restoration. For example, a high rate of failure will result in plantations if selected tree species are not suited to site conditions or if the appropriate hydrological patterns are not also restored, too few species are planted. Invasive species may establish more easily in monoculture tree plantations and have greater susceptibility to species-specific pathogens (Chazdon 2008).

The future implications of large-scale forest restoration on the structure and composition of forests, landscapes and fauna is

\section{CASE STUDY \#3}

\section{Regenerating Woodlands: Tanzania's HASHI Project}

In the Shinyanga region of Tanzania, large areas of dense acacia and miombo woodland were cleared by 1985 , transforming the landscape into semi-desert. The HASHI project, whose success was recognized by the UN Development Programme with an Equator Initiative prize in 2002, helped local people from 833 villages to restore 350,000 ha of acacia and miombo woodland through traditional pastoralist practices in only 18 years. Its striking success stems from the rich ecological knowledge and strong traditional institutions of the agro-pastoralist Sukuma people who live in the region. By 2004, 18 years into the project, at least 350,000 hectares of ngitili (the Sukuma term for enclosures) had been restored or created in 833 villages, encompassing a population of 2.8 million (Barrow and Mlenge 2004:1; Barrow 2005b). Benefits of the restoration include higher household incomes, better diets, and greater livelihood security for families in the region. Nature has benefited too, with a big increase in tree, shrub, grass, and herb varieties, as well as bird and mammal species.
The Shinyanga case illustrates the importance of working with local people. In the past, the state imposed its own solutions, which often failed. The Shinyanga project has involved local people in the entire process of landscape restoration. It has built on local institutions rather than creating new ones. Villages have been encouraged to pass their own by-laws to protect communal ngitilis (enclosures of acacia-miombo woodlands), and traditional village guards monitor activities in the ngitilis. Local involvement has been critical to the success of the project. Forest restoration has also strongly benefited from the Tanzanian government's push towards decentralisation, which involved the allocation of clear land rights to local communities. Greater security of land tenure has engendered a sense of ownership and responsibility among the Sukuma agropastoralists, whose large herds of cattle now co-exist in a healthier environment.

Source: Monela et al, 2004 


\section{Socio-economic benefits from grassland restoration projects, South Africa}

In the Drakensberg mountains, local communities depend heavily on various ecosystem services for their livelihoods. By restoring degraded grasslands and riparian zones and changing the regimes for fire management and grazing, early results suggest that it may be possible to increase base water flows during low-flow periods (i.e. winter months when communities are the most vulnerable to not having access to any other source of water) by an additional 3.9 million $\mathrm{m}^{3}$. Restoration and improved land use management should also reduce sediment load by 4.9 million $\mathrm{m}^{3} /$ year. While the sale value of the water is approximately $€ 250,000$ per year, the economic value added of the ad- ditional water is equal to $€ 2.5$ million per year. The sediment reduction saves $€ 1.5$ million per year in costs, while the value of the additional carbon sequestration is $€ 2$ million per year. These benefits are a result of an investment in restoration that is estimated to cost $€ 3.6$ million over seven years and which will have annual management costs of $€ 800,000$ per year. The necessary ongoing catchment management will create 310 permanent jobs, while about 2.5 million person-days of work will be created during the restoration phase.

Source: Maloti Drakensberg Transfrontier Project (MTDP), 2007.

\section{CASE STUDY \#5}

\section{Limestone Quarry Restoration in Perth, Australia}

Application of smoke to the topsoil seedbank within post-mined restoration sites in Australia results in a trebling of seedling emergence success. Whilst 'smoke tents' were employed during the research phase in the 1990's (left), scientists have now discovered, isolated and have the capacity to synthesize the chemical in smoke responsible for seed germination. This, together with

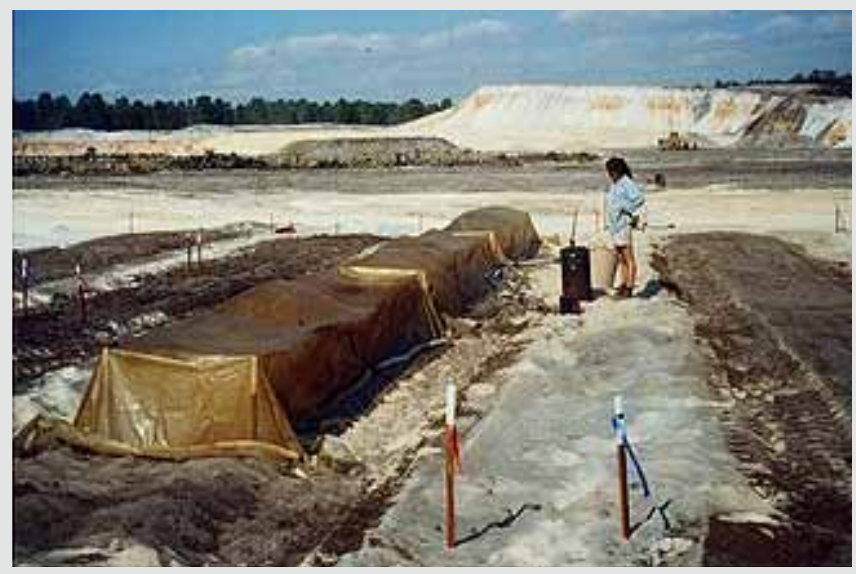

other germination tools and techniques such as seed pelleting and correct topsoil handling, paves the way for restoration practitioners to achieve high species return on ancient landscapes within the biodiversity hotspot of southwestern Australia (right).

Photo credit: Deanna Rokich. Source: Wetland Care, Australia

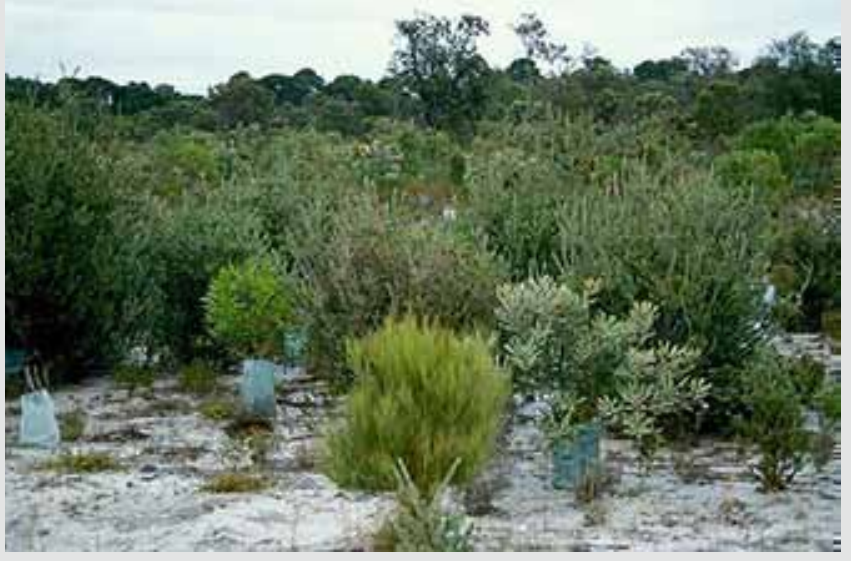




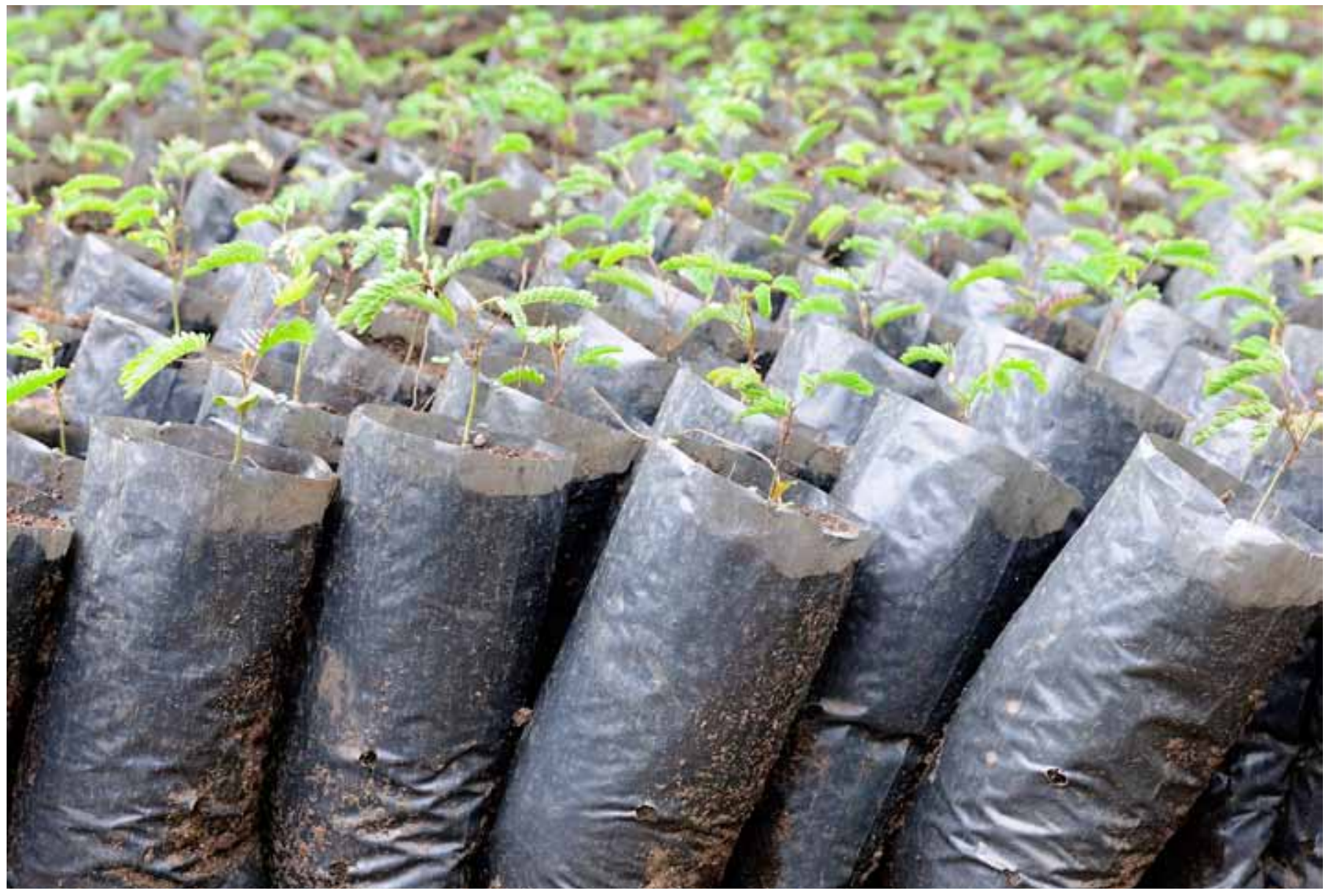

not well understood. Also inadequately studied is the influence of various restoration approaches on restoring ecosystem services, even though the links between biodiversity, functional traits, and ecosystem services are well acknowledged (Chazdon 2008).

Even with an understanding of the dynamics of the forest ecosystem, restoration will not succeed without consideration and awareness of interacting socioeconomic and political systems (ITTO 2002).

\section{OPPORTUNITIES}

The opportunities for forest restoration is considerable, since the extent of forest degradation in the tropics has been esti- mated as 350-850 million ha, depending on the level of degradation (ITTO 2002). Indeed, The Global Partnership on Forest Landscape Restoration (GPFLR) estimates that over I billion hectares of previously forested lands are currently suitable for broad scale or mosaic restoration, approximately $6 \%$ of the earth's total land area (GPFLR 2009).

Incentives for increasing carbon stocks in vegetation has lead to increased motivation for a wide range of forest restoration activities, but the choice of species in reforestation projects have not always complemented long-term carbon sequestration. It is important to recognize that forest regeneration and restoration are long-term processes, requiring Ioo years or more (Chazdon 2008). 


\section{Restoring fish passage and tidal flows in the Clarence river estuary, Australia.}

After decades of being alienated from marine and estuarine waters, Shallow Channel in the lower Clarence river estuary, on the east coast of Australia, has been reunited with tidal flows. Important seagrass beds and fish nursery areas in Shallow Channel have been isolated from the main tidal habitats in Clarence river estuary for over 80 years. The Clarence river estuary is one of the largest deltas on Australia's east coast and is noted for its rich aquatic and migratory bird life. It is also home to numerous threatened species including the black necked stork, mangrove honeyeater, osprey and the black flying fox. It contains endangered ecological communities such as saltmarsh and subtropical coastal floodplain forest and is listed on the Directory of Important Wetlands in Australia.

The Shallow Channel causeway, in northern New South Wales, was first constructed in the 1920 from logs. In the 1960 s the causeway was rebuilt as a modern road, but with no provision to allow water to flow under the road. As a result of the blockage of tidal flows sediments and nutrients began to build-up. This caused algal blooms and raised temperatures in the still, shallow water, resulting in algal bleaching and death of the seagrass beds. The causeway acted as a total barrier to fish passage, isolating the remaining (dwindling) fish populations from the main estuary.

Re-establishing tidal flow-through and fish passage at Shallow Channel causeway had long been identified as a major factor to
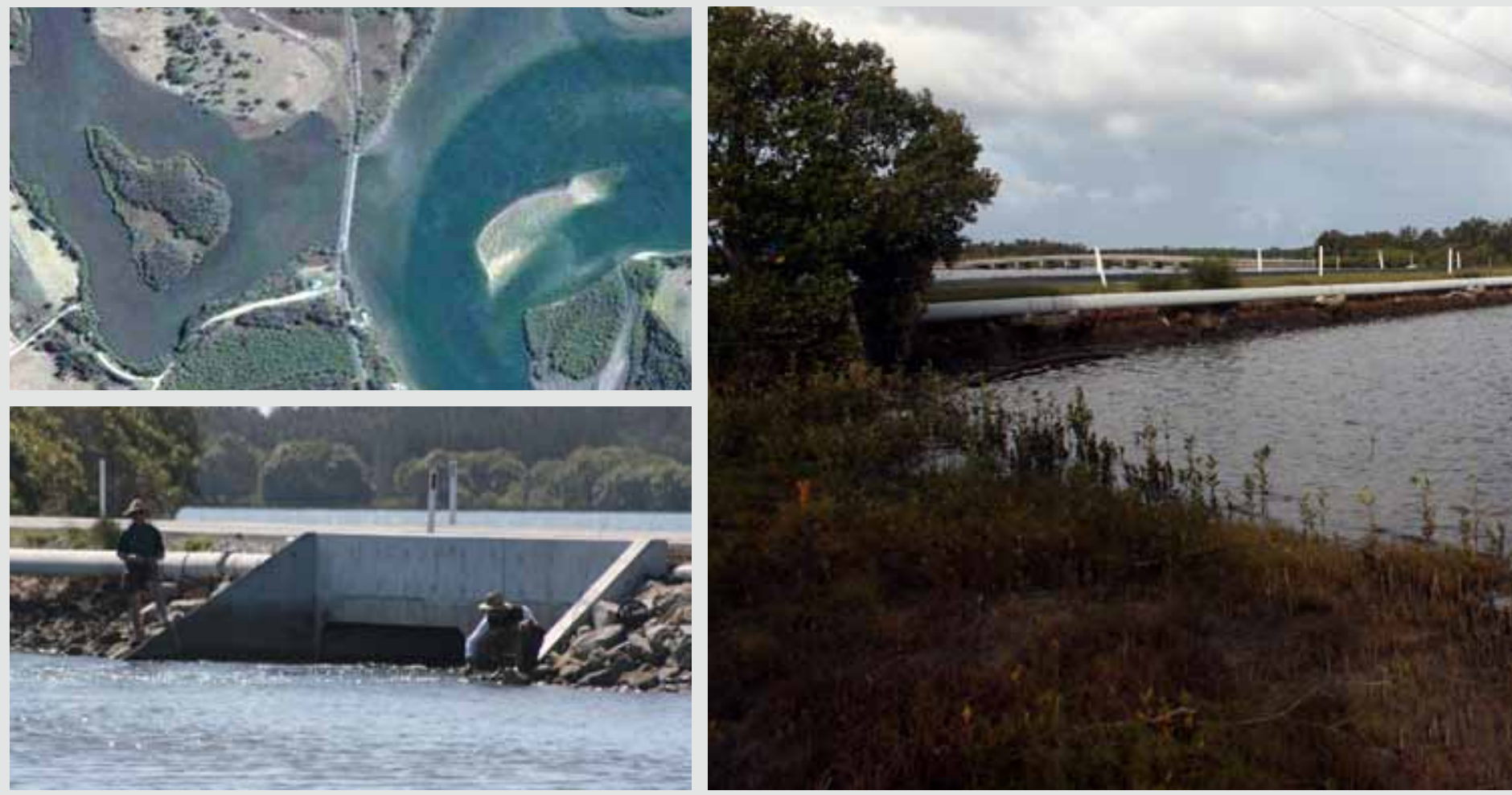
improve ecological processes in the lower Clarence estuary. In 2006, after years of consultation, geotechnical studies and extensive stakeholder engagement, WetlandCare Australia initiated the installation of a large doublecell box culvert. This design allowed the greatest volume of tidal exchange and the best access for fish passage.

The completed culvert has dramatically improved connectivity between Shallow Channel and Oyster Channel for tidal flows and fish passage. The once permanently-submerged sandbars and mudflats in Shallow Channel are now exposed at low tide and wading birds have returned. Over time, sediment will be mobilised and the channel structure reinstated. Nutrient and dissolved oxygen levels are returning to normal, and the site no longer suffers de-

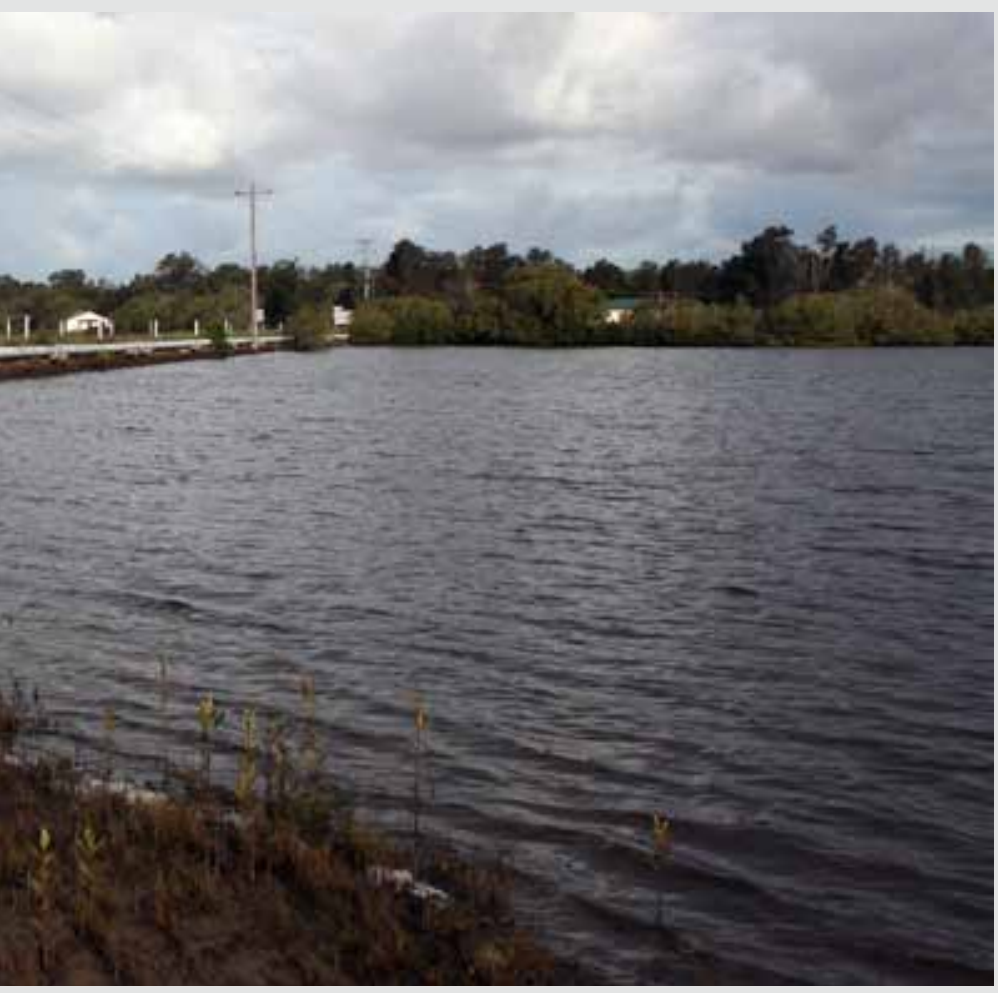

bilitating extremes of temperature. This has relieved the previous stresses on seagrass beds and other important aquatic habitats, and vastly improved the overall ecological health of Shallow Channel.

Fish passage has greatly improved, with recreational fishers now regularly joining the active pelicans in Shallow Channel. Numerous fish species including whiting, flathead, yellowfinned bream, eel and mullet have benefited from the improved fish passage and habitat at Shallow Channel. The value of the area as a food resource for resident and migratory shore birds such as pelicans, oystercatchers, terns, egrets, sandpipers and spoonbills has also increased.

(far left, top) Shallow Channel causeway, showing Shallow Channel on the left and Oyster Channel on the right (Photo - Google Earth). Tidal flow has been blocked since the 1920s, causing significant damage to seagrass beds, mudflats and fish habitat. A large decline in shorebirds, fish species and overall ecosystem productivity has since occurred, a process which is being reversed since the installation of a large double cell box culvert.

(far left, bottom) Recreational fishers enjoying the new culvert in the Shallow Channel Causeway. Prior to the culvert being built the area was not used by recreational fishers at all, a reflection of the extremely low fish stocks present at that time. Photo credit: Alan Cibilic, WetlandCare Australia

(left) Shallow Channel mudflats have been restored by the return of tidal flows through the culvert. Photo credit: Alan Cibilic, WetlandCare Australia 


\section{Restoring wetlands following agricultural expansion: Lake Wales Forest Restoration, Polk County, Florida USA}

Much of the world's existing agricultural lands are converted native wetland and upland habitats that for a variety of ecological and economic reasons should be considered for ecosystem restoration. The 400 acre Lake Wales Forest Mitigation and Net Ecosystem Benefit Site (LWF) successfully restored a complex mosaic of hardwood swamp forests, freshwater marshes and xeric scrub habitat on the Lake Wales Ridge to compensate for impacts related to the installation of a gas pipeline by Gulfstream Natural Gas Systems in near-by sections of the state.

The Ridge is one of the most distinctive natural regions in the US forming a north-south oriented area of sandy uplands at the center of the Florida peninsula. It is a series of relict dunes, reflecting its origins 2 million years ago as a shoreline feature during pre-Pleistocene sea level rises, and at times it was an archipelago. This isolation contributed to the evolution of the numerous, rare endemic plant species and animals of the Ridge, many of which are now on state and Federal endangered species lists. Native xeric uplands are dominated by pines, shrubby oaks, and hickory with bare open sandy areas. This property was selected for restoration due to its location on the Ridge and the rare xeric scrub habitat intermixed with wetlands that once existed on the site.

The site was systematically drained, cleared and put into improved pasture in the 1950's and 60's, eliminating native habitats and reducing wildlife utilization as a result. In 2001, Kevin L. Erwin Consulting Ecologist, Inc. imple- mented multiple restoration and management methodologies to accomplish the parameters required by the complex diversity of target habitats once found on the property. The historic ground and surface water levels were restored by strategically placing a series of water control structures in the drainage canal system raising levels 2 to 3 meters. Once appropriate hydrology had been achieved, native habitats were restored through plantings and direct seeding of native vegetation. In total, approximately 143 acres of wetland forests, 34 acres of freshwater marsh, and more than 220 acres of uplands (including approximately 170 acres of rare xeric scrub habitat) have been restored on this site which now includes 20 species of listed plants. Ecologists have documented 97 (8 listed), 18(3 listed), 33(4 listed) and 18, bird, mammal, reptile and amphibian species respectively, all utilizing the restored habitats including 8 listed bird species, 3 listed mammal species, 4 listed reptile species, and 20 listed plant species. In addition to funding the restoration Gulfstream will establish a long term management fund and then transfer the restored property to conservation entity for long term protection.

Lake Wales Forest demonstrates that agricultural lands can be successfully restored to native ecosystems providing biodiversity conservation for rare or threatened habitats and species while providing appropriate compensation for unavoidable ecological impacts to similar areas.

Source: Kevin L. Erwin Consulting Lnc.

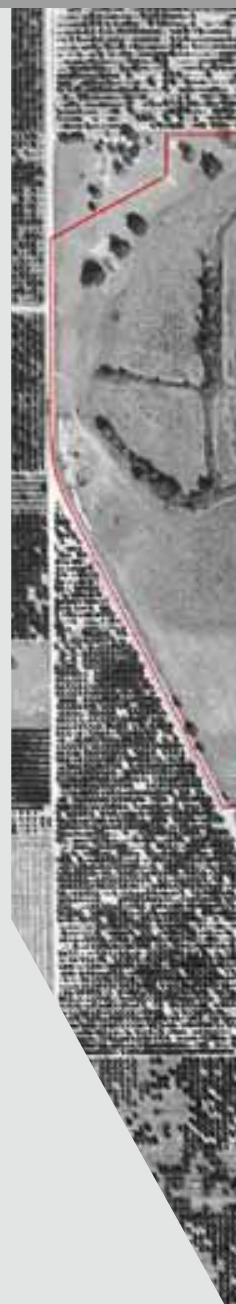




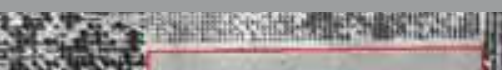

\section{andising}

.
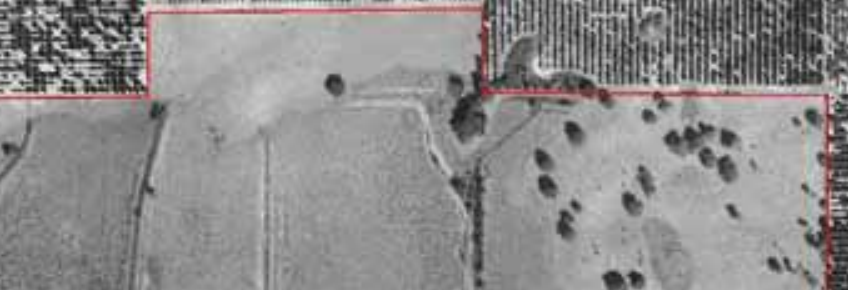

3.

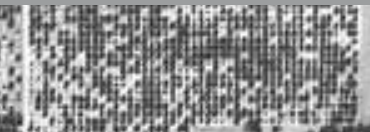

-

s.

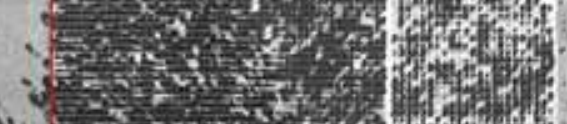

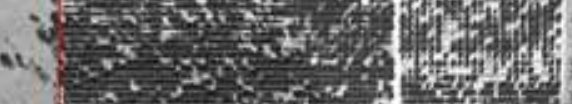

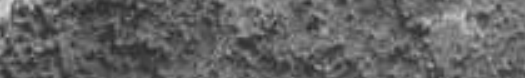
1)

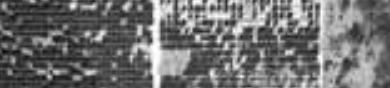

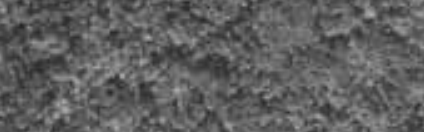

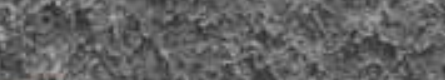

\section{Mone 5 .}

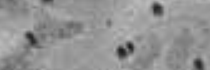

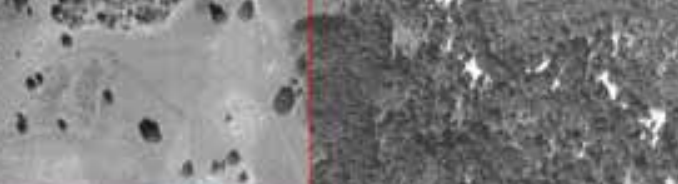

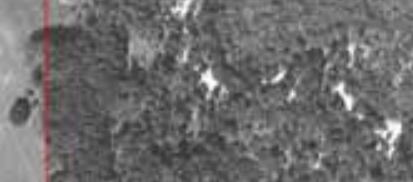




\section{Wetland restoration: Little Pine Island, Lee County, Florida, USA}

By the early 1990's, forty years of drainage canal impacts resulting from extensive mosquito ditching of this 4670 acre island, had resulted in the complete loss of freshwater habitats and extensive infestations of exotic plant species. Recognizing the ecological significance of this island which is now strategically located within the 40,000 acre Charlotte Harbor State Park, the State of Florida acquired the island in 1974 as its development was being planned, however the state had no plans to attempt any restoration activities due to the anticipated cost. In the early 1990's the new concept of mitigation banking appealed to both the State of Florida and a private developer, Mariner Properties Development, Inc. In 1997 restoration activities began, undertaken as a public private partnership that was formed between Mariner and the State as the Little Pine Island Wetland Mitigation Bank. One of the first of its kind in the US the bank has privately financed over 12 million USD in habitat restoration and its perpetual maintenance, ultimately from the sale of bank credits. Without this innovative financial arrangement it would not have been possible to undertake the carefully planned and phased restoration designed and monitored by Kevin L. Erwin Consulting Ecologist, Inc. Approximately 60 tons of biomass per acre was removed over nearly 2000 acres, consisting mostly of melaleuca (Melaleuca quinquenervia), Australian pine (Casuarina equisetifolia), and Brazilian pepper (Schinus terebinthifolius). These exotic trees dominated the island after drainage impacts occurred often forming a dense canopy and completely displacing the native plants and wildlife. As the exotic vegetation was removed in each phase, a deliberate process of backfilling the drainage canals commenced to restore the interior freshwater system and the natural tidal flows along shore. Recovery of the restored fresh and saltwater marshes, mangroves and slash pine wetland habitats has been remarkable. Following exotic removal and the restoration of natural hydropatterns, seeds of native wetland vegetation that for decades had been dormant in the soil have sprouted to produce well-balanced native ecosystems replete with wildlife $(11,109,17,7,13$ and 95 species of mammals, birds, reptiles, amphibians, fish and aquatic macro-invertebrates, respectively.

Little Pine Island Mitigation Bank is an excellent example of a highly successful, cost effective, risk free wetland restoration project consisting of regionally significant ecosystem restoration that will be perpetually maintained at absolutely no cost to the public. (Biodiversity Conservation, Financial Benefits of Innovative Ecosystem Restoration)

Source: Kevin L. Erwin Consulting Lnc.
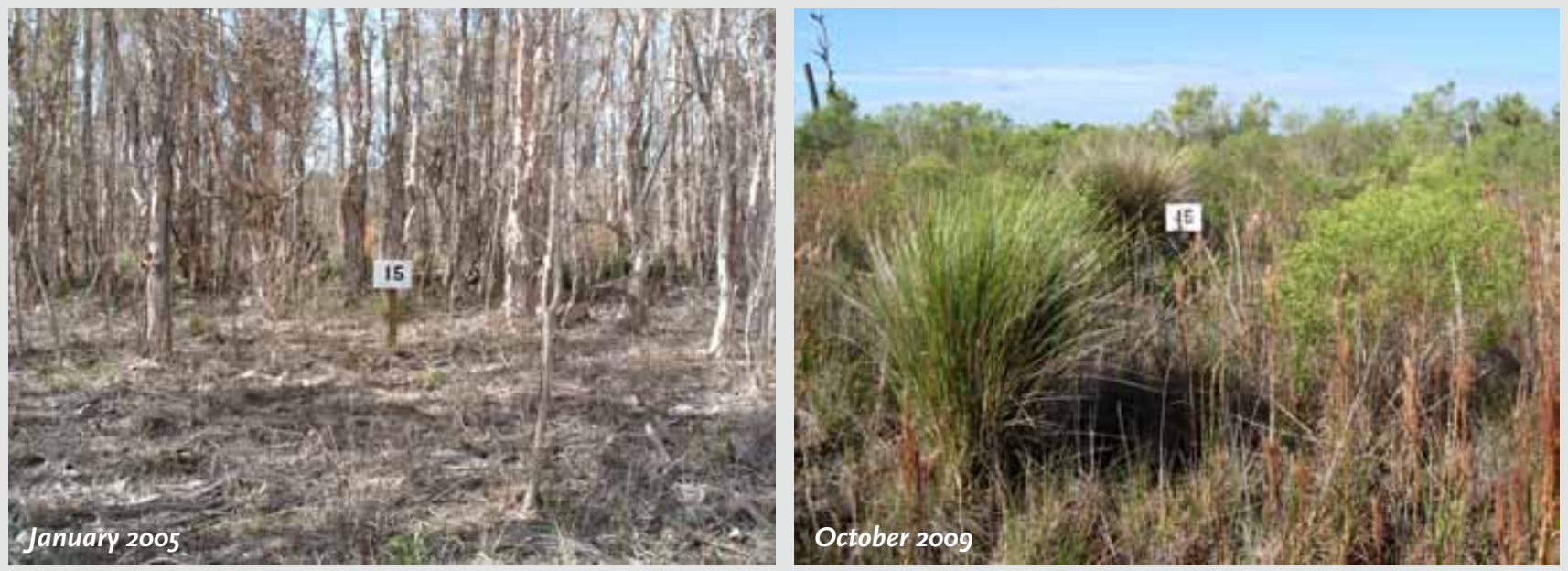


\section{Marks from vehicles in Arctic tundra}

In Arctic tundra, vehicles from seismic exploration, military training, mining or recreational 4wd ATVs may leave heavy marks in tundra and permafrost, lasting for decades or even centuries. Many restoration programmes focus on transplanting local plants to accelerate natural processes.

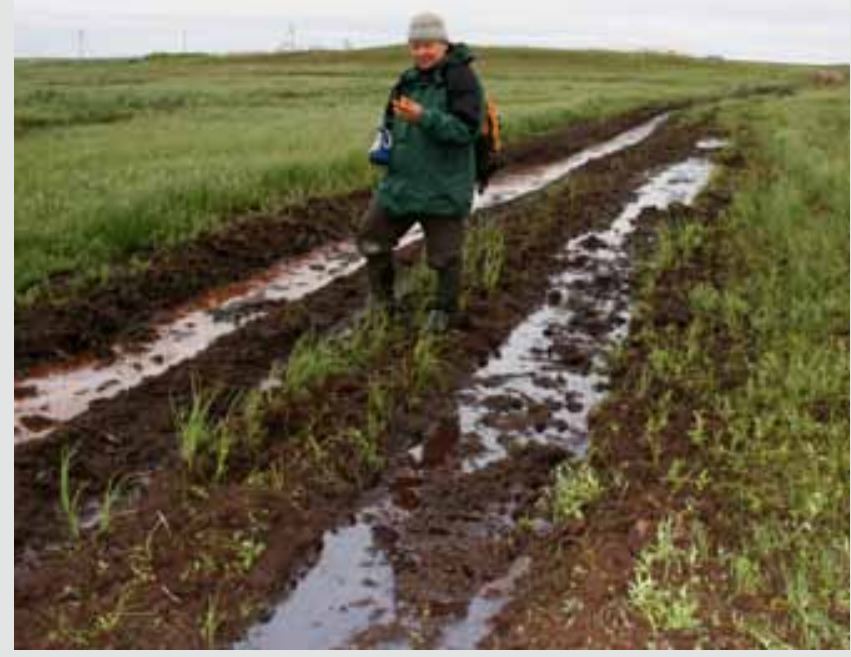

Fresh off-road vehicle tracks through sedge-moss tundra in the Nenets Autonomous Okrug, Arctic Russia. Such ruts form easily, yet tend to regenerate naturally relatively quickly in the absence of any slope or fluvial erosion. Vehicle tracks remain common in the Russian Arctic despite an official ban on their use in summer, when the ground surface is thawed, since the 1980s. Roads have the effect of reducing such traffic, yet lead to other, indirect impacts that may persist for decades, such as blowing sand, dust and changes in hydrology and chemistry in the vicinity of the road (see Forbes et al. 2001).

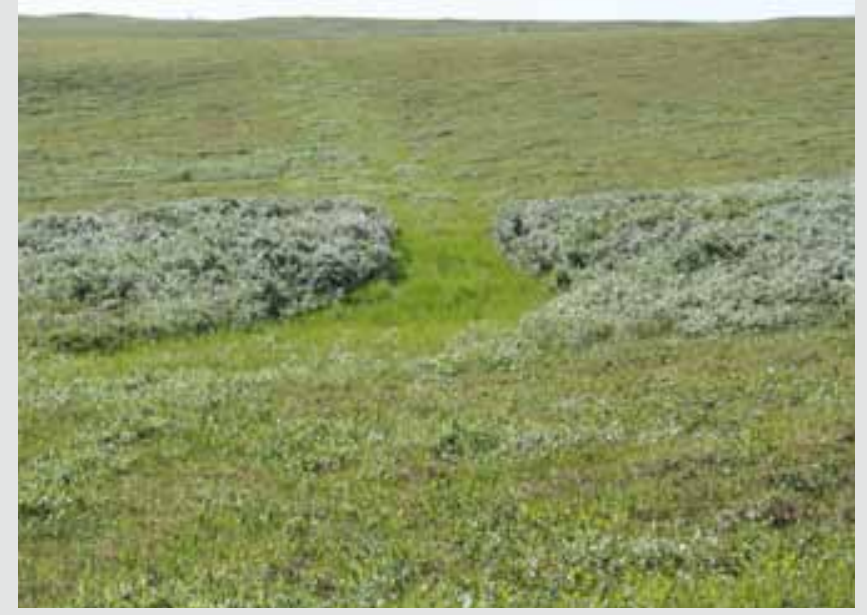

Graminoid-dominated strip characteristic of off-road vehicle tracks that have regenerated naturally. Disused for $\approx 20 \mathrm{yr}$ at the time of the photo, these are visible as linear features in very high resolution satellite imagery (see Forbes et al. 2009). Shrubs are completely displaced by such activity as the initial mechanical disturbance removes woody biomass and this is replaced by fastgrowing, clonal graminoids (grasses, sedges) that can then occupy the patch indefinitely. On drier ground, regeneration of a complete plant cover may take decades, or not occur where nutrients and moisture are inadequate. 


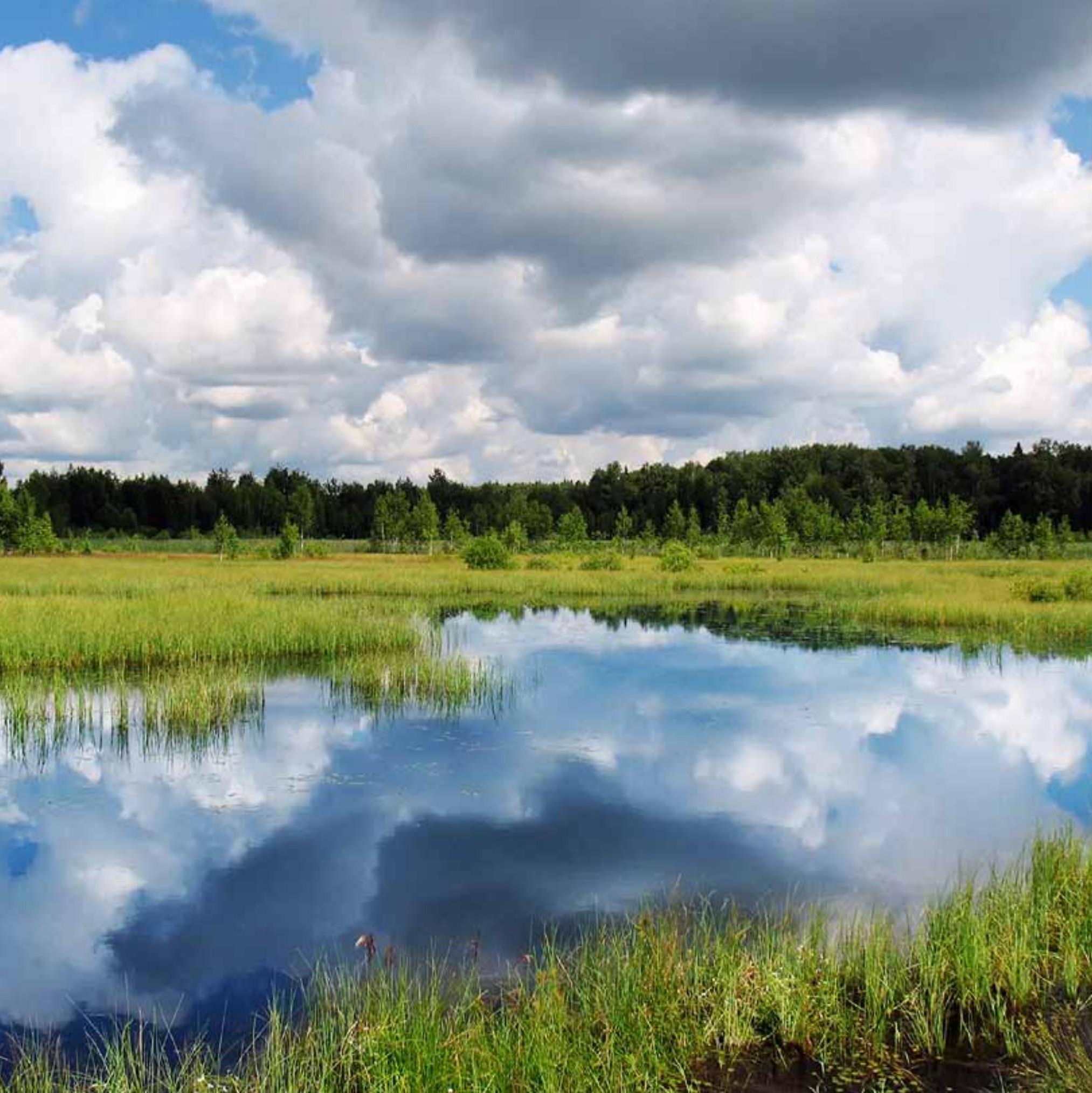




\section{ECOSYSTEM RESTORATION FOR WATER SUPPLY}

Forests play a key role in global water supply. At present $75 \%$ of globally usable freshwater supplies come from forested catchments (Fischlin et al. 2007), therefore water is critically linked to forests in much of the developing world. Forests are also crucial for flow regulation and in hindering flash-floods from water originating in mountains or in extreme rainfall events (UNEP, 2004; 2010, in press). This is crucial in terms of providing predictable water supply to crop areas, such as through retention of water in wetlands and forests buffering both droughts and floods (Bruijnzeel 2004; UNEP, 2005; ICIMOD, 2009). Forests also have a key function in climate regulation through influencing weather and rainfall, as well as in capturing rain- and mist water, such as in cloud forests (UNEP-WCMC, 2004) and in filtering water.

Mountain regions all over the planet are crucial water towers: Indeed, the Hindu Kush Himalayas supply water for over 55\% of Asia's cereal production or near $25 \%$ of the Worlds cereal production (UNEP, 2009; UNEP 20I0). Increased irrigation schemes were a key component of the former Green revolution in Asia, and 70-90\% of the world's water consumption is indeed consumed by irrigation (UNEP, 2009; 20I0). Riparian vegetation helps buffer erosion, prevents and mitigates agricultural run-off, while trees, shrubs and plants are crucial in hindering erosion of hill slopes and the loss of nutrients.

Meandering rivers and wetlands serve not only to slow speed of water, but also to allow gradual sedimentation of organic matter, sediments and create spawning habitat for fish and habitats for amphibians and reptiles, insects and birdlife. Wetlands have been estimated to provide ecosystem services of a value of around 5,000-20,000 USD/ha/year (Costanza et al., I997; Zhao et al., 2005; both in 20I0 USD) or globally over 6,6I5 trillion USD per year.

In some regions, diversion of water for agricultural and other purposes has reduced river flow to drylands, coastal areas, with severe impacts on these drylands, coastal habitats and estuarine-dependent species. For example, damming of the Colorado River has drastically changed what used to be an estuarine system into one of high salinity and reduced critical nursery grounds for many commercially important species including shrimp (Aragón-Noriega and Calderon-Aguilera 2000).There are many well-documented examples where diversion of water for agriculture has degraded and reduced the extent of inland water bodies (e.g. Aral Sea and Tarim river, China)(UNEP, 2004), affecting fish spawning and migration and causing a collapse of the fishing industry and a loss of species diversity (MA 2006). Intensifying agriculture also erodes ecosystem services: From I961 to I999 the area of land under irrigation nearly doubled; the use of nitrogenous and phosphate fertilizers increased by $638 \%$ and $203 \%$, respectively, and the production of pesticides increased by $854 \%$ (Green et al. 2005), and improving irrigation efficiency is crucial to restoring ecosystem services (Crossman et al., 2010).

Restoration towards securing water supply and filtering must, however, not only take into account trees and riparian vegetation, it must also address the naturally occurring species and 


\section{Mine Restoration, New Jersey, USA}

Princeton Hydro staff developed a design for the re-vegetation of the mine and the restoration of a 25-acre Coastal Plain wetland in Salem County, NJ. Of the 25 acres of wetland to be restored, 17 acres were mined for over 20 years and an estimated 4 million cubic yards of gravel and clay were removed.

Project and photos credit: Princeton Hydro.
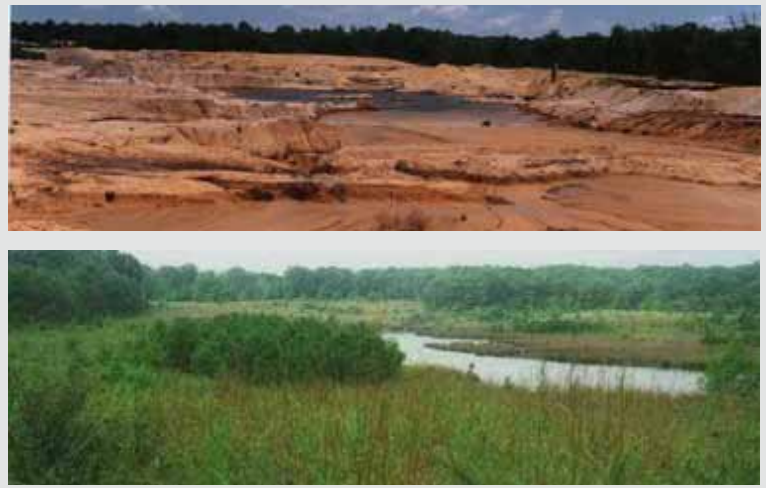

\section{CASE STUDY \#11}

\section{Restoring vegetation, forest and water resources from abandoned Bauxite Mines in Western Australia}

Alcoa World Alumina Australia operates two bauxite mines at Willowdale and Huntly in the Darling Range of southwestern Australia, 80-140 kilometers south of Perth. The mine pits range in size from one hectare to tens of hectares. Alcoa has been rehabilitating its bauxite mines since 1966; today some 550 hectares are mined and rehabilitated
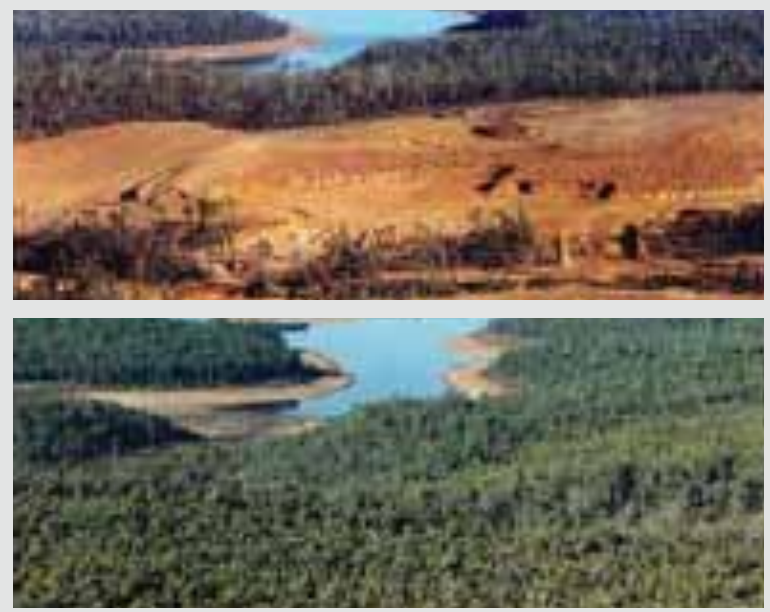

annually. The technology of rehabilitation has been improved continuously over the years - from plantations of exotic pine trees to a sophisticated state-of-the-art rehabilitation program. Alcoa's aim after bauxite mining in these areas is to re-establish all the pre-existing land uses of the forest: conservation, timber production, water production and recreation. Re-establishing a jarrah forest on the mined areas that is as similar to the original forest as possible was determined to be the best way to achieve this goal.

Some 200 million USD were invested from 1996-2007 and over 10,500 ha were restored. The restored jarrah forest has high conservation and biodiversity value and is the basis of a major sawmilling industry, and is widely used for recreation pursuits.

Alcoa has been successful in reaching its goal. In 2000, the company documented that, on average, $100 \%$ of the indigenous plant species found in representative jarrah forest sites would also be found in a 15-month-old rehabilitation, with at least $20 \%$ of those found being from a recalcitrant species priority list. The goal now is to maintain this good record and thus the botanical richness of mined areas after mining operations have ceased.

Source: SER, 2010 www.globalrestorationnetwork.org/database/case-study/?id=141 


\section{Restoration of Flood Meadows along the northern Upper Rhine}

Flood-meadows (alliance Cnidion) are one of the most endangered plant communities in Central Europe. Many species typical to these meadows are already extinct or close to extinction in the project area. This process was accelerated by intensified drainage, structural changes in agriculture and a series of dry years during the 1970 s and 1980 s which further accelerated the conversion of the alluvial grassland into arable fields. As a consequence, many rare and endangered river corridor plants are restricted to small remnant populations in a few permanently non-intensively managed meadows as well as to the fringe of an extensive system of drainage ditches. In general, flood meadows are of high biodiversiy conservation value. Certain types of these meadows (e. g. alliance Cnidion) are protected by the Fauna Flo- ra Habitat Directive of the European Union (92/43/ECC). Due to the distribution patterns of Cnidion-meadows in Central-Europe, Germany has a high responsibility for the conservation of this meadow type. Starting in the mid 80 s large areas (ca. 400 ha) along the northern Upper Rhine where left to passive restoration with the aim to re-establish riparian forests and species-rich flood plain meadows on former arable land. Even after 20 years the grassland that developed from the former arable land is still characterised by rather common grassland species while species and plant communities typical to river corridors are still missing at most restoration sites. Most likely this is due to seed and dispersal limitation of many species under present-day conditions along strongly confined rivers in Central Europe.

\section{CASE STUDY \#13}

\section{Kent Dam River Restoration - Kent, Ohio, USA}

A 1999 Total Maximum Daily Load (TMDL) study conducted by the Ohio Environmental Protection Agency (OEPA) identified water quality problems in the Cuyahoga River behind Kent Dam in the City of Kent, Ohio. A feasibility study was conducted to evaluate alternatives to meet water quality objectives in the TMDL report while also addressing concerns raised by the Kent community. It was agreed that the design should modify the Kent Dam/Dam Pool and restore the Cuyahoga to a free flowing reach alongside the dam. The river flows through this channel

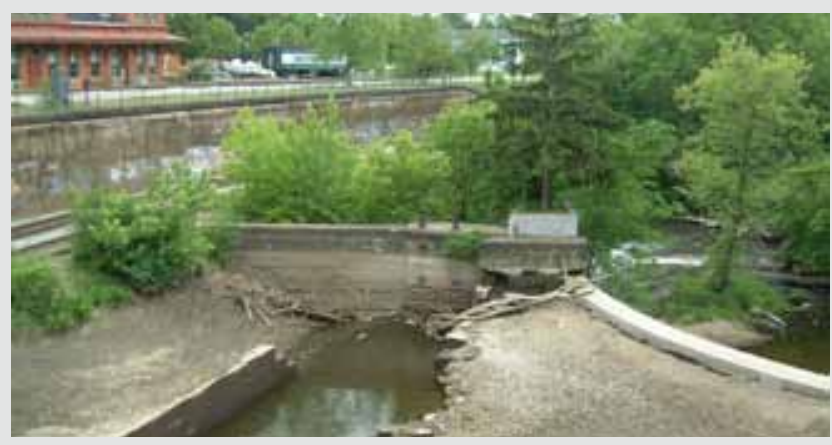

to satisfy OEPA aquatic habitat and fish passage criteria, as well as enhancing amenity and recreational values including opportunities for kayak/canoe passage through the stretch of river and bank revegetation upstream of the dam. Construction for the Kent Dam restoration project was completed in early 2004 satisfying all initial OEPA objectives and providing a center of gravity for urban renewal in the town of Kent, Ohio.

Source: Biohabitats, www.biohabitats.com

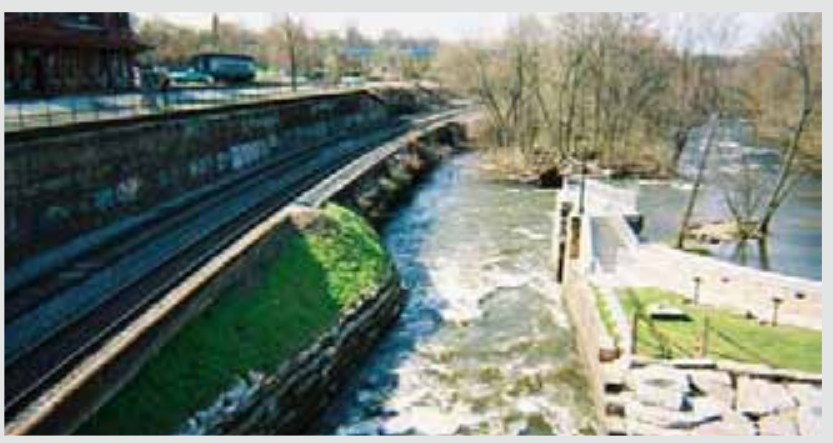




\section{Freshwater and wastewater cycle}

Water withdrawal and pollutant discharge

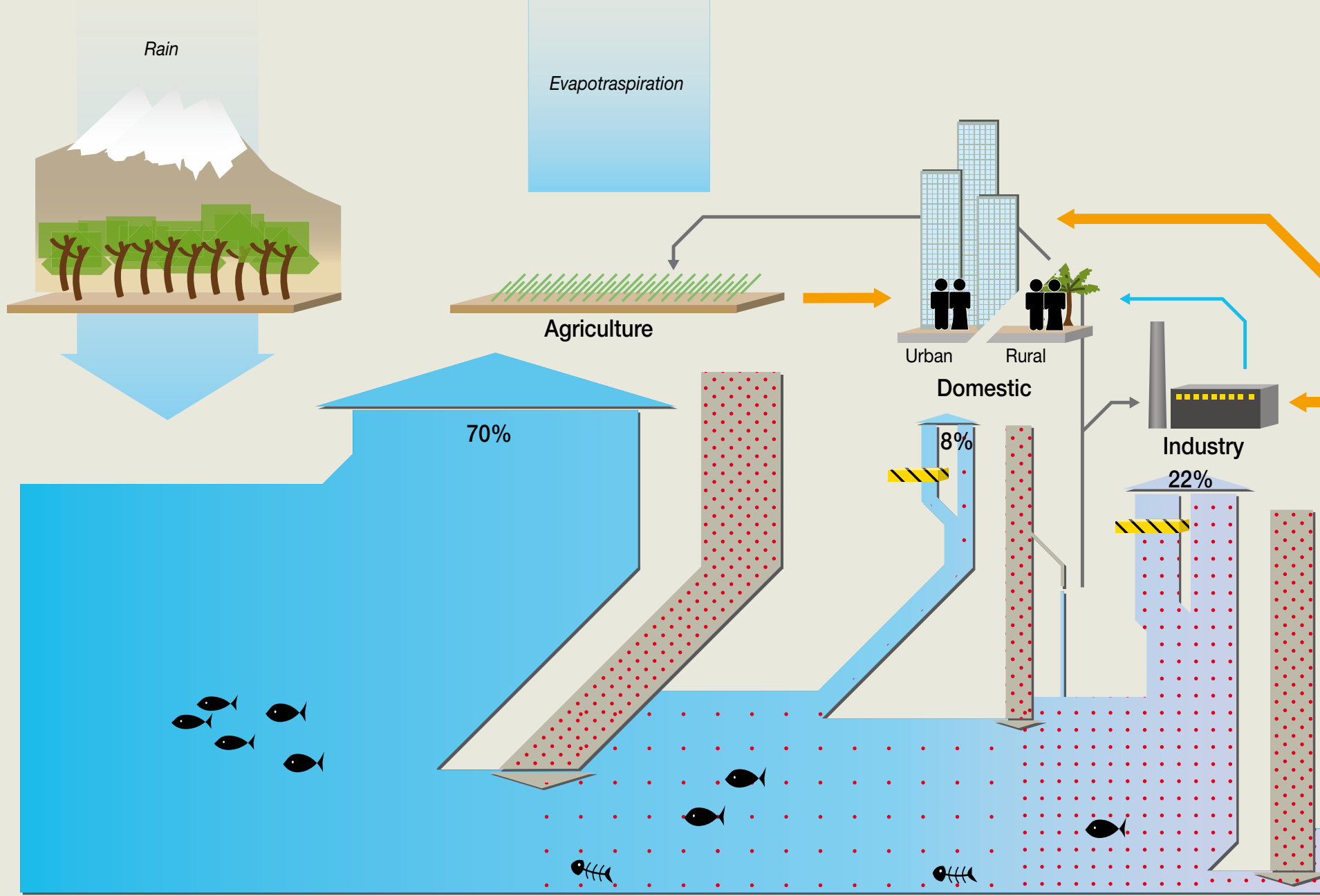

Sources: WHO; FAO; UNESCO; IWMI. 
Figure 8: As water is extracted and used along the supply chain, both the quality and quantity of water available is reduced. flora and fauna that are crucial in the natural cycling of these ecosystems, thus ensuring their long-term function. Indeed, many rivers are straightened and wetlands and marshes drained or dried out behind dikes to ensure agricultural expansion, however, this invariably causes higher water velocity, higher risk of floods, and increased organic pollution further downstream (Bruijnzeel 2004; UNEP, 2005). These ecosystems also help buffer global climate change (Nepstad 2007). Hence, restoration must not address the catchments in terms of forests and riverine vegetation including ground layer, but must also ensure the natural meandering pathways and the flood marshes and wetlands to ensure proper filtration and buffering mechanisms against extreme flows. Worldwide, nearly 900 million people still do not have access to safe water (UNDESA 2009)

Restoration to re-establish diverse grazing and cropping systems, partially restoring naturally supplementing plants and trees in more diversified cropping and grazing systems, combined with green technology in irrigation efficiency, could help drastically reduce the $70-90 \%$ of the water currently consumed and partly wasted by agriculture. This, in turn, would increase water availibility to cities, improve water quality, as well as make more water available for irrigation. Such cropping systems capture more water through wetlands, marshes and lakes during flood seasons, rather than this causing floods and marine pollution as a result of seasonally extremely high velocity and volume. This is particularly important for countries like Pakistan, where a near doubling in population from I84 million people in 2010 to a projected 335 million people by 2050 (UN population division, 2007) - and already facing water scarcity and flood challenges. Pakistan is one of many states that will need to address new ways to secure sufficient water supply for upholding food security in the future.

Restoration is financially viable (TEEB, 2009): Cities like Rio de Janeiro, Johannesburg, Tokyo, Melbourne, New York and Jakarta all rely on protected areas to provide residents with drinking water. They are not alone - a third of the world's hundred largest cities draw a substantial proportion of their drinking water from forest protected areas (Dudley and Stolton 2003). Forests, wetlands and protected areas with dedicated management actions often provide clean water at a much lower cost than man-made substitutes like water treatment plants for example in Venezuela: the national protected area system prevents sedimentation that if left unattended could reduce farm earnings by around USD 3.5 million/year (Pabon-Zamora et al. 2008). 


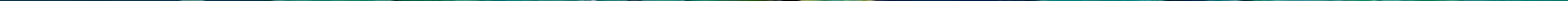




\section{ECOSYSTEM RESTORATION FOR HEALTH AND WASTE WATER MANAGEMENT}

Over half of the organic water pollution and initial wastewater production takes place outside of cities - largely a result of loss of wetlands, increasing erosion and run-off resulting from clearing of natural vegetation along field edges, streams, villages and slopes due to activities such as deforestation, overgrazing and intensive or unsustainable agriculture (UNEP, 20I0). Restoration of wetlands to help filter certain types of wastewater can be a highly viable solution to wastewater management challenges (Ko et al., 2004). Forested wetlands treat more wastewater per unit of energy and have a 6-22 fold higher benefit-cost ratio than traditional sand filtration (Ko et al., 2004).

Securing safe water and reducing the unregulated discharge of wastewater are among the most important factors influencing world health. WHO estimates that worldwide some 2.2 million people die each year from diarrhoeal disease, $3.7 \%$ of all deaths and at any one time over half of the world's hospitals beds are filled with people suffering from water related diseases (UNDP 2006). Of the I0.4 million deaths of children under five, I7 \% are attributed to diarrhoeal disease, i.e. an estimated I.8 million under-fives die annually as a result of diarrhoeal diseases (UNEP, 20I0). Unmanaged wastewater is a vector of disease, causing child mortality and reduced labor productivity, but receives a disproportionately low and often poorly targeted share of development aid and investment in developing countries.

However, while there is some increased focus on the need for treatment plants and operational maintenance over time (UNEP, 20IO; UN-HABITAT, 20IO), the role of ecosystem restoration has sofar not received the attention it deserves - while providing the most viable operational, practical, cheapest and most effective solution for improving water quality in rural areas and into urban centers.
Wetlands, river deltas, lakes and marshes play a crucial role not only in sedimentation of pollutants and organic matter, cultures and harvest of fish and provision of nesting or feeding habitat for birdlife all across the planet, they also serve as important filters for pollutants. Intensive management to increase agricultural production - through irrigation and the application of fertilizers and pesticides - can further reduce the water quality available for consumption. Such intensification has had major direct impacts on biodiversity, such as on farmland birds and aquatic species, but also on algae blooms and water quality, and in return, on people's health.

Run-off from agricultural and livestock production may result in the eutrophication or pollution of aquatic ecosystems (Seitzinger and Lee 2008). Aquatic ecosystems are also being affected by food production in terrestrial areas, mainly through high nutrient input and alteration of freshwater flows. In the NW Gulf of Mexico, nutrient enrichment mainly from fertilizer use in the Mississippi Basin, has accounted for the world's largest hypoxic or dead zone (Turner \& Rabalais I99I, Rabalais et al. I999; UNEP, 2008). Without significant nitrogen mitigation efforts, marine areas will be subjected to increasing hypoxia 


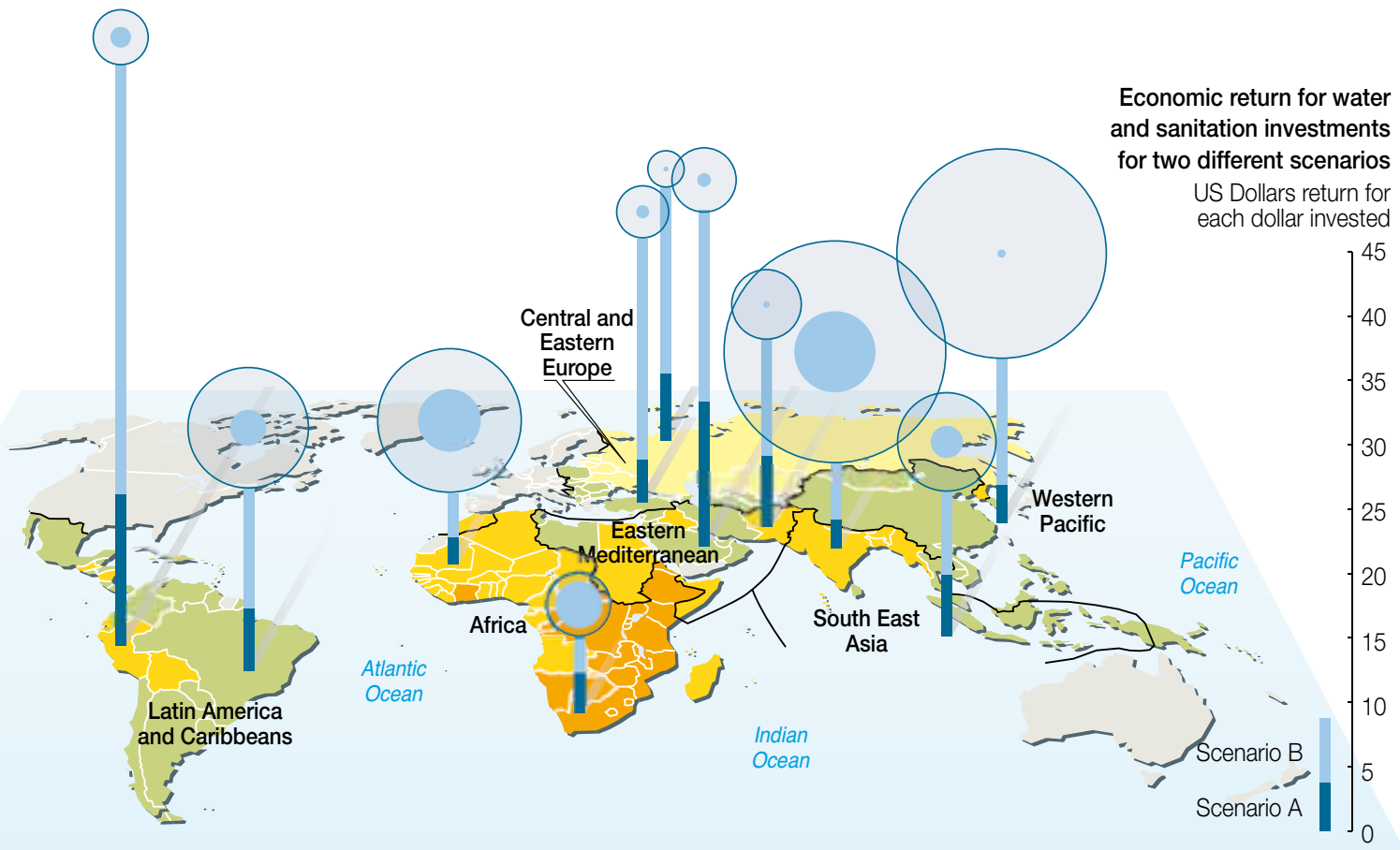

\section{WHO scenarios for 2015}

A Water Source and sanitation for

A the Millennium Development Goals

Regulated piped water

B source and sewer connection

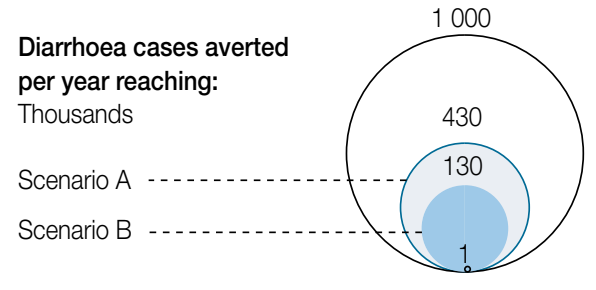
per year reaching: Thousands

Scenario B
Mortality rate for WHO sanitary regions

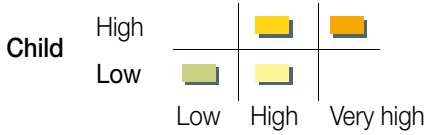

Adult
Source: Hutton, G., et al.. Global cost-benefit analysis of water supply and sanitation

interventions, Journal of Water and Health, 2007.

Figure 9: Wastewater, health and human well being.

and harmful algal blooms that will further degrade marine biomass and biological diversity (Sherman and Hempel 2008; UNEP, 2008).

At least I. 8 million children under five years die every year due to water related disease, or one every 20 seconds (WHO, 2007). Estimates of the global burden of water-associated hu- man diseases provide a simple index hiding a complex reality. For an estimated $88 \%$ of diarrhoea cases the underlying cause is unsafe water, inadequate sanitation and poor hygiene. Moreover, it is estimated that $50 \%$ of malnutrition is associated with repeated diarrhoea or intestinal worm infections. Childhood malnutrition is at the root of $35 \%$ of all global child mortality (WHO, 2007). 


\section{Revegetation of a road cut, Glacier National Park, B.C., Canada}

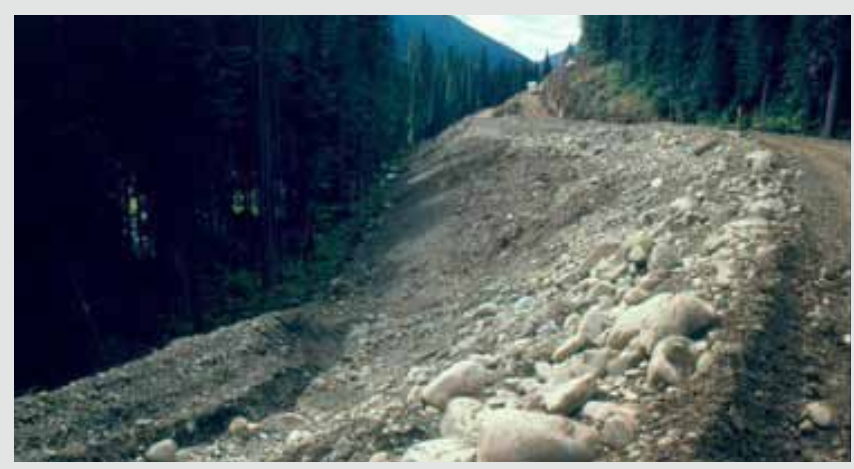

Restoration of a new railroad grade in Glacier National Park BC Canada followed natural successional processes by using a local pioneering species (Alnus viridis ssp. sinuata) as the dominant initial cover.

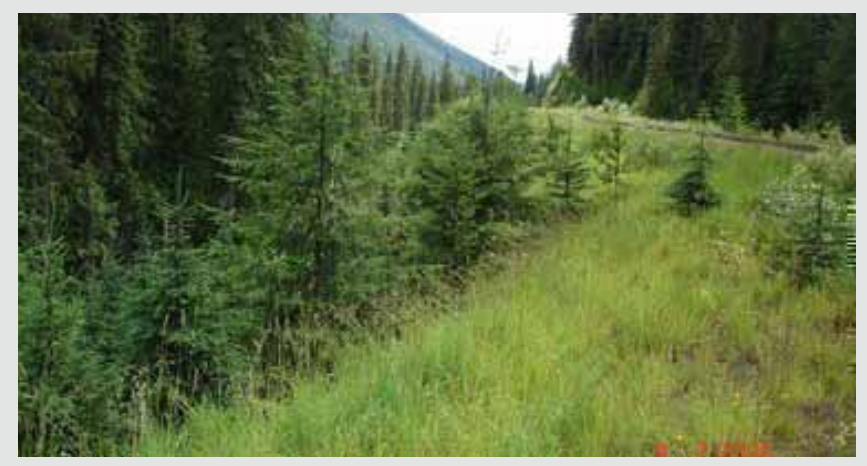

Project and photos credit: Polster Environmental Services.

\section{CASE STUDY \#15}

\section{Ecosystem restoration in the Golden Horn, Turkey}

In the Golden Horn Estuary, at the center of Istanbul, Turkey, over 40 years of uncontrolled industrial and urban growth caused major damage to local water resources in this city of over 11 million people. Filling one-third of the estuarine surface area to establish factories and tenements with no waste provisioning had resulted in thick layers of anoxic sediment, industrial contamination, toxic bacteria, consistently low water clarity, "unusable" dissolved oxygen levels (by US EPA standards), and a strong hydrogen sulfide odor. These unhealthy conditions led to an ecologically unlivable environment, fisheries collapse, and low quality of life. Restoration of the once-again iconic Golden Horn Estuary in Istanbul has been one of the world's largest such projects, given the complexity of the situation and need for a multifaceted, staged approach. This substantial political, logistical, ecological, and social challenge demonstrates the wide-ranging and longterm considerations frequently required for successful restoration. The major components of this rehabilitation, which took place over two decades, included (1) demolition and relocation of industries and homes along the shore, (2) creation of waste- water infrastructure, (3) removal of anoxic sludge from the estuary, (4) removal of a floating bridge that impeded circulation, and (5) creation of cultural and social facilities. This restoration presents a prime example of a developing country ameliorating environmental problems in spite of inadequate management funds, institutions, policies, and legal structure. In this case, reorganizing and strengthening municipal institutions proved critical in reversing the effects of pollution. The sum of these efforts was largely successful in revitalizing the area through dramatic water quality improvement. Consequently, the estuary is once again inhabitable for aquatic life as well as amenable to local resource users and foreign visitors, and Istanbul has regained a lost sense of cultural identity. For more information, see Coleman et al. (2009). The paper focuses on literature review and personal interviews to discuss the causes of degradation, solutions employed to rehabilitate the estuary, and subsequent physicochemical, ecological, and social changes.

Source: Coleman et al., 2009 


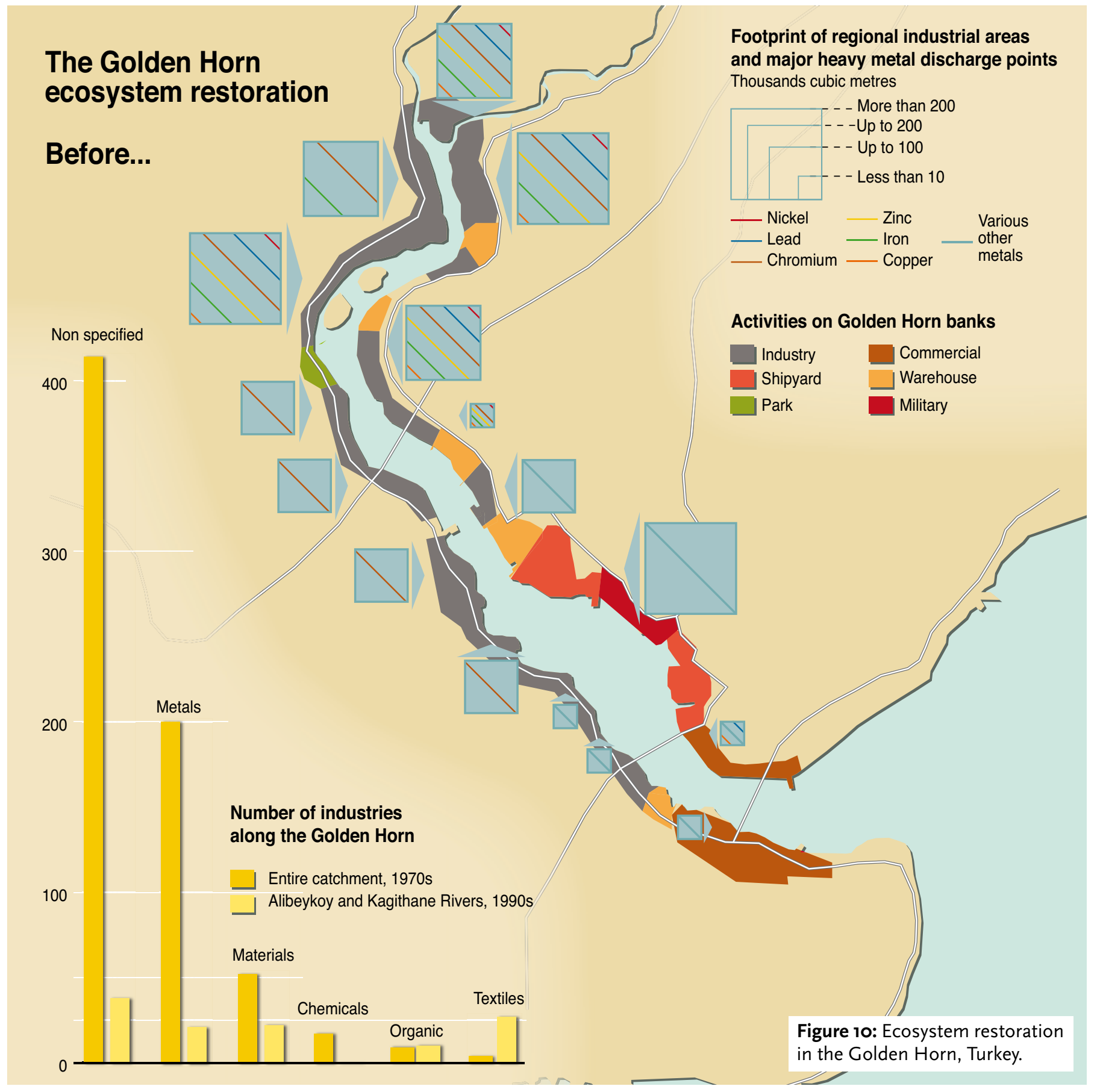




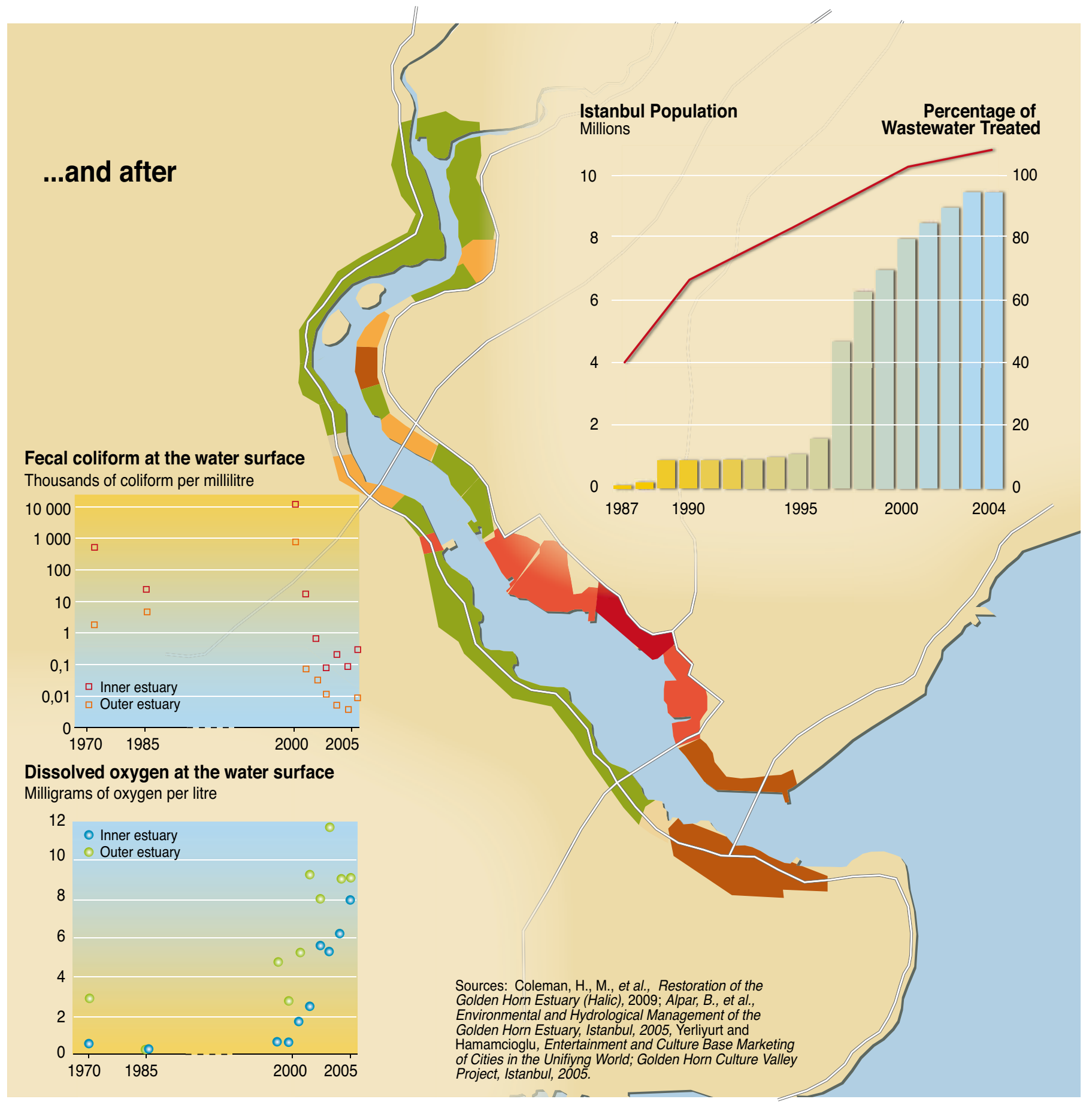




\section{Lake Hong case in the Yangtze: Restoring the Lake Hong for fisheries, biodiversity and water supply}

The amazing scenery of the Lake Hong has described in a classic Chinese ballad, but most people have never seen it. In the 199oies millions of bamboo posts were standing in the Lake for intensive enclosed fishery, some $43 \%$ of the wild fish species were gone or nearly gone, the water was infested and polluted with algae blooms, and the migratory birds vastly gone. More than $70 \%$ of the Lake was fully fenced by fishing nets, and was divided into small farming plots. Consequently, a serious ecological crisis was threatening the Lake Hong: degradation of water quality, loss of aquatic plants, decrease of fishery resources, and loss of biodiversity such as water birds.

With support of WWF-HSBC Programme - Restoring the Web of Life in the Central Yangtze, a wetland restoration demonstration project in the Lake Hong was initiated in 2003. Through tailored interventions, e.g. removing fishing nets, reintroducing local fish species for farming, plantation of aquatic grasses, aquatic vegetation on the pilot area was fully restored, with aquatic grass coverage raising to $80 \%$, water quality improved from Grade $\mathrm{V}$ (for agriculture use only) to Grade II (drinkable after simple treatment). Some rare birds e.g. Purple Swamphen and the globally endangered species Oriental White Stork returned back to the Lake Hong after 20 years absence. Moreover, the incomes of fish farmers participating in the project tripled within three years as a result of improved environmental conditions. Inspired by this successful pilot, in 2005, the Hubei provincial government decided to allocate a budget of near 1 million USD ( 7.3 million RMB) to restore the entire lake by removing all fishing nets and ap- plying other restoration methods. Wintering water birds from the North have returned back to the lake. In 2006, the Lake Hong won the award of The Best Practice of Lake Protection of the Living Lakes Network at the eleventh Living Lake Conference, and was designated as a RAMSAR site by the Chinese government in 2008.

Source: Lifeng Li, WWF International and Gang Lei, WWF China personal communication, 2010.

Photo credits: Zhang Yifei, WWF China.

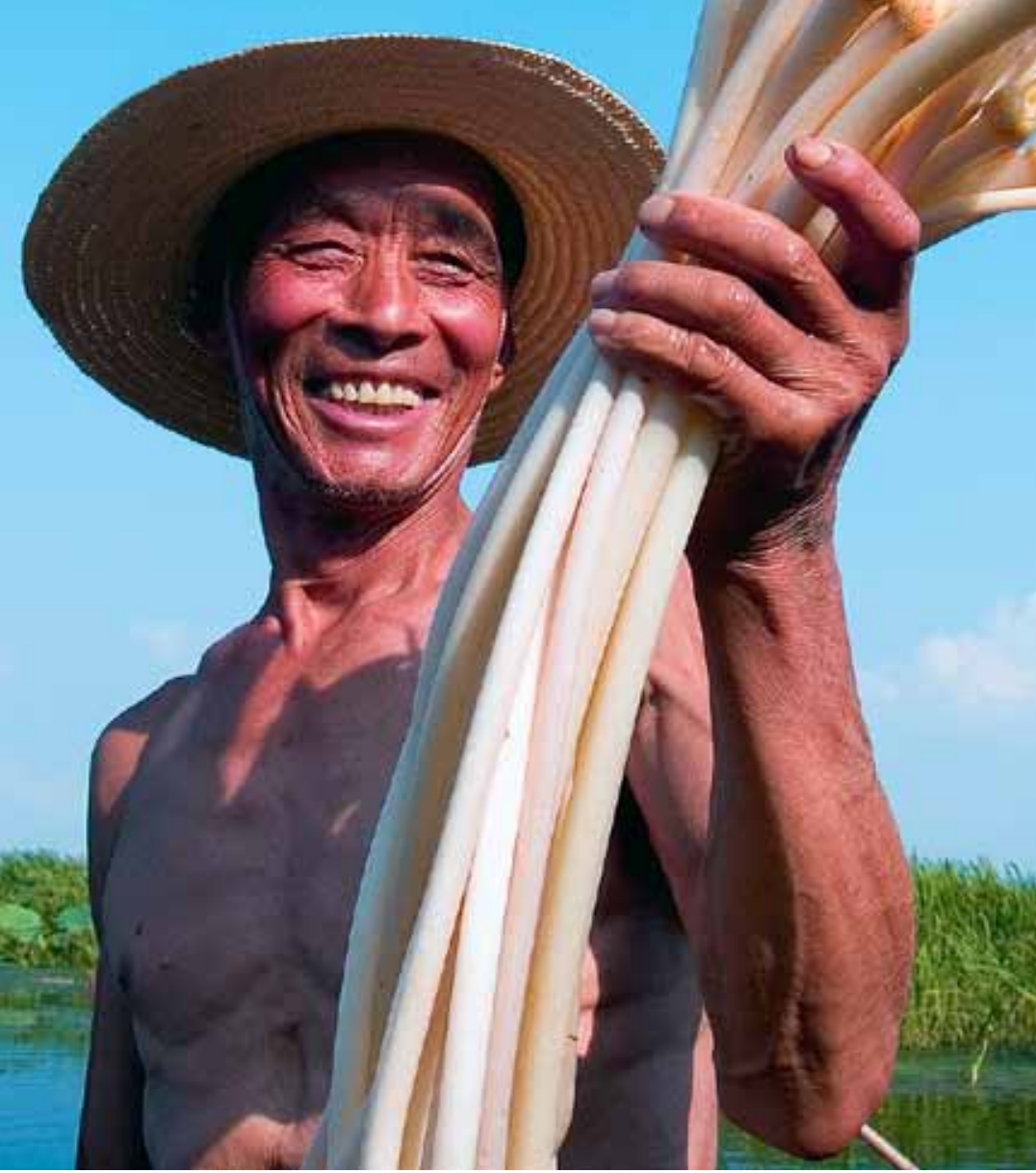




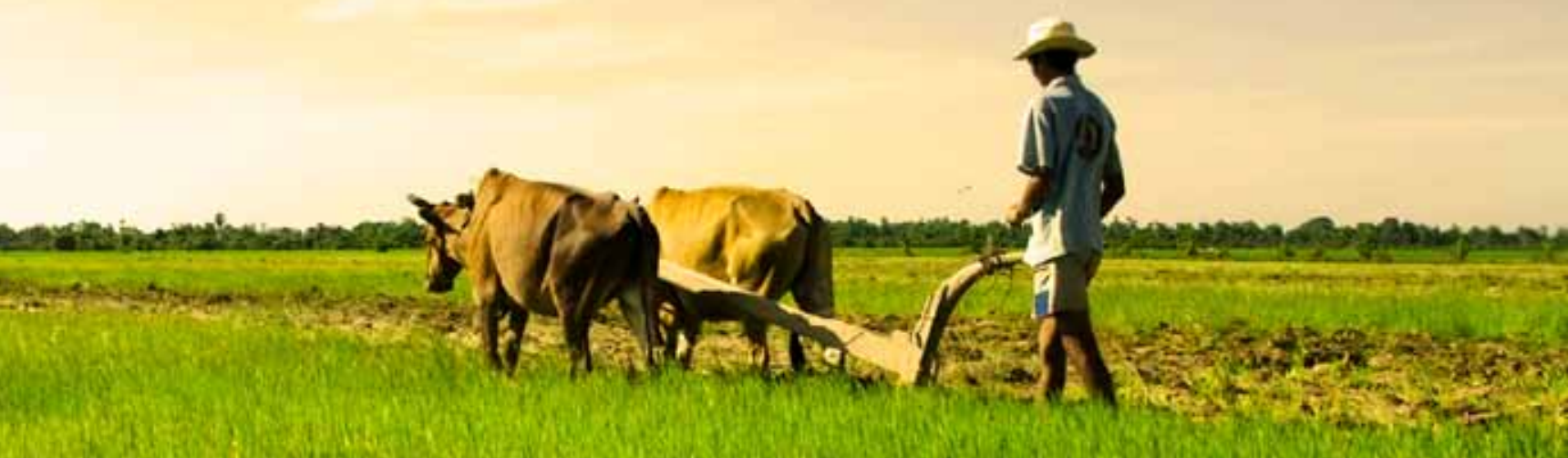

wathese

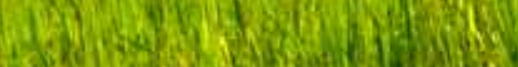

Now

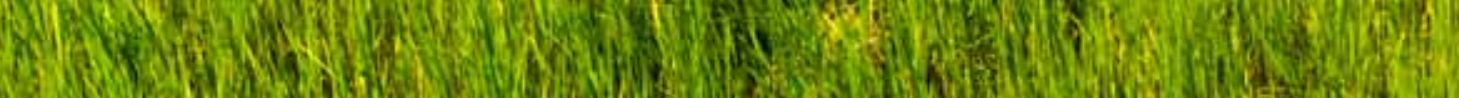

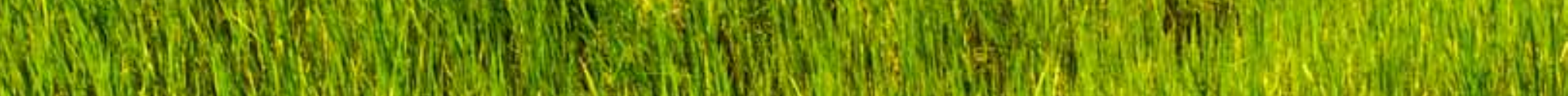

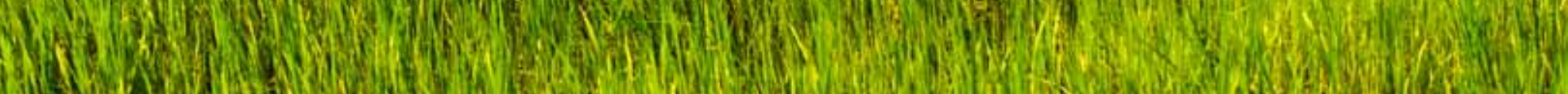

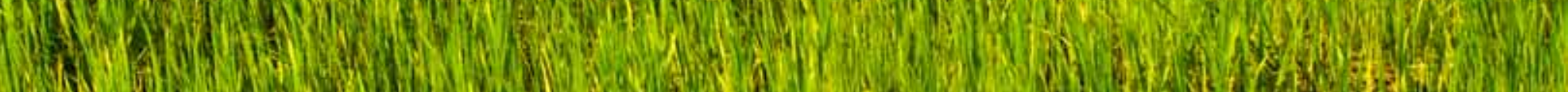
ar and mo wh H.

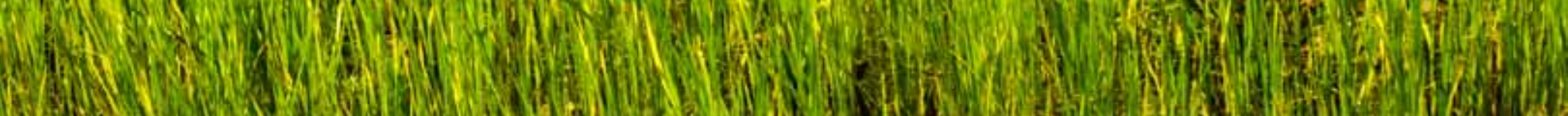
Whe

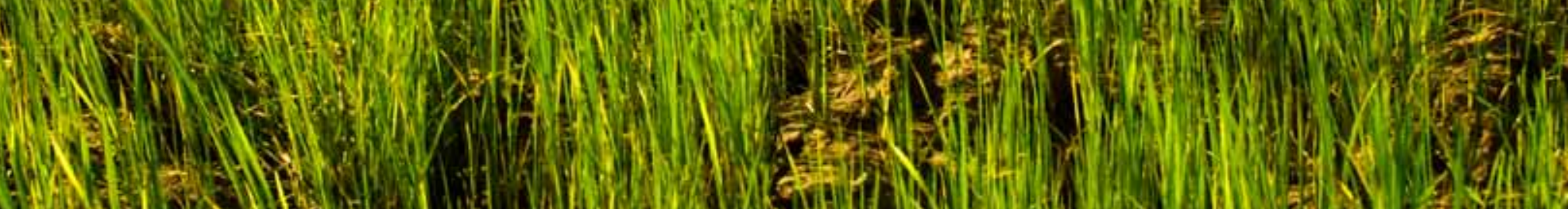

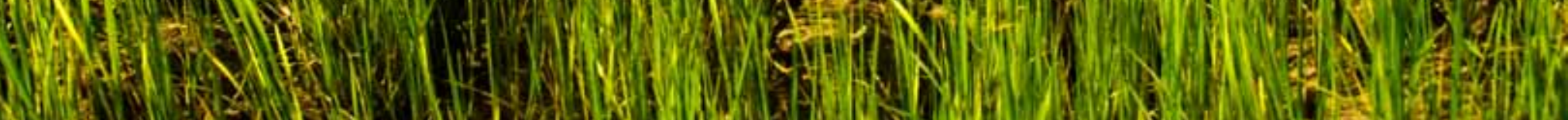

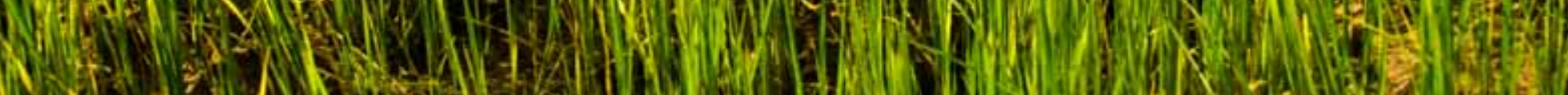
(1) A

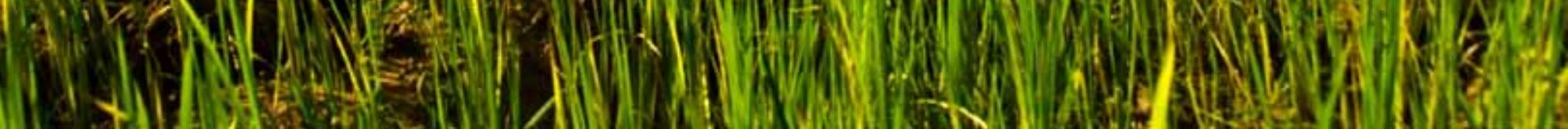




\section{ECOSYSTEM RESTORATION FOR FOOD SECURITY}

Continuing loss of ecosystems services at current rates through land degradation, reduced amount of water for irrigation, nutrient depletion, declining pollination and lower natural pest control such as of invasive species could seriously jeopardize world food production and depress required production by up to $25 \%$ by 2050 (UNEP, 2009). Loss of pollination alone has been estimated to account for a value of $9.5 \%$ of the global agricultural output used for human consumption in 2005 (Allen-Wardell et al. I998; Brown and Paxton, 2009; Gallai et al., 2009). Restoration of ecosystems and reversing land degradation are of particular importance to the impoverished, so dependent upon the environment for their productivity, food security and health (Lal, 2009; UNEP, 2009; Sodhi et al., 20I0).

Restoration for improving food security not only includes land management of forests, ecotones along field edges and streams, but also in supporting more diversified and resilient eco-agriculture systems that provide critical ecosystem services (water supply and regulation, habitat for wild plants and animals, genetic diversity, pollination, pest control, climate regulation), as well as adequate food to meet local and consumer needs (UNEP, 2009; Sandhu et al., 2010). This includes managing extreme rainfall and using inter-cropping to minimize dependency on external inputs like artificial fertilizers, pesticides and blue irrigation water and the development, implementation and support of green technology also for small-scale farmers (UNEP, 2009; 20IO). More efficient irrigation systems can reduce water consumption by $15-20 \%$ without a yield decline (Boumann et al., 2007).

Wild crop relatives (UNEP, 2009) can be important in restoring degraded agricultural lands and genetic diversity is likely to become in creasingly important in future restoration projects.

FAO defines food security as follows: 'Food security exists when all people, at all times, have physical and economic access to sufficient, safe and nutritious food for a healthy and active life (FAO, 2003). This involves four dimensions:
- adequacy of food supply or availability;

- stability of supply, without fluctuations or shortages from

- season to season;

- accessibility to food or affordability;

- utilization: quality and safety of food.

Ecosystems are the very foundation of all agricultural production. UNEP has, in the "Environmental food crisis" (UNEP, 2009), described how environmental degradation may lead to up to $25 \%$ reduction in global food production by 2050 , higher food prices, greater volatility and greater regional inequality, with the greatest impacts on the impoverished and particularly in Africa. Restoring degraded lands is therefore an utmost priority (Lal, 2009).

Restoration for food security must address 5 components mainly: - Restoration to reduce infestations of invasive species, pests and diseases, and restore natural enemies by diversification of production and species and natural habitats along edges and in fields including diversified and resilient eco-agriculture systems, including establishing host-plants for natural predators or active biological control. Indeed, the ecosystem services value of organic compared to conventional farming has been estimated I,6Io-I9,420 USD/ha/year compared to 


\section{Restoration of abandoned plantations, Proyecto Naturaleza y Comunidad, Costa Rica}

The Nogal-La Selva local Biological Corridor (NSBC) is located in Sarapiquí, in the northern Caribbean lowlands of Costa Rica, Central America. The NSBC is an effort which intends to connect forest fragments from the Nogal Private Wildlife Refuge (252 acres), a natural private reserve owned by Chiquita Brands International,

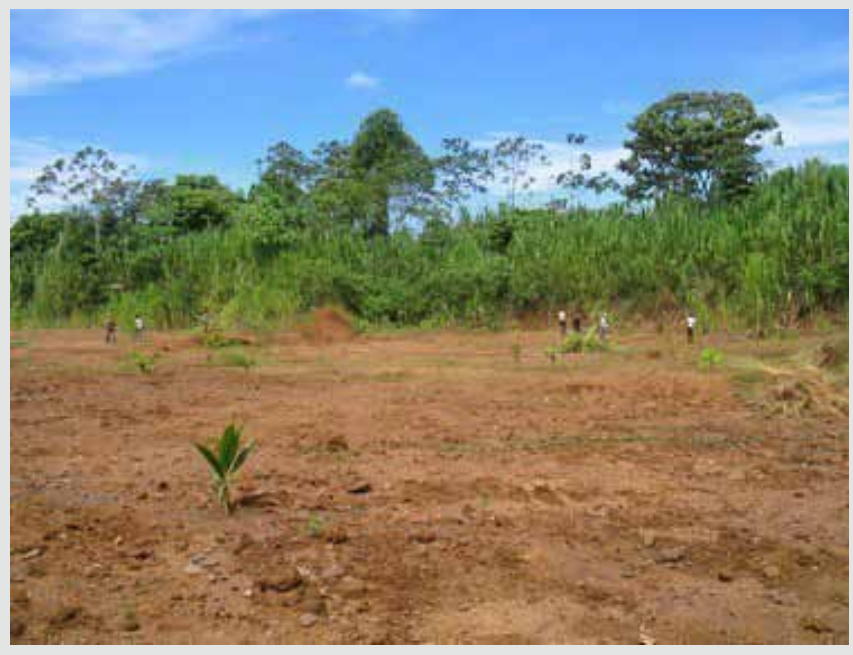

I,270-I4,570 USD/ha/year, or 22-25\% lower for conventional farms. Non-market values were 460-5,240 USD/ha/year for organic farmland compared to only 50-I,240 USD/ha/ year for conventional (Sandhu et al., 2008).

- Restore water supply and reduce effects of extreme flows including droughts and floods by restoring natural pathways, riverine and catchment vegetation and wetlands.

- Reduce evapotranspiration, improve weed control and increase soil fertility and biological life in soils through more organic based production systems, including, where appropriate, perennials (Vieria et al., 2009; UNEP, 2009).

- Reduce sedentary and intensified grazing systems and promote grazing diversity to reduce overgrazing and depletion of range diversity which increases probability of invasive species infestations. to La Selva Biological Station (3,900 acres), an ecological research station owned by the Organization for Tropical Studies (OTS).

Project and photos credit: Chiquita Brands International/GTZ/MIGROS/ Rainforest Alliance

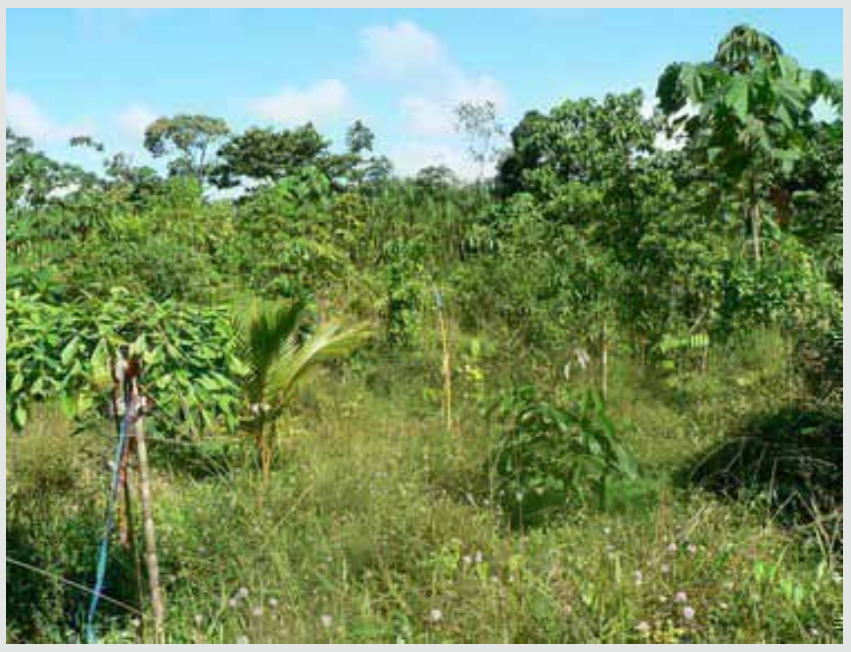

- Develop alternatives to the use of cereals in animal feed by recycling of waste or new technology to reduce the effect that near $\mathrm{I} / 3$ of all cereals are used for animal feed, rising to near $50 \%$ by 2050 , thus reducing the pressures on cropland expansion - both locally into natural edges, as well as into pristine habitats (UNEP, 2009).

Changing the meat consumption habits and developing an alternative to the use of cereals in animal feed is actually a prerequisite necessary for restoring much lost raindforest and wetlands cleared and drained to support cattle production. This demonstrates once again that in restoration one must not only address the restoration of the ecosystem at hand, but also address the socio-economic driving forces that led to degradation in the first place. 
Total agricultural R\&D spending in developing countries increased from USD 3.7 billion (I99I) to USD 4.4 billion (2000), or by $\mathrm{I} .6 \%$ annually (IFPRI, 2008). This spending was largely driven by Asia, where annual spending increased by $3.3 \%$. In Africa, agricultural R\&D expenditure actually declined slightly, by $0.4 \%$ a year. As a result, the regions of the world are sharply divided in terms of their capacity to use science to promote productivity growth to achieve food security and reduce poverty and hunger and in a more sustainable manner including restoring pest or weed infested lands.

Invasive alien species are now thought to be the second-gravest threat to global biodiversity and ecosystems next to habitat destruction and degradation (Mooney et al., 2000; CBD, 200I; Kenis et al., 2009). The steady rise in number of alien species is predicted to continue under many future global biodiversity scenarios (Sala et al., 2000; Gaston et al, 2003; MA, 2005), although environmental change may also cause non-alien species to become invasive. Environmental change, (for example rising atmospheric $\mathrm{CO}_{2}$, increased nitrogen deposition, habitat fragmentation and climate change) may facilitate further invasions (Macdonald, I994; Malcolm et al., 2002; Le Maitre et al., 2004; Vilà et al. 2006; Song et al., 2008). As invasive or foreign species compose over 70\% of all weeds in agriculture (estimated in the USA)(Pimentel et al., 2004), a continued growth in invasive species poses a major threat to food production (Mack et al 2000; MA, 2005; Pimentel et al., 2005; Chenje and Katerere, 2006; van Wilgen et al, 2007).

Restoration attempts will need to address causes for the spreading, ranging from the marine spilling of ballastwater in shipping containing numerous exotic and even invasive marine species (UNEP, 2007) to spreading with land transport, to addressing pollution, landuse patterns and socio-economic variables influencing the initial loss of the ecosystems involved (King et al., 2009). In many cases, re-establishing partial natural cycles, such as storm-burning reducing invasive species like Melaleuca viridiflora on grasslands, but leaving fire-adapted vegetation, could help reduce such invasive pests (Crowley et al., 2009). It is also very well known from agriculture that re-establishment of ecotones or restoring diverse field edges significantly influences the survival of natural pest controlling insects, birds, or that biological control systems (Zhang and Swinton, 2009). This includes among other introducing insects, pathogens, enzymes or establishing natural host plants for pest-predators can effectively reduce infestations such as for example in coffee (Batchelor et al., 2005); tea (Todokoro and Isobe, 20I0), banana (Ting et al.,

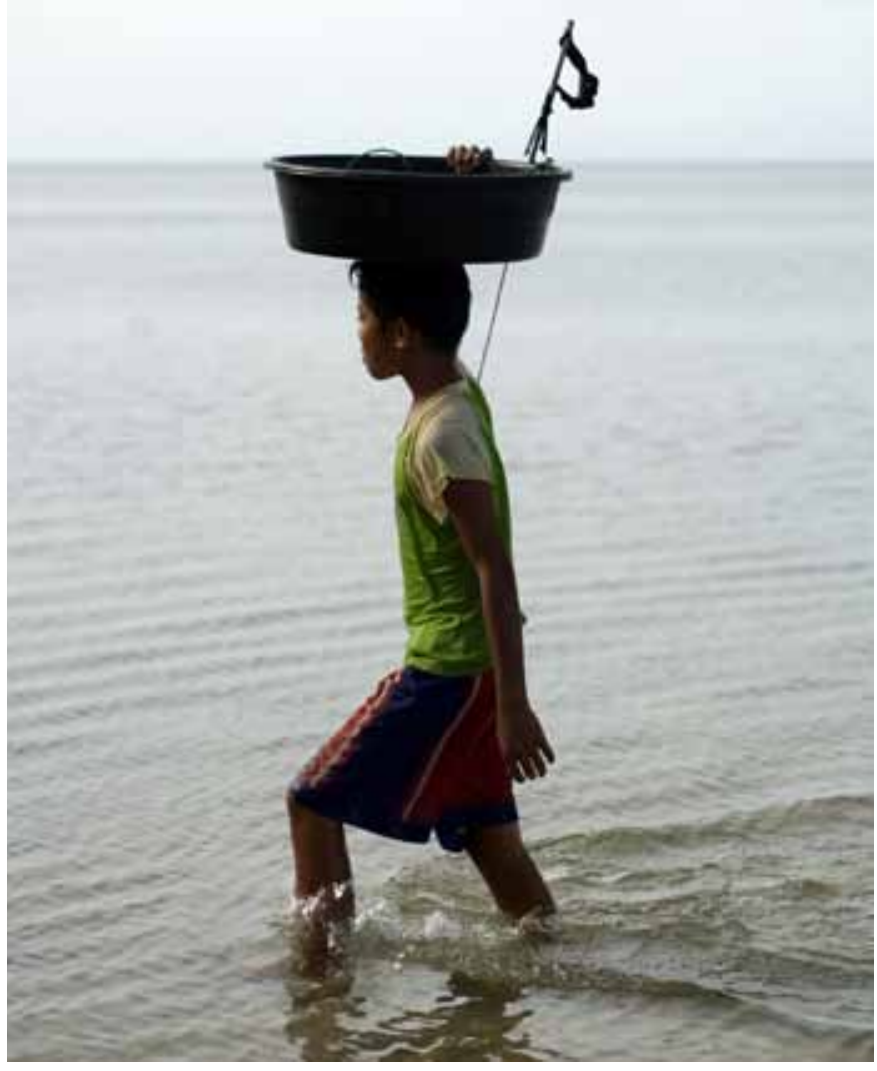

20I0) and mango production (Braimah and van Emden, 20I0). Insects or insect-borne diseases in biological control, such the transmission of a pathogenic virus carried by an eriophyid mite Phyllocoptes fructiphilus to control the weed Rambler rose (Rosa multiflora) infesting grazing ranges in China, Japan and Korea, have also proven effective (Smith et al., 20I0).

Restoration is also crucial in relation to maintaining soil fertility, restoring degraded soils and reducing compaction (Batey, 2009; Lal, 2009; UNEP, 2009).

It is therefore clear that restoring ecosystem services can involve quite complex measures. Ecosystem services are therefore essential parts of the benefits in more organic or diversified ecoagricultural based systems (UNEP, 2009; Sandhu et al., 2010). 


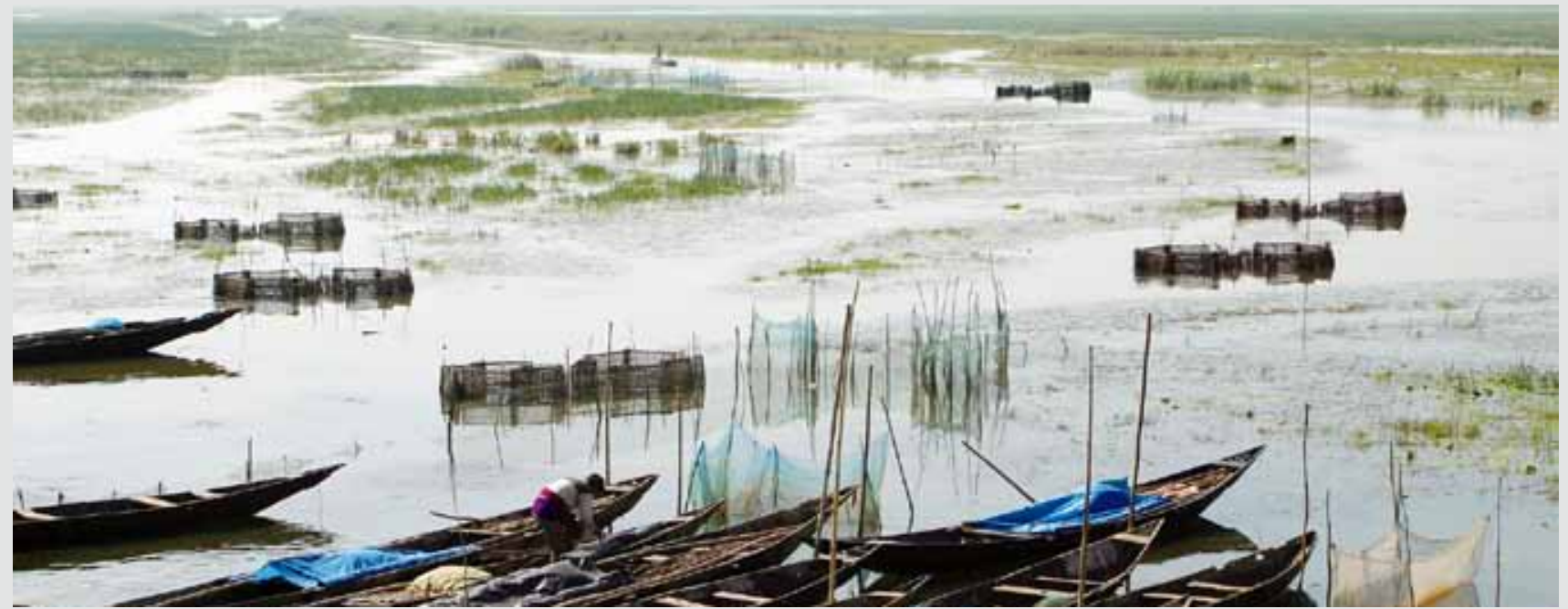

\section{Chilika Lake - from Montreaux record to Ramsar Conservation Award}

Lake Chilika spanning between $906-1,165 \mathrm{~km}^{2}$ is the largest coastal lagoon on the east coast of India. It is a hotspot of biodiversity and harbours several endangered and endemic species including those listed under the Red List. Over one million migratory birds commonly winter here. It is also one of only two lagoons in the world that support Irrawaddy Dolphin populations. The diverse and dynamic assemblage of fish, invertebrate and crustacean species found within Chilika provide the basis of a rich fishery which supports over 200,000 local fisherfolk and generates over $6 \%$ of the state's foreign revenue.

Chilika underwent rapid degradation during 1950 - 2000 owing to increasing sediment loads from degrading catchments and reduced connectivity with the sea. As salinity declined, the lake fisheries went down by over $80 \%$ during $1985-2000$, along with an increase in area under invasive weeds and shrinkage in area and volume of the lake. This had tremendous impact on the livelihood of communities, especially fishers who depended on lake for sustenance. The lake was put under Montreaux Record of the Convention in 1993. Realizing the problems of Chilika Lake, Government of Orissa created the Chilika Development Authority (CDA) in 1992 for restoration of the ecosystem. CDA undertook several measures for lake remediation including catchment area treatment, hydrobiological monitoring sustainable development of fisheries, wildlife conservation, ecotourism development, community participation and development and capacity building at various levels. In 2000, CDA in partnership with Wetlands International and a network of organizations carried a major hydrological intervention by opening a new mouth to the Bay of Bengal which helped improve salinity levels, enhanced fish landing, decrease of invasive species and overall improvement of the lake water quality. The initiative rejuvenated the lake ecosystem and improved livelihoods of communities dependant on its resources for sustenance. Based on the restoration measures undertaken, the Government of India requested the Ramsar Convention Bureau to consider removal of Chilika Lake from the Montreaux Record. The lake was finally removed from the Montreaux Record in 2001 and the restoration recognized with a Ramsar Award to the CDA in 2002. As per assessments in 2009-10, lake fisheries stood at 11,955 MT. Additionally, 158 dolphins were counted and over 0.9 million waterbirds used the lake as habitat.

CDA and WISA are currently designing an integrated plan to ensure effective management practices for the lake conservation and providing economic incentives to stakeholders through coordinated actions at river basin level integrating coastal processes.

Source: Wetlands International, Personal communication, 2010 


\section{Rock Creek and Ignacio Creek Stream Restoration, La Plata County, Colorado, USA}

The effects of overgrazing near southwestern Colorado's Rock Creek resulted in major erosion with banks up to eight feet high in some places. Biohabitats has conducted a feasibility study with the Southern Ute Indian Tribe to address this problem through a series of four projects along the creek including bank stabilization, habitat and re-vegegation.

Sequential project phasing accommodated funding cycles and provided opportunities to modify and improve restoration techniques. These projects were dependent on successful engagement and collaboration with the tribal community and volunteers. To ensure local cultural and environmental relevance of the solution required modification of methods and approaches, selection of appropriate materials and species. Work is continuing to work with the Tribe's water quality department on the restoration of nearby Ignacio Creek.

Source: Biohabitats, www.biohabitats.com
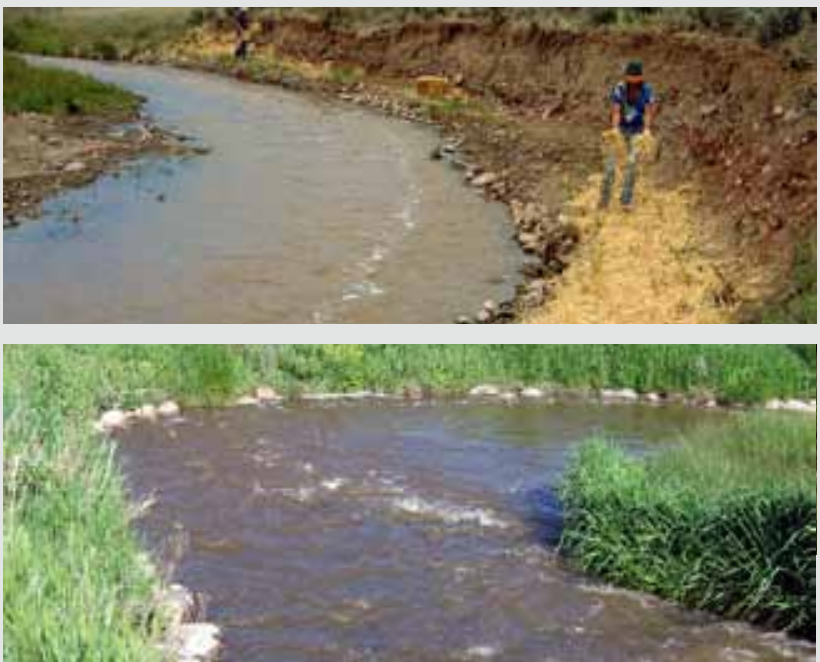

\section{CASE STUDY $\# 20$}

\section{Enhancing sustainability through the use of crop wild relatives}

Crop wild relatives - species or other taxa more or less closely related to crops, that include most of the progenitors of our domesticated types - have made an extremely significant contribution to modern agricultural production through the characteristics that they have contributed to plant cultivars.

Over the last 100 years crop wild relatives have become increasingly important as sources of useful genes. For example, they have contributed pest and disease resistance (e.g. resistance to late blight in potato and grassy stunt virus in rice which came from a single accession of Oryza nivara found in Orissa, India) and abiotic stress resistance. They have also increased nutritional values such as protein and vitamin content. The economic returns from investment in CWR can be striking; for example, genetic material from a tomato wild relative has allowed plant breeders to boost the level of solids in commercial varieties by $2.4 \%$, which is worth USD 250 million annually to processors in California alone (FAO, 1998).
The natural populations of many crop wild relatives are increasingly at risk. They are threatened primarily by habitat loss, degradation and fragmentation. Moreover, the increasing industrialization of agriculture is reducing populations of crop wild relatives in and around farms. They are often missed by conservation programmes, falling between the efforts of agricultural and environmental conservation actions. A major global effort, coordinated by Bioversity International and supported by UNEP GEF to find ways of securing the improved conservation of crop wild relatives is in progress in 5 countries (Armenia, Bolivia, Madagascar, Sri Lanka and Uzbekistan) in collaboration with a number of international agencies (FAO, UNEP-WCMC, IUCN, Botanic Gardens Conservation International - $\mathrm{BCCl}$ ). Restoring wild crop relatives and using them in restoration has sofar received little attention, but may be crucial in order to meet future food insecurity in a changing environment.

FAO, 1998. The State of the World's Plant Genetic Resources for Food and Agriculture. FAO, Rome. (Adopted from UNEP, 2009: The environmental food crisis). 


\section{Shellfish Reefs United States oyster restoration case study - enhancing fisheries}

Shellfish reefs - physical habitats built by the accumulation of masses of mollusk shells - may be the world's most threatened marine habitats. Once widespread in estuaries and lagoons, a conservative estimate suggests that $85 \%$ have been lost to overfishing, poor river basin management and pollutionı (Beck et al., 2009).

The value of shellfish for food has been recognized for millennia, however it is only in recent decades, as the resources have become scarce, that other services provided by shellfish reefs have been realized. Through their complex structure, shellfish reefs greatly enhance commercially important fish and crab stocks. In sufficient quantities they can measurably reduce nitrates and turbidity in coastal waters. In so doing they also allow growth and recovery of other important habitats such as seagrasses. In some locations the large physical structures of shellfish reefs even protect coasts from wave action. Such services are of growing social, economic and political relevance as pollution and sea level rise are of increasing concern world-wide.

In the US, recognition of these valuable services has led to a surge in interest in the restoration of oyster reefs nation-wide. The federal National Oceanic and Atmospheric Administration, through numerous partnerships, has supported over 128 oyster and shell bottom restoration projects in twenty states since 1998. Many other restoration efforts have been undertaken by state agencies, NGOs and community groups.

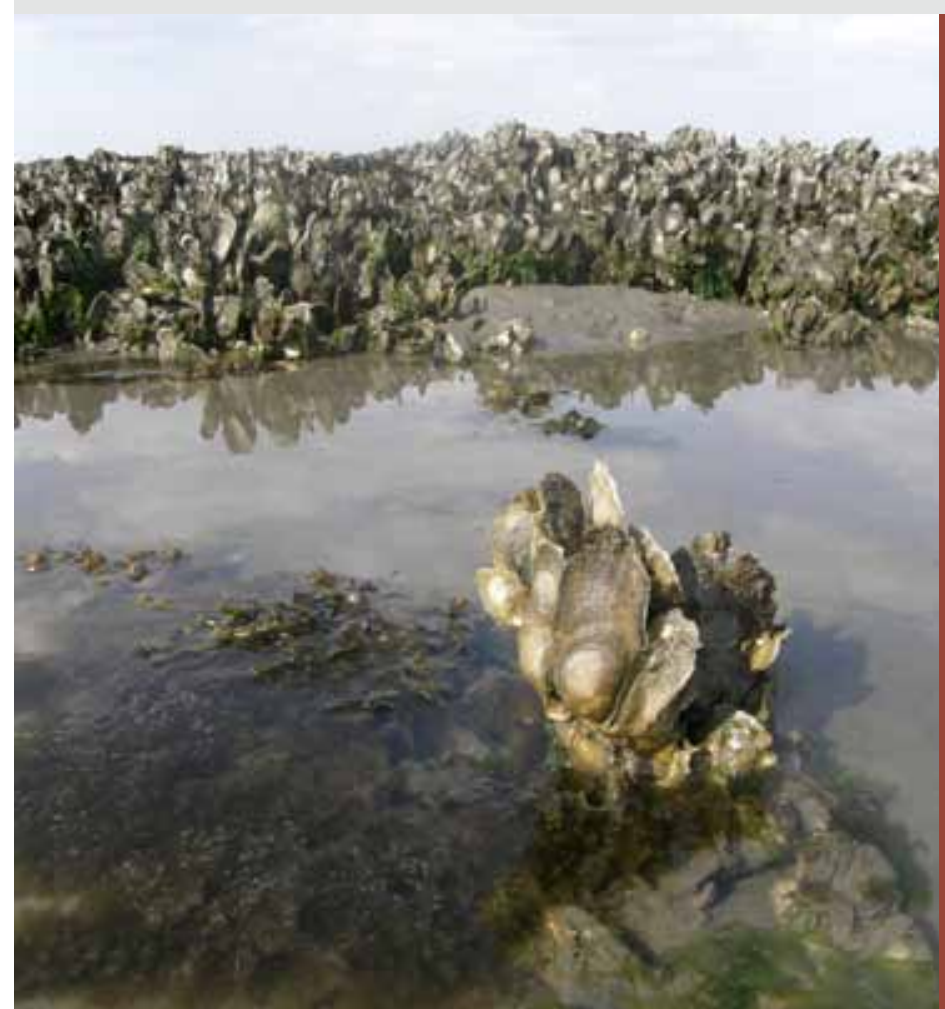

\section{Virginia Coast restoration sites}

Communities on the east Virginia coast have a long history of oyster harvesting, however the eastern oyster Crassostrea virginica finally became commercially extinct in the region in the early 1990's. In 2006 a public-private community partnership was formed between the Virginia Marine Resources Commission and The Nature Conservancy which, in collaboration with local businesses and community volunteers, made significant steps to restoring oyster reefs in Smith Island Bay. Local contractors dredged over 1188 tonnes of fossil shell, depositing them in shallow areas to form two $\sim 0.8$ ha reefs. The rapid colonization and growth of new oysters on the reefs has catalyzed further restoration projects. To date the larger Seaside Bays Restoration Project on the Virginia Coast, of which Smith Island Bay is a part, has successfully restored 1.7ha of intertidal oyster reef, with a further 5.5 ha planned. An estimated 47 jobs will be maintained or created by oyster restoration work as a result of this project.

Virginia Coast restoration sites are continually monitored, and have been showing significant recruitment since their construction. Research is being undertaken to determine the filtration 
A critical precursor to restoration has been to establish secure management to prevent degradation or loss of restored areas. This has been achieved though the establishment of legal sanctuaries, and through private ownership or leasing of intertidal and subtidal lands. A broad range of restoration techniques have been developed and tested. Where recovery is limited by habitat availability (young oyster "spat" need to settle on hard substrates), restoration techniques focus on the provision of "cultch", or areas of hard bottom. Elsewhere, where recruitment is a limiting factor, juveniles need to be returned to the environment. In both cases experimental work has identified the importance of vertical relief, hydrodynamics, and a wider understanding of meta-populations in restoring reefs to levels that are self-sustaining and ecologically significant. Systematic approaches, based on the best science, are leading to successful restoration across the country, such as the restoration by the US Army Corps of Engineers of over 297ha of oyster reef since 2001 within the Chesapeake Bay, North America's largest estuary. Increasingly ambitious programs are being established; the recent Chesapeake Bay Executive Order (2009) resulted in the goal of restoring oyster populations in 20 of $35-40$ candidate tributaries of the Chesapeake by 2025 . This is an immense challenge given that oyster reefs were close to ecological extinction in this Bay just a few years ago.

Source: Philine zu Ermgassen and Mark Spalding, The Nature Conservancy and Cambridge University, Personal communication, 2010. Photo credits: Mark Spalding. benefits of successful oyster restoration on the Eastern Shore. Along the South Eastern United States, fin-fish and decapod fisheries benefits derived from restored oyster reefs have been estimated at $2.6 \mathrm{~kg} / 10 \mathrm{~m}^{2} /$ year, while in Louisiana and North Carolina restored intertidal reefs have locally reduced the rate of shoreline retreat. Work is in process to determine how such benefits may vary between locations.

The success of projects such as those on the Eastern Shore of Virginia provided a major impetus for encouraging the US government to provide USD 150 million in a 2009 national stimulus package for large-scale restoration projects, including several other oyster reef projects. More science is needed, notably to gain a better understanding of the final targets for restoration. How much restoration will be needed to achieve measurable and useful levels of water purification or increased fisheries production? Where and how should reefs be arrayed to maximize coastal protection benefits? Enough is already known, however, for the work to commence, and the research is running in parallel, enabling benefits to be derived even as understanding of the complex ecological story is refined.

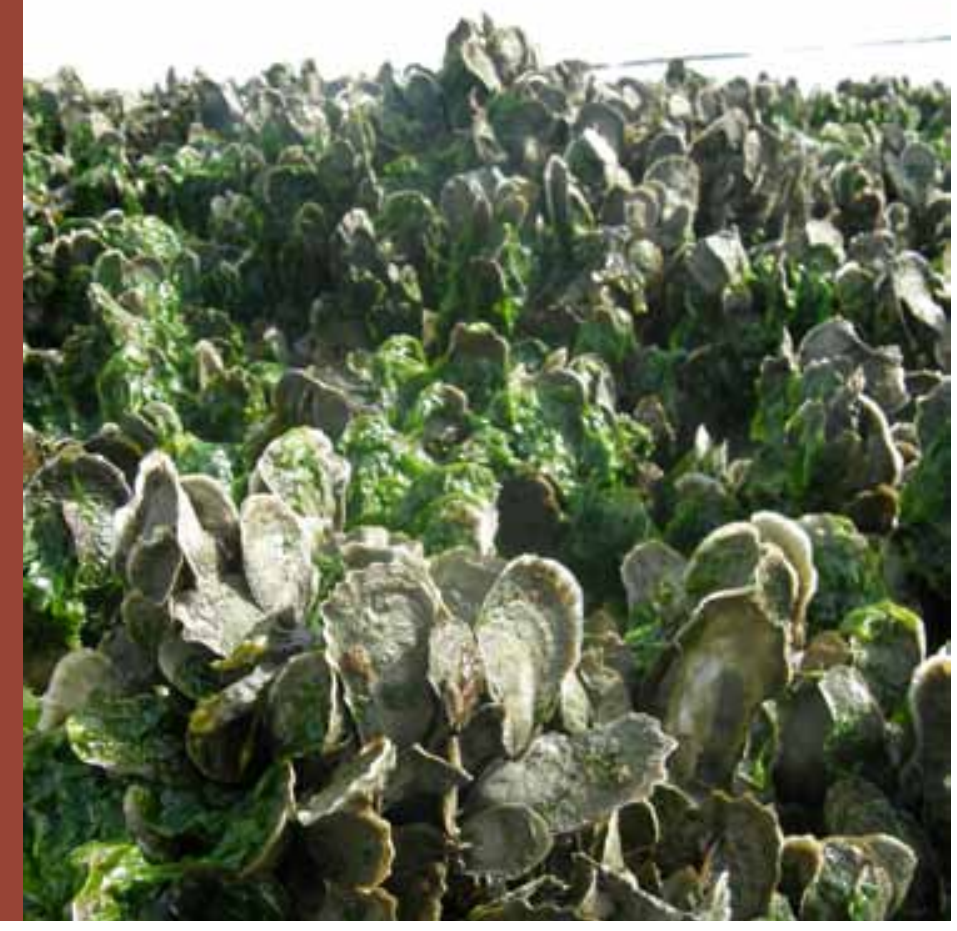




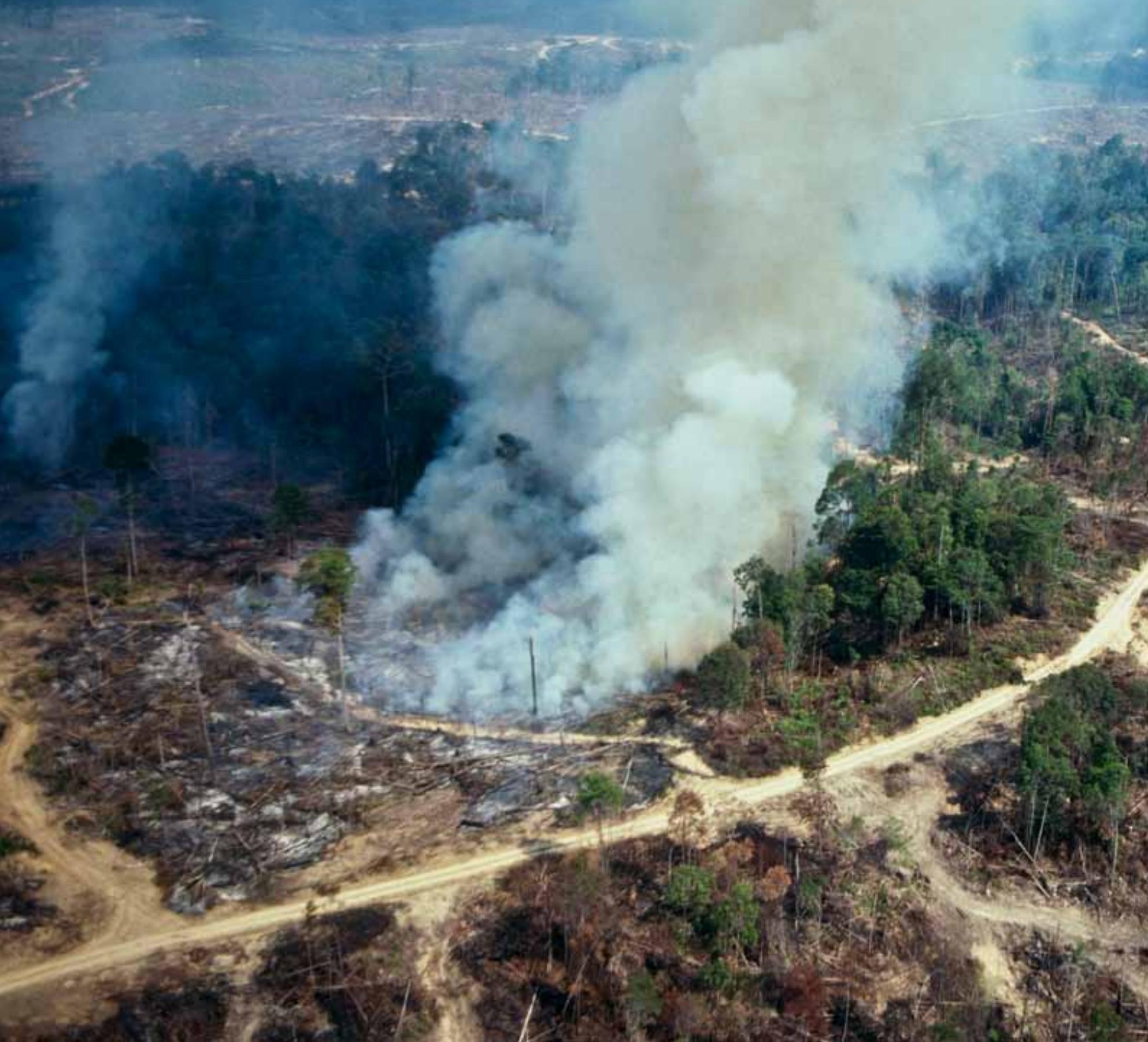




\section{ECOSYSTEM RESTORATION FOR CLIMATE CHANGE MITIGATION}

All living matter (biomass) - from grasses and trees to salt marshes and plankton stores carbon. Terrestrial biomass carbon stores are often referred to as "green carbon". Worldwide, terrestrial vegetation, soil and detritus currently store 226I Gigatonnes of carbon (GtC; IPCC, 2007) ${ }^{\mathrm{I}}$. Approximately half of terrestrial biomass carbon stocks are found in forest (IPCC, 2007). The oceans and coastal vegetation also store a large amount of carbon (often known as "blue carbon"), which is thought to be approximately $38334 \mathrm{GtC}$ (IPCC, 2007), though there is uncertainty about the precise quantity (Nellemann et al., 2009).

Much recent attention has been given to the potential of ecosystems, especially forests, to take up (sequester) additional carbon and hence mitigate climate change. Unfortunately, this process is disrupted when natural ecosystems are converted for agricultural use. This releases much of the carbon stored in plants and soil, and also alters the physical and biological effects of the landscape on the climate (Bala et al., 2007).

Some of these effects warm the climate, whilst others cool it. The high albedo (reflectivity) of grassland and deserts plays a role in atmospheric cooling (Hansen et al., I998; Thompson, I998). High rates of evapotranspiration (release of water into the atmosphere) from tropical forest reduce surface air temperature and increase rainfall (Bonan, 2008). The structure of vegetation also influences the regional climate: for example, a study in Australia found that land cover change (mainly defor-

I To illustrate how substantial these ecosystem stores of carbon are, the global annual emissions of carbon dioxide from human activity in 2004 totalled 38 Gigatonnes (IPCC 2007).2 Services include provisioning (e.g. fish and minerals), regulating (e.g. role in climate), supporting (e.g. role in water cycle) and cultural (e.g. tourism, recreation) estation) explained up to $50 \%$ of the observed warming and changes to rainfall patterns due to reduced surface roughness (Pitman et al., 2004).

The marine environment also has a key role in climate regulation. The oceans store and conduct heat, while ocean chemistry is important in regulating carbon uptake (IPCC, 2007; Reid et al., 2009).

Restoration of terrestrial and marine ecosystems therefore protects and enhances the climate regulating services of ecosystems as well as the carbon stocks that aid climate change mitigation.

Many ecosystems are currently carbon sinks (they store more carbon than they lose). The IPCC Fourth Assessment (AR4) Report suggests that the size of the terrestrial sink is approximately $0.5^{-\mathrm{I}} .5 \mathrm{GtC}$ per year while the marine sink is approximately I.8-2.6 GtC per year (IPCC, 2007). However, land use change and degradation damage the terrestrial sink as well as generating carbon emissions (Ong, I993; Anser et al., 2005; Eliasch, 2008; Lal, 2008). 


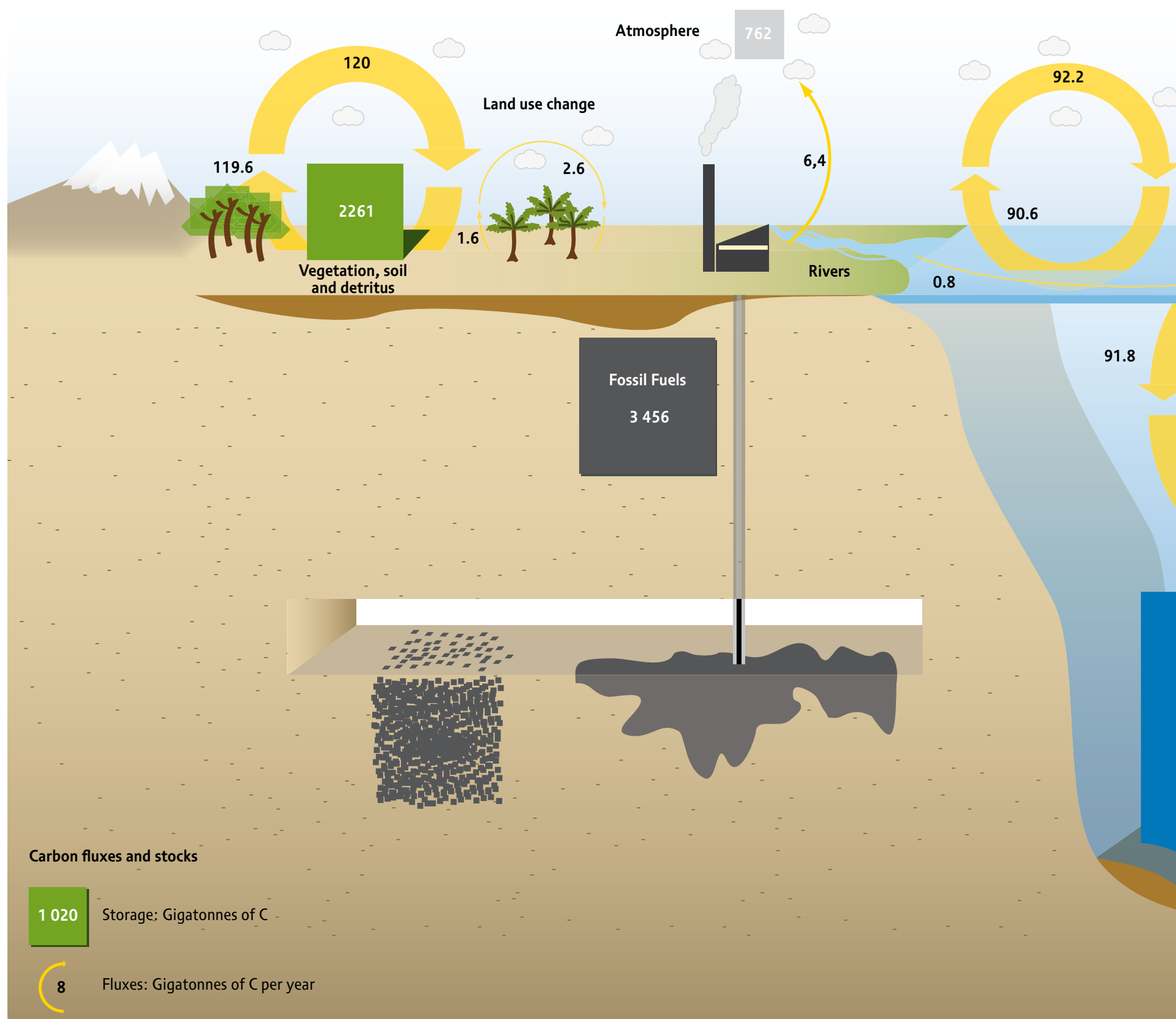




\section{Carbon cycle}

\section{Ocean surface}

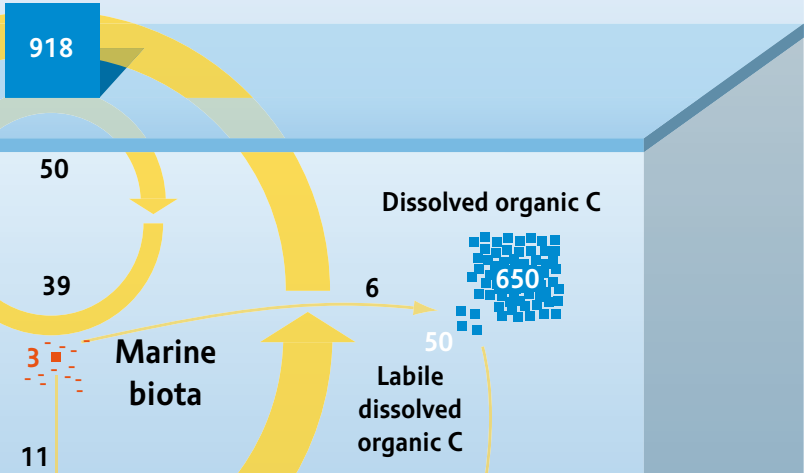

101

6

Intermediate and Deep ocean

38100

0.2

150

Sediments
Ecosystem restoration can therefore play a role in mitigating climate change, mainly through increasing carbon sequestration and storage. Forests, typically the most carbon-dense terrestrial ecosystems, often receive most attention in climate policy.

It is especially relevant that the negotiations on reducing emissions from deforestation and forest degradation (REDD) in developing countries under the UN Framework Convention on Climate Change (UNFCCC) have expanded to include other forest activities ("REDD+"). It is possible that new funds for carbon-focused restoration, afforestation or reforestation efforts could emerge (Miles, 20I0).

Forest restoration usually involves either reforestation or managing degraded forests with the aim of bringing them back towards a 'natural' state. Restoration can be achieved either through controlling pressures on forests, such as fires, invasive species or unsustainable harvest, or through techniques to speed forest recovery such as planting programmes or attracting seed dispersers.

Other reforestation or afforestation approaches, such as commercial tree plantations using non-native species or intensive management techniques, fall short of ecosystem restoration objectives but do also sequester carbon. These new forests are less likely to provide other ecosystem services or biodiversity benefits, and may be less resilient to the effects of climate change on their carbon stores.

Sometimes forest restoration or afforestation is undertaken with support from carbon finance in recognition of its role in climate change mitigation. For example, in the Scolel Te project in Mexico, farmers planted over 700 ha of trees on degraded land to sequester carbon, funded by the carbon offset market which generated USD I80 000 in 2002 (Tipper, n.d.). Carbon credit sales were also used to restore 36500 ha of Caribbean pine forest in Belize, creating a $0.013 \mathrm{GtC}$ benefit over 55 years, as well as protecting wildlife and enhancing soil quality (Walden, n.d.).

Carbon stored in soils forms a large part $(\sim 8 \mathrm{r} \%)$ of the total terrestrial store (IPCC, 200I, 2007), but has been degraded over wide areas. Depletion of soil organic carbon (SOC) may

Figure 11: The role of ecosystems in the global carbon cycle. 
have emitted $78 \mathrm{GtC}$ to the atmosphere between I850-I998 (Lal, 2004). Restoring degraded soils enhances soil carbon sequestration and promotes biomass growth (Lal, 2008). SOC content can recover over time with restoration of degraded soil through revegetation and good management practices (Lal, 2004; 2008). For example, dryland restoration could bring global carbon sequestration in arid ecosystems up to 0.8-I.9 GtC per year (Keller and Goldstein, I998; Lal, 2009).

Wetlands and peatlands are rich in carbon. Peatlands, although forming only $3 \%$ of the world's land surface, contain $30 \%$ of all global soil carbon (Parish et al., 2008). Large areas of wetland and peatland have been drained or disturbed, releasing $\mathrm{CO}_{2}$ into the atmosphere. Restoration could reverse this process and prove to be a low-cost greenhouse gas mitigation strategy (IPCC, 2007), though restoration of very degraded areas can be a slow process (Lal, 2008). A successful forest peatland restoration project in Indonesia restored approximately 60000 ha of peatland, reduc-

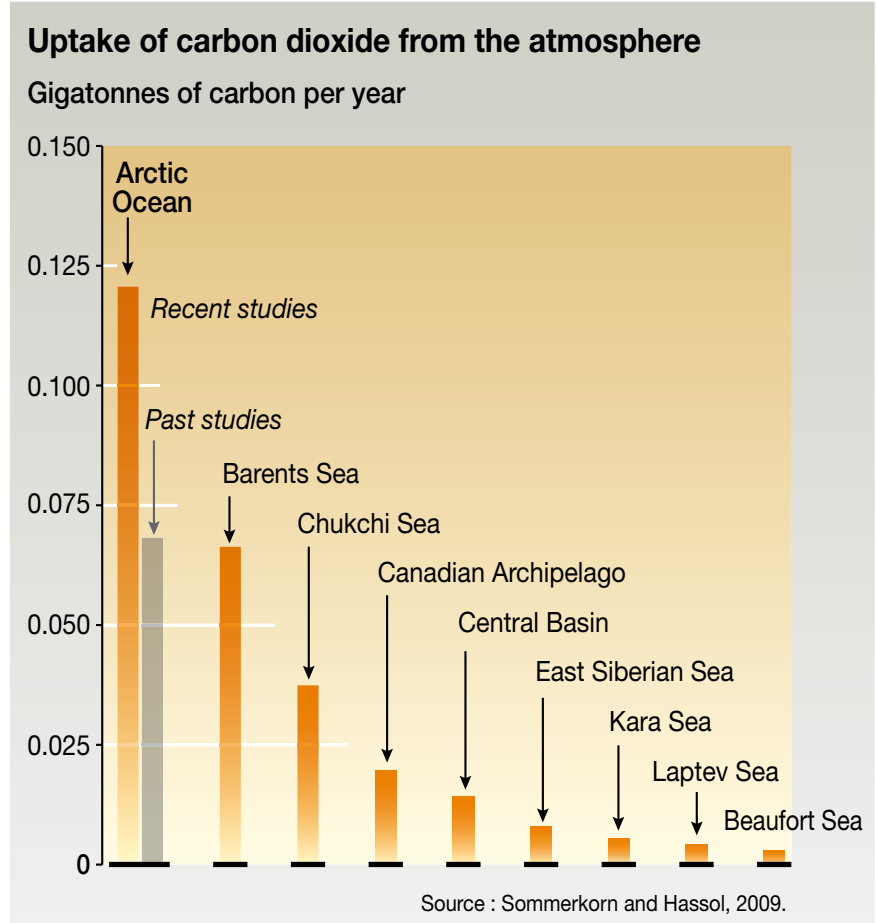

Figure 12: Blue carbon: Uptake of $\mathrm{CO}_{2}$ in different oceans worldwide (Sommerkorn and Hassol 2009). ing emissions from the degraded peat of about I.I5 GtC per year (Society for Ecological Restoration International, 2009), and enhancing sequestration. Restoration of wetlands can therefore increase carbon storage as well as maintaining other climate regulation services. At a global scale, $\mathrm{CO}_{2}$ emission from peatland drainage in Southeast Asia is contributing the equivalent of I.3\% to $3.1 \%$ of current global $\mathrm{CO}_{2}$ emissions from the combustion of fossil fuel (Hooijer et al., 20IO)

Restoring wetland, watershed and river ecosystems also indirectly contributes to climate change mitigation by protecting coastal vegetation and the ocean from excessive sediment and nutrient flows. Protecting, improving management and restoring coastal and marine carbon sinks (blue carbon) would prevent the release of up to $0.45 \mathrm{GtC}$ per year (Nellemann et al. 2009).

Vegetated coastal habitats, such as mangroves, salt marshes and sea grass meadows, sequester carbon in their biomass and

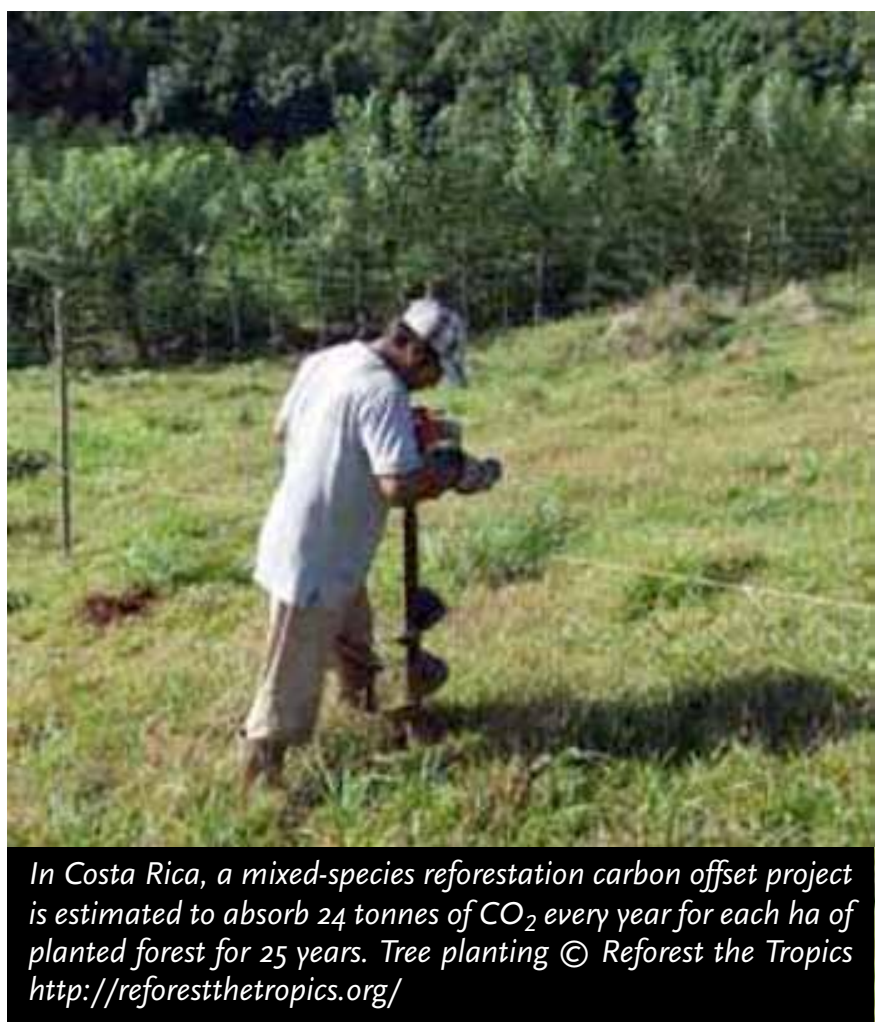


the sea floor (Nellemann et al., 2009). Coastal vegetation is estimated to take up an average of 0.II-0.I3 GtC per year (Cebrián and Duarte, I996; Duarte et al., 2005; Bouillon et al., 2008).

Mangroves are large carbon sinks ( ०.०I8 GtC per year globally) and highly productive in terms of primary productivity and wildlife (Bouillon et al., 2008; Laffoley and Grimsditch, 2009). Coastal habitats can also be crucial for climate change adap- tation, such as coastal defence, and provide many resources important to livelihoods. In Vietnam, a mangrove restoration programme found that the economic value of such benefits outweighed the costs (Table I; Tri et al., I998).

Salt marshes sequester $\sim 0.06 \mathrm{GtC}$ per year globally and I.5I $\mathrm{xIO}^{-3} \mathrm{GtC} / \mathrm{ha} /$ year (Duarte et al., 2005), a great proportion of which is sequestered in the soil (Chmura et al., 2003); as such

\section{CASE STUDY \#22}

\section{Peatland restoration in Central Kalimantan for climate, biodiversity and livelihoods}

The peatswamp forests of Central Kalimantan have heavily been degraded by logging and drainage for conversion into agricultural lands and oil palm and pulp plantations (UNEP, 2007). This situation leads to incredible carbon dioxide emissions and annually long lasting fires, causing smoke and health problems. The peatlands in Central Kalimantan constitute some of the poorest areas in Indonesia, largely because of unsuccessful developments, large scale environmental destruction and peat fire disasters. The poverty rates in the area are 2 to 4 times higher than in other areas of Indonesia.

Peatland degradation will continue unless action is taken. So far 12 million hectares of peatland are currently deforested and mostly drained in Southeast Asia, including over 1.5 million hectares in Central Kalimantan, with severe consequences for global climate, biodiversity and local communities. Peatland conservation and restoration is therefore extremely urgent. A consortium made up of the Borneo Orang Utan Survival Foundation (BOSF), CARE, the World Wide Fund for Nature (WWF), Wetlands International and the University of Palangka Raya therefore worked closely with the provincial and local authorities to help.

The priority of the project was peatland rehabilitation, which involved the restoration of the hydrology of the drained peatswamp forests, reforestation efforts and fire control. The project resulted in the establishment of 18 dams in large drainage canals and over 150 blocks in small drainage channels, contributing to the restoration of thehydrology of 10,000 ha in the Sebangau area and over 50,000 hectares of drained and degraded peatlands in the Ex-Mega Rice area. In total we estimate a re- duced emission of at least 4 million tonnes of carbon dioxide per year by reducing decomposition only. These emissions would, without these restoration activities, have continued for some decades until they would gradually phase out as a result of the overall decimation of the peat store. Additionally reduced emissions resulting from fires were achieved; around 250,000 hectares of peatland now has improved security from fires and fire-fighting capacity has been improved in 25 villages. A total of 1500 ha of the hydrologically restored area was replanted with indigenous tree species.

Another focus of the project was to conserve any remaining peat swamp forests. This work was complemented by a range of efforts to reduce poverty, including improving local health facilities, the development of an alternative livelihood strategies and investments in socioeconomic development through the development of sustainable fisheries, agriculture and forestry. On a global level the project has strongly increased awareness about the peatland problems in Indonesia. The proposed REDD policy under the UN climate conference (deforestation in developing countries; status after Copenhagen 2009) now opens the road to also address peatland loss; with funds provided by developed countries to reduce deforestation and forest degradation in developing countries.

With its innovative approaches, CKPP can be seen as an example for provincial and country authorities, institutions and NGOs of how to integrate the principles of sustainable development into policies and programmes for large scale restoration of logged and drained peatlands and for the protection of intact area. 
they provide a larger carbon sink than mangroves which sequester I.39 xio-3 GtC/ha/year (Duarte et al., 2005). However, they are also considerable sources of methane, but over a long time period $(\sim 500$ years) remain a greenhouse gas sink (Whiting and Chanton, 200I).

Seagrass meadows are particularly good carbon sinks, as the leaves last much longer than other marine biomass such as phytoplankton (Duarte et al., 2005) and because they deposit carbon into the ocean soil, resulting in long-term sequestration (Romero et al., 1994).

The greatest oceanic absorption of $\mathrm{CO}_{2}$ occurs in cold waters or in areas with high organic matter (Barry and Chorley, I998). The carbon cycle in the oceans is influenced by physical and biological processes (Reid, 2009). Global ocean services ${ }^{2}$ may be worth about USD 23 trillion a year, only slightly less than the world's GNP (GESAMP, 200I) and therefore maintaining healthy ecosystems is economically important. There is also evidence that healthy functioning marine ecosystems are necessary to enable the continued marine sequestration of carbon from the atmosphere (e.g. EC 2009; Herr and Galland 2009; Laffoley and Grimsditch 2009).

Climate change is in itself a driver of ecosystem degradation and affects carbon sequestration and storage. Climate change impacts on ecosystems and on mitigation efforts should be taken into account during restoration activities to ensure long-

2 Services include provisioning (e.g. fish and minerals), regulating (e.g. role in climate), supporting (e.g. role in water cycle) and cultural (e.g. tourism, recreation)

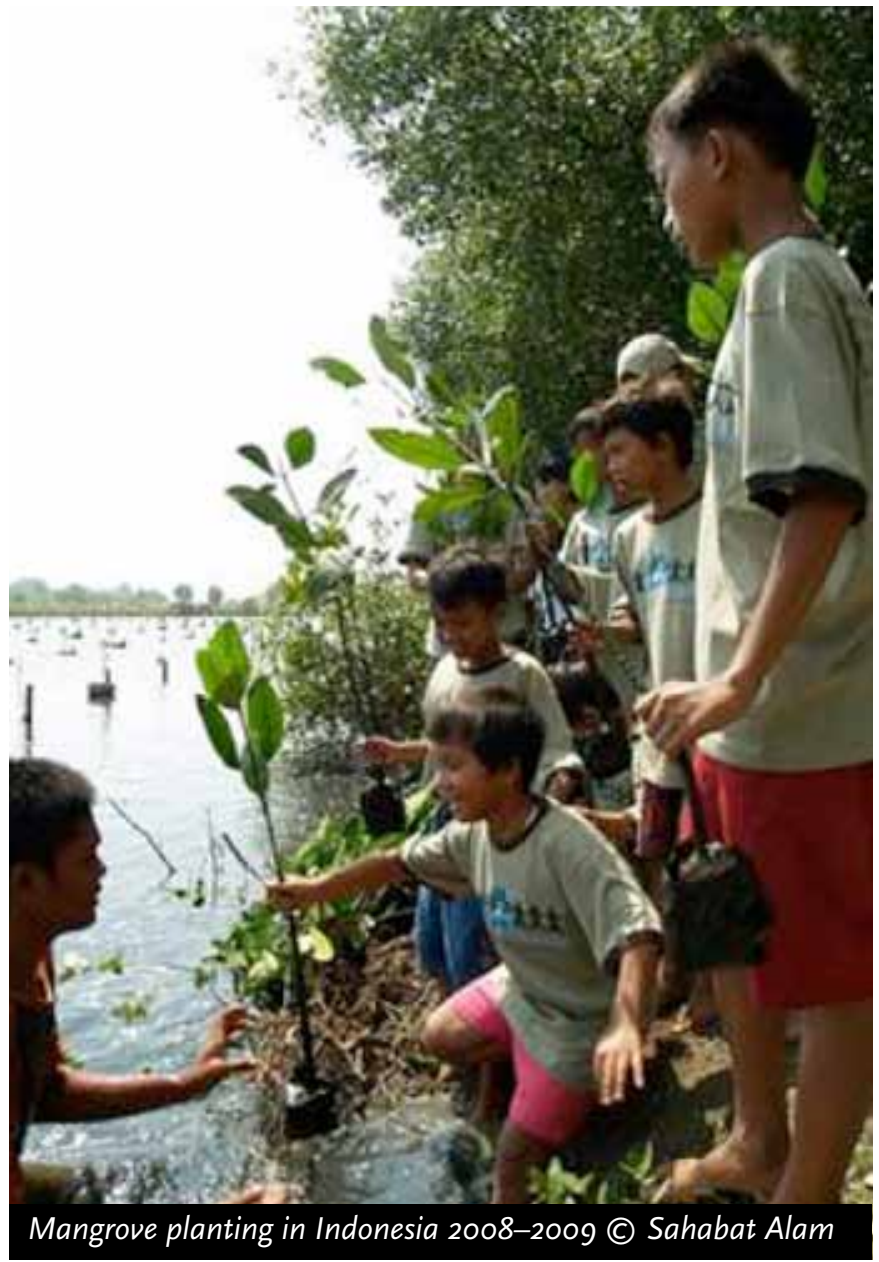

Table 1: Costs and benefits of direct and indirect use values of mangrove restoration (adapted from Tri et al. 1998)

\begin{tabular}{l|l|l|l}
\hline Discount rate & $\begin{array}{l}\text { Benefits } \\
\text { (direct - marketable products; indirect - } \\
\text { avoided maintenance cost of sea dyke system) }\end{array}$ & $\begin{array}{l}\text { Costs } \\
\text { (of establishment and extraction) }\end{array}$ & Overall benefit-cost ratio \\
\cline { 2 - 4 } & \multicolumn{2}{|c|}{ Present value, million Vietnam Dong/ha } \\
\hline 3 & 19.66 & 3.45 & 5.69 \\
6 & 13.12 & 2.51 & 5.22 \\
10 & 8.47 & 1.82 & 4.65 \\
\hline
\end{tabular}




\section{How to mitigate climate change: The role of natural ecosystems}

'Brown carbon': industrial emissions of greenhouse gases that affect the climate.

'Green carbon': carbon stored in terrestrial ecosystems e.g. plant biomass, soils, wetlands and pasture and increasingly recognised as a key item for negotiation in the UNFCCC (in relation to forest carbon and mechanisms such as REDD, REDD-Plus, or LULUCF).

'Blue carbon': carbon bound in the world's oceans. An estimated $55 \%$ of all carbon in living organisms is stored in mangroves, marshes, sea grasses, coral reefs and macro-algae.

'Black carbon': formed through incomplete combustion of fuels and may be significantly reduced if clean burning technologies are employed.

Past mitigation efforts concentrated on brown carbon, sometimes leading to land conversion for biofuel production which inadvertently increased emissions from green carbon. The proposed REDD (Reducing Emissions from Deforestation and Forest Degradation) instrument is based on payment for carbon storage ecosystem services and could lead to an estimated halving of deforestation rates by 2030 , cutting emis-

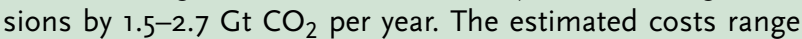
from USD 17.2 billion to USD 33 billion/year whilst the estimated long-term net benefit of this action in terms of reduced climate change is estimated at USD 3.7 trillion in present value terms (Eliasch 2008). Delaying action on REDD would reduce its benefits dramatically: waiting 10 more years could reduce the net benefit of halving deforestation by USD 500 billion (Eliasch, 2008; McKinsey 2008; TEEB, 2009).

term resilience (Harris, 2006; Erwin, 2009). It is also crucial to ensure that restoration objectives are consistent with local needs and aspirations, to ensure long-term success. In this way, ecosystem restoration can provide an effective climate change mitigation strategy.

\section{RESTORATION OF SEAGRASSES AND MANGROVES}

There is sufficient evidence to support that reversing the global decline of vegetated coastal habitats and recovering the lost area of blue forests would provide a very large improvement in the ecological status of the global coastal environment. This could result in the recovery of important services, such as their capacity to oxygenate coastal waters, serve as nurseries helping restore world fish stocks or the shelter the shoreline from storms and tsunamis (Hemminga and Duarte 2000; Danielsen et al., 2005).

For instance, the ongoing national wetland conservation action plan in China has been estimated to involve a potential for an increased carbon sequestration by $6.57 \mathrm{Gg} \mathrm{C}$ year-1 (Xiaonana et al., 2008). Andrews et al. (2008) calculated that the net effect of returning of returning some $26 \mathrm{~km}^{2}$ of reclaimed land in the UK to intertidal environments could result in the burial of about 800 ton $\mathrm{C}$ year-1.

A first involves the regulation of activities responsible for their global loss, including coastal reclamation, deforestation of mangrove forests, excess fertilizer application on land crops and inputs of urban effluents of organic matter, siltation derived from deforestation on land, unsustainable fishing and fixing of coastlines through coastal development (e.g. Borum et al., 2004; Hamilton and Snedaker i984; Melana et al., 2000; Duarte, 2002; 2009).

A second step should involve efforts for the large-scale restoration of the lost area, which is likely of the same order (if not larger) than the area currently still covered by these aquatic habitats (Duarte 2009; Waycott et al., 2009). For instance, some countries in SE Asia have lost almost 90\% of their mangroves over the last 60 years (Valiela et al., 200I). Large-scale restoration projects have been successfully conducted for mangroves. The single largest effort probably being the afforestation of the Mekong Delta forest in Vietnam, completely destroyed by the use of Agent Orange in the I970's and replanted by the Vietnamese people (Arnaud-Haond et al., in press). Saltmarsh restoration is also possible and has been applied largely in Europe and the USA (e.g. Boorman and Hazelden I995). Restoring lost seagrass meadows is more complex, as the labor required to insert transplants under the water increases cost (Duarte et al., 2005b), so has to be supported in parallel with actions to remove the pressures that caused the loss in the first place. While green forest can only grow upwards, seagrasses can spread horizontally at exponential rates.

Most efforts to restore blue forests have been driven by the need to restore coastal protection by vegetated habitats and their value as habitats for key species (Boorman and Hazelden, i995; Fonseca et al., 2000; Danielsen et al., 2005). 
CASE STUDY \#23

\section{Mekong Delta mangrove forest restoration}

Large-scale restoration of mangrove forests are feasible and affordable. The largest mangrove restoration was that of the

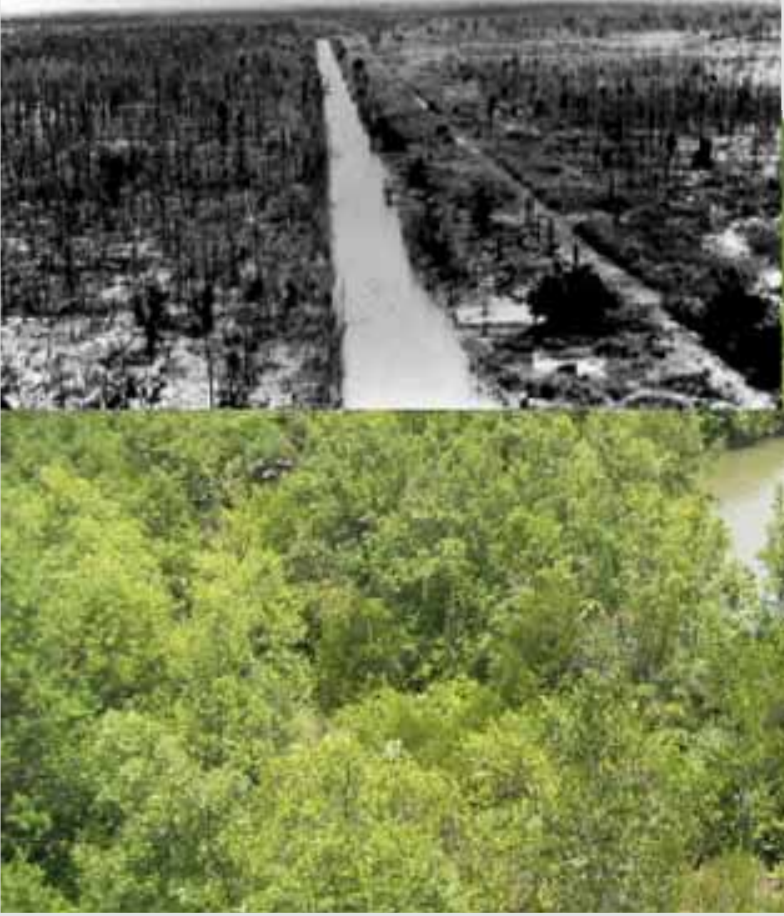

mangrove forest in the Mekong Delta completely destroyed by the US Air Forces in the 1970's (above) and subsequently restored by the Vietnamese government.

Black and white insert: "Results of Defoliation Operation", illustration from 'Vietnam Studies: Tactial and Material Innovations', by Lieutenant General John H. Hay, Jr.; www.army.mil/cmh-pg/books/Vietnam/tactical. Colour image: Professor Nguyen Homg, Universidad de Hanoi, Vietnam.
The costs to successfully restore both the vegetative cover and ecological functions of a mangrove forest have been reported to range from USD 225/ha to USD 216,000/ha (Lewis, 200I). Mangrove restoration projects have been classified into three categories (Lewis, 200I; 2005): (I) planting alone, (2) hydrologic restoration, with and without planting, and (3) excavation or fill, with and without planting. The first type, planting only, although inexpensive (e.g.: USD Ioo-200/ha) usually does not succeed due to a failure to appreciate the physiological tolerances of mangroves to tidal inundation. The second type, hydrologic restoration, can be done for similar costs, and with proper planning has a high success rate. Successful restoration of abandoned shrimp aquaculture ponds is an example of this method. Planting should only be done if natural recolonization fails, and can double the cost of a project. Scientific data indicates that using this method, ecological functions are quickly restored, with fish populations typically reaching reference site diversity and densities within 5 years. The third type, excavation and fill, is the most expensive due to the high costs of large scale earthmoving. 


\section{The West African Mangrove Initiative (WAMI)}

The West African seaboard from Mauritania to Sierra Leone including Senegal, the Gambia, Guinea Bissau and Guinea, is rich in mangrove formation. The riparian populations of this area draw substantial revenues from the exploitation of wood, fishing, rice farming, the extraction of salt and other activities, notably the collection of honey and medicinal plants. Even though these activities are important for livelihoods, they also have a negative impact on the mangroves; an impact which is increasing today in parallel with the demographic growth on the coast and climate change through changes in rainfall and duration of rainy season. As for the impact of economic activities, these are more and more acute and affect all the countries. The most significant anthropogenic threats to mangrove areas are:

Clearing for Agriculture (rice) and aquaculture (shrimp), fish smoking, Saliculture (Guinea, Sierra Leone, Guinea Bissau), Shellfish calcination (Gambia, Senegal), Urban domestic needs (Freetown, Conakry, Kamsar, Bissau, Banjul.), Rural domestic needs.

The situation is critical and requires reversing the trend in order to maintain the ecological function of the area. An initiative was developed to rehabilitate the mangroves, help harmonize national policies for its sustainable management and improve the well being of the communities who depend upon the mangroves. A joint initiative through IUCN Senegal and Wetlands International Africa form the West African Mangrove Initiative (WAMI), working hand in hand with the Swiss MAVA Foundation and National forestry institutions in Mauritania, Senegal, Gambia, Guinea Bissau, Guinea and Sierra Leone.

WAMI activities include the rehabilitation of areas of deteriorated mangrove, develop demonstration projects, build national mangrove conservation policies, help draft the Charter and Action Plan, and seek funding for the latter. Replanting operations drew on the lessons learnt in the 2008 campaign. Improvements were made through the capacity building of the players, site selection and meeting the planting schedule. Since the project started, the total re-planted mangrove area in Senegal, Gambia, Guinea, Guinea Bissau and Sierra Leone covers 20 ha. The vulgarisation of beekeeping in Gambia continued and the first harvests of hon-

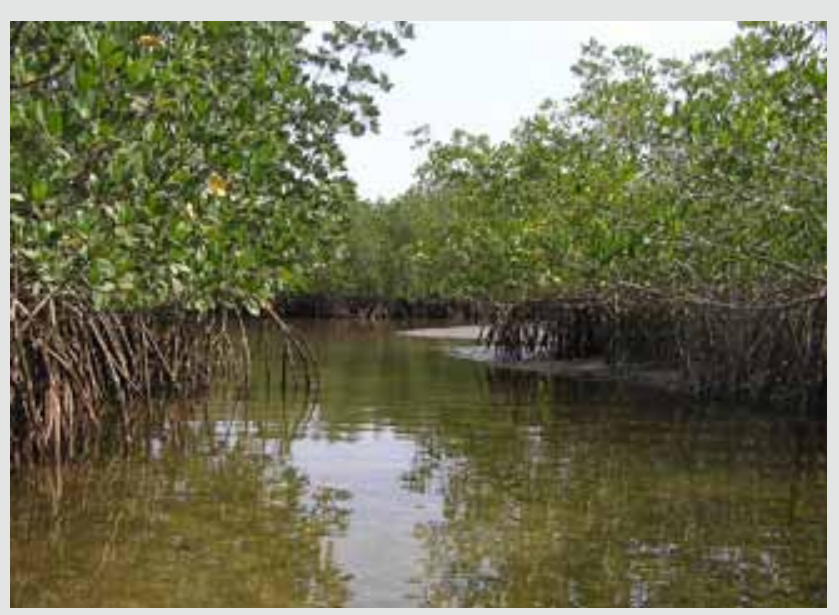

ey meant that community training on the post-harvest handling of honey was able to begin. As for the construction of improved ovens for the smoking of fish in Guinea Bissau, work is in the final phase in three of the four scheduled sites.

In terms of the mangrove management policy, stress was placed on consolidating the Preliminary draft of the regional charter and action plan. The document was submitted for review to several specialists and their remarks and suggestions were incorporated into the final version. It has now been submitted to the different countries for their opinion.

In addition, the project developed partnerships with various conservation players, in particular: the NGO Océanium in its reforestation programme in Senegal funded by Danone; the Adaptation to Climate and Coastal Change (ACCC) project for the replanting of the mangrove in the Palmarin area, funded by the UNDP and UNESCO, and ENSA (Ecole Nationale Supérieure d'Agriculture) in Thiès for evaluating growth conditions and the carbon sequestration capacity of the replanted sites around the village of Dassalamé Sérer in the Saloum Delta.

Source: Wetlands International, Personal communication, 2010 
$2 \sin y$ as

nin:

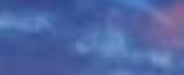

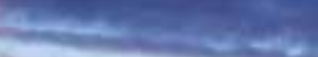

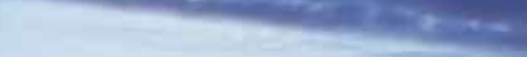

20.7.

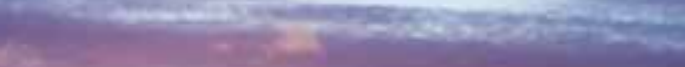

\section{3 응}

6.

\section{- Se}

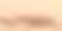

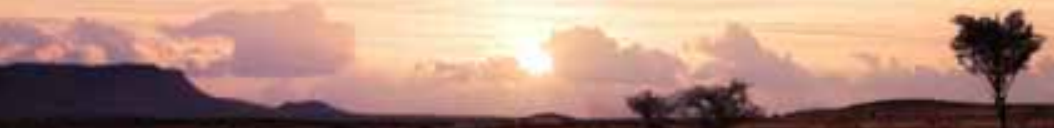

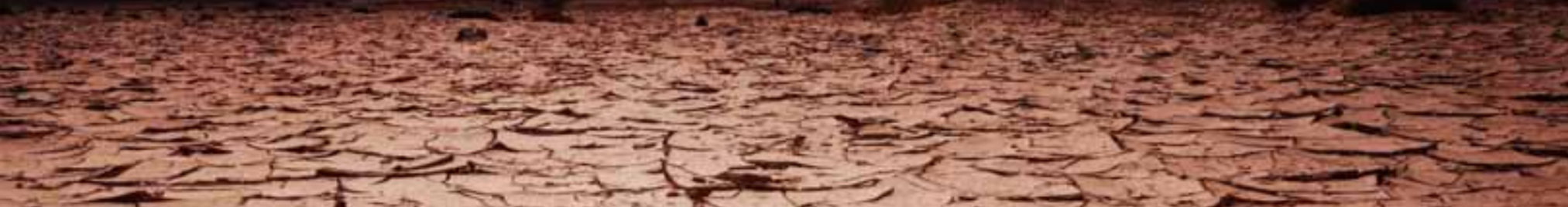

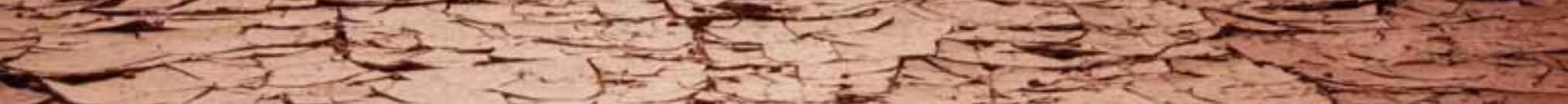

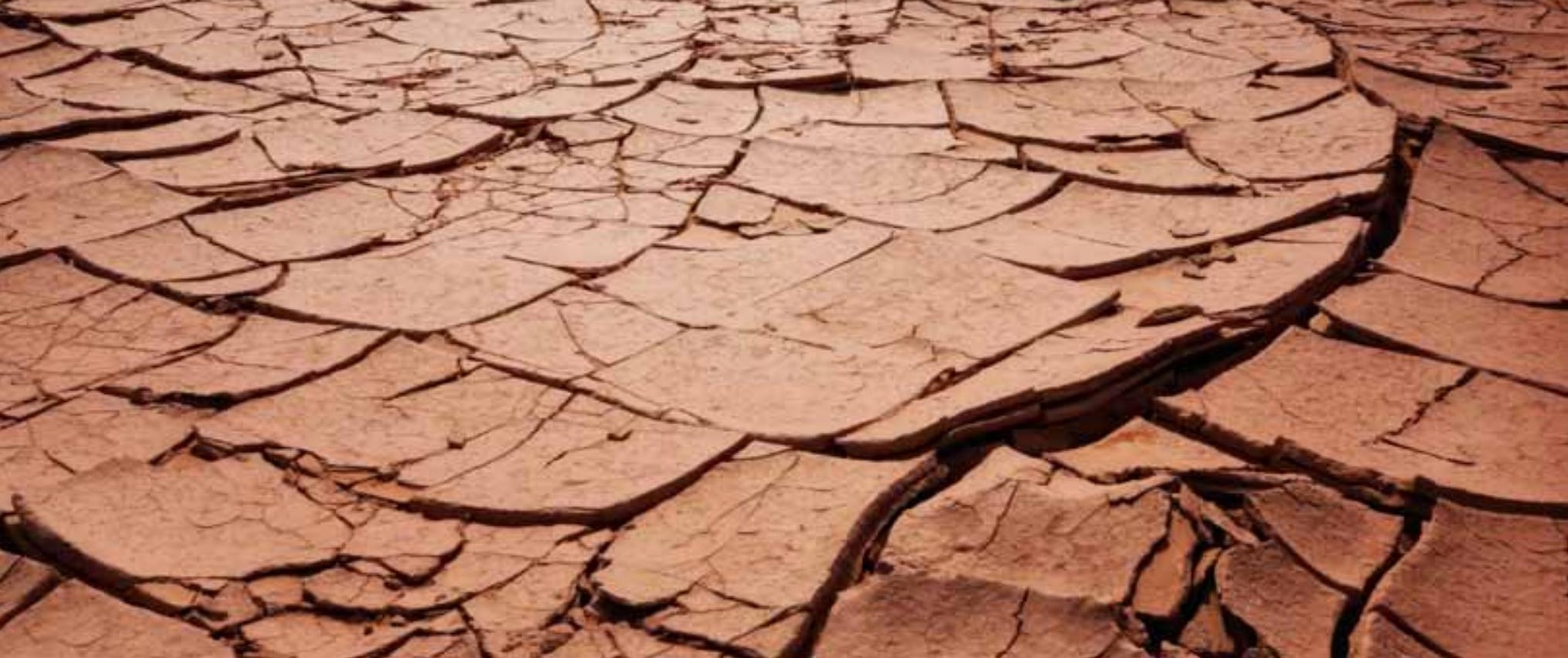




\section{ECOSYSTEM RESTORATION FOR DISASTER PREVENTION AND MITIGATION}

Ecosystems play a crucial role in reducing, mitigating and avoiding major hazards and disasters worldwide - while their destruction and degradation may both exacerbate or even cause catastrophes: Every year 270 million people in the world, $85 \%$ of them in Aisa are exposed to natural disasters and some 124 oo people are directly or indirectly killed.

Natural ecosystems that help prevent disasters include natural vegetation and forests on slopes and hill sides and catchment forests hindering erosion and slowing passage of water from rainfall (Zhao et al., 2009), wetlands providing buffers for floods (Costanza et al., 2008), riparian zones influencing water chemistry (Dosskey et al., 20I0); mangroves and coral reefs for waves, tsunamis and storms (Badola and Hussain, 2005; UNEP, 2007; 2009), vegetation in drylands hindering erosion (UNEP, 2006; Lal, 2009), forests and mangroves in estuaries buffering flood effects (Tallis et al., 2008) not to mention the function of ecosystems in buffering further land degradation and providing live-able conditions for people and animals worldwide by protecting the local climate.

The value of coastal wetlands for hurricane protection has been estimated at 250-51,000 USD/ha/year, with an average of $8240 \mathrm{USD} / \mathrm{ha} /$ year, with coastal wetlands in the US currently providing storm protection services valued at 23.32 billion USD annually (Costanza et al., 2008). Mangroves have been estimated to reduce damage of storm floods to impoverished by an average of 33.3I USD/household compared to unprotected villages with damages over I53.74 USD/household (Badola and Hussain, 2005).

Potential damage from storms, coastal and inland flooding and landslides can be considerably reduced by a combination of careful land use planning and maintaining/restoring ecosys- tems to enhance buffering capacity. Planting and protecting nearly I2,000 hectares of mangroves cost USD I.I million but saved annual expenditures on dyke maintenance of USD 7.3 million.(Tallis et al., 2008; TEEB, 2009).

Table 2: Number of people affected by natural disasters in Asia (row 1-4) and the world (row 5) 1998-2008

\begin{tabular}{l|l|l}
\hline Type of disaster & No. affected/year & No. killed/year \\
\hline Flash floods & & 5000 \\
Seasonal floods & 100000000 & 4000 \\
Droughts & 80000000 & 30000 \\
All natural hazards & 230000000 & 100000 \\
WORLD & ca. 270000000 & ca. 124000 \\
\hline
\end{tabular}

Source: FAO 2001, Benniston 2003, jianchu et al. 2007, USAID 2007, UNU-IAS 2008, Eriksson et al. 2009 a, b. ICIMOD 2009, Pacific Disaster Center 2009, World Disaster Report 2009.

Table 3: Relative vulnerability to floods across continents (19982008) (World Disaster Report 2009)

\begin{tabular}{l|l|l|l|l}
\hline & Africa & Americas & Asia & Europe \\
\hline Affected & 22173000 & 14315000 & 801634000 & 1273000 \\
Killed & 7623 & 38281 & 38735 & 1245 \\
\hline
\end{tabular}




\section{Restoration of mangroves in Andra Pradesh, India}

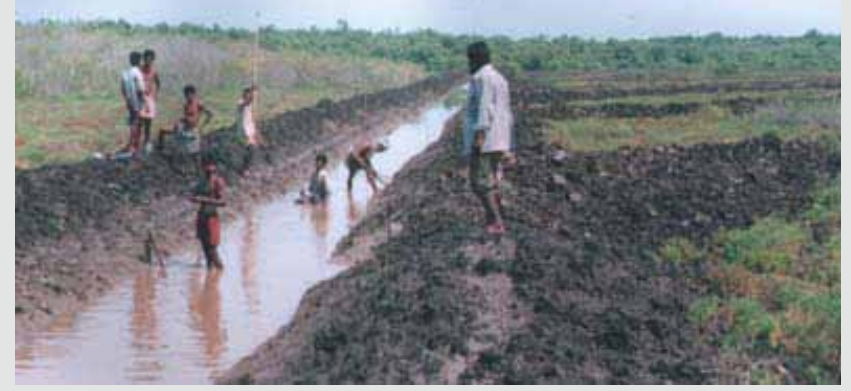

This project was launched in Andhra Pradesh with the aim of inducing concerted action towards conservation and sustainable management of the mangrove wetlands on the east coast of India. The restoration, with a budget of 3.010 million USD successfully restored mangroves on over 520 ha from 1997-2004. Until 1972, mangroves were clear felled in many parts of the region, and these areas have not been able to regenerate due to topographic changes. Not only that, the Krishna river is one of the heavily utilized rivers in peninsular India and is exploited for a variety of purposes. As a result, there has been a reduction in fresh water flow over a period of time, which has had a telling impact on the growth and regeneration of mangroves.

Another important contributor to ecosystem degradation is the rapid siltation and pollution of Kakinada Bay, as evidenced by a recent hydrographic study. With increased developmental activities and the establishment of fertilizer units, some effluents are being discharged into the bay. This has resulted in high amounts of ammonium and nitrate in bay waters, which may be contributing to degradation. Furthermore, the present depth of the bay is very low, and there is hardly any lateral mixing of waters. Therefore, there is a lot of stagnation in the bay which may also be affecting the mangroves. A variety of anthropogenic activities has compounded these environmental conditions and has helped hasten the decline of the mangroves. Coastal villagers utilize mangroves for their basic needs such as firewood, fodder, fencing, house construction, thatching and fishing poles. Mangrove forests are also being converted into aquaculture ponds, salt pans and paddy fields with increasing frequency.

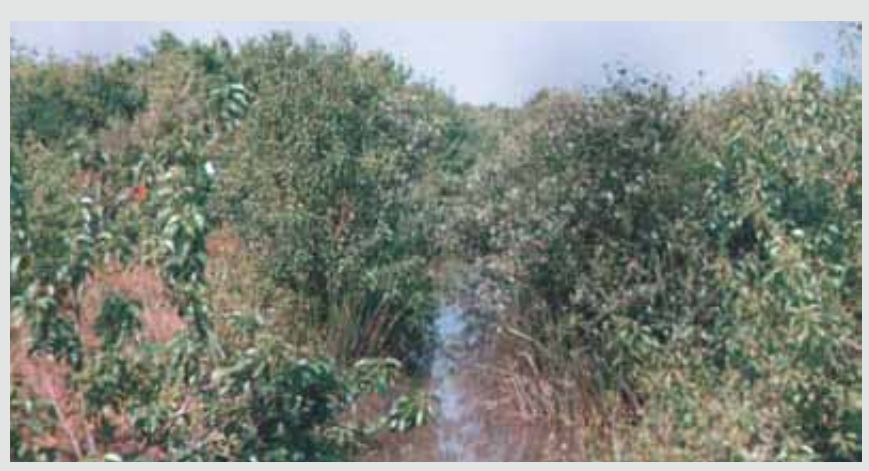

The project employed canal techniques, instead of simple plantation of seedlings, and a fish bone pattern of canals was utilized. This fishbone design was shown to be a more efficient method of facilitating tidal flushing than the rectangular pattern used by the Forest Department. Thus, this technique has now been adapted and recommended by the Government of India for other restoration projects.

The bio-diversity of the area has been positively impacted by the restoration. The crab population in the restored areas has increased due to the increased water regime. As biodiversity has improved and the denuded patches have been covered with mangroves, populations of larger animals like otters have also increased substantially. In addition to this, the bird population has shown an increase since the project began.

With the improvements made in hydrology, further degradation of mangroves has stopped. Mangroves are now naturally regenerating, and the canopy cover has become denser, as evidenced by remote sensing images taken recently. The newly established water regime has increased the population of edible crabs in the restored areas, and this is a benefit for the livelihood of local communities. There has also been good growth of fodder grass which has helped the local community in feeding their livestock. The newly established water regime has increased the population of edible crabs in the restored areas, and this is a benefit for the livelihood of local communities. There has also been good growth of fodder grass which has helped the local community in feeding their livestock.

Source: SER, 2010 www.globalrestorationnetwork.org/database/case-study/?id=141 


\section{Average cost of natural disasters by region, 1990-2008}

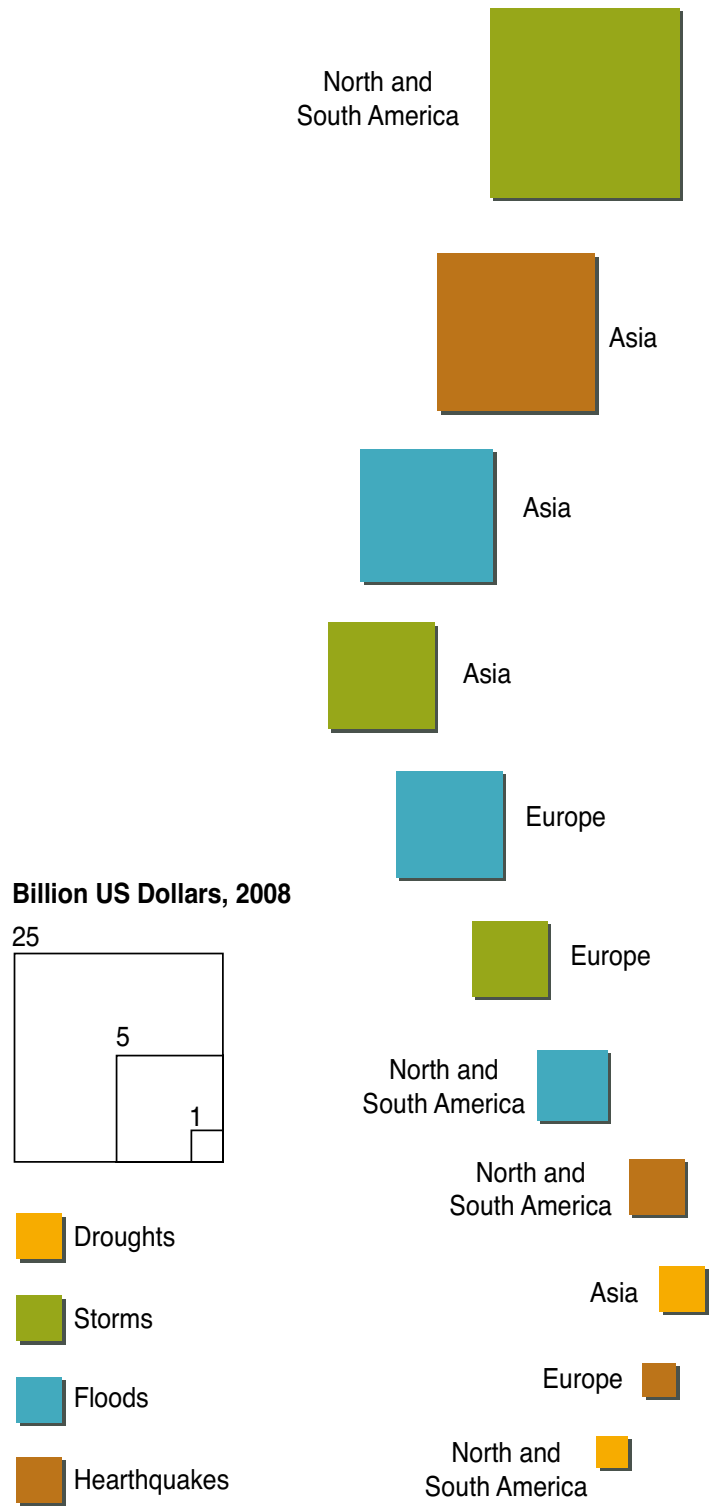

Source: EM-DAT, The International Disasters Database, CRED, 2009.

Figure 13: Average cost of natural disasters per region 1990-2008

\section{CASE STUDY \#26}

\section{Butterfiy Valley at Coega, Port Elizabeth, South Africa}

Top: Erosion gullies in a hot, steep, calcrete slope (part of the ancient Coega River Estuary) scarred by old livestock tracks, deeply scoured by wind and rain, lead down to a freshwater earth dam. Bottom: 2 years after slope rehabilitation using endemic plants salvaged from adjacent Deepwater Port development. Rainwater is channelled into the hillside where backfilled terraces now support buck, small mammals, reptiles, birds and insects. Trees and shrubs are coming back via these animals.

Project and photos credit: Linda Redfern Landscape \& Environmental Services.
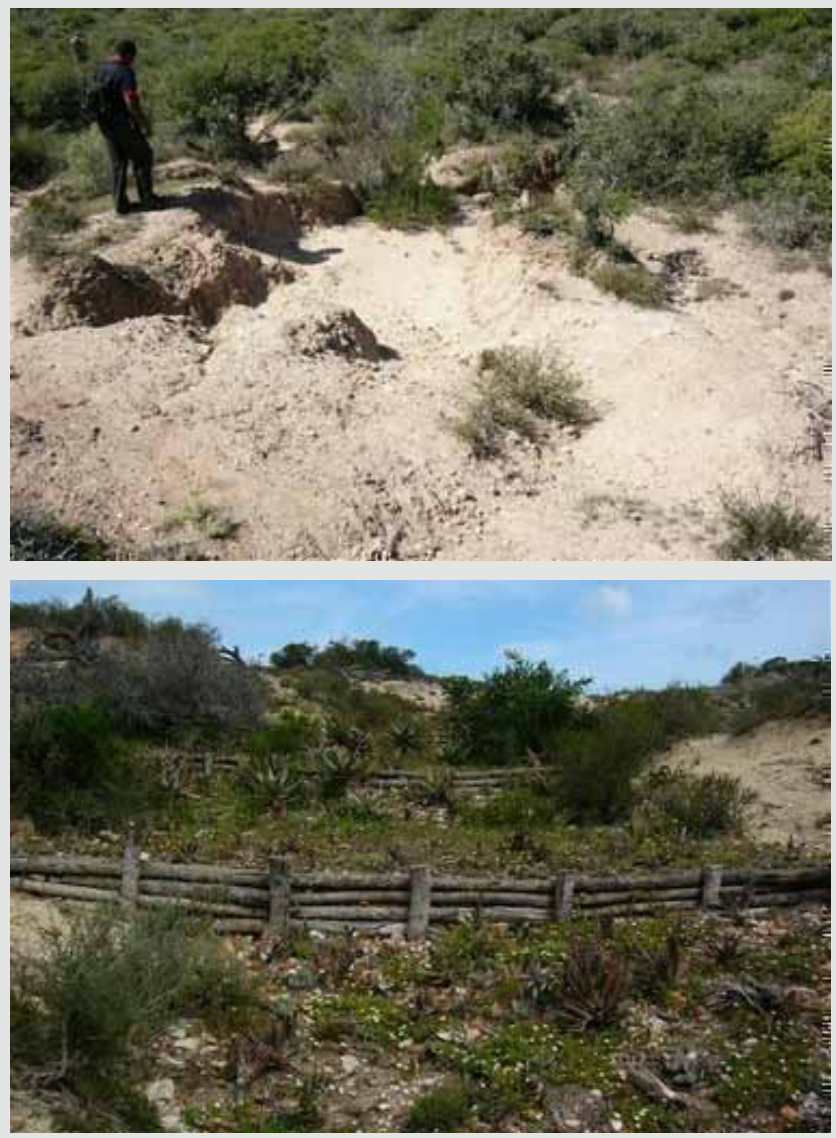


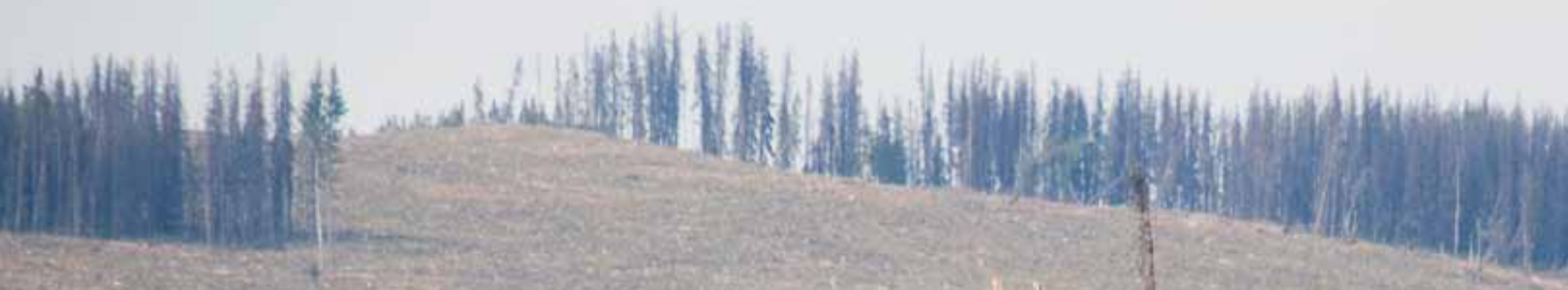

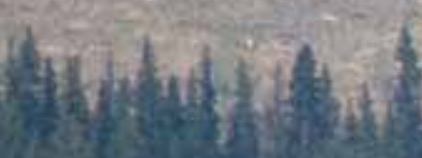

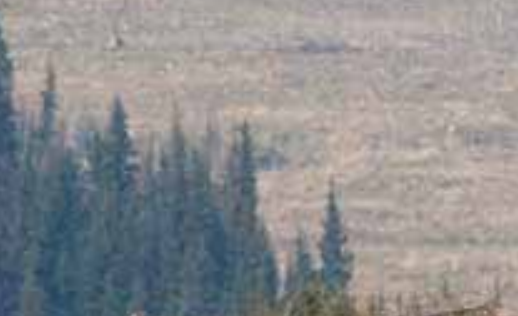

(1)

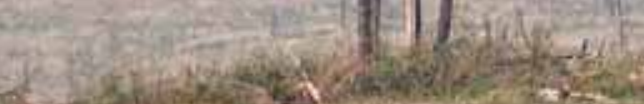

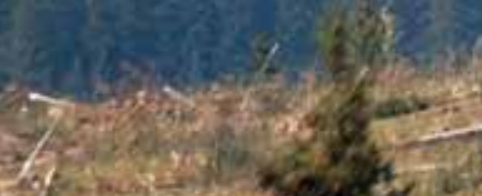

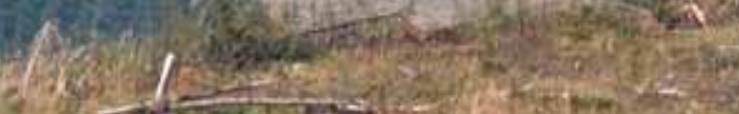

7. $=3$

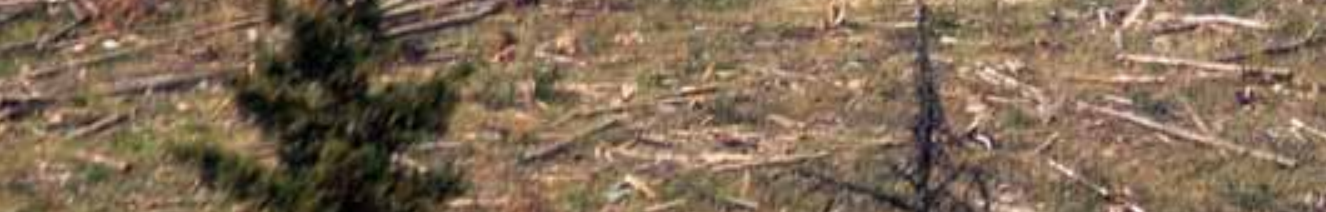

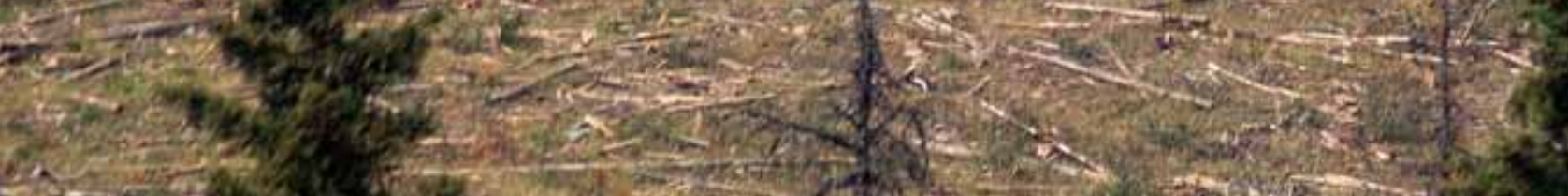

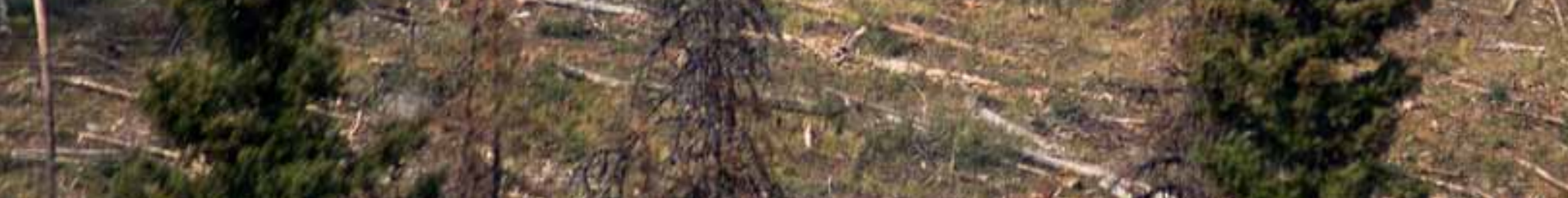

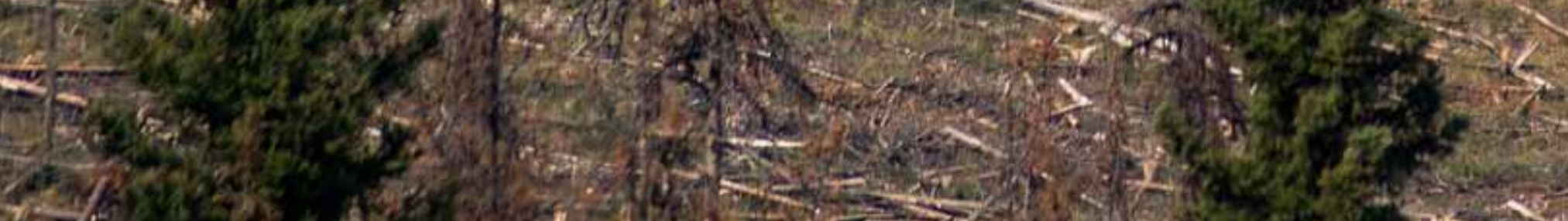

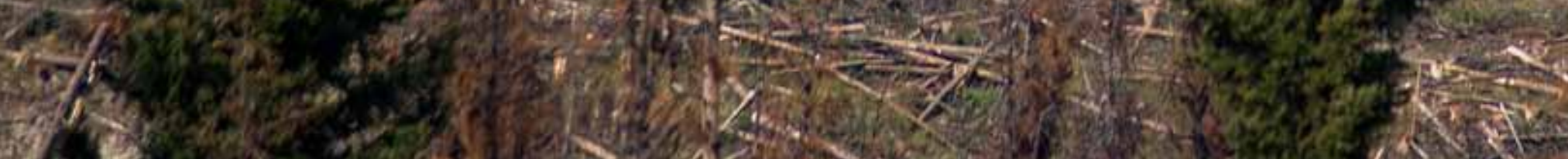

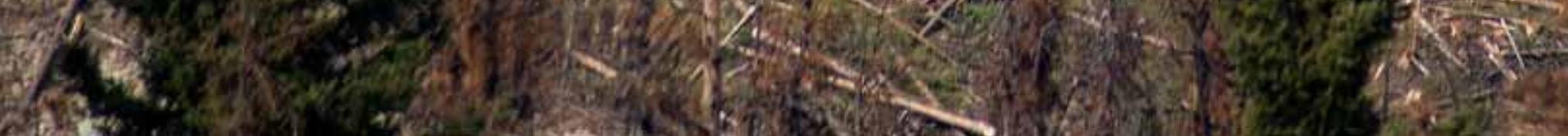




\section{THE FINANCIAL BENEFITS OF ECOSYSTEM RESTORATION - GREEN ECONOMY}

An analysis of 89 major ecosystem restoration projects worldwide concluded that ecological restoration increased provision of biodiversity and ecosystem services increased by 44 and $25 \%$, respectively (Benayas et al., 2009). Increases in ecosystem services and biodiversity were positively related. In a survey of managers of 3 I7 river restoration projects in the US, nearly two-thirds believed the projects to be completely successful. At the same time, a series of investigations have shown extraordinary high willingness to pay and support for restoration in certain public questionnaires, up to $78 \%$ of the interviewees, suggesting high awareness and low risk for these investments in terms of public feedback (Brander $e t a l$., 2006; Cao et al., 2009; Dehghani et al., 2010; Sodhi et al., 2010).

Table 4: Estimates of costs and benefits of restoration projects in different biomes

\begin{tabular}{|c|c|c|c|c|c|}
\hline \multirow[t]{2}{*}{$\begin{array}{l}\text { Biome/ } \\
\text { Ecosystem }\end{array}$} & $\begin{array}{l}\text { Typical cost of resto- } \\
\text { ration (high scenario) }\end{array}$ & $\begin{array}{l}\text { Est. annual benefits from } \\
\text { restoration (avg. scenario) }\end{array}$ & $\begin{array}{l}\text { Net present value of } \\
\text { benefits over } 40 \text { years }\end{array}$ & $\begin{array}{l}\text { Internal rate } \\
\text { of return }\end{array}$ & $\begin{array}{l}\text { Benefit/cost } \\
\text { ratio }\end{array}$ \\
\hline & USD/ha & USD/ha & USD/ha & $\%$ & Ratio \\
\hline Coral reefs & 542,500 & 129,200 & $1,166,000$ & $7 \%$ & 2,8 \\
\hline Coastal & 232,700 & 73,900 & 935,400 & $11 \%$ & 4.4 \\
\hline mangroves & 2,880 & 4,290 & 86,900 & $40 \%$ & 26.4 \\
\hline inland wetlands & 33,000 & 14,200 & 171,300 & $12 \%$ & 5.4 \\
\hline Lakes/rivers & 4,000 & 3,800 & 69,700 & $27 \%$ & 15.5 \\
\hline tropical forests & 3,450 & 7,000 & 148,700 & $50 \%$ & 37.3 \\
\hline other forests & 2,390 & 1,620 & 26,300 & $20 \%$ & 10.3 \\
\hline Woodland/shrubland & 990 & 1,571 & 32,180 & $42 \%$ & 28.4 \\
\hline Grasslands & 260 & 1,010 & 22,600 & $79 \%$ & 75.1 \\
\hline
\end{tabular}

Source: TEEB, 2009. Please note that there is substatial uncertainty with regard to these numbers. Updated figures are expected to be available by $2010 / 11$. 
However, while there is general public recognition of the benefits of restoration, policymakers needs to become more aware of the financial aspects associated with either conservation (where possible), restoration or, ultimately, continued degradation or loss of ecosystem services. In general the cost of conservation lies around $500 \mathrm{USD} / \mathrm{ha}$ on average (range $0.0 \mathrm{I}-\mathrm{I}, 000 \mathrm{USD} / \mathrm{ha} / \mathrm{year}$ ), compared to a few thousand to up to several hundred thousand USD/ ha in restoration costs for the same areas. These costs, however, are dwarfed by the cost of the services provided over decades, which amount to tens of thousands and even millions of dollars per ha. It is in simple terms much more financially profitable to protect than to restore where possible, but even restoration compared to loss provides a benefit/cost ratio of 3-75 in return of investments and an internal rate of return of $7-79 \%$. Thus, avoiding loss of ecosystems by initial conservation, particularly of forests, mangroves, wetlands and the coastal zone, including coral reefs, should be a primary objective from a cost-benefit analysis (Dodds et al., 2008).

As large shares of the world's ecosystems are already degraded or even lost, ecosystem restoration provides a low-risk, beneficial, cost-effective and financially sound investment providing excellent internal rates of return - and with high public aware- ness and support. The implementation, however, requires broad multi-sectoral and multi-staker involvement to ensure proper success. This relates also to careful consideration to payer-systems and public-private partnerships (Holl and Howarth, 2000), as multiple sectors will benefit.

The cost of conservation and required management, while highly variable, is typically USD $0.0 \mathrm{I}-\mathrm{I}, 000$ per hectare per year, commonly around IO-I5 USD/ha/year (). In comparison, the cost of restoration is from a few hundred dollars to 554,000 USD/ha for coral reefs as the most costly (TEEB, 2008, high scenario), compared to annual benefits from ecosystem services of I,OIo USD/ha/year to I29,200 USD/ha/year.

A survey of 62,108 river restoration projects in the US reported a total spending of I. 6 billion USD or an average of 25,76I USD per river (O'Donnell and Galat, 2007), with water quality improvement as the most common primary purpose. In comparison, 7.8 billion USD was invested in restoring the Florida Everglades ecosystem. It is however also important to monitor the effect of the investments and compare lower-intensity restoration with intensive restoration measures to evaluate the

\section{Ecosystem services value}

Bilion of US dollars per year, adjusted to 2010 inflation rate 13000

12000

11000

10000

Open ocean

9000

8000

7000

6000

5000

4000

3000

2000

1000

Estuaries

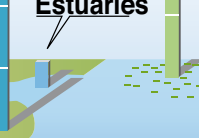

Figure 14: The values of ecosystem services (Costanza et al, 1998). 


\section{Rancho Humo: Wetland Restoration Model in Costa Rica}

Rancho Humo is a private reserve of 1068 hectares located in the lower basin of Tempisque River, one of the most important water systems in Costa Rica. It is surrounded by 30000 hectares of protected areas, including Palo Verde National Park and Barra Honda National Park and Wildlife Refuges Corral de Piedra, Mata Redonda and Cipancí. These wetlands were declared of International Importance under the Ramsar International Convention on the Palo Verde site.

The protection and restoration of wetlands in Rancho Humo is of vital importance to the area to function as a biological corridor between protected areas to be the interface between mangrove forests and the last holdouts of Mesoamerican tropical dry forest located in the highlands and limestone hills of the Nicoya Peninsula. Rancho Humo is an important feeding site for birds, including jabiru mycteria and falco peregrinus, endangered species under CITES. Additionally, it adjoins Isla Pájaros, Central

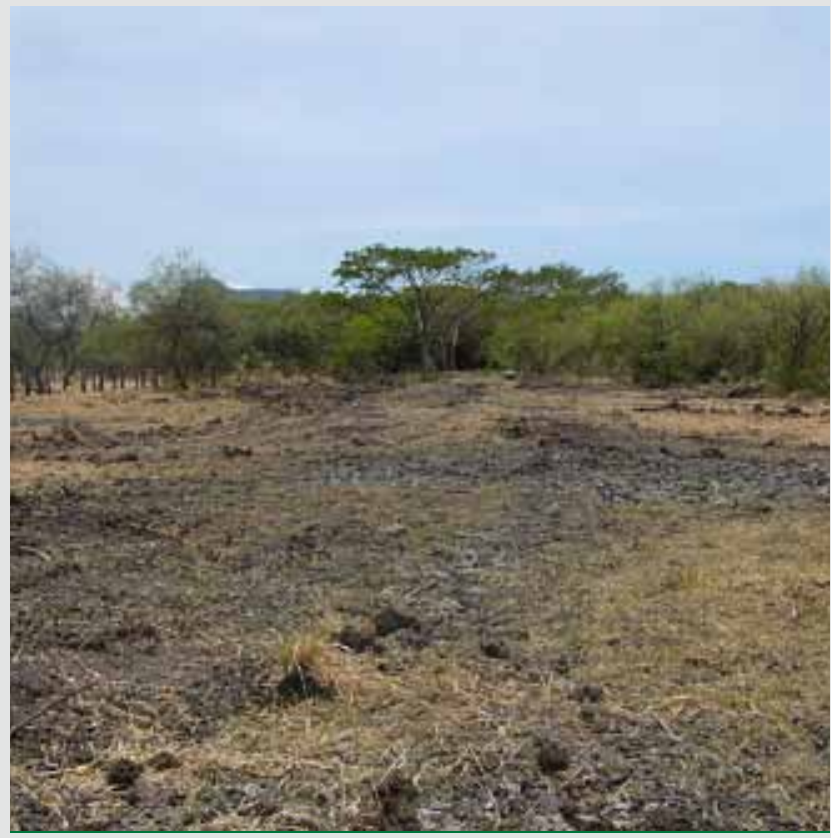

America's most important nesting colony of aquatic birds. The vast majority of fish species that feed the Gulf of Nicoya reproduce in these wetlands, contributing to sustain the health of the highest fish production site in the country, which guarantees the preservation of employment in the region and food source for the entire country.

Since 2006 Rancho Humo is undergoing a restoration process of 800 hectares of wetlands; diminished decades ago by extensive cattle ranching and subsistence agriculture held by the population of the area. This project has been conceived from its origins as a model sustainable development, involving communities in the process of environmental education and the principles of sustainable tourism; contributing to one of the most important pillars of Costa Rica's economy.

Source: M. Briceño, Rancho Humo, Personal communication, 2010.

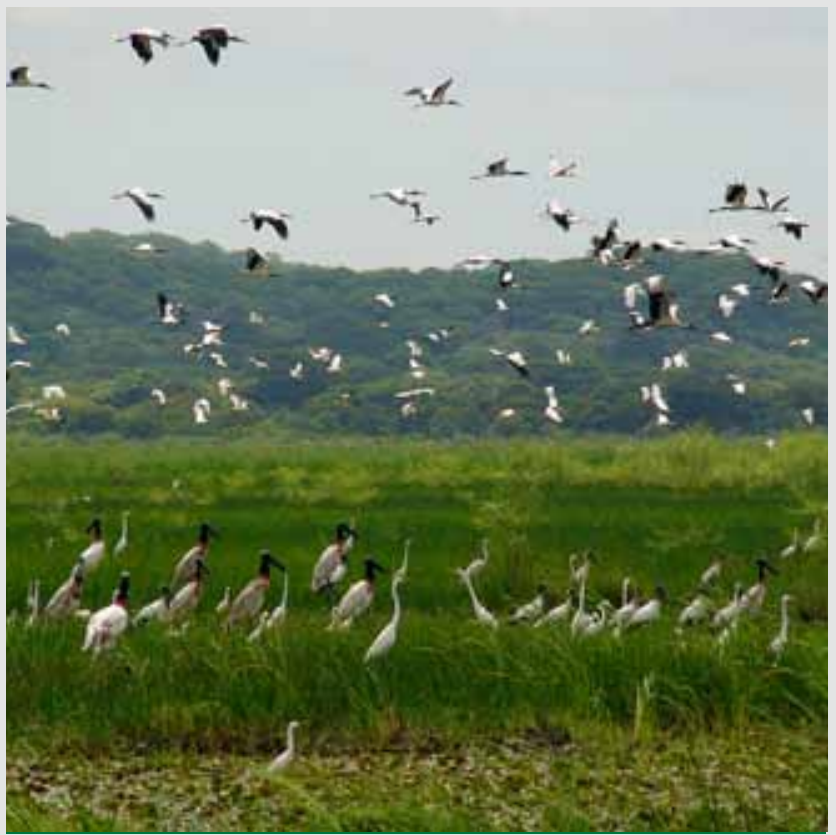




\section{Estimated costs and benefits of restoration projects in different biomes}

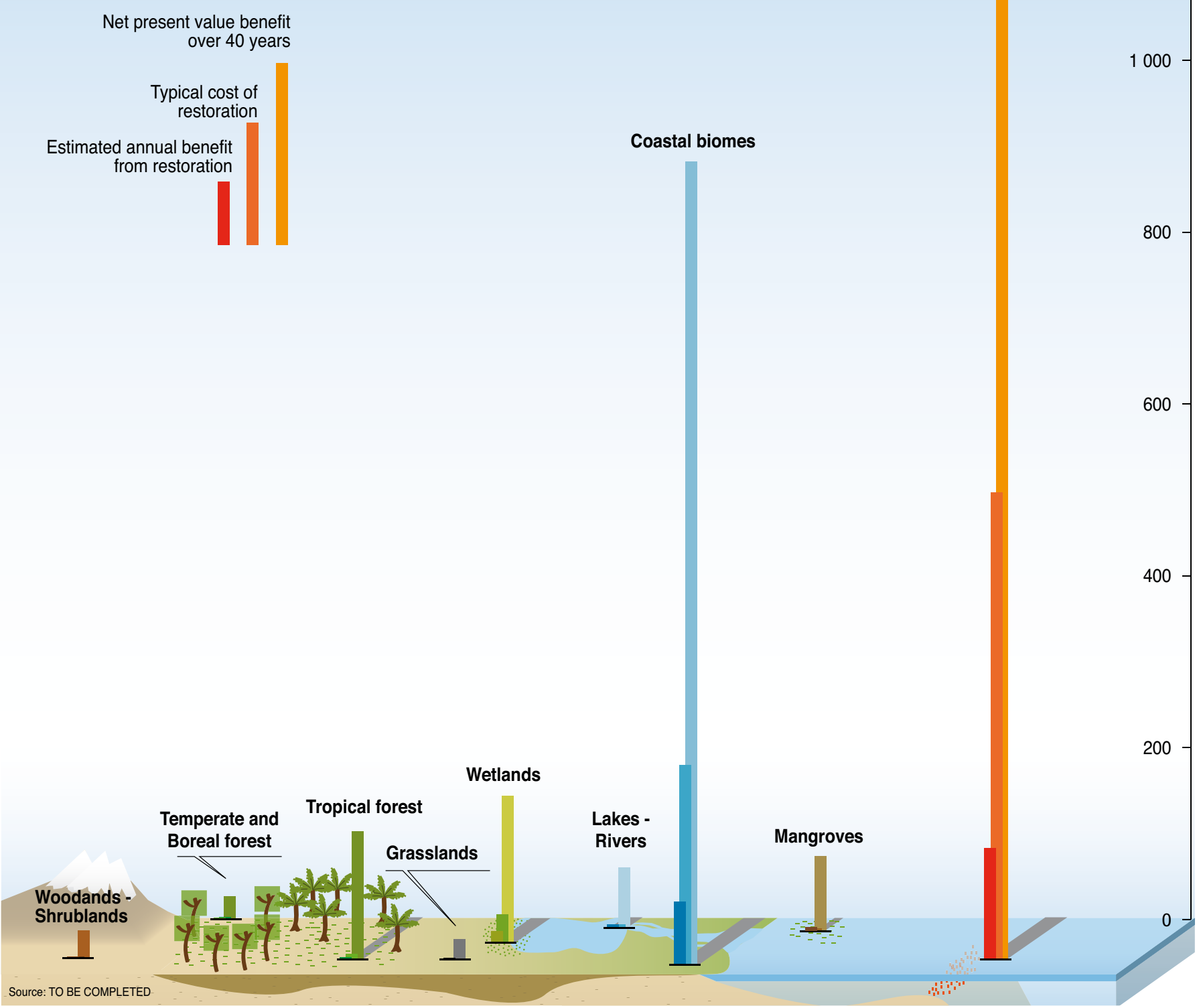

Figure 16: Costs and benefits of restoration projects. 


\section{RESTORATION AND RECOVERY OF ERODED AND OVERGRAZED ARID GRASS AND SHRUBLANDS}

Overgrazing, deforestation or cutting of shrubs for firewood are primary causes of land and wind erosion in drylands, such in the Sahel, Eastern and Southern Africa, Central Asia, China, ranges of Argentina and Chile, the Mediterranean and in southern and southwestern US (UNEP, 2006; Ibanez et al., 2007; Hoshino et al., 2009). In some areas, like in the Mediterranean and in Australia, where wildfires are common, not only aboveground biomass, but also root biomass, is extremely important, and restoration must carefully select or copy natural local vegetation to ensure that restoration efforts are not short-lived (De Baets et al., 2009). Shrubs, so crucial in drylands, dominating the largest share of the modest $15-30 \%$ total vegetation cover ( $\mathrm{Li} \mathrm{Xr}$ et al., 2009), must be a crucial component in restoration processes. In addition, it is often necessary to establish purely physical "dead" wind erosion networks to hinder erosion and establish a first barrier for creating viable conditions for plant growth. Where terrain with gullies and slope shave been overgrazed or cleared of vegetation, run-off and subsequent erosion (Descroix et al., 2008) or even flashfloods can have detrimental effects on both people, livestock, infrastructure and wildlife (UNEP, 2004, 2006). Restoring vegetation must also carefully address the initial causes of land degradation, such as overgrazing (Su et al., 2005, Zhang et al, 2005). Restoration is a particular valuable tool in drylands for restoring livable conditions for plants, wildlife and people, as

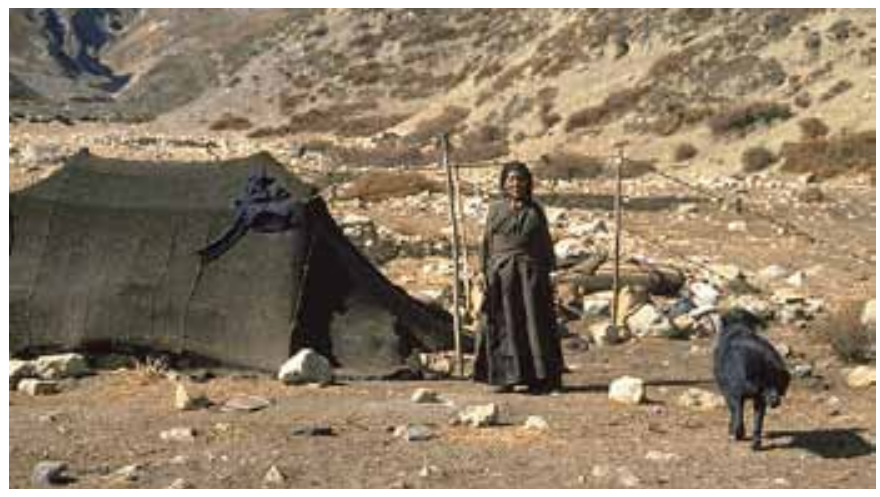

natural regeneration may take at least 50-300 years, and full restoration of ecosystem services as much as 3000 years (Lovich and Bainbridge, I999).

\section{Overgrazing near roads and villages in the Bayanbulak range, Xinjiang, China}

Vegetation cover, percentage

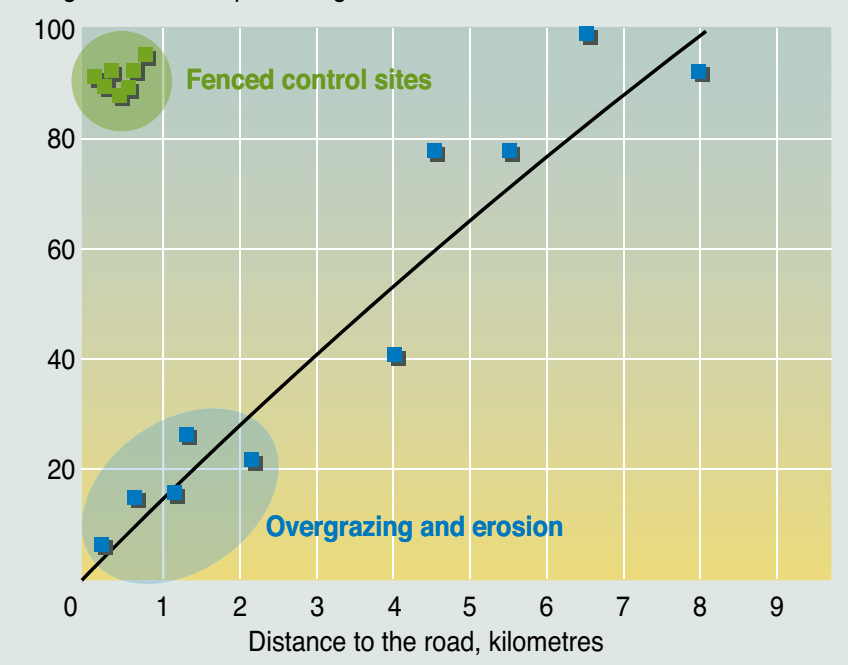

Source: Nellemann, C., et al., Fall of the water, UNEP, 2004.

Figure 17: Overgrazing by domestic animals concentrates along road corridors and new settlements, with resultant drop in grass coverage and increase in erosion on plains and slopes close to roads. Each black dot represents a randomly selected site (with five vegetation plots each) on the Bayanbulak range, East Tian Shan, Xinjiang, China. Fenced control areas protected against grazing across a 20 year period are shown as open circles. Areas impacted can however in some instances be up to $30 \mathrm{~km}$ from major settlements as those people that still retain more traditional lifestyles are forced to use more marginal lands in dry seasons $15-30 \mathrm{~km}$ away from their traditional now-occupied ranges close to new settlements (Source: UNEP, 2005). 


\section{CASE STUDY \#28}

\section{Erosion in drylands}

Overgrazing, deforestation or cutting of shrubs for firewood are primary causes of land and wind erosion in drylands, such in the Sahel, Central Asia, China, ranges of Argentina
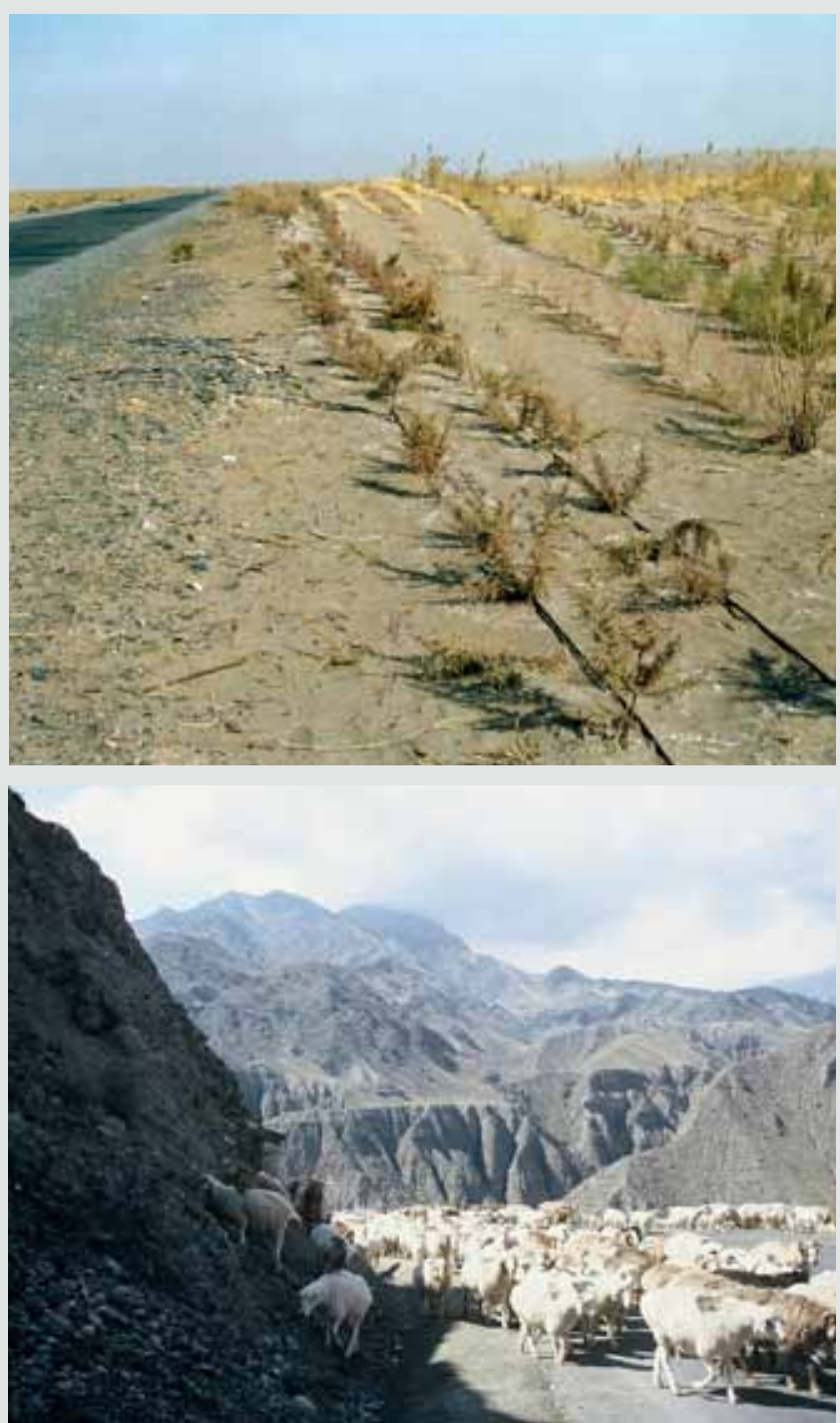

and Chile, the Mediterranean and in southern and southwestern US (UNEP, 2006; Ibanez et al., 2007; Hoshino et al., 2009).
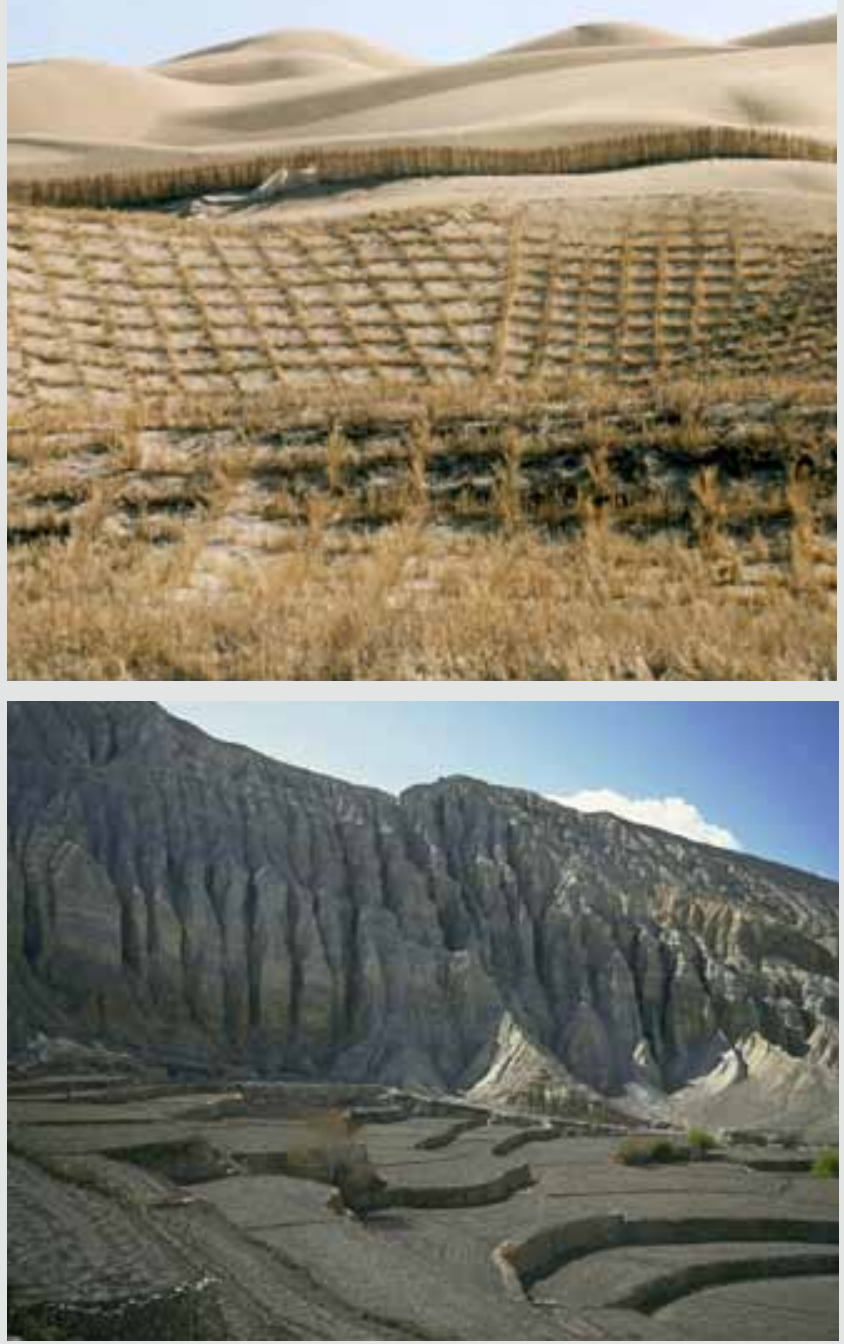


\section{Biorights - linking ecosystem restoration and livelihoods}

Ecosystem restoration is often constrained by the fact that at several instances, degradation or unsustainable resource use is often an outcome of short term livelihood need. This in turn deteriorates critical life-supporting ecosystem services. There is a need of approaches that can incentivize safeguarding natural resources through transfer of benefits that emanate from healthy ecosystems to communities. Wetlands International has pioneered an innovative financial mechanism called
Biorights which addresses poverty trap by integrating sustainable development and environmental conservation. In return for provision of micro-credits, local community involves in ecosystem protection and restoration. Upon successful delivery of conservation services, these microcredits are converted in definitive payments. Thus the approach enables community involvement in conservation while providing sustainable alternatives to harmful development practices.

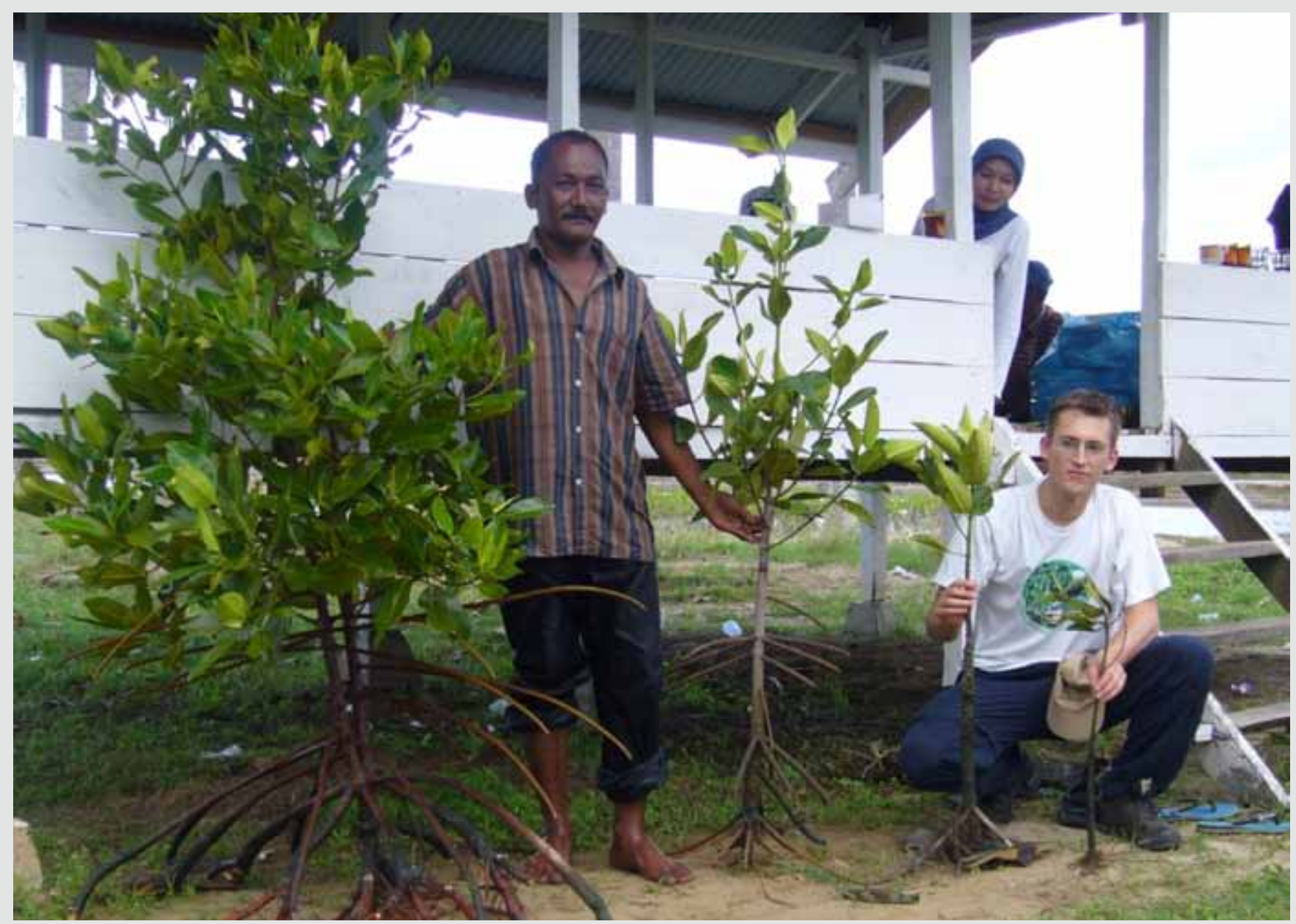


One of the early pilot sites for this approach was Central Java in Indonesia. Mangroves of the Pemalang District in Central Java fell prey to extensive development of shrimp culture in the 1980s, as was the trend in entire Southeast Asia. However, spread of disease led to rapidly declining productivity and ultimately abandoning of shrimp ponds by the investors, leaving behind completely devastated mangrove belts. Recognizing these challenges, a local NGO Mitra Bahiri, facilitated by Wetlands International and District Forest Agency initiated a mangrove restoration programme in late 1990s. In 1998, Biorights was introduced as an implementation approach. Community groups were formed and mangrove restoration plans were developed by these groups, which included identification of appropriate species and locations. Appropriate livelihood programmes were also selected by the communities based on development needs and local feasibility. Bioright contracts were developed with respective community groups. Intensive implementation support was provided in the form of technical expertise, capacity building and adaptation based on local conditions. Monitoring performed by local communities and local programme manager demonstrated survival rates well above $75 \%$ upon termination of the contract period, leading to conversion of all grants to definitive payments. Approximately 10 years after planting of the first seedling, the mangroves have grown into impressive heights of $4-8$ meters. Number of commercial fish species has increased from 2 to 6 . Slow land accretion is being observed. Local communities have also benefitted tremendously. Increase in household incomes and decrease in vulnerability have been recorded. Access to physical and financial capital has also increased. Although Biorights contracts have ended in 2005 , communities have continued with rehabilitation since then. Convinced of the benefits of restoration, the groups still meet to discuss restoration plans and have undertaken more ponds for rehabilitation.

When the Indian Ocean Tsunami of December 2004 badly hit the coastal areas of Sumatra, Wetlands International replicated the experiences of Java to restore mangroves in Aceh Province. Until June 2009, nearly 1000 hectares of coastal area has been rehabilitated (with an average seedling survival rate of around $83 \%$ or 1.66 million of the 2 millions planted) through the planting of mangrove and beach vegetation in Aceh and Nias. In the long run, this project will also contribute to the demand for climate change mitigation and adaptation and in return will leverage long-term improvements of local coastal ecosystem and ensuring long-term sustainability community livelihoods.

Source: Personal Communication Pieter van Eijk, Wetlands International; Nyoman Suryadiputra, Wetlands International - Indonesia Programme

\section{Forest habitat restoration on lle Aux Aigrettes, Mauritius}
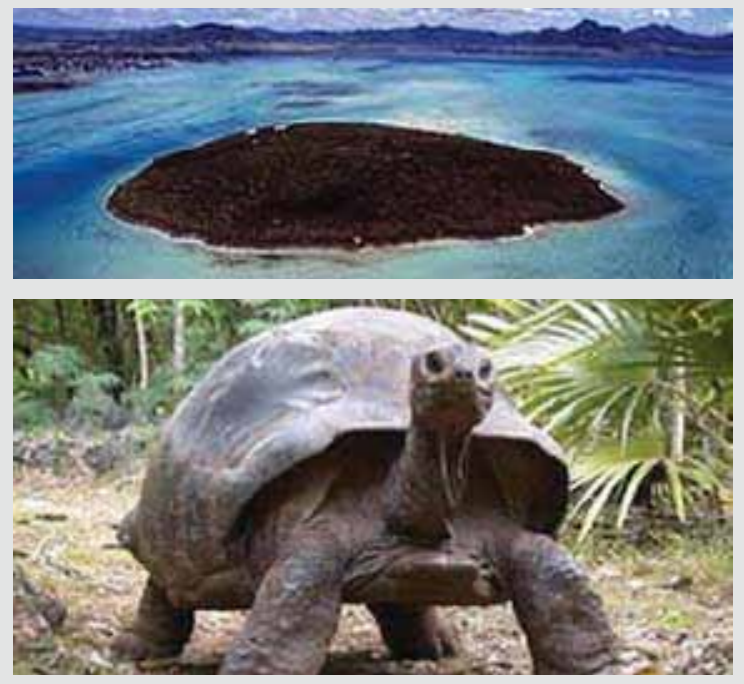

Managed and leased by the Mauritian Wildlife Foundation (MWF), Ile aux Aigrettes is a 25 -hectare island just off the southeast coast of mainland Mauritius that contains the last remnant of Mauritian coastal ebony forest. Exotic plant and animal species had driven the ecosystem to the brink of extinction by the 1980s, and it was then that MWF began its ongoing restoration program. Initial interventions included the removal of non-native plant species, revegetation with nursery-reared seedlings, and the eradication of rats, cats and mongooses. Several endemic and critically endangered species were subsequently reintroduced to the island, and diligent monitoring has reflected steadily increasing populations. Besides helping to conserve irreplaceable resources and safeguard Mauritius's natural heritage, MWF's work on Ile aux Aigrettes has made signifi cant contributions to local livelihoods. Activities directly associated with the restoration effort have afforded employment and training opportunities, and the development and promotion of ecotourism on the newly restored island has generated additional income for local communities.

Source: SER, 2010 http://www.globalrestorationnetwork.org/database/case-study/?id=265 


\section{ECOSYSTEM RESTORATION AND \\ REHABILITATION - LESSONS LEARNT}

There are several pitfalls that should be given carefull attention when attempting to restore ecosystems. These pitfalls include among other I) Unrealistic goals or changes in restoration targets in the process; 2) Improper and partial restoration creating monocultures with little ecosystem service capacity compared to reference sites; 3) Unintended transplant of non-native invasive pests or species; 4) Lack of monitoring to ensure that restoration does result in rising biodiversity and services in restored ecosystems; 5) Lack of reduction in initial pressures leading to the loss of the ecosystems in the first place; 5) Lack of adequate integration of stakeholders and socio-economic aspects.

There are numerous examples that non-native species becomes invasive pests. Restoration should therefore always carefully address and re-establish the endemic or natural species with particular attention also to potential contamination of specimen with unwanted diseases.

The goal of restoration is to set in motion process-based ecosystem recovery that leads to a regeneration and maintenance of resilient natural ecosystem processes. In turn, these processes generate desirable ecosystem structures (e.g. habitats) and linkages (flows and connectivity of sediment, water, nutrients and biota) and restore ecosystem functions (e.g. flood attenuation, shorebird habitat, fisheries, recreation, clean water maintenance and carbon sequestration). Because ecosystem restoration processes cover land, water, air interfaces and wetlands connect terrestrial, tidal and marine ecosystems, a major theme of any recovery plan is consideration of site-specific design and planning within the wider landscape context, including socio-economic aspects, a broad stakeholder community, adressing the initial pressures and not the least avoid new risks associated with unintended transplants of new species or pests.

Sometimes restoration is easy, the site has not been too heavily disturbed and a functional habitat rapidly returns. However, typically, substantial level of planning and design is often required to provide for cost-efficient and effective ecosystem rehabilitation, particularly in urbanized or fragmented landscapes.

Planning complexity can be increased when restoring large areas, though very attractive beneficial ecological and socioeconomic economies of scale result. Some simple lessons for ecosystem restoration and rehabilitation include (e.g. Simenstad and others, 2006; Crooks and Sharpe, 2007):

1) Develop a learning curve. Restoration should be based upon a clear understanding linking restoration actions, through physical processes to desired ecological outcome. 
2) Recognize the value of eco-engineering design. Investing in design work is sometimes seen as an unnecessary expense. However, an appropriate level of eco-engineering design can save construction costs, reduce the need for adaptive management or post-project remediation, and greatly improve the ecological value of the restored habitat. Given that land acquisition costs are often the largest financial burden to a restoration project, there is a positive benefit/cost ratio to restoring higher quality habitat per unit area of land,

3) Maximize geomorphic and ecological benefits. Restoring the physical integrity of the habitat offers the best opportunity for restoring ecological integrity. One key to effective restoration is preparing the site appropriately to encourage a natural evolution. Effective restoration allows for natural response to infrequent, dynamic disturbance events. Consideration of ecological functioning under atypical environmental conditions will increase restoration resilience.

4) Restore the landscape. Place restoration projects to maximize ecosystem mosaics and connectivity across a landscape, and with size of project economies of scale result. Restoring wetlands through an estuary and catchment can help maintain staging areas for migratory fish and birds, as well as support wider ecology, particularly in systems were this connectivity has been degraded or lost. Apparent redundancy of habitat elements is an important aspect of natural landscapes; during infrequent disturbance events, such as floods or fires, these less obvious habitat features may offer critical refugia. Restoration projects should be phases across a landscape and over time to maximize benefits of interim habitat as part of a landscape mosaic. In coastal areas space is a scarce and critical resource. On river floodplains removing levees and restoring wetlands reduces flood levels system wide leading to ecological benefits and reduced flood risk to local communities.

5) Involve the community. Community awareness, education and support greatly enhances the level of funding and political backing for habitat restoration activities. Community outreach, education and involvement are important of many successful restoration activities. Simple measures such as involvement with planting projects or stream clearance can help build awareness. In California, grassroots organizations such as "Save the Bay" have been particularly effective in educating local populations and keeping environmental restoration in the spotlight. Currently more than $70 \%$ of the Bay Area population not only support local wetlands restoration but are willing to pay additional taxes towards the process. Increasing level of public outreach may, over time, lead to shifts in public perception of restoration to one of a social gain rather than loss, and so lead to political support for widespread restoration. This is also crucial for addressing the initial pressures leading to degradation in the first place, such as pollution or unsustainable harvest.

6) Be patient and monitor. Ecosystem restoration takes time to progress along evolutionary trajectories and to re-establish complexity in form and function. However, delaying to restore a landscape can increase level of effort or result in restoration of former habitats being unachievable.

7) Avoid transplantation of non-indigenous species and diseases/pests - and pay particular attention to the risk of exotic species invasions, unintended transfer of diseases and pests, even when translocating apparently similar or identical species. 


\section{Transplanting and rehabilitating gorillas from eastern Democratic Republic of Congo, Rwanda and Uganda - a success in avoiding disease transfer}

Grauer's gorillas (Gorilla beringei graueri) are classified as "endangered" by the International Union for Conservation of $\mathrm{Na}$ ture's Red List, and, like mountain gorillas, are considered at high risk for extinction within several decades. A recent publication by UNEP and INTERPOL, supported by a series of scientists highlighted that perhaps less than 5,000 Grauer's gorillas may remain in the wild, down from over 17,000 in the mid 1990s, though challenged with scarcity of data in the conflict zone in Eastern DRC. The gorillas are at great risk due to the conflict in Eastern DRC, illegal logging, mining and habitat destruction, as well as threats from diseases or direct killing by militias as a result of park rangers attempting to halt the illegal burning and cutting for charcoal in gorilla habitats (UNEP, 2010).

The Gorilla Rehabilitation and Conservation Education (GRACE) center, Dian Fossey Gorilla Fund International (the Fossey Fund), in partnership with the Pan African Sanctu-

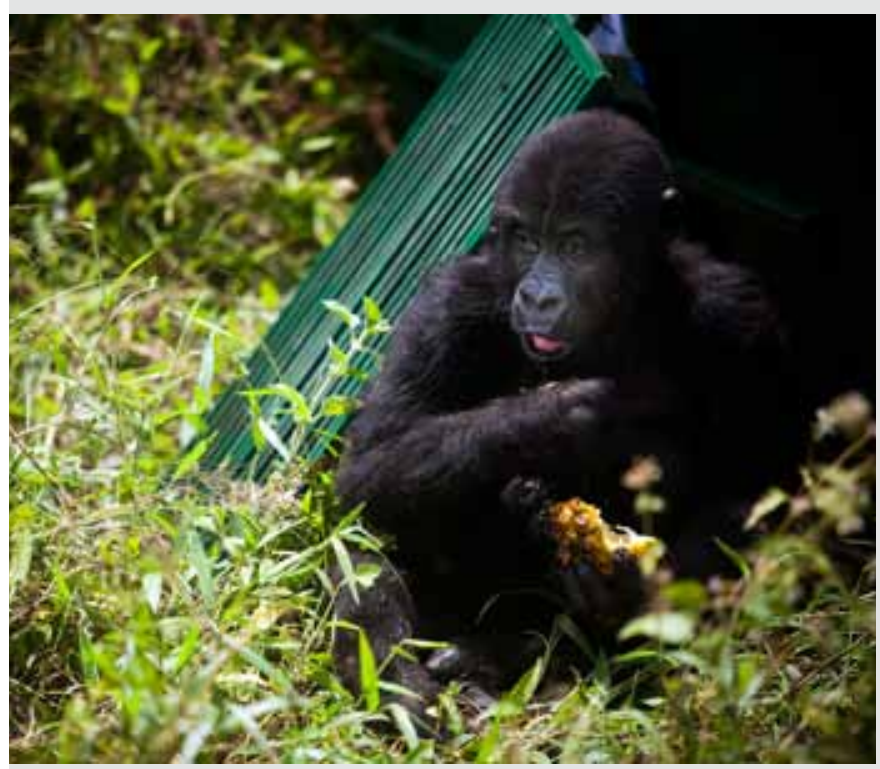

ary Alliance (PASA), Tayna College for Conservation Biology (TCCB), Disney's Animal Programs, the Disney Worldwide Conservation Fund, the U.S. Fish and Wildlife Service, and the national parks authorities of DR Congo and Rwanda, has established the first permanent rescue and rehabilitation center for orphaned gorillas in East Africa. The GRACE center is a project of the Fossey Fund's Africa Programs, but coordinates activities within a wide variety of partnerships.

A UNEP-INTERPOL report launched in March 2010 recommended strengthened involvement of the UN peacekeeping forces in halting illegal exploitation of resources financing the militia warfare and destroying gorilla habitats. On April 27th and on June 10th, 2010, MONUC, the UN peacekeeping forces in Eastern DRC, offered helicopter transport of a total of 10 orphaned gorillas rescued from poachers in Rwanda and Congo. The gorillas were airlifted by a Mi-8 to GRACE, the Gorilla Rehabilitation and Conservation Education Centre located at Tayna, Kasugho, DRC. The GRACE centre is located next to some 222,000 acres of forest in the fully protected community-managed Tayna Nature Reserve. The land for GRACE was donated by TCCB and is only $10 \mathrm{kms}$ from the Tayna Reserve. Hopefully, in the future when the gorillas are old enough and the security in the region prevails, the gorillas will be released into the Tayna Nature Reserve. The reserve was established by local Congolese leaders through a partnership with the Fossey Fund as part of a corridor of such reserves between Maiko and Kahuzi-Biega National Parks with Conservation International as the landscape leader. Tayna was the first reserve to obtain official protected reserve status from the Congolese national government. The GRACE centre will offer educational and economic resources to the people of the region, and will make a priority of training and hiring local people.

Re-introduction, rehabilitation and subsequent restoration of wild populations can involve risks including the spreading of diseases and must be given careful attention. One of the reasons for the success of the Fossey Fund and Mountain Gorilla Veterinary Project (MGVP), who have managed over the past 7 years to save all 
the orphans that have come into their care, has been strict protocols set by MGVP to reduce disease transmission and stress. The same risks of disease transmission in wild populations may be mitigated by the Fossey Fund's Ecosystem Health and Community Development program that works to eliminate parasites and other public health issues in the rural villages in close proximity to protected areas.
Contributors: Pan African Sanctuary Alliance (PASA); The Gorilla Rehabilitation and Conservation Education (GRACE) center; Tayna College for Conservation Biology (TCCB); Disney's Animal Program; Disney Worldwide Conservation Fund; U.S. Fish and Wildlife Service; Institut Congolais pour la Conservation de la Nature (ICCN) ; Office Rwandais du Tourisme et des Parcs Nationaux (ORTPN).

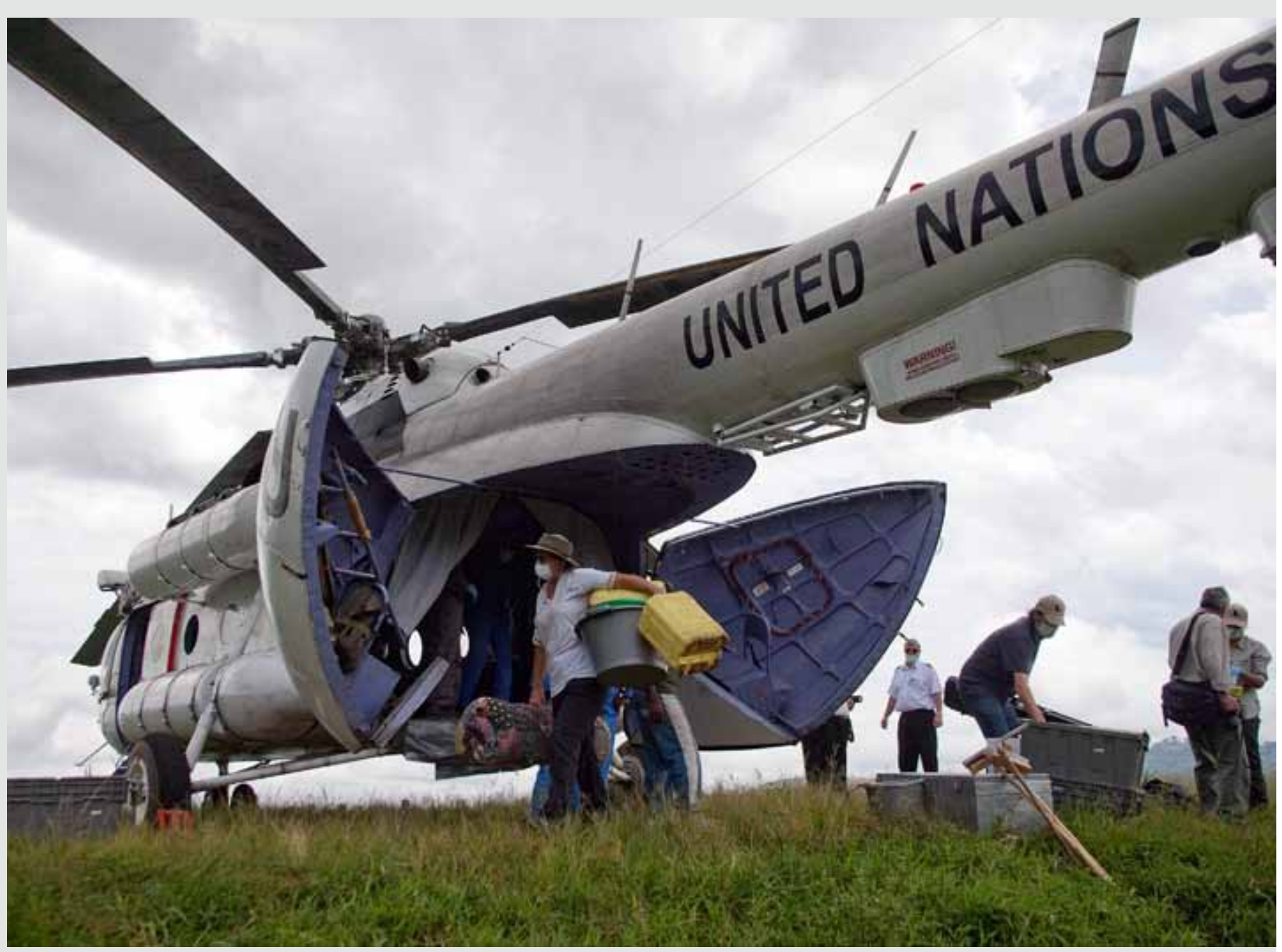




\section{Introduction of reindeer to Western Greenland - transplant of parasites to wild caribou}

In Western Greenland, where many West-Greenland caribou (Rangifer tarandus groenlandicus) populations had been depleted through excessive hunting, European wild reindeer (Rangifer tarandus tarandus) were introduced for the first time in 1952 to support this traditional food for local indigenous inuit hunters, for both herding and hunting (Cuyler, 1998). Reindeer and caribou are the same species (Rangifer tarandus), but different sub-species. However, the transplantation attempt also had one unintended result:
The reindeer from Europe brought with them the skin warble fly (Oedemagena furandi) and nasal bot fly (Cephenemyia trompe), which were not occurring in eastern Greenland at that time, and subsequently spread to the remaining wild caribou, which in turn led to deteriorated condition of the caribou and increased mortality rates (Klein, 1980). A similar case was observed with the disease Brucelloisis which apparently increased in wild caribou in Alaska's Seward peninsula after the introduction of reindeer (Klein, 1980).

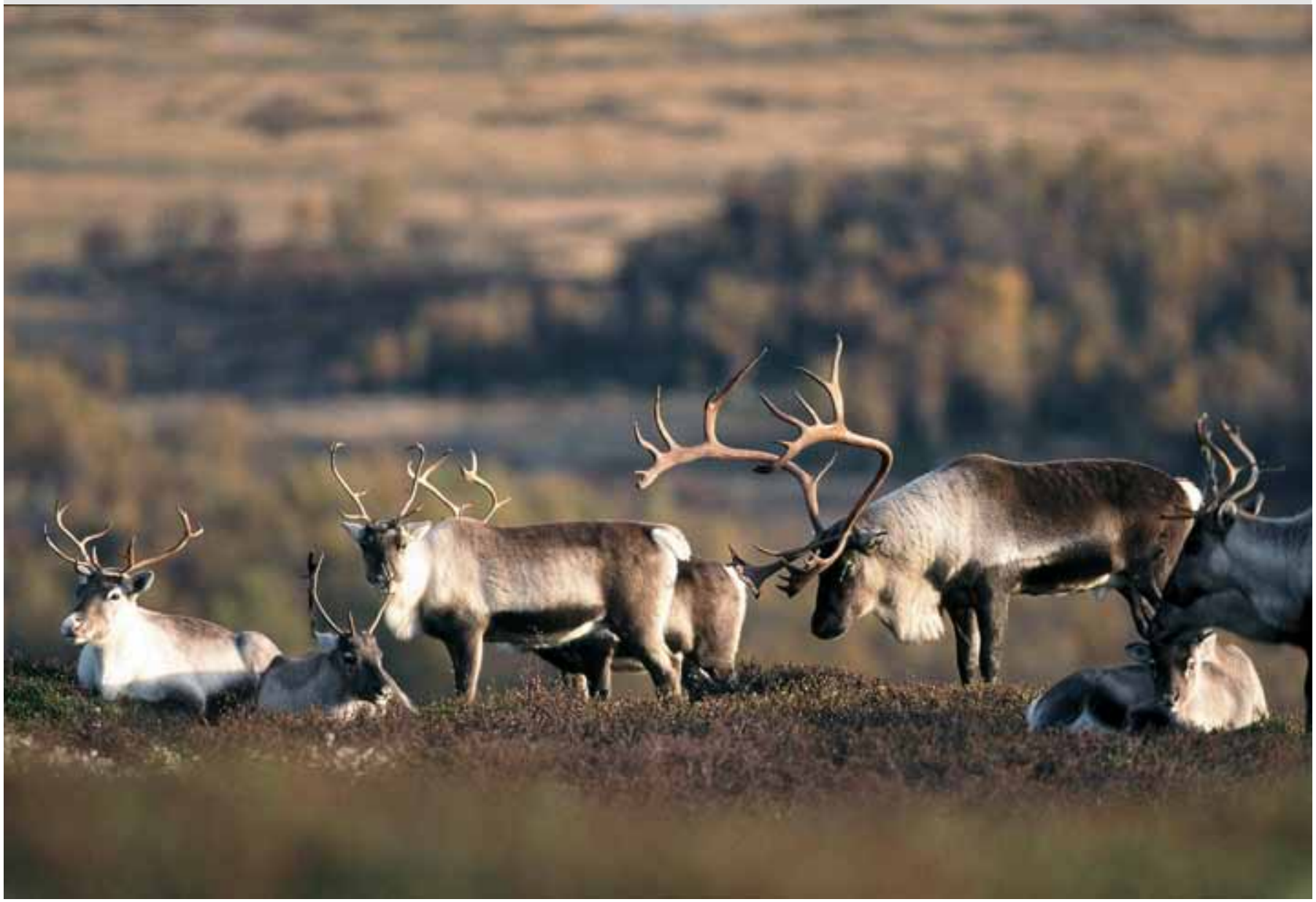




\section{Too good to be true? The dangers of short cuts to restoration in coral reefs}

Coral reefs cover only $0.2 \%$ of the sea floor and yet are amongst the most productive ecosystems on the planet. Close to shore and increasing human activity, they are disappearing rapidly. Nearly a fifth of all coral reefs have already been lost, a figure that could rise to above one third of all reefs within the next 20 years (Wilkinson, 2008). In addition to the long term and persistent pressures threatening the health of coral reefs, they are faced with periodic natural events, such as hurricanes, storm surges and destructive tsunamis.

The 2004 Indian Ocean tsunami devastated the region, wiping out whole communities, as well as infrastructure, of both the built and natural environment. In the aftermath, the international community attempted to respond to the many different needs of the affected countries. The coral reef community, through the International Coral Reef Initiative and its operational networks rallied to estimate the scale of the damage and to guide governments on the best course of action for sustained recovery (Wilkinson et al, 2006) in areas that depended heavily on their coral reefs for the services they provide such as supporting international tourism revenue and fisheries, the very things that underpin the livelihoods of these coastal communities. At a time where there was great pressure to act fast and rapidly assess and repair damage, a number of "too good to be true" solutions arrived on the market claiming to hold the answer to enhance coral reef recovery. As attractive as these solutions appear (from artificial reefs, to electric reefs, re-cemented reefs and transplantation) without comprehensive consideration of cost, scale scientific grounding and relevance these proposals can be inappropriate and distract from the principal task of improving management and reducing the chronic stressors that inhibit natural regeneration. In response to these concerns, the International Coral Reef Initiative Resolution developed guidance on artificial coral reef restoration and rehabilitation as well as assistance to help implement appropriate restoration of coral reefs.

The full document is available online at http://www.icriforum.org/sites/default/files/ICRI_resolution_Restoration.pdf.

Photo (C) Wolcott Henry 2005/Marine Photobank

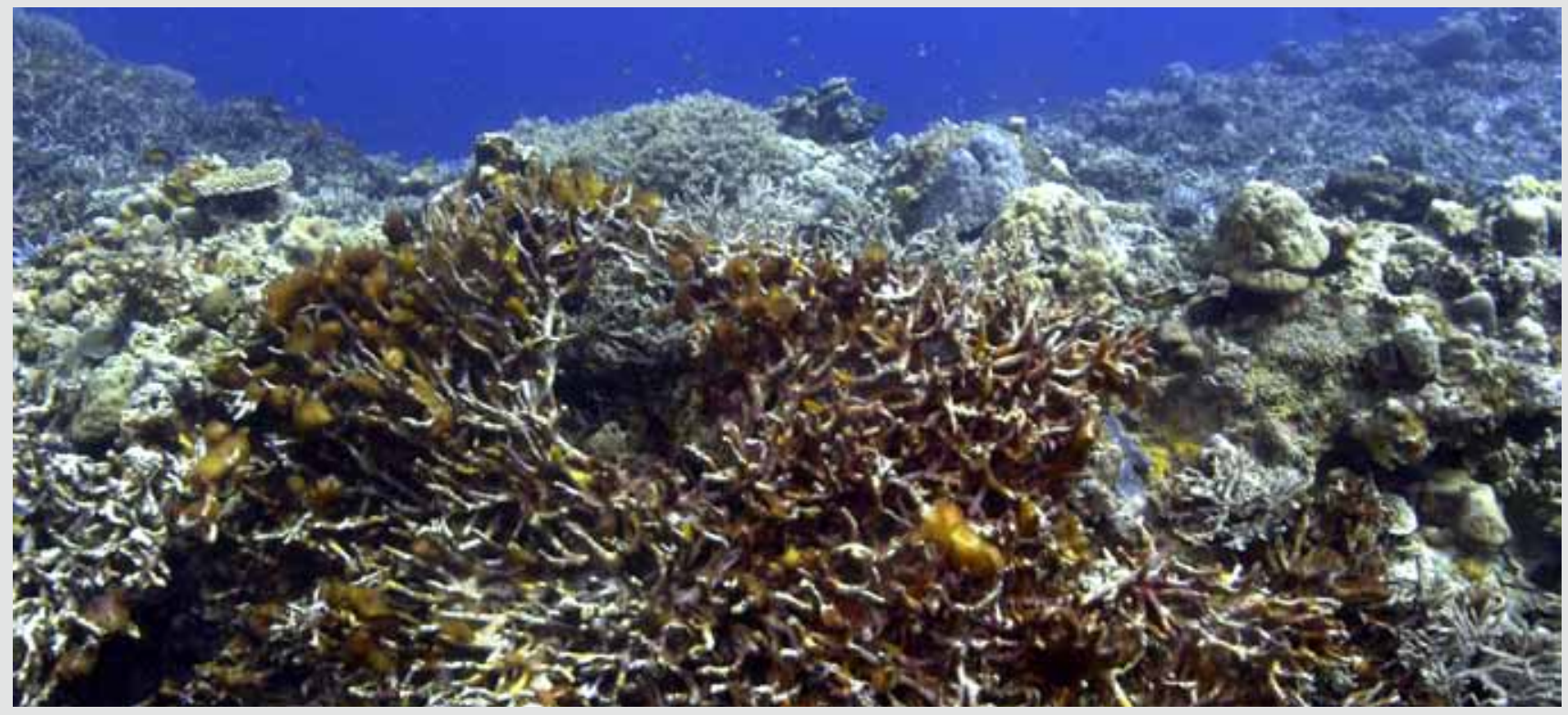




\section{Conservation, restoration and rehabilitation of fragmented wild reindeer populations in Norway: Successes and fallures}

Conservation efforts have secured the partial recovery of Europe's wild reindeer (Rangifer tarandus tarandus), although only in 24 separate fragments of their original range, now separated by resorts and roads (Nellemann et al., 2003; Vistnes and Nellemann, 2009). A unique science-based broad support in the parliament and by the Norwegian Government has resulted in a rise in protected areas, so important for the reindeer that otherwise reduce use or even entirely avoid areas subject to hydropower, roads and resorts. However, full recovery of the original range will require restoration of migration routes across developed or disturbed areas to reestablish former migration (Vistnes et al., 2004), especially under climate change where western areas may become increasingly inaccessible during winter due to extreme snow and ice conditions in the future.

Restoration of a major former military bombing range at Hjerkinn, Norway, has resulted in controversies over removal of former military road infrastructure, where local commercial and recreational interests want to use the road infrastructure for business development inside the National Park, thereby jeopardizing a key feature of the restoration goals, namely full rehabilitation of the lost winter ranges for wild reindeer in the region. Unless efforts are taken to fully implement the restoration goals, a failure could make this a classic textbook example of how restoration processes may fail when restoration targets are changed and partly lost during the restoration process.

This possible restoration failure is contrasted by the more strict conservation regime and restoration attempts in the vicinity of the neighboring national park in Rondane. Here, reindeer had generally avoided a 5-15 km zone around most resorts during winter due to extensive webs of recreational ski trails. A relocation and movement of both a major skitrails and a tourist cabin resulted in near immediate response in the reindeer distribution during winter: Reindeer moved into a formerly disturbed, but intact part of the winter range (Nellemann et al., 2009). By regulating trails and re-locating infrastructure, in this case trails and cabins, it was possible to effectively restore lost habitat while still promoting recreational development.

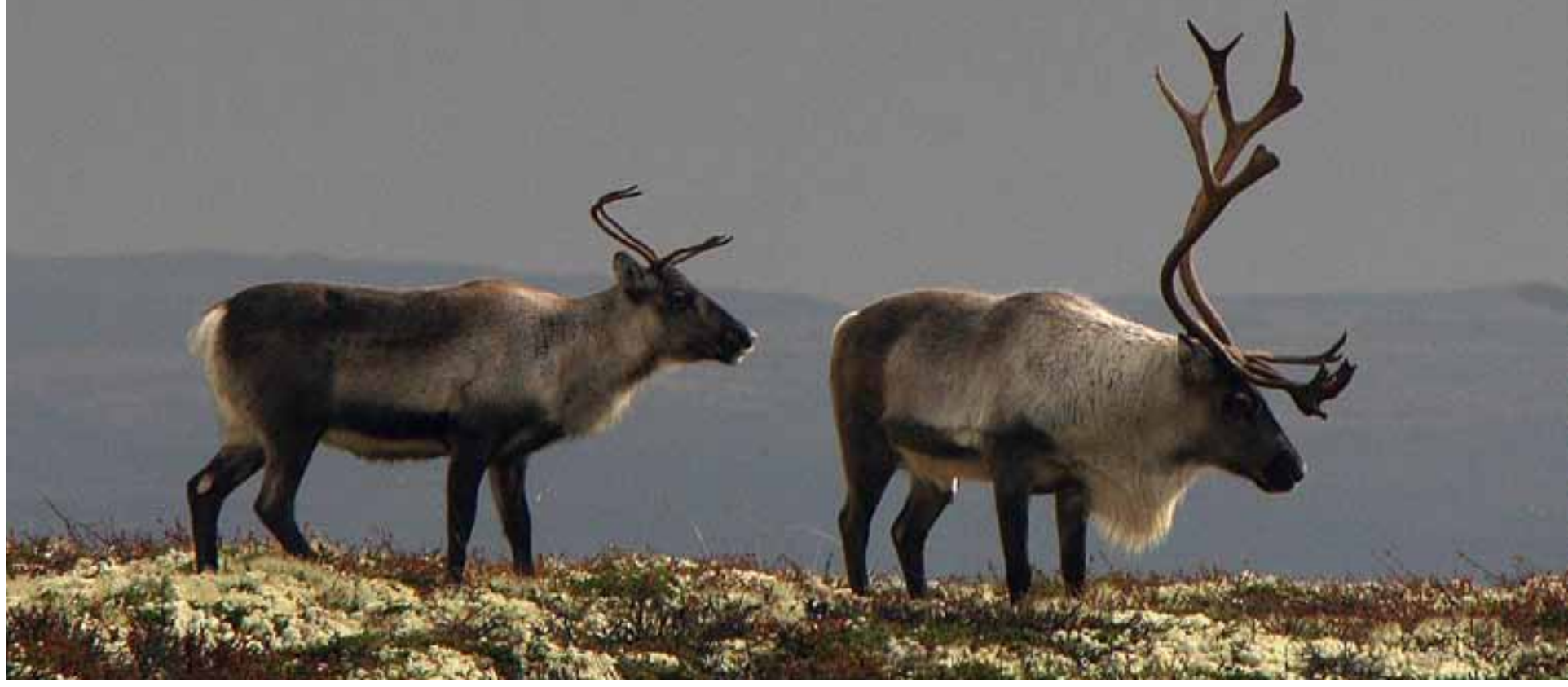




\section{RESTORATION OF A DEPLETED CRAYFISH FISHERY IN EUROPE - LESSONS LEARNT}

The world's biodiversity of freshwater crayfish are threatened by numerous factors, including loss and degradation of habitat, overharvesting, climate change and introduction of alien species of crayfish and associated diseases (Taylor 2002, Holdich et al. 2009), and more than one-third of the world's crayfish species are likely threatened with population decline or extinction (Taylor 2002). Ironically, introduction of alien crayfish species, also in restoration projects aiming to compensate for lost native stocks, is regarded among the most serious threats to indigenous crayfish populations (Taugbøl \& Skurdal 1999, Lodge et al. 2000).

The commercially important crayfish fisheries of Europe were heavily depleted during the last century, especially of the noble crayfish (Astacus astacus), which was reduced to near io \% of "historical" catches (Westman et al. 1990). One of the main reasons for this decline was the spreading of crayfish plague (Apahnomyces astaci) throughout Europe after its introduction in Italy in I859 (Söderhäll \& Cerenius I999), most likely as a result of importation of infected North American crayfish (Alderman \& Polglase I988).

In I959 a small batch of signal crayfish was introduced to Sweden from California, USA (Svärdson I995). The signal crayfish

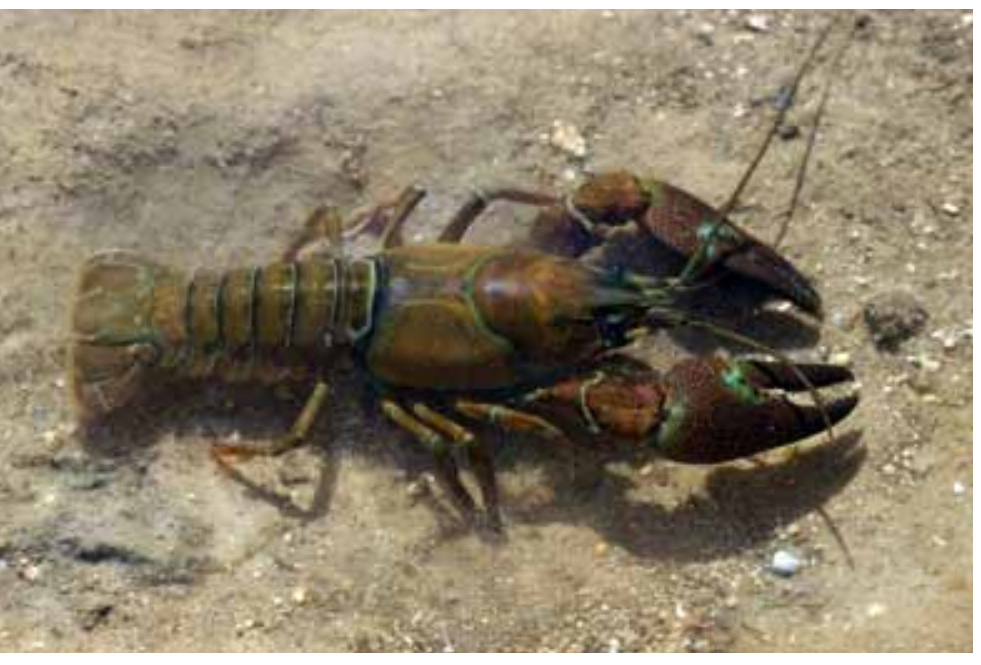

was considered resistant to the crayfish plague and to occupy the same ecological niche and therefore presumably able to restore the recreational and commercial important crayfish fishery in the plague affected areas. The fact that it was also a natural host of the oomycyte Aphanomyces astaci (the causative agent of crayfish plague) was probably unknown at the time (Unestam 1972). Trials were successful and in $1967-69$ a large number of signal crayfish were imported from USA and introduced into Swedish and Finnish waters (Svärdson I995, Westman 1995). These were followed by secondary introductions, mostly from Sweden, to many European countries (Lowery and Holdich 1988, Holdich et al. 2009). This led to an increase in the number of crayfish plague outbreaks, and $65 \%$ of the registered incidences of crayfish plague in Sweden from I9072004 have occurred after the increased introduction of signal crayfish from ig69 (Bohman et al. 2006)

To alleviate the problem of reduced stocks of indigenous species, the plague carrying North American species Orconectes limosus and Procambarus clarkii is also widespread in Europe, and are now established in 2I and I5 countries/territories respectively (Holdich et al. 2009)

In Europe, three of the five recognized indigenous species are on the IUCN red-list (Baillie \& Groombridge I996), and some countries are establishing "ark-sites" (secure sites) in an attempt to protect indigenous crayfish species (Sibley et al. 2007, Horton 2009). Restoration of many European crayfish fisheries with transplants of North American crayfish species may be regarded as a success in terms of establishing new plague resistant stocks for harvest (Ackefors I999), but has been detrimental for the indigenous crayfish species of Europe (Holdich et al. (2009). Extreme caution and careful planning must be conducted when restoring ecosystems to ensure the use of indigenous species and that no infestations or invasive species are introduced unintentionally.

$\rightarrow$ Figure 18: The distribution and main spreading route of the Signal crayfish in Europe. 


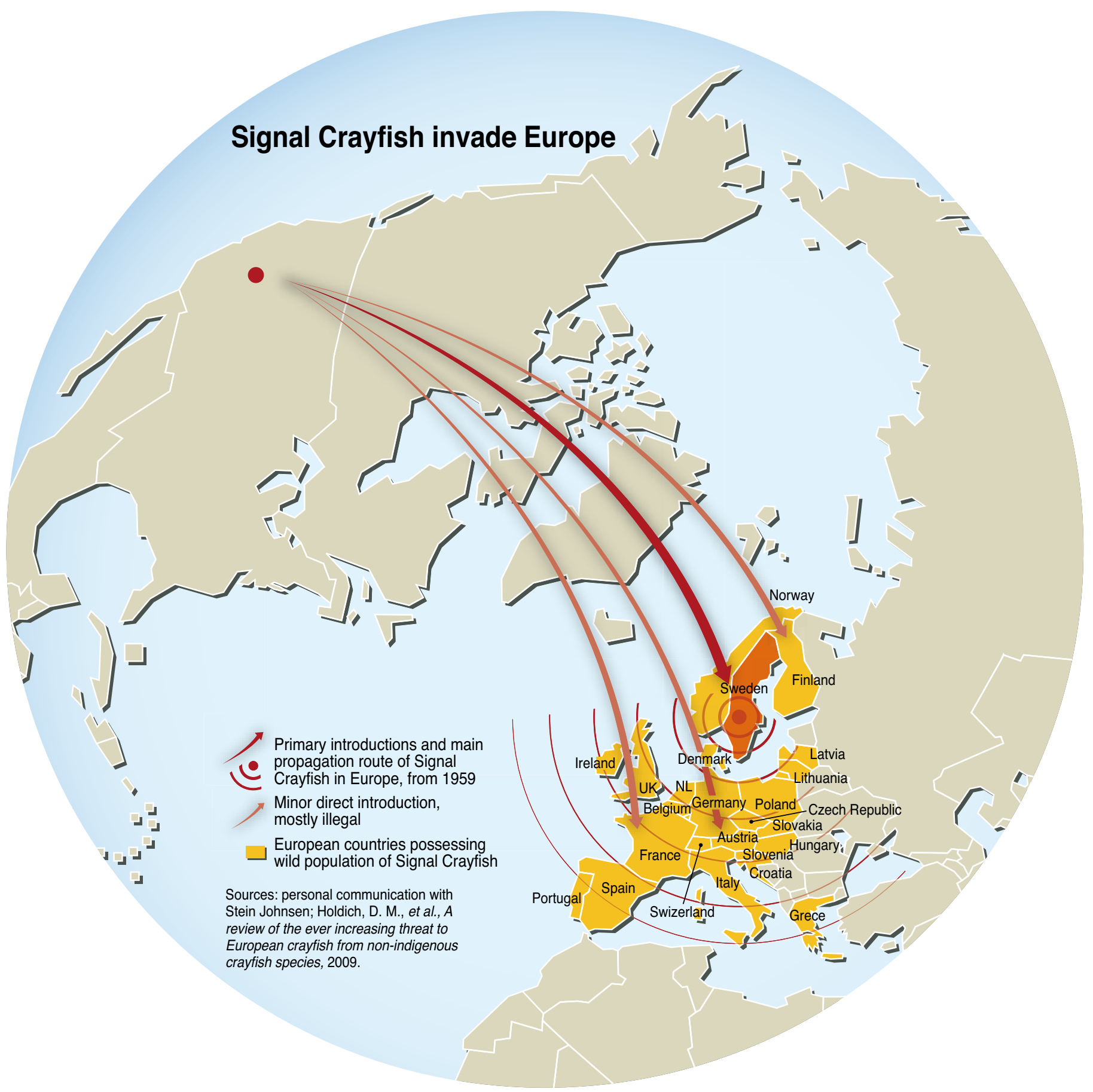

91 


\section{Use of traditional management - Forest Restoration in the Shinyanga Region, Tanzania}

In 1986, the government of Tanzania launched the Shinyanga Soil Conservation Programme (HASHI) with the aim of restoring severely degraded woodlands in the Shinyanga Region and providing local villagers access to important natural resources. Under this programme, the ngitili, a traditional resource management system, is being employed as the engine for remediation. Ngitilis are carefully managed tracts of land, held individually or communally, that are excluded from grazing during the wet season and then

used for fodder at the peak of the dry season. The ngitili has been found to represent an easily instituted and highly effective means of investing villagers in the long-term goals of restoration and conservation and ensuring the cooperation of village institutions at all levels of planning and implementation.

Source: SER, 2010 http://www.globalrestorationnetwork.org/database/casestudy/?id $=95$

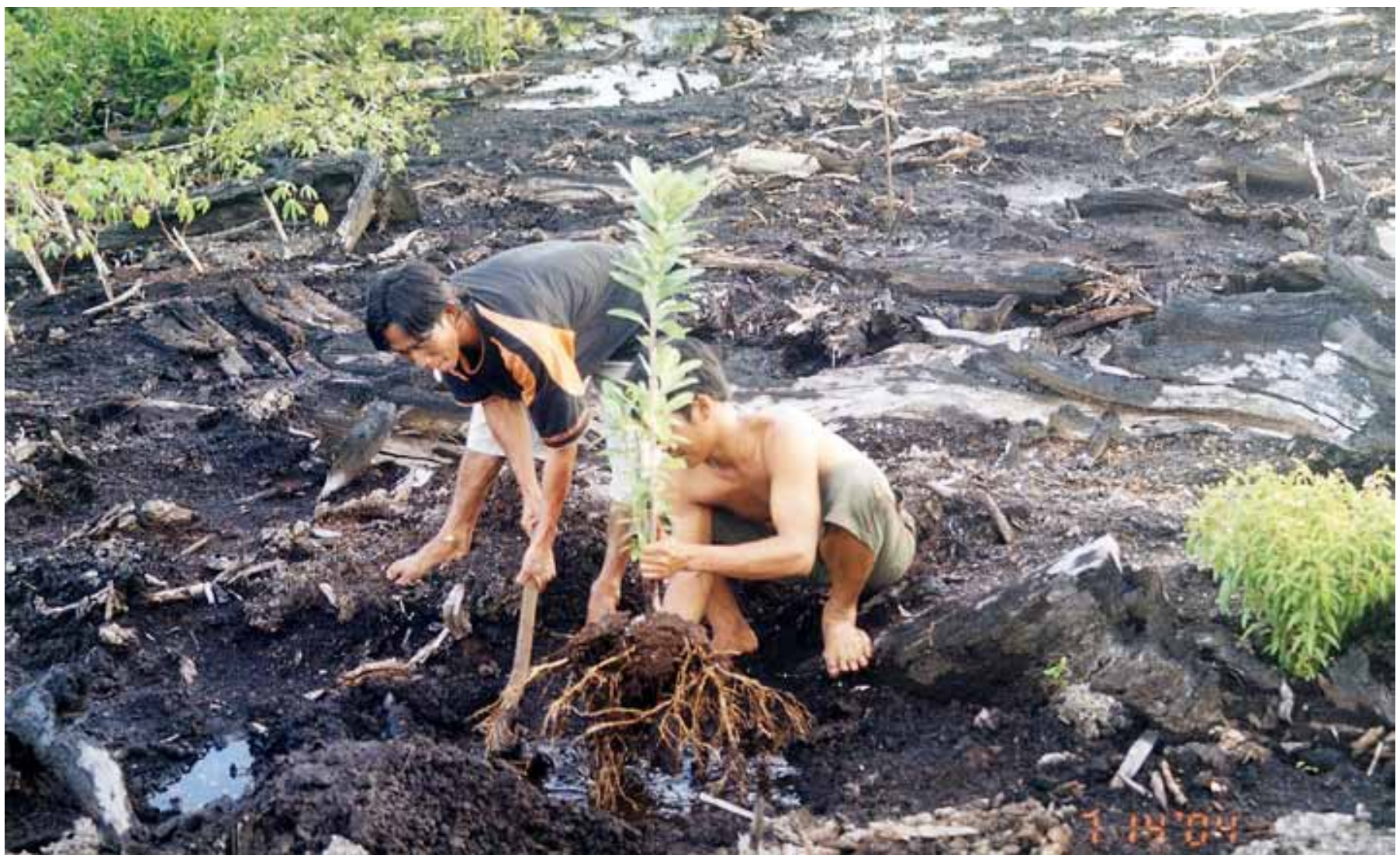




\section{Introduction and spread of the "Russian-Doll Salmon Killer" in Norway following salmon transplant}

Since its introduction the monogenean ectoparasite Gyrodactylus salaris has had devastating effects in Norwegian Atlantic salmon (Salmo salar) populations over the past four decades. In this period, the infection has spread to some 46 rivers. The parasite lives and reproduces in fresh- or slightly brackish water only, and the major mechanism for spread among geographically separate regions has been directly related to movement of live fish between rivers or hatcheries. Today's routines regulated by adjusted local legislation as well as EU legislation aims to preserve local populations and thus avoid mixing between geographically isolated strains as well as it aims to avoid spread of disease and pathogenic organisms. Unfortunately, a slip in these principles during the 1970'ies, led to the sad story of the "Russian-Doll Salmon Killer" in Norway.

Gyrodactylus salaris is found parasitizing several populations of salmon in the Baltic, a geographic region to which it is considered endemic. It was first observed in Norway in 1975. Later it has been concluded that it was introduced from the Baltic on several occasions, and that at least three of these introductions led to persisting epidemic outbreak (for recent literature, see e.g. Hansen et al. 2003 and Bakke et al. 2007). In Norway, the parasite generally reduces affected salmon populations by $80-90 \%$. In six populations, the parasite is considered having eliminated the salmon by driving the populations below sustainable density levels. Norwegian management authorities spend vast amounts every year on control measures

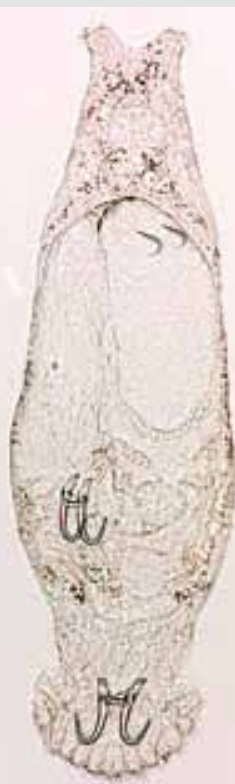

Gyrodactylus salaris has been referred to as the "Russian-Doll Salmon Killer" due to its mode of reproduction. Throughout their lifespan these hermaphroditic flukes they switch from asexual to sexual reproduction. A firstborn of an individual is always asexualIy derived. Furthermore, any newborn individual carries a nearly fully developed offspring inside, again carrying a developing embryo - thus the reference to a Russian-Doll. In the picture, the nearly fully developed attachment organ (the opisthaptor consisting of two large hooks; the hamuli and 16 smaller hooks; marginal hooks) of the daughter and the developing opisthaptor of the granddaughter can be seen. in attempts to eliminate the parasite and prevent further spread. It has been estimated that without control measures, reduction in Norwegian salmon fisheries would sum up to $15 \%$ (Johnsen and Jensen 2003).

All known introductions of $G$. salaris to Norway are results of transport of live fish. One of these transports was destined a central hatchery and farming facility from which salmon parr were distributed to several local hatcheries. In a recapture of the Gyrodactylus story in Norway, Johnsen and Jensen (1986) pointed out that of 14 geographically isolated regions in which $G$. salaris was found by 1985,11 had received fish from hatcheries that were secondarily infected from the central one. After establishment in new regions, further spread has in most cases probably taken place by fish movement through brackish water. Thus, the combination of lacking knowledge in the 1970'ies concerning the potential risks of moving even closely related fish stocks and the entering-point in a centralized hatchery turned out catastrophic.

The story of the "Russian-Doll Salmon Killer" in Norway has led to massive focus from parasitologists and freshwater biologists over the past four decades (see Bakke et al. 2007). Despite the lesson learned and increased knowledge gained, the occasional surprising discovery of the parasite on new hosts and in new localities gives an uncomfortable hint as to how little is really known about this and other potentially emerging diseases and pathogenic organisms. 


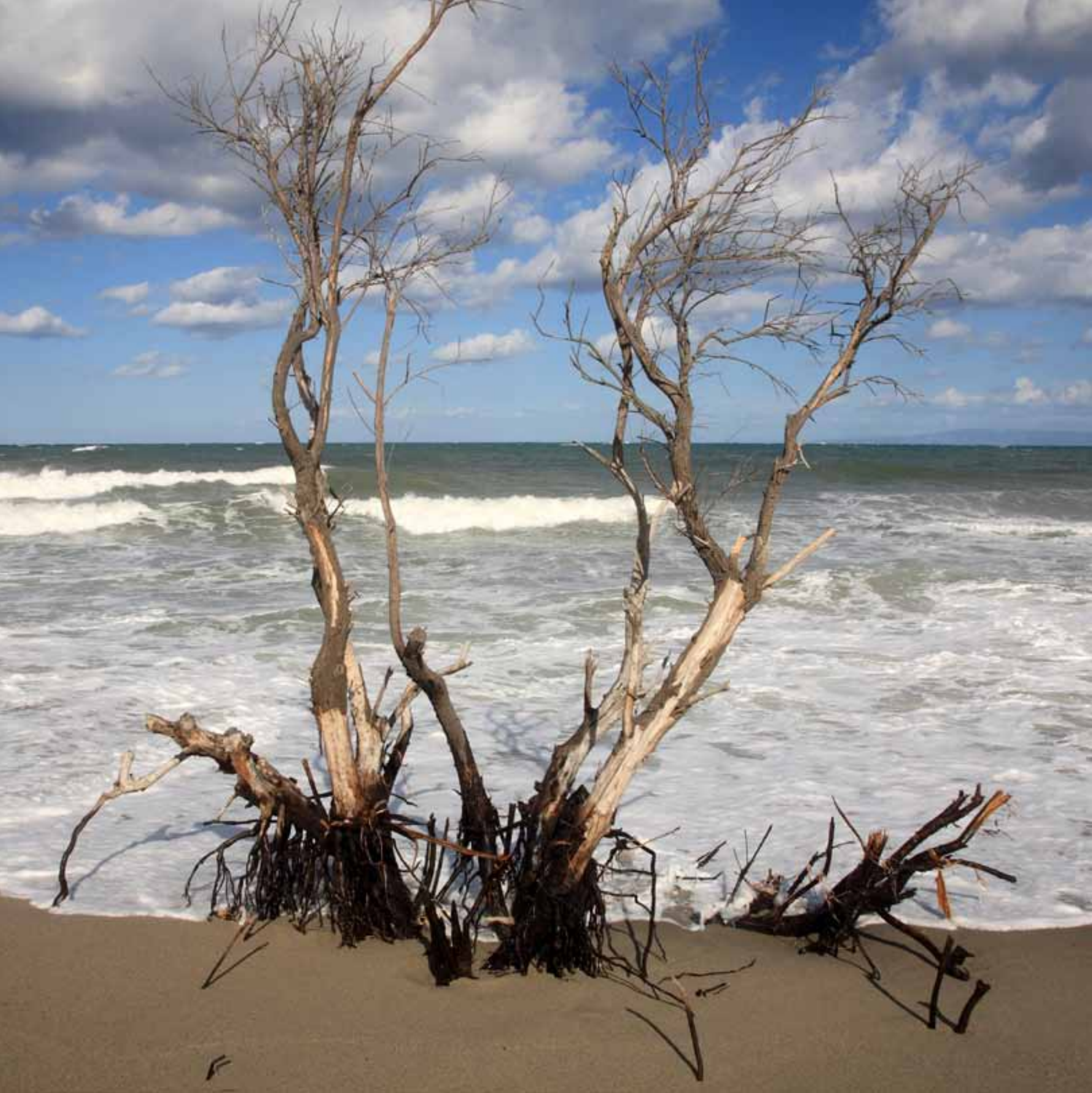




\title{
CONCLUSIONS AND RECOMMENDATIONS
}

\author{
Restoration is not a substitute to conservation, but if done with adequate planning and \\ multi-stakeholder involvement, can provide an effective tool for restoring lost ecosystem \\ services. The result should also provide great returns on these investments. However, \\ there are examples where restoration projects have failed or resulted in new problems \\ such as introducing pests or invasive species. The guidelines in this chapter are aimed at \\ reducing these risks.
}

Various guidelines for restoration projects have been developed, including strategies from the Society for Ecological Restoration (SER) International (SER, 20IO). While such guidelines are available, it is imperative to stress the importance of stakeholder involvement and particularly raising the awareness of services provided by the ecosystems and the current and future costs associated with their degradation and ultimate loss.

It is essential to raise awareness among the general public, policy makers and environmental managers on the crucial role ecosystems and biodiversity play in providing ecosystem services. This includes a particular focus on water filtration and supply, waste water cleaning, flood and storm barriers, pollination, nutrients, pest- and erosion control, food security and public health and poverty alleviation.

It is imperative that awareness is raised in relation to the costs associated with ecosystem degradation, lost labor productivity, lost incomes from tourism and increased expenses in production.

As many ecosystems are already degraded to some extent, of the cost-savings, benefits and not the least potential solutions to common political challenges that restoration can contribute to. Already at this stage it is important to consider the stakeholders involved.
If this awareness is available as the basis for decision making - the actual implementation process also requires direct considerations, which will vary highly from each specific site, case and stakeholders involved: This includes (adopted from SER, 2OIO):

Conceptual planning identifies the restoration project site, specifies its current state of health and the goals of restoration, and provides relevant background information including stakeholder involvement. Conceptual planning is conducted when restoration appears to be a feasible option but before a final decision has been made to exercise that option. Conceptual planning provides preliminary information on the habitat or ecosystem such as the identification of stressors, the extent/ health of its connectivity to the larger landscape, the need for engineering and biotic interventions, and representative measurements and surveys.

Preliminary tasks are those upon which project planning depends. These tasks form the foundation for well-conceived restoration project design. Preliminary tasks include the documentation of existing site conditions (biotic and abiotic) including baseline measurements, the establishment of a reference model to guide the project work towards its intended goals, planning for experimental plots within the large project, and the appointment of a project manager and team with expertise 
in all aspects of the project. Restoration should not follow a monolithic, top-down plan that treats all projects the same and should encourage public and stakeholder participation whenever possible. This is absolutely crucial for success.

Implementation plans describe the tasks that will be performed to realize project objectives. These tasks collectively comprise the project design that includes all activities, treatments, and manipulations to be executed, including decisions to avoid intervention. Performance standards and monitoring protocols are typically part of the project design that allow for projects to be evaluated and subjected to adaptive management practices.

Project implementation is the phase in which tasks are executed according to the project design. Project boundaries are demarcated and monitoring equipment is setup. Site maintenance and protection are also important during the implementation phase. Adaptive management as a restoration strategy is highly recommended, if not essential,because what happens in one phase of project work can alter what was planned for the next phase. This applies to social, cultural and economic outcomes as well.

Evaluation and publicity are also critical components of a successful restoration project. Thorough assessments are periodically necessary to ensure the on-going fulfillment of project objectives and goals. However, monitoring, adaptive management practices and site maintenance must be ongoing. The project is publicized for public outreach as well as academic and professional feedback.
1) Prioritize to protect biodiversity and ecosystem service hotspots, even when partially degraded, to halt further degradation and allow for restoration planning to commence. Conservation, within the context of spatial planning, provides by far the most cost efficient way to secure ecosystem services. This is particularly critical for areas with high degree of land pressures and development.

2) Ensure that investments in restoration are combined with long-term ecosystem management in both restored and in surrounding areas to ensure gradual recovery. Overseas Development Agencies, International finance agencies and other funders including regional development banks and bilateral agencies should factor ecosystem restoration into development support; job generation and poverty alleviation funding.

3) Infrastructure projects that damage an ecosystem should set aside funds to restore a similar degraded ecosystem elsewhere in a country or community. Payments for Ecosystem Services should include a proportion of the payment for the restoration and rehabilitation of damaged and degraded ecosystems. One percent of GDP should be considered a target for investments in conservation and restoration.

4) Apply a multidisciplinary approach across stakeholders in order to make restoration investments successful. Wise investments reduce future costs and future public expenses, but it is imperative that the driving forces and pressures behind the initial degradation are addressed in order to secure progressive recovery and that local stakeholders become involved and benefit from the restoration process.

5) Ensure that restoration projects take into account the changing world: Ecosystem restoration should be implemented in consideration of scenarios for change in 
a continually changing world, including climate change and land pressures. Changes in surrounding areas or in the prevailing environmental conditions will influence both the rate of recovery and ultimate restoration success.

6) Restoration needs to address a range of scales from intense hotspot restoration to large-scale restoration to meet regional changes in land degradation. Degree of biodiversity restored is often linked to quality of services obtained and is intrinsically linked to successful outcome.

7) Ensure that ecosystem restoration is implemented, guided by experiences learned to date, to ensure that this tool is used appropriately and without unexpected consequences, such as the unintended introduction of invasive species and pests and sudden abandonment of restoration targets in the process.

8) Apply ecosystem restoration as an active policy option for addressing challenges of health, water supply and quality and wastewater management by improving watersheds and wetlands, enhancing natural filtration.

9) Apply ecosystem restoration as an active policy option for disaster prevention and mitigation from floods, tsunamis, storms or drought. Coral reefs, mangroves, wetlands, catchment forests and vegetation, marshes and natural riparian vegetation provide some of the most efficient flood and storm mitigation systems available and restoration of these ecosystems should be a primary incentive in flood risk and disaster mitigation planning.

10) Enhance further use of ecosystem restoration as a mean for carbon sequestration, adaptation to and mitigation of climate change. The restoration targets for sequestration includes among other forests, wetlands, marine ecosystems such as mangroves, seagrasses and salt marshes, and other land use practices.
11) Improve food security through ecosystem restoration. Given the significance of food production and its relations to biodiversity and ecosystems loss, expanded recommendations are presented:

a. Strengthen natural pest control: Restoration of field edges, crop diversity and wild crop relatives, forests and wetlands is a tool for improving natural weed, pest and disease control in agricultural production. This should be combined with biological control including establishment and facilitation of natural predator host plants and insects, enzymes, mites or natural pathogens.

b. Improve and restore soil fertility: Research and Development funds into agriculture should become a primary investment source for financing restoration of lost and degraded soils, improve soil fertility and water catchment capacity, by investing in small-scale eco-agricultural, agro-forestry- and intercropping systems

c. Support more diversified and resilient agricultural systems that provide critical ecosystem services (water supply and regulation, habitat for wild plants and animals, genetic diversity, pollination, pest control, climate regulation), as well as adequate food to meet local and consumer needs. This includes managing extreme rainfall and using inter-cropping to minimize dependency on external inputs like artificial fertilizers, pesticides and blue irrigation water. Support should also be provided for the development and implementation of green technology for small-scale farmers.

d. Improve irrigation systems and reduce evapo-transpiration in intercropping and green technology irrigation or rainfall capture systems.

e. Improve water supply and quality and wastewater management in rural, peri-urban, and urban areas through restoration of field edges, riparian zones, forest cover in catchments, extent of green areas and wetland restoration. 


\section{Biodiversity (Contraction of biological diversity)}

The variability among living organisms from all sources, including terrestrial, marine, and other aquatic ecosystems and the ecological complexes of which they are part. Biodiversity includes diversity within species, between species, and between ecosystems.

\section{Land Use, Land Use Change and Forestry (LULUCF)}

A greenhouse gas inventory sector that covers emissions and removals of greenhouse gases resulting from direct human- induced land use, land-use change and forestry activities (UNFCCC 2009).

\section{Landscape restoration}

A broader range of issues and needs via a landscape-scale approach, "a planned process that aims to regain ecological integrity and enhance human wellbeing in deforested or degraded landscapes" (WWF International 2007).

\section{Mitigation}

A human intervention to reduce negative or unsustainable uses of ecosystems or to enhance sustainable practices (e.g. in the context of climate change reduce the sources of or enhance the sinks for greenhouse gases (Department of Climate Change 2008)).

\section{Progenitor}

A direct ancestor or pre cursor.

\section{Reclamation}

Reclamation aims to recover productivity (but little of the original biodiversity) at a degraded site. In time, the protective function and many of the original* ecological services may be reestablished. Reclamation is often done with exotic species but may also involve native species (WWF/IUCN 2000).

\section{Recovery}

Recovery of a habitat is linked to the ecological succession of a site. That is the site returning naturally to the state it had been before it had been degraded or destroyed without any intervention from humans (CFIOR websites).

\section{Regeneration}

The growth or re-emergence of the native species in a place after it has been destroyed or degraded, resulting from the protection of an area from biotic interference. Regeneration may come about naturally or result from human intervention (SER and CFIOR websites).

\section{Rehabilitation}

To re-establish the productivity and some, but not necessarily all, of the plant and animal species thought to be originally* present at a site. (For ecological or economic reasons the new habitat might also include species not originally present at the site). In time, the protective function and many of the ecological services of the original habitat may be re-established (FAO 2005).

\section{Restoration}

Re-establishing the presumed structure, productivity and species diversity that was originally present at a site that has been degraded, damaged or destroyed. In time, the ecological processes and functions of the restored habitat will closely match those of the original habitat (FAO 2005).

\section{Riparian}

Of, on, or relating to the banks of a natural course of water.

\section{Sequestration}

The removal of atmospheric carbon dioxide, either through biological processes (for example, photosynthesis in plants and trees, see Biosequestration), or geological processes (for example, storage of carbon dioxide in underground reservoirs) (Department of Climate Change 2008).

\section{Sink}

Any process, activity or mechanism that removes a greenhouse gas, an aerosol or a precursor of a greenhouse gas or aerosol from the atmosphere (IPCC 2007c).

\section{Source}

Any process, activity or mechanism that releases a greenhouse gas, an aerosol or a precursor of a greenhouse gas or aerosol into the atmosphere (IPCC 2007c).

\section{Sustainability}

A characteristic or state whereby the needs of the present and local population can be met without compromising the ability of future generations or populations in other locations to meet their needs (Chopra et al. 2005). 


\section{ACRONYMS}

$\begin{array}{ll}\boldsymbol{E} & \text { Euro } \\ \text { CO } & \text { Carbon Dioxide } \\ \text { CPI } & \text { Consumer Price Index } \\ \text { CWR } & \text { Crop wild relatives } \\ \text { EPA } & \text { Environmental Protection Agency } \\ \text { EU } & \text { European Union } \\ \text { FAO } & \text { Food and Agriculture Organization of the United Nations } \\ \text { GDP } & \text { Gross Domestic Product } \\ \text { GEF } & \text { Global Environment Facility } \\ \text { GHG } & \text { Green House Gas } \\ \text { GLOBIO } & \text { Modelling human impacts on biodiversity } \\ \text { GLOF } & \text { Glacial Lake Outburst Flood } \\ \text { Gt } & \text { Giga tonnes } \\ \text { Ha } & \text { Hectare } \\ \text { IAS } & \text { Invasive alien Species } \\ \text { IPCC } & \text { Intergovernmental Panel on Climate Change } \\ \text { IUCN } & \text { International Union for the Conservation of Nature } \\ \text { Km } & \text { Square Kilometres } \\ \text { MA } & \text { Millennium Ecosystem Assessment } \\ \text { MDG } & \text { Millennium Development Goal } \\ \text { N } & \text { Nitrogen } \\ \text { NGO } & \text { Non-governmental organization } \\ \text { REDD } & \text { The United Nations Collaborative Programme on Reducing Emissions } \\ & \text { from Deforestation and Forest Degradation in Developing Countries } \\ \text { SOC } & \text { Soil Organic Carbon } \\ \text { TEEB } & \text { The economics of ecosystems and biodiversity } \\ \text { UN } & \text { United Nations } \\ \text { UNEP } & \text { United Nations Environment Programme } \\ \text { UNEP-WCMC } & \text { UNEP World Conservation Monitoring Centre } \\ \text { USD } & \text { US Dollar } \\ \text { USA } & \text { United States of America } \\ \text { WHO } & \text { World Health Organization } \\ \text { WI } & \text { Wetlands International } \\ \text { Yr } & \text { Year } \\ & \end{array}$




\section{CONTRIBUTORS AND REVIEWERS}

Adrian Newton, School of Conservation Sciences, Bournemouth University, Fern Barrow, Talbot Campus, Poole, Dorset, ВНı2 5BB, UK

Ajit K. Pattnaik, Chilika Development Authority, Plot No. C-II , BJB Nagar, Bhubaneswar - 75IOI4, Orissa , India

Bruce Forbes, Arctic Centre, University of Lapland, Box I22, FIN-96ror Rovaniemi, Finland

Carlos M. Duarte, Department of Global Change Research, IMEDEA (CSIC-UIB), Instituto Mediterráneo de Estudios Avanzados Miquel Marqués 2I 07190 Esporles (Islas Baleares),Spain.

Carsten Neßhöver, Department of Conservation Biology, Helmholtz Centre for Environmental Research - UFZ, Permoserstraße I5, 043I8 Leipzig, Germany

Claire Brown, Nathalie Doswold, Abisha Mapendembe, Lucy Simpson, Emily Dunning, UNEP World Conservation Monitoring Centre, 2I9 Huntingdon Road, Cambridge, CB3 oDL, United Kingdom

Clare Richardson, Dian Fossey Gorilla Fund International, 800 Cherokee Ave., S.E. Atlanta, GA. 30315, USA

Deanna Rokich, Western Australian Ecology Centre, PO Box 48, Floreat, 6oI4, Western Australia

Debby Cox, Consultant, Dian Fossey Gorilla Fund-International Africa Programmes/Captive Care, International Primatological Society, 2ra Armidale Cres, Helensvale 42I2, Queensland, Australia

Francisco A. Comin, Instituto Pirenaico de Ecologia-CSIC, Spain

Georgina Langdale, TEEB, UNEP-Teeb Central Office, United Nations Campus, Hermann-Ehlers-Strasse Io, 53II3 Bonn, Germany
Gürdal Kanat, F. Ilter Aydinol Turkdogan, Environmental Engineering Department, Yildiz Technical University, 34349 Besiktas, Istanbul, Turkey

Heather M. Coleman, Bren School of Environmental Science and Management, University of California, Santa Barbara, CA 93106-5I3I, USA

Ibrahima Thiam, Wetlands International - Africa - Regional Director Rue III, Zone B, Villa N³9B BP 25 58I Dakar - Fann Senegal

Ingunn Ims Vistnes, Norut Alta - Áltá, Northern Research Institute, Alta, Norway

James Spurgeon, Environmental Economics Environmental Resources Management (ERM), Eaton House, Wallbrook Court, North Hinksey Lane, Oxford OX2 oQS, UK

Janet Skaalvik, Riccardo Pravettoni, Lawrence Hislop, Petter Sevaldsen, GRID-Arendal, Teaterplassen 3, 4836 Arendal, Norway

Johann Jenson, Johannes Refisch, UNEP, P.O. Box 30552 (ooroo), Nairobi, Kenya

José M. Rey Benayas, Dpto. de Ecología, Edificio de Ciencias, Universidad de Alcalá, 2887i Alcalá de Henares, Spain

Kevin Erwin, President and Principal Ecologist, Kevin L. Erwin Consulting Ecologist, Inc., 2077 Bayside Parkway,Ft. Myers, Florida 3390I USA,239.337.1505

Lifeng Li, Gang Lei, WWF-China, Room I6o9, Wenhua Gong, Beijing Working People's Culture Palace (Laodong Renmin Wenhuagong Dongmen), Beijing Ioooo6, P.R. China

Linda Redfern, Landscape \& Environmental Services, South Africa

Marcel Silvius, Susanna Tol, Pieter van Eijk, Wetlands International PO Box 47I, 6700 AL Wageningen, The Netherlands 
Mark Spalding, Philine zu Ermgassen, Global Marine Team, The Nature Conservancy and Department of Zoology, University of Cambridge, UK.

Melissa Briceño, Ranchohumo.com, Grupo Interamericano, Guanacaste, Costa Rica.

Monica Zavagli, Ramsar Secretariat, Rue Mauverney 28. CHII96 Gland, Switzerland

Norbert Hölzel, Institute of Landscape Ecology, Robert-KochStr. 28, D-48I49 Münster, Germany

Nyoman Suryadiputra, Wetlands International - Indonesia Programme Jl.Ahmad Yani No. 53, Bogor i6I6I, Indonesia

Ritesh Kumar, Wetlands International - South Asia, A-25, Second Floor, Defence Colony, New Delhi - IIo024, India

Robert Alkemade, Netherlands Environmental Assessment Agency (PBL), Nature, landscape and Biodiversity, P.O.Box 303, 3720 AH BILTHOVEN, The Netherlands

Sasha Alexander, Eric Higgs, Society for Ecological Restoration, Science \& Policy Working Group, IOI7 O Street NW, Washington, DC 2000I, USA.

Simone Haigh, Alan Cibilic, WetlandCare Australia, PO Box II4 Ballina NSW 2478, Australia

Stein Johnsen, Kjetil Olstad, Morten Kraabøl, Bjørn Petter Kaltenborn, Per Jordhøy, Norwegian Institute for Nature Research, Lillehammer, Norway

Steve Crooks, Climate Change Services, PWA, Philip Williams \& Associates | Environmental Hydrology, 550 Kearny Street, Suite 900, San Francisco, CA 94I08, USA

Terri Young, Jörn Scharlemann, UNEP World Conservation Monitoring Centre, 219 Huntingdon Road, Cambridge, CB3 oDL, U.K

\section{CARTOGRAPHY}

Riccardo Pravettoni

\section{LAYOUT \\ GRID-Arendal}

\section{PHOTO CREDITS}

1 iStockphoto/Jim Jurica 1 iStockphoto/Sarun Laowong 4 Lawrence Hislop 9 iStockphoto/Andrea Gingerich 10 iStockphoto/ooyoo 11 iStockphoto/ratluk 14-15 Marine Photobank/Ofir Avny 16 iStockphoto/P_Wei 20 iStockphoto/Johan Sjolander 23 iStockphoto/Claudia Dewald 29 iStockphoto/Warwick Lister-Kaye 36 iStockphoto/Maxim Chupashkin 42 iStockphoto/best-photo 50 iStockphoto/ Robert Churchill 53 Marine Photobank/Rebecca Weeks 58 iStockphoto/Mayumi Terao 68 iStockphoto/Tobias Helbig 72 Lawrence Hislop 76 Marine Photobank/Benjamin De Ridder 90 Wikimedia Commons/David Perez 92 Alue Dohong 94 iStockphoto/Blueplace 110 iStockphoto/Sasha Radosavljevic 112 iStockphoto/Jurjen Draaijer 
Ackefors, H. 1999. The positive effects of established crayfish introductions in Europe. In: Gherardi, F. and Holdich, D.M. (eds.), Crayfish in Europe as alien species - how to make the best of a bad situation?, A.A. Balkema, Rotterdam, 49-6r.

Alderman D.J. and Polglase J.L., I988. Pathogens, parasites and commensals. In: D.M. Holdich and R.S. Lowery (eds.), Freshwater crayfish: biology, management and exploitation, Croom Helm, London, I67-2I2.

Alkemade, R et al. 2009. GLOBIO 3 : A framework to investigate options for reducing global terrestrial biodiversity loss. Ecosystems I2: 374-390

Allen-Wardell et al. I998. The potential consequences of pollinator declines on the conservation of biodiversity and stabilityof food crop yields. Conservation Biology I2: 8-I7

Andrews, J.E.et al. 2008. Historical storage budgets of organic carbon, nutrient and contaminant elements in saltmarsh sediments: Biogeochemical context for managed realignment, Humber Estuary, UK. Science of The Total Environment 405: I-I3

Anser, J.P.et al. 2005. Selective logging in the Brazilian Amazon. Science 3I0: $480-482$

Aragón-Noriega, E. A. and Calderon-Aguilera, L.E. 2000. Does damming of the Colorado river affect the nursery area of blue shrimp Litopenaeus stylirostris in the upper Gulf of California? Revista de biologia tropical 48: 867-87I.

Arnaud-Haond, S. et al. 2009. Genetic recolonization of mangrove: genetic diversity still increasing in the Mekong Delta 30 years after Agent Orange. Marine Ecology Progress Series (in press).

Badola, R. and Hussain, S. A. 2005. Valuing ecosystem functions: An empirical study on the storm protection function of Bhitarnika mangrove system, India. Environmental conservation 32: 85-92.

Baillie J. and Groombridge B. (eds.), 1996. 1996 IUCN Red List of Threatened Animals.

Bakke et al. 2007. The Biology of Gyrodactylid Monogeneans: The "Russian-Doll Killers". Advances in Parasitology 64, I6I-376.

Bala, G. Et al. 2007. Combined climate and carbon-cycle effects of largescale deforestation. Proceedings of the National Academy of Science of the USA 104: 6550-6555.

Balmford, A. et al. 2004. The worldwide costs of marine protected areas. Proceedings of the National Academy of Science Ior: 9694-9697. URL: http://www.pnas.org/content/IOI/26/9694. full.pdf+html (last access Nov 6, 2009).

Barrow, E. 2005. Coordinator, Forest Conservation and Social Policy, Eastern Africa Regional Office, IUCN The World Conservation Union. Personal Communication. E-mail. January 26, 2005.

Barrow, E., and W. Mlenge. 2004. Ngitili for Everything-Woodland Restoration in Shinyanga, Tanzania. Dar es Salaam: The United Republic of Tanzania Ministry of Natural Resources and Tourism and IUCN The
World Conservation Union, Eastern Africa Regional Office

Barry, R.G., Chorley, R.J. I998. Atmosphere, weather and climate. 7th Edition. Routledge, London.

Batchelor, T. P. Et al. 2005. Insect gladiators II. Biological control 33: I94-I55.

Batey, T. 2009. Soil compaction and soil management: A review. Soil use and management 25: 335-345.

Beck, M. W. et al. 2009. Shellfish Reefs at Risk: a global analysis of problems and solutions (The Nature Conservancy, Arlington, VA, 2009).

Benayas, J.M. R, et al. 2009. Enhancement of biodiversity and ecosystem services by ecological restoration: a meta-analysis. Science 325: I2I-I24

Beniston, M. 2003. Climatic change in mountain regions: A review of possible impacts. Climatic Change 59: 5-31.

Bianchi, F. J. J. A. et al. 2006. Sustainable pest regulation in agricultural landscapes: A review of landscape composition, biodiversity and natural pest control. Proc. Of the Royal Society Biological sciences 273: I7I5-I727.

Bohman, P.et al. 2006. The effect of the large-scale introduction of signal crayfish on the spread of crayfish plague in Sweden. Bulletin Francais de la Peche et de la Pisciculture (380-38I), pp I29I-I302.

Bonan, G.B. 2008. Forests and climate change: forcings, feedbacks, and the climate benefits of forests. Science 320: I444-1449.

Boorman, L.; Hazelden, J. I995. Salt marsh creation and management for coastal defence, in: Healy, M.G.; Doody, J.P. (I995). Directions in European coastal management. pp. I75-183

Borum, J.,et al. 2004. European seagrasses: an introduction to monitoring and management. The M\&MS project, Copenhagen. ISBN: 87-891432I-3, $95 \mathrm{p}$.

Bouillon, S. et al. 2008. Mangrove production and carbon sinks: A revision of global budget estimates. Global Biogeochemical Cycles 22: GB2OI3.

Bouman, B. A. M. et al. 2007. Rice and water. Advances in agronomy 92: $187-237$

Braimah, H. and van Emden, H. F. 2oIo. Prosepcts and challenges for sustainable development of the mango stone weevil, Sternochetus mangiferae in west Africa: A review. International journal of pest management 56: 9I-IOI.

Brander, L. M. et al. 2006. The empirics of wetland valuation: A conprehensive summary and a meta-analysis of the literature. Environmental and resource economics 33: 223-250

Brown, M. J. F. and Paxton, R. J. 2009. The conservation of bees: A global perspective. Apidologie 40: 4I0-4I6

Bruijnzeel, L. A. 2004. Hydrological functions of tropical forests: Not seeing soil for trees? Agricuklture ecosystems and environment I04: I85228.

Cao, S. X. et al. 2009. An investigation of Chinese attitudes toward the environment: Case study using the grain for green project. Ambio 38: 55-64. 
CBD. 200I. Status, impacts and trends of alien species that threaten ecosystems, habitats and species. CBD, Montreal. Available online at: http:// www.cbd.int/doc/meetings/sbstta/sbstta-o6/information/sbstta-o6-inf-IIen.pdf [Accessed on the 20 January 2009].

CBD. 2008. Cross-roads of Life on Earth: Exploring means to meet the 20I0 Biodiversity Target. Secretariat of the Convention on Biological Diversity, Montreal, Technical Series no. 3I. Available online at: http://www. mnp.nl/bibliotheek/rapporten/55505000I.pdf [Accessed on the 20 January 2009].

CBD. 20I0. Global biodiversity outlook 3. Gbo3.cbd.int

Cebrián, J. and Duarte, C.M. I996. Plant growth-rate dependence of detrital carbon storage in ecosystems. Science 268: 1606-1608.

Chazdon, R. L. et al. 2008. Beyond deforestation: Restoring forests and ecosystem services on degraded lands. Science 320: I458-I460.

Chazdon, R.L. 2008. Beyond Deforestation: Restoring Forests and Ecosystem Services on Degraded Lands Science 320: I458-1460.

Chenje, M. and Katerere, J. 2006. Chapter Io: Invasive alien species. In: UNEP. 2006. Africa Environment Outlook 2: Our environment, our wealth. United Nations Environment Programme, Nairobi. Available online at: http://www.unep.org/DEWA/Africa/docs/en/AEO2_Our_Environ_Our_Wealth.pdf [Accessed on the 20 January 2009].

Chmura, G.L., Anisfeld, S., Cahoon, D., Lynch. J. 2003. Global carbon sequestration in tidal, saline wetland soils. Global Biogeochemical Cycles I7:I-I2.

Chomitz, K.M. 2007. At loggerheads? Agricultural expansion, poverty reduction, and environment in the tropical forests. The International Bank for Reconstruction and Development/The World Bank, Washington.

CIFOR. 2002. Review of forest rehabilitation initiatives - Lessons from the past. Available at: http://www.cifor.cgiar.org/rehab [Accessed I2/05/ro]

Clarke, A. L. and Dalrymple, G. H. 2003. $\$ 7.8$ billion for everglades restoration: Why do environmentalists look so worried? Population and environment 24: 54I-569.

Coleman, H. M., Kanat, G., Aydinol Turkdogan, F. I. 2009. Restoration of the Golden Horn Estuary (Halic). Water Research:43: 4989-5003.

Copeland, B.J. I997. Salt marsh restoration: coastal habitat enhancement. North Carolina Sea Grant Programme, Raleigh.

Costanza et al. 1997. The value of the Worlds ecosystem services and natural capital. Nature 387: 253-260

Costanza R., 2008. Ecosystem Services: Multiple classification systems are needed. Biological Conservation I4I, 350-352.

Crooks, S. and Sharpe, J. 2007. California Dreamin' - lessons in coastal marsh restoration from San Francisco Bay. Defra 42nd Flood and Coastal Management Conference. 03.I.I-03.I.I2. http://www.pwa-ltd.com/documents/CrooksandSharpe_Defra_2007.pdf

Crossman, S.N. et al. 20IO. Reconfiguring an irrigation landscape to im- prove provision of ecosystem services. Ecological economics 69: I03I-I042

Crowley, G et al. 2009. Impact of storm-burning on Melaleuca viridiflora invasion of grasslands and grassy woodlands on Cape York peninsula, Australia. Austral ecology 34: 196-209

Cuyler, C. 1998. Success and failure of reindeer herding in Greenland. Nordic conf of reindeer research, kautokeino I3-I5 March, I998.

Danielsen, Finn, M. K. Sørensen, M. F. Olwig, V. Selvam, F. Parish, N. D. Burgess, T. Hiraishi, V. M. Karunagaran, M. S. Rasmussen, L. B. Hansen, A. Quarto, N. Suryadiputra. 2005. The Asian Tsunami: A Protective Role for Coastal Vegetation. 2005. Science 3I0: 643

De Baets, S. et al. 2009. Methodological framework to select plant species for controlling rill and gully erosion: applictaion to a Mediterranean ecosystem. Earth surface processes and landforms 34: 1374-1392.

Dehghani, M. et al. 20Io. Recreation value of Hara biosphere Reserve using willinges to pay method. International journal of environmental research 4: 27I-280

Descroix, L. et al. 2008. Gully and sheet erosion on subtropical mountain slopes: Their respective roles and the scale effect. Catena 72: 325-339.

Diaz, R.J. and R. Rosenberg. 2008. Spreading dead zones and consequences for marine ecosystems. Science 321:926-928.

Dodds, W. K. et al. 2008. Comparing ecosystem goods and servcies provided by restored and native lands. Bioscience 58: 837-845

Dorrough, J. and Moxham, C. 2005. Eucalypt establishment in agricultural landscapes and implications for landscape-scale restoration. Biological Conservation I23: 55-66.

Dosskey, M. G. et al. 20I0. The role of riparian vegetation in protecting and improving chemical water quality in streams. Journal of the American water resources association 46: 26I-277

Duarte, C.M. (Ed.). 2009. Global Loss of Coastal Habitats: Rates, Causes and Consequences. FBBVA, Madrid. I8I p. ISBN: 978-84-96515-84-0 (avaiable as pdf's at: http://www.fbbva.es/TLFU/tlfu/esp/publicaciones/ libros/fichalibro/index.jsp?codigo=4II).

Duarte, C.M. 2002. The future of seagrass meadows. Environmental Conservation 29: 192-206

Duarte, C.M. et al. 2005b. Dynamics of seagrass stability and change. pp. 27I-294. In: A.W.D. Larkum, R.J. Orth, C.M. Duarte, Seagrasses: Biology, Ecology and Conservation. Springer.

Duarte, C.M. et al. 2009. Will the Oceans Help Feed Humanity? BioScience (in press).

Duarte, C.M., J. Middelburg, and N. Caraco. 2005a. Major role of marine vegetation on the oceanic carbon cycle. Biogeosciences, 2: I-8.

Dudley, N. \& Stolton, S., eds. 2003. Running pure: the importance of forest protected areas to drinking water. Gland, Switzerland, WWF/World Bank Alliance for Forest Conservation and Sustainable Use.

Dzung, H. et al. 2004. The Return of the Limestone Forests: Northeast 
Vietnam, FREC-FIPI and Asia Forest Network, Bohol, Philippines, pp.I-45. EC 2009. Nature's role in climate change: Nature and biodiversity. European Commission Fact Sheet. August 2009.

Eliasch, J. 2008. Climate Change: Financing Global Forests. The Eliasch Review. The Stationary Office Ltd., London.

Eriksson, M. et al. 2009. The Changing Himalayas: Impact of Climate Change on Water Resources and Livelihoods in the Greater Himalayas, ICIMOD

Erwin 2009. Wetlands and global climate change: the role of wetland restoration in a changing world. Wetlands Ecology and Management I7: 7I-84.

FAO. 2005 Helping Forests Take Cover. RAP PUBLICATION 2005/13. http://www.fao.org/docrep/008/aeg45e/aeg45eo5.htm

FAO 200I. Report of the FAO Asia-Pacific Conference on Early Warning, Prevention, Preparedness and Management of Disasters in Food and Agriculture.

FAO. 2003. World agriculture: towards 2015/2030. FAO, Rome. Available online at: ftp://ftp.fao.org/docrep/fao/004/y3557e/y3557e.pdf

Farnsworth N.R. et al. 1985. Medicinal plants in therapy. Bull World Health Organ I985; 63: 965-981.

Fischlin, A. et al. 2007. Ecosystems, their properties, goods and services. In: Parry, M.L., Canziani, O.F., Palutikof, J.P., van der Linden, P.J. \& Hanson, C.E. (eds.), Climate change 2007: Impacts, adaptation and vulnerability. Contribution of Working Group II to the Fourth Assessment Report of the Intergovernmental Panel of Climate Change (IPCC). Cambridge University Press, Cambridge, UK, pp. 2II-272.

Fonseca, M.S. et al.. 2000. Integrating biology and economics in seagrass restoration: How much is enough and why?. Ecological Engineering I5: $227-237$

Forbes, B. et al. 200I. Anthropogenic distrubance and patch dynamics in circumpolar arctic ecosystems. Conservation biology I5: 954-969

Forbes, B. et al. 2009. High resilience in the Yamal-nenets social-ecological system, west Siberian Arctic, Russia. Proc. Of the National Academy of Sciences of the USA 106: 2204I-22048

Frimpong, E. A. et al. 2006. Cost effectiveness of vegetative filter strips and in-stream half-logs for ecological restoration. Journal of American water resources association 42: 1349-I36I

Gallai, N. et al. 2009. Economic valuastion of the vulnerability of world agriculture confronted with pollinator decline. Ecological economics 68: 8IO-82I

Gaston et al. 2003. Rates of species introduction to a remote oceanic island. Proceedings of the Royal Society of London Series B-Biological Sciences 270 (I5I9): IO9I-IO98.

GESAMP (IMO/FAO/UNESCO-IOC/WMO/WHO/IAEA/UN/UNEP Joint Group of Experts on the Scientific Aspects of Marine Environmental Protection) and Advisory Committee on Protection of the Sea. 200I. A sea of troubles. Rep. Stud. GESAMP No. 70, 35 pp.

Global Partnership on Forest Landscape Restoration http://www.ideastransformlandscapes.org/media/uploads/File/FLR\%2opartnership\%2o brochure.pdf

Granek, E. F. et al. 20Io. Ecosystem Services as a Common Language for Coastal Ecosystem-Based Management. Conservation Biology 24(I), 207-2I6.

Green et al. 2005. Sparing land for nature: exploring the potential impact of changes in agricultural yield on the area needed for crop production. Global Change Biology Io (II): I594-I605.

Groombridge, B. and Jenkins, M.D. 2002. World atlas of biodiversity: earth's living resources in the 2Ist century. University of California Press, California, USA.

Hamilton, L.S. and S.C. Snedaker (eds.). I984. Handbook for mangrove area management. East-West Environment and Policy Institute, Honolulu, Hawaii, USA. I23p

Hansen J.E., Sato M., Lacis A., Ruedy R., Tegen I., Matthews E. I998. Climate forcings in the industrial era. Proceedings of the National Academy of Science of the USA 95: I2753-I2758.

Hansen, H., Bachmann, L. and Bakke, T.A. 2003. Mitochondrial DNA variation of Gyrodactylus spp. (Monogenea, Gyrodactylidae) populations infecting Atlantic salmon, grayling and rainbow trout in Norway and Sweden. International Journal for Parasitology 33, I47I-I478.

Harris, J.A. 2006. Ecological Restoration and Global Climate Change. Restoration Ecology I4(2): I7O-I76.

Hemminga, M.A., y C.M. Duarte. 2000. Seagrass Ecology. Cambridge Univ. Press, Cambridge

Herr, D., Galland, G.R. 2009.The Ocean and Climate Change: Tools and Guidelines for Action. IUCN, Gland, Switzerland. 72pp.

Holdich, D.M. et al. 2009. A review of the ever increasing threat to European crayfish from non-indigenous crayfish species. Knowledge and Management of Aquatic Ecosystems II:394-395.

Holl, K. D. and Howarth, R. B. 2000. Paying for restoration. Restortaion ecology 8: 260-267

Horton, M.P. 2009. Establishing the island of Ireland's first ark site for the white-clawed crayfish Austropotamobius pallipes in the Ballinderry river system, Co. Tyrone. In: Brickland, J., Holdich, D.M. and Imhoff, E.M. (eds.), Crayfish Conservation in the British Isles, Proceedings of conference held in Leeds, 87-94.

Hoshino et al. 2009. Effects of abandonment and grazing exclusion on available soil water and other soil properties in a semi-arid Mongolian grassland. Soil and tillage research I05: 228-235.

Hoshino, A. et al. 2009. Effects of crop abandonment and grazing exclusion on available soil water and other soil properties in a semi-arid Mongolian grassland. Soil and tillage research I05: 228-235.

Hu et al. 2008. Impact of land use and land cover changes on ecosystem 
services in Menglun, Xishuangbanna, Southwest China. Environmental monitoring and assessment 146: 147 -156.

Hu, H. B. et al. 2008. Impact of land use and land cover changes on ecosystem services in Menglun, Xishuangbanna, Southwest China. Environmenatl monitoring and assessment I46: $147-156$.

Ibanez et al. 2007. Desertification due to overgrazing in a dynamic commercial livestock-grass-soil system. Ecological modelling 205: 277-288.

ICIMOD 2009. Local Responses to Too Much and Too Little Water in the Greater Himalayan Region. International Center for Integrated Mountain Development, Kathmandu, Nepal.

ICRI. 2005. ICRI Resolution on Artificial Coral Reef Restoration and Rehabilitation. http://www.icriforum.org/sites/default/files/ICRI_resolution_Restoration.pdf [Accessed May 20I0]

IFPRI. 2007. The World Food Situation: New Driving Forces and Required Actions. IFPRI, Washington D.C. Available online at: http://www. ifpri.org/pubs/fpr/pri8.pdf [Accessed on the 20 January 2009].

Ingraham, M. W. and foster, S. G. 2008. The value of ecosystem services provided by the US national Wildlife Refuge System in the contiguous US. Ecological economics 4: 608-6I8.

Instituto Terra 2007. Restoration of the Atlantic Forest (Mata Atlântica). Available at: www.institutoterra.org/index.htm and www.globalrestorationnetwork.org [Accessed Io/05/I0].

IPCC 200I. Climate Change 200I: Synthesis Report. Contribution of Working Groups I, II, and III to the Third Assessment. Report of the Intergovernmental Panel on Climate Change, IPCC, Geneva, Switzerland.

IPCC 2007. Climate Change 2007: Synthesis Report. Contribution of Working Groups I, II, and III to the Fourth Assessment. Report of the Intergovernmental Panel on Climate Change, IPCC, Geneva, Switzerland.

ITTO. 2002. ITTO guidelines for the restoration, management and rehabilitation of degraded and secondary tropical forests. ITTO Policy Development Series No I3. International Tropical Timber Organization. http:// ideastransformlandscapes.org/media/uploads/File/ITTOGuidelines.pdf

IUCN. 2008. Red list of threatened species. IUCN, Gland, Switzerland. Available online at: http://www.iucnredlist.org/

Jaffe, R. et al. 20IO. Estimating the density of honeybee colonies across their natural range to fill the gap in pollinator decline censuses. Conservation Biology 24: 583-593

James, A. N. et al. 200I. Can we afford to conserve biodiversity? BioScience 51: 43-52.

Jianchu, X. et al. 2007. The Melting Himalayas. Regional Challenges and Local Impacts of Climate Change on Mountain Ecosystems and Livelihoods. ICIMOD Technical Paper.

Johnsen, B.O. and A.J. Jensen 1986. Infestations of Atlantic salmon (Salmo salar) by Gyrodactylus salaris, in Norwegian rivers. - J. Fish Biol. 29, 233-24I.
Johnsen, B.O. and Jensen, A.J. 2003. Gyrodactylus salaris in Norwegian waters. In: Atlantic Salmon: Biology, Conservation and Restoration, pp. 38 44. Petrozavodsk: Russian Academy of Sciences, Karelian Research Center, Institute of Biology.

Johnsen, M. D., et al. 20Io. Pest reduction services by birds in shade and sun coffee in Jamaica. Animal Conservation: I3: I4O-I47

Kaimowitz, D. 2003. Forests and Rural Livelihoods in Sub Saharan Africa, pp.45-65. In Okansanen, T., B. Pajari and T. Toumasjjukka (eds.) Forests in Poverty Reduction Strategies: Capturing the Potential, EFI Proceedings No.47, 2003. Tuusla European Forest Institute.

Keller, A.A., Goldstein, R.A. I998. Impact of carbon storage through restoration of drylands on the global carbon cycle. Environmental Management 22: 757-766.

Kenis et al. 2009. Ecological effects of invasive alien insects. Biological Invasions II (I): 2I-45.

King, S. L. et al. 2009. The ecology, restoration and management of siutheastern floodplain ecosystems: A synthesis. Wetlands 29: 624-634

Klein, D. R. 1980. Conflicts between domestic reindeer and their wild counterparts: A review of Euroasian and North American experience. Arctic 33: $739-756$

Ko, J. Y. et al. 2004. A comparative evaluation of money-based and energy-based cost-benefit analyes of tertiary municipal wastewater treatment using forested wetlands versus sand filatration in Louisiana. Ecological economics 49: 33I-347

Kremen C. and R. Chaplin. 2007. Insects as providers of ecosystem services: crop pollination and pest control. In Insect Conservation Biology: proceedings of the Royal Entomological Society's 23rd Symposium. (Stewart, A.J.A., New, T.R. and Lewis, O.T. (eds)) CABI Publishing, Wallingford, 349-382.

Laffoley, D., Grimsditch, G. (eds). 2009. The management of natural coastal carbon sinks. IUCN, Gland, Switzerland. 53 pp.

Lal, R. 2004. Soil Carbon Sequestration Impacts on Global Climate Change and Food Security. Science 304: I623-1627.

Lal, R. 2008. Carbon Sequestration. Philosophical Transactions of the Royal Society B 363: 815-830.

Lal, R. 2009a. Soil Carbon Sequestration through Desertification Control. In: Bigas, H., Gudbrandsson, G.I., Montanarella, L., Arnalds, A. (eds) Soils, Society \& Global Change: Celebrating the Centenary of Conservation and Restoration of Soil Vegetation in Iceland. 3I August - 4 September 2007, Selfoss, Iceland. Proceedings of the International Forum: II2-I22.

Lal, R. 2009b. Soils and food sufficiency: A review. Agronomy and sustainable development I: II3-I33.

Le Maitre et al. 2004. Alien plant invasions in South Africa: driving forces and the human dimension. South African Journal of Science Ioo (I), IO3-II2. 
Lee, D. J. and Bwenge, A. 2009. Economic value of ecosystem restoration in Biscayne Bay, Florida.

Lewis, R. 200I. Mangrove restoration-costs and benefits of successful ecological restoration. Proc. Of the mangrove valuation workshop, 4-8th April, 200I,Penang.

Lewis, R. 2005. Ecological engineering for successful management and restoration of mangrove forests.

Li, X. R. et al. 2009. Pattern sof shrub species richness and abundance in relation to environmental factors on the Alxa plateau: prerequisites for conserving shrub diversity nin extreme arid desert regions. Science in china Series 52: 669-680.

Lindenmayer, D.B., Steffen, W., Burbidge, A.A., Hughes, L., Kitching, R.L., Musgrave, W., Stafford Smith, M. And Werner, P.A. (in Press) Conservation strategies in response to rapid climate change: Australia as a case study. Biological Conservation

Lodge D.M. et al. 2000. Non-indigenous crayfishes threaten North American freshwater biodiversity. Fisheries, 25, 8, 7-20.

Lovich, J. E. and Bainbridge, D. 1999. Anthropogenics degradation of the Southern California desert ecosystem and prospects for natural recovery and restoration. Environmental management 24: 309-329

Lowery R. S. and Holdich D. M. I988. Pacifastacus leniusculus in North America and Europe, with details of the distribution of introduced and native crayfish species in Europe, in Holdich D. M. and Lowery R. S. (Eds), Freshwater crayfish: biology, management and exploitation. Croom Helm, London: 283-308.

Macdonald, I. A. W. I994. Global change and alien invasion, implications for biodiversity and protected area management. In: Biodiversity and global change. O. T. Solbrig, P. G. van Emden and W. J. van Oordt (ed.). Wallingford-Oxon, UK. CAB International.

Mack et al. 2000. Biotic Invasions: causes epidemiology, global consequences and control. Ecological Applications io (3): 689-710.

Malcolm et al. 2002. Estimated migration rates under scenarios of global climate change. Journal of Biogeography 29 (7): 835-849.

Maloti Drakensberg Transfrontier Project. 2007. Payment for Ecosystem Services: Developing an Ecosystem Services Trading Model for the Mnweni/Cathedral Peak and Eastern Cape Drakensberg Areas. Mander (Ed) INR Report IR28I. Development Bank of Southern Africa, Department of Water Affairs and Forestry, Department of Environment Affairs and Tourism, Ezemvelo KZN Wildlife, South Africa. Available at: http://www.futureworks.co.za/PES\%2oFINAL\%2oREPORT\%2o6\%20MARCH\%2008. pdf [Accessed I0/05/10].

Masood, E. 2005 Biodiversity loss 'poses grave threat to human health' sciencedev.net http://www.scidev.net/en/agriculture-and-environment/ news/biodiversity-loss-poses-grave-threat-to-human-hea.html (accessed May 2010)
McKinsey, 2008 (See TEEB, 2009)

Melana, D.M. et al. 2000. Mangrove Management Handbook. department of Environment and Natural Resources, Manila, Philippines, Coastal Resource Project, Cebú City, The Philippines, 96 p.

Miles, L. 20IO. Implications of the REDD negotiations for forest restoration. v2. UNEP World Conservation Monitoring Centre, Cambridge.

Millennium Ecosystem Assessment. 2005. Ecosystems and Human Wellbeing: Biodiversity Synthesis. World Resources Institute, Washington. D.C

Monela, G.et al. 2004. A Study on the Social, Economic and Environmental Impacts of Forest Landscape Restoration in Shinyanga Region, Tanzania (The United Republic of Tanzania Ministry of Natural Resources and Tourism, Forestry, and Beekeeping Division, Dar es Salaam, Tanzania, and IUCN, The World Conservation Union, Eastern Africa Regional Office, Nairobi, Kenya.

Mooney, H.A. and Hobbs, R.J. (ed.). 2000. Invasive Species in a Changing World. Island Press. Washington, D.C.

Nellemann, C. et al. 2003. Progressive impacts of piecemeal development on wild reindeer. Biological Conservation II3: 307-317.

Nellemann, C., Corcoran, E., Duarte, C. M., Valdés, L., De Young, C., Fonseca, L., Grimsditch, G. (Eds). 2009a. Blue Carbon. A Rapid Response Assessment. United Nations Environment Programme, GRID-Arendal, www.grida.no

Nellemann, C. et al. 2009b. Effects of recreational cabins, trails and their removal for restoration of reindeer winter ranges. Restoration Ecology I-9

Nepstad, D. C. et al. 2007. Mortality of large trees and lianas following experimental drought in an amazon forest. Ecology 88: 2259-2269

O'Donell, T. K. et al. 2007. River enhancement in the upper Missipi river basin: Approaches base don river uses, alterations and management agencies. Restoration ecology I5: 538-549

Ong, J.E. I993. Mangroves - A carbon source and sink. Chemosphere 27: I097-IIO7.

Pabon-Zamora, L. et al. 2008. Protected areas and human well-being: Experiences from Indonesia, Mexico, Peru and Venezuela'. In: Protected Areas in Today's World: Their Values and Benefits for the Welfare of the Planet, pp.67-76. Secretariat of Convention on Biological Diversity Technical Series no. 36 , Montreal. Online at: http://www.cbd.int/doc/publications/cbd-ts-36-en

Pacific Disaster Center 2009. www.pdc.org Updates and statistics on natural hazards and disasters in the Asia-Pacific region.

Parish, F. et al. (eds). 2008. Assessment on peatlands, biodiversity and climate change: main report. Global Environment Centre, Kuala Lumpur and Wetlands International, Wageningen. I79 pp.

Pearce, D. 2007. Do we really care about biodiversity? Environmental and resource economics 37: 313-333

Perrot-Maître D and Davis P. 200I, "Case Studies: Developing Markets 
for Water Services from Forests" Washington D.C., Forest Trends, Washington DC, 37 .

Pimentel et al. 200I. Economic and environmental threats of alien plant, animal and microbe invasions. Agriculture, Ecosystems and Environment 84 (I): I-20.

Pimentel et al. 2005. Update on the environmental and economic costs associated with alien-invasive species in the United States. Ecological Economics 52 (3): 273-288.

Pimentel, D. (ed.) 2002. Biological Invasions: Economic and Environmental Costs of Alien Plant, Animal, and Microbe Species. CRC Press, Boca Raton, Florida.

Pitman, A.J.,et al. 2004. Impact of land cover change on climate of southwest Western Australia. Journal of Geophysical Research Io9: Di8Io9

Poffenberger, N., 2006. People in the forest: community forestry experiences from Southeast Asia. International Journal Environment and Sustainable Development, Vol. 5, No. I, pg. 57. Available at: http://www. communityforestryinternational.org/publications/articles/People_in_the_ Forest.pdf [Accessed 10/05/10].

Rabalais, N.N. et al. I999. Hypoxia in the northern Gulf of Mexico: Linkages with the Mississippi River, p 297-322 in: Kumpf, H., Steidinger, K. and Sherman, K. (eds), The Gulf of Mexico Large Marine Ecosystem - Assessment, Sustainability and Management. Blackwell Science, U.S.

Reid, P.C. et al. 2009. Impacts of the Oceans on Climate Change. In: D. W. Sims (ed) Advances in Marine Biology, Vol. 56, Burlington: Academic Press. I50 pp.

Romero J, et al. I994. The belowground organs of the Mediterranean seagrass Posidonia oceanica as a biogeochemical sink. Aquatic Botany 47: I3-I9.

Sala et al. 2000. Global biodiversity scenarios for the year 2100. Science 287 (5459): I770-I774.

Sandhu, H. S., et al., 2010. Organic agriculture and ecosystem services. Environmental science and policy I3: I-7.

Sayer, J. et al. 2004. The restoration of forest biodiversity and ecological values. Forest Ecology and Management 2OI (2004) 3-II.

Sayer, J., et al. 2003. Forest landscape restoration: the role of forest restoration in achieving multifunctional landscapes. FAO. Rome.

Schröter, D. et al. 2005. Ecosystem service supply and vulnerability to global change in Europe. Science 310: 1333-1337

Seitzinger, S. and Lee, R. 2008. Land-based sources of nutrients to Large Marine Ecosystems. P. 8I- 97, in Sherman, K. and Hempel, G. (Eds). The UNEP Large Marine Ecosystem Report: A perspective on changing conditions in LMEs of the world's Regional Seas. UNEP Regional Seas Report and Studies No. I82. United Nations Environment Programme. Nairobi, Kenya

Sherman, K. and Hempel, G. 2008. Perspectives on Regional Seas and the Large Marine Ecosystem Approach. P. 3- 2I in Sherman, K. and Hempel, G. (Eds), The UNEP Large Marine Ecosystem Report: A perspective on changing conditions in LMEs of the world's Regional Seas. UNEP Regional Seas Report and Studies No. I82. United Nations Environment Programme. Nairobi, Kenya.

Sibley, P.,et al. 2007. Translocating the white-clawed crayfish Austropotamobius pallipes. In: Hickley, P. and Axford, S. (eds.), Fisheries \& Conservation Successes \& Failures, Institute of Fisheries Management Conference Proceedings, 42-5I.

Simenstad, S. et al. 2006. When is restoration not? Incorporating landscape-scale processes to restore self-sustaining ecosystems in coastal wetland restoration. Ecological Engineering 26, 27-39.

Smith, L. et al. 2010. Effectiveness of eriophyid mites for biological control of weedy plants and challenges for future research. Experimental and applied ecology 5I: II5-I49

Society for Ecological Restoration International (SER) Science \& Policy Working Group. 2005. Guidelines for Developing and Managing Ecological Restoration Projects, 2nd Edition. www.ser.org \& Tucson: Society for Ecological Restoration International.

Society for Ecological Restoration International (SER) Science and Policy Working Group. 2004. The SER International Primer on Ecological Restoration. www.ser.org \& Tucson: Society for Ecological Restoration International.

Society for Ecological Restoration International (SER) Science and Policy Working Group. 2007. Ecological Restoration as a Tool for Mitigating and Adapting to Climate Change. Policy Position Statement, www.ser.org \& Tucson: Society for Ecological Restoration International.

Society for Ecological Restoration International (SER) Science and Policy Working Group. 20I0. CBD Information Note for SBSTTA I4, www.ser.org \& Tucson: Society for Ecological Restoration International.

Society for Ecological Restoration International 2009. Case study - Indonesia: Central Kalimantan Peatlands Restoration Project. http://www. globalrestorationnetwork.org/database/case-study/?id=252. Retrieved 7/05/2010.

Söderhäll, K. \& Cerenius, L. I999. The crayfish plague fungus: History and recent advances. Freshwater Crayfish I2: II-35.

Sodhi, N. S. et al. 2010. Local people value environmental services provided by forested parks. Biodiversity and conservation I9: II75-II88

Sommerkorn, M., Hassol, S.J. 2009. Arctic Climate Feedbacks: Global Implications. WWF International Arctic Programme, Oslo.

Song et al. 2008. Different responses of invasive and native species to elevated $\mathrm{CO}_{2}$ concentration. Acta Oecolo 35 (I): I28-I35.

Stehfest, E. Et al. 2009. Climate benefits of changing diet. Climatic Change 95:83-102

$\mathrm{Su}, \mathrm{Y}$. Z.,et al. 2005. Influences of continuous grazing on soil properties in a degraded sandy grassland, Inner Mongolia, Northern China. Catena 59: $267-278$ 
Svärdson, G. 1995. Early history of signal crayfish introduction into Europe. Freshwater Crayfish 8: 68-77.

Tallis, H. et al. 2008. Linking terrestrial and marine conservation planning and threats analysis. Conservation biology 22: I20-130

Taugbøl, T. \& Skurdal, J. I999. The future of crayfish in Europe: How to make the best of a bad situation? In: Gherardi, F. and Holdich, D.M. (eds.), Crayfish in Europe as alien species - how to make the best of a bad situation?, A.A. Balkema, Rotterdam, 27I-279.

Taylor, C. A. 2002. Taxonomy and conservation of native crayfish stocks. I: Holdich, D. M. (ed), Biology of freshwater crayfish, Blackwell science, Oxford, 236-257.

TEEB - The Economics of Ecosystems and Biodiversity for National and International Policy Makers. 2009. Chapter 9: Investing in ecological infrastructure. Available at: http://www.teebweb.org/LinkClick.aspx?filetick et $=9 \mathrm{NUqttj}$ b3b\% $3 \mathrm{~d} \&$ tabid=IOI9\&language=en-US [Accessed I0/05/10].

TEEB. 2008. The economics of ecosystems and biodiversity. Available at: http://www.cbd.int/iyb/doc/prints/teeb-en.pdf [Accessed Io/05/Io].

Thompson, R.D. I998. Atmospheric Processes and Systems. Routledge introductions to environment series. Routledge, London.

Tilman, D et al. 2002. Forecasting agriculturally driven global environmental change. Science 292: 28I-284

Ting, A. S. Y. et al. 20I0. Induction of host defence enzymes by the endophytic bacterium Serratia marcescens in Banana plantlets. International journal of pest management 56: I83-I88.

Tipper, R. (no date) Chiapas, Mexico. Global Partnership on Forest Landscape Restoration: Investing in People and Nature. http://www.unep-wcmc.org/forest/restoration/globalpartnership/docs/Mexico.pdf. Retrieved 04/05/10.

Todokoro, Y. and Isobe, K. 20IO. Effectiveness of predatory mites Neoseiulus womersleyi proliferated on natural enemy preservation plants in suppressing population density of Kanzawa spider mite, Tetranychus kanzawai kishida on Tea. Japanese journal of applied entomology and zoology 54: I-I2.

Tri, N.H., Adger, W.N., Kelly, P.M. I998. Natural resource management in mitigating climate impacts: the example of mangrove restoration in Vietnam. Global Environmental Change 8: 49-6r.

Tscharntke, $\mathrm{T}$ et al. 2007. Conservation biological control and enemy diversity on a landscape scale. Biological control 43: 294-309.

Turner, R. E. and Rabalais, N. N. I99I. Changes in Mississippi River water quality this century. Implications for coastal food webs. BioScience (4I): I4O-I48.

UN Population Division, 2007. United Nations, Department of Economic and Social Affairs, Population Division. World Urbanization Prospects: The 2007 Revision. CD-ROM Edition - Data in digital form (POP/ DB/ WUP/Rev.2007
UNDESA. 2009. Millennium development goals report 2009. New York, United Nations Department of Economic and Social Affairs.

UNDP. 2006. United Nations Development Programme, Human Development Report 2006. UNDP, New York. Available online at: http://hdr. undp.org/en/reports/global/hdr20o6/. [Accessed May 20I0]

UNEP 2005. Fall of the Water. UNEP/GRID-Arendal, Arendal, Norway. Available online at: http://www.grida.no/_documents/himalreport_scr.pdf [Accessed on the 20 January 2009].

UNEP. 200I. GLOBIO. Global methodology for mapping human impacts on the biosphere. UNEP/DEWA/TR.oI-3. Available online at: http:// www.globio.info/download.cfm?File=region/polar/globioreporthires.pdf [Accessed on the 20 January 2009].

UNEP. 2004. The GEO-3 Scenarios 2002-2032 Quantification and Analysis of Environmental Impacts. UNEP/RIVM Bilthoven, Netherlands. Available online at: http://www.rivm.nl/bibliotheek/rapporten/40200I022. html [Accessed on the 20 January 2009].

UNEP. 2007 . The Global Environment Outlook Report. UNEP, Nairobi. Available online at: http://www.unep.org/geo/geo4/report/GEO-4_Report_Full_en.pdf [Accessed on the 20 January 2009].

UNEP. 2007. Global Outlook for Snow and Ice. UNEP, Nairobi. Available online at: http://www.unep.org/geo/geo_ice/PDF/full_report_LowRes.pdf [Accessed on the 20 January 2009].

UNEP. 2008. In Dead Water. Merging of Climate Change With Pollution, Over-Harvest, and Infestations in the World's Fishing Grounds. UNEP/GRID-Arendal, Arendal, Norway. Available online at: http://www. grida.no/_res/site/file/publications/InDeadWater_LR.pdf [Accessed on the 20 January 2009].

UNEP. 2009. The environmental food crisis: Can we feed the the Commonwealth without a Green Economy. The Commonwealth Ministers Reference Book 2009

UNEP. 20I0a. Sick water? The central role of wastewater management in sustainable development UNEP/GRID-Arendal, Arendal, Norway. Available online at: http://grida.no/publications/rr/sickwater/

UNEP 20Iob. The Last Stand of the Gorilla - Environmental Crime and Confict in the Congo Basin. UNEP/GRID-Arendal, Arendal, Norway. Available online at: http://grida.no/publications/rr/gorilla/

UNEP-WCMC, 2004. The cloud forest agenda report. www.unep-wcmc.org

UNEP-WCMC. 20Io. World Database on Protected Areas. http://www. wdpa.org/ (accessed May 20Iо)

Unestam, T. I972. On the host range and origin of the crayfish plague fungus. Rep. Inst. Freshw. Res. Drottningholm 52:192-198.

UN-HABITAT. 20IO. State of the World's Cities 20I0/20II - Cities for All: Bridging the Urban Divide http://www.unhabitat.org/pmss/listItemDetails.aspx?publicationID $=2917$ 
UNU-IAS (United Nations University . Institute of Advanced Studies) 2008. Nepal Climate Change and Secirity Factsheet Series 2008/I.

USAID 2007. South Asia - Regional Floods. Fact Sheet no. 2/2007.

Valiela, I., Bowen, J.L., Cork, J.K. 200I. Mangrove forests: One of the world's. threatened major tropical environments. Bioscience 5I: 807-8I5.

van Wilgen et al. 2007. A biome-scale assessment of the impact of invasive alien plants on ecosystem services in South Africa. Journal of Environmental Management 89 (4): 336-349.

Vieria, D. L. M. Et al. 2009. Agro-successional restoration as a strategy to facilitate tropical forest recovery. Restoration ecology I7: 45I-459

Vilà et al. 2006. Linking plant invasions to environmental change. In: Canadell J., Pataki D. and Pitelka L. (ed.) Terrestrial Ecosystems in a Changing World pp. II5-I24. Springer, Berlin.

Vistnes, I. and Nellemann, C. 2009. Impacts of human activity on reindeer and caribou: The matter of spatial and temporal scales. Polar Biology 3I: 399-407.

Vistnes, I. et al. 2008. Summer distribution of wild reindeer in relation to human actvity and insect stress. Polar Biology 31:I307-I3I7

Vistnes, I. et al. 2004. Effects of infrastructure on migration and range use of wild reindeer. Journal of Wildlife Management 68: IoI-Io8

Walden, C. (no date) http://www.unep-wcmc.org/forest/restoration/ fris/documents/Belize.pdf

Waycott, M. et al. 2009. Accelerating loss of seagrasses across the globe threatens coastal ecosystems. Proceedings of the National Academy of Sciences of the USA (PNAS) Io6: I2377-I238I

Wenhua, L . 2004. Degradation and restoration of forest ecosystems in China. Forest Ecology and Management Volume 20I, Issue I.

Westman K. I995. Introduction of alien crayfish in the development of crayfish fisheries: experiences with signal crayfish (Pacifastacus leniusculus (Dana) in Finland and the impact on the noble crayfish (Astacus astacus (L.)). Freshwater Crayfish io: I-I7.

Westman, K. et al. I990. Status of crayfish stocks, fisheries, diseases and culture in Europe. Finnish Game and Fisheries Research Institute, Report no. 3, Helsinki, Finland.

Whiting, G.J., Chanton, J.P. 200I. Greenhouse gas balance of wetlands: methane emission versus carbon sequestration. Chemical and Physical Meteology 53: 52I-528.

WHO. 2007. The World Health Report. A Safer Future. Global Public Health Security in the 2Ist Century. WHO, Geneva, Switzerland. Available online at: http://www.who.int/whr/2007/whro7_en.pdf [Accessed on the 20 January 2009].

Wilkinson, C. 2008. Status of coral reefs of the world: 2008. Global Coral Reef Monitoring Network and Reef and Rainforest Research Centre, Townsville, Australia $269 \mathrm{p}$

Wilkinson, C., D, et al. 2006. Status of Coral Reefs in tsunami affected countries: 2005. Australian Institute of Marine Sciences. I54p

Wise M, K., et al. 2009. Implications of Limiting $\mathrm{CO}_{2}$ Concentrations for Land Use and Energy. Science 324: II83-II86.

World Disaster Report 2009. International Federation of Red Cross and Red Crescent Societies, Geneva, Switzerland.

World Resources Institute. 2005. World Resources 2005: The Wealth of the Poor - Managing Ecosystems to Fight Poverty. UNEP/ UNDP/WRI/ World Bank, Washington, DC, USA.

WWF International. 2007. Experiences compiled from the WWF network during a study tour of Spain and Portugal, June 2006 http://assets. panda.org/downloads/flrlessonslearntbooklet.pdf

WWF/IUCN. 2000. WWF/IUCN International Workshop on Forest Restoration: July 3-5 2000, Segovia, Spain http://cmsdata.iucn.org/downloads/flr_segovia.pdf

Xiaonana, D. et al. 2008. Primary evaluation of carbon sequestration potential of wetlands in China. Acta Ecologica Sinica 28: 463-469

Zhang et al. 2005. Grassland recovery by protection from grazing in a semi-arid sandy region of northern China. New Zealand journal of agricultural research 48: 277-284

Zhang, W. and Swinton S. M. 2009. Incorporating natural enemies in an economic threshold for dynamically optimal pest management. Ecological modelleing 9-IO: I3I5-I324

Zhang, X. Y., et al. 2007. Ecosystem services and dis-services to agriculture. Ecological economics 64: 253-260

Zhao, B. et al. 2005. Estimation of ecological service values of wetlands in Shanghai, China. Chinese geographical science I5: I5I-I56 


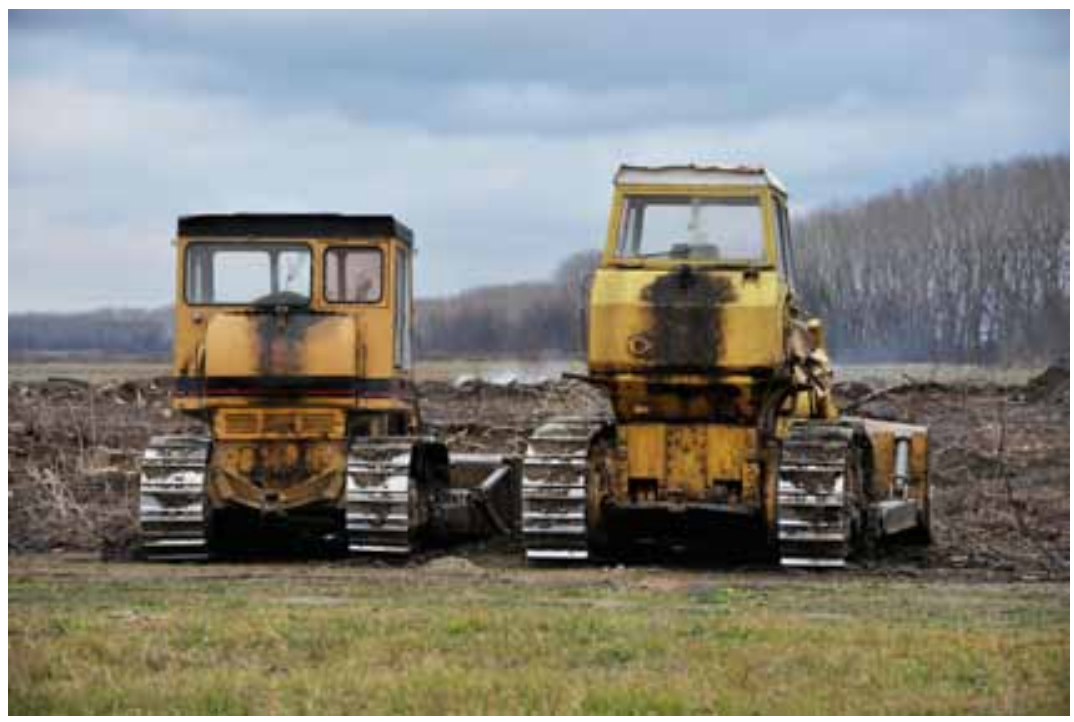





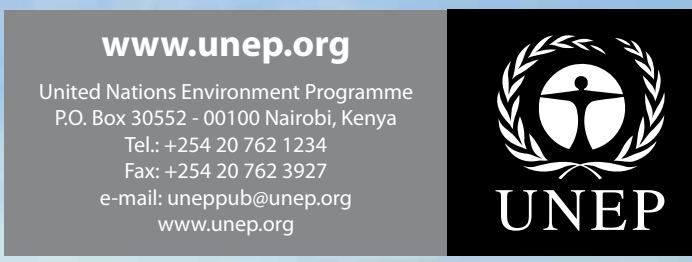

tho chets

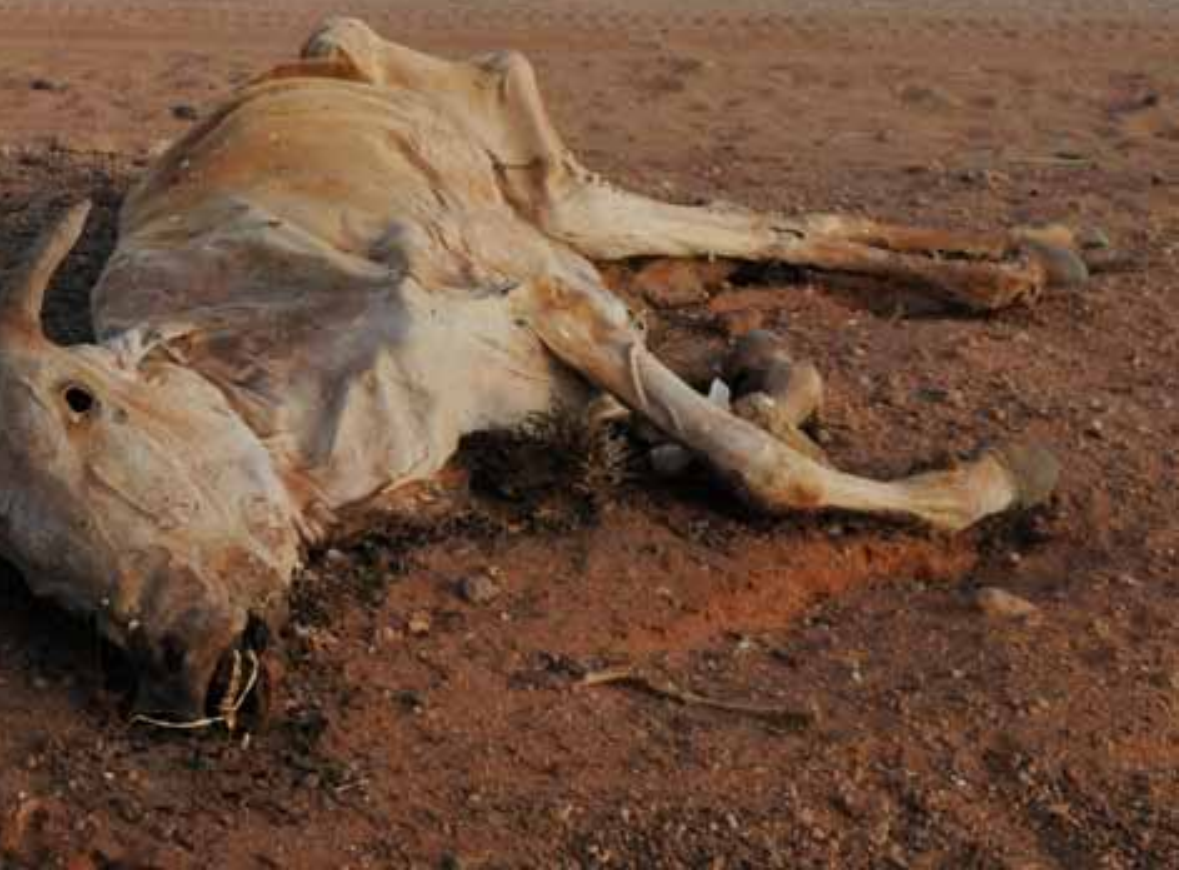

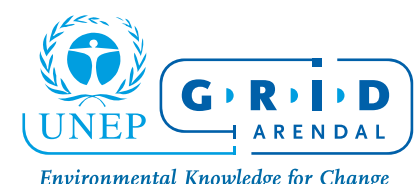

Environmental Knowledge for Change
GRID-Arendal

Teaterplassen 3

N-4836 Arendal

Norway
Phone: +47 47644555

Fax: +47 37035050

grid@grida.no www.grida.no 